\title{
PETROLEUM EXPLORATION PLAYS AND RESOURCE ESTIMATES, 1989, ONSHORE UNITED STATES
}

REGION 1, ALASKA; REGION 2, PACIFIC COAST

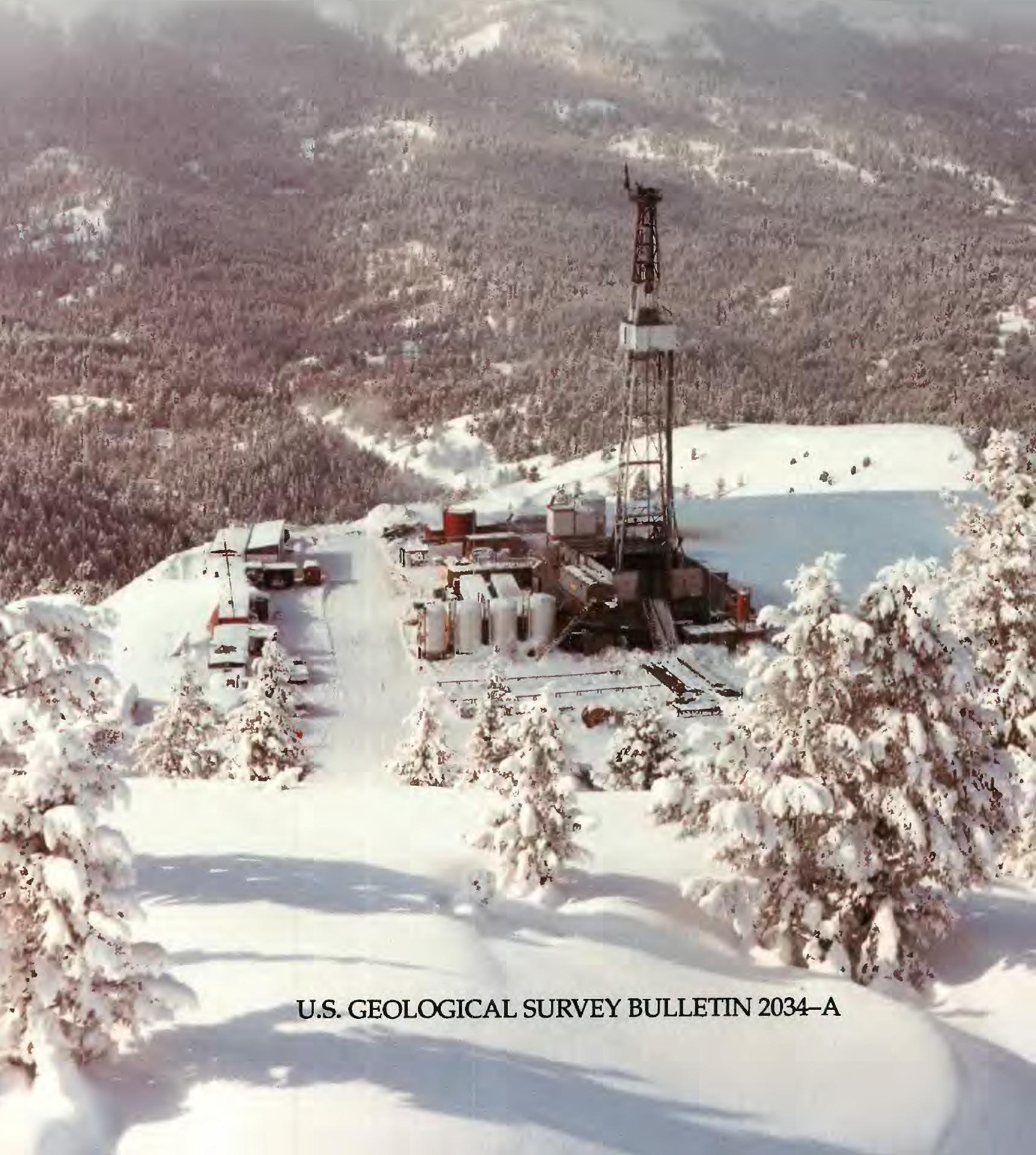


Cover. Amoco Production Company Bald Mountain Unit No. 1, Bonneville County, Idaho; Wyoming Thrust Belt province wildcat. Photograph by Bob Lynn, Amoco Production Company, February 1982. 


\section{Petroleum Exploration Plays and Resource Estimates, 1989, Onshore United States- Region 1, Alaska; Region 2, Pacific Coast}

RICHARD B. POWERS, Editor

U.S. GEOLOGICAL SURVEY BULLETIN 2034-A

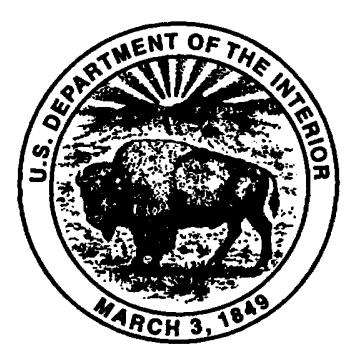

UNITED STATES GOVERNMENT PRINTING OFFICE,WASHINGTON : 1993 


\title{
U.S. DEPARTMENT OF THE INTERIOR BRUCE BABBITT, Secretary
}

\author{
U.S. GEOLOGICAL SURVEY
}

Robert M. Hirsch, Acting Director

\author{
For sale by \\ USGS Map Distribution \\ Box 25286, Building 810 \\ Denver Federal Center \\ Denver, CO 80225
}

\begin{abstract}
Any use of trade, product, or firm names in this publication is for descriptive purposes only and does not imply endorsement by the U.S. Government
\end{abstract}

Library of Congress Cataloging-in-Publication Data

Petroleum exploration plays and resource estimates, 1989, onshore United States / Richard B. Powers, editor.

p. cm. - (U.S. Geological Survey bulletin ; 2034)

Includes bibliographical references.

Contents: ch. A. Region 1, Alaska ; Region 2, Pacific Coast

1. Petroleum-Geology-Alaska. 2. Petroleum-Geology-Pacific Coast

(U.S.) 3. Petroleum reserves-Alaska. 4. Petroleum reserves-Pacific Coast

(U.S.). I. Powers, Richard Blake. II. Series.

QE75.B9 TN870.5

$557.3 \mathrm{~s}-\mathrm{dc} 20$

[553.2'8'09798] 


\section{CONTENTS}

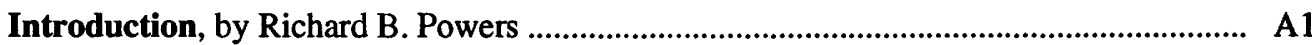

Commodities assessed ............................................................................................ 2

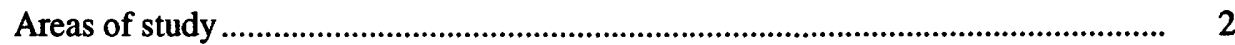

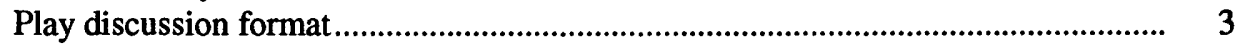

Assessment procedures and methods............................................................................ 3

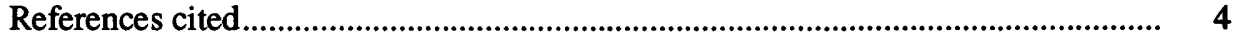

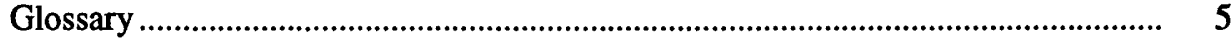

Region 1, Alaska

Geologic framework, by Richard B. Powers ................................................................ 6

Arctic Coastal Plain province (058), by Kenneth J. Bird ............................................ 8

Northern Foothills province (059), by Kenneth J. Bird........................................... 26

Southern Foothills-Brooks Range province (060), by Kenneth J. Bird ..................... 32

Kandik province (061), by Leslie B. Magoon .............................................................. 38

Alaska Interior (062), Kandik (part) (061), Interior Lowlands (063), and Copper River Basin (066) provinces, by Leslie B. Magoon....................... 42

Bristol Basin province (064), by Leslie B. Magoon ................................................ 46

Hope Basin province (065), by Michael A. Fisher .............................................. 50

Cook Inlet province (067), by Leslie B. Magoon....................................................... 52

Alaska Peninsula province (068), by Leslie B. Magoon and Hugh McLean ............. 58

Gulf of Alaska province (069), by Terry R. Bruns.................................................... 60

Kodiak Island province (070), by Michael A. Fisher ............................................. 64

Southeastern Alaska province (071), by Terry R. Bruns ........................................... 66

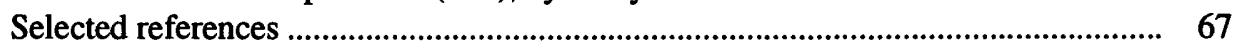

Region 2, Pacific Coast

Geologic framework, by Richard B. Powers.......................................................... 70

Western Oregon-Washington province (072), by Richard G. Stanley ..................... 72

Sacramento Basin province (073), by Larry A. Beyer ............................................. 76

San Joaquin Basin province (074), by Larry A. Beyer ............................................... 84

Los Angeles Basin province (075), by Larry A. Beyer ........................................... 100

Ventura Basin province (076), by Margaret A. Keller ............................................. 108

Santa Maria Basin province (077), by Caroline M. Isaacs ........................................... 114

Central Coastal Basins province (078), by Caroline M. Isaacs ................................... 118

Sonoma-Livermore Basins province (079), by Hugh McLean ..................................... 122

Humboldt Basin province (080), by Hugh McLean ............................................. 126

Eastern Oregon-Washington province (081), by Marilyn E. Tennyson .................... 130

Eastern California province (081A), by Harry E. Cook ............................................. 134

Selected references ….............................................................................................. 136

\section{FIGURES}

\section{Region 1, Alaska}

1. Diagram showing petroleum resource classification

2. Map showing petroleum regions assessed in this study

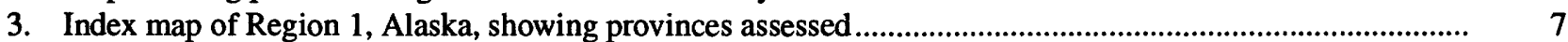

4. Arctic Coastal Plain province (058), generalized stratigraphic column ........................................................... 9

5-12. Play maps:

5. Topset play

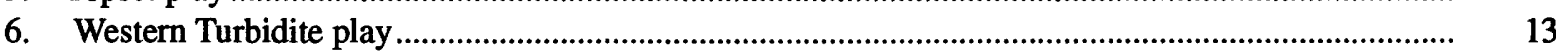




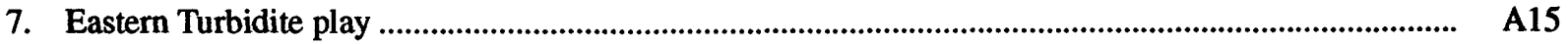

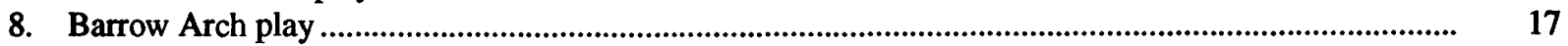

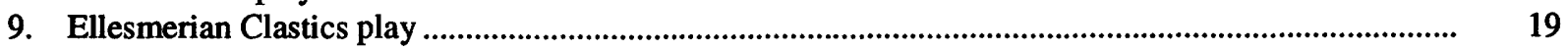

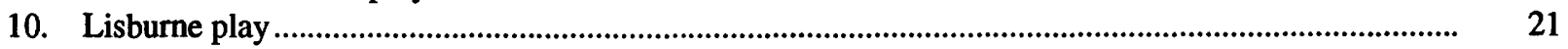

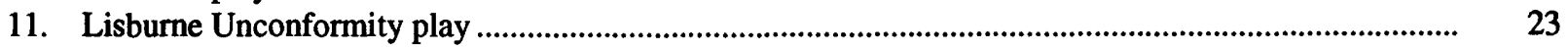

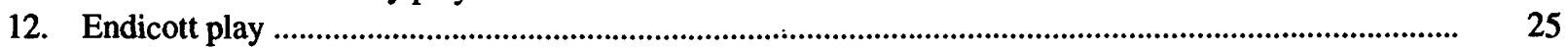

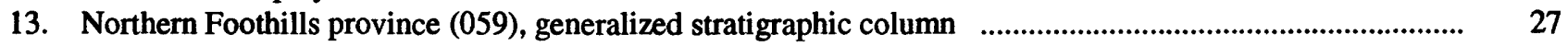

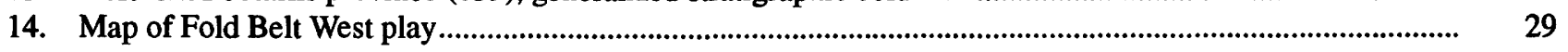

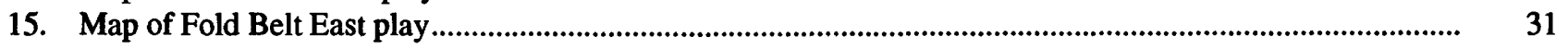

16. Southern Foothills-Brooks Range province (060), generalized stratigraphic column ....................................... 33

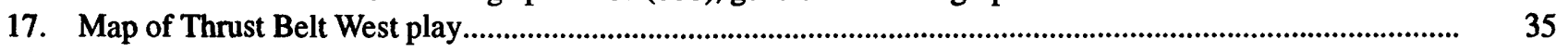

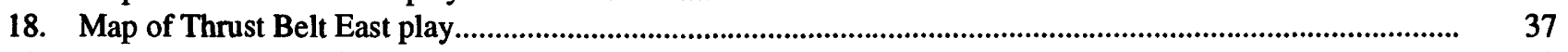

19. Kandik province (061), generalized stratigraphic column ............................................................................... 39

20. Map of Cordilleran Thrust play ....................................................................................................................... 41

21. Alaska Interior (062), Kandik (061) (part), Interior Lowlands (063), and Copper River Basin (066)

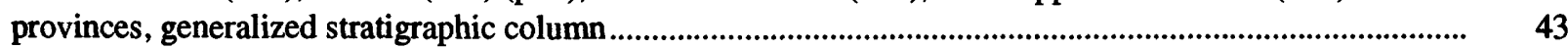

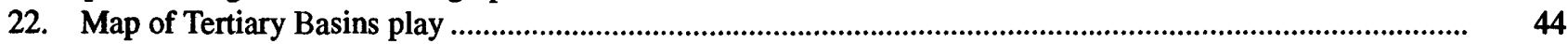

23. Bristol Basin province (064), generalized stratigraphic column ..................................................................... 47

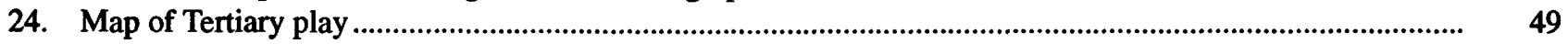

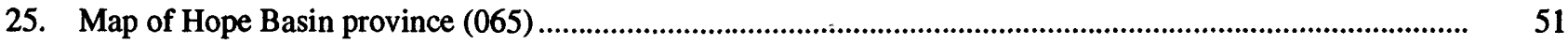

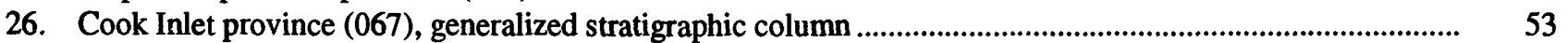

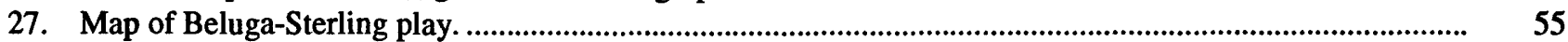

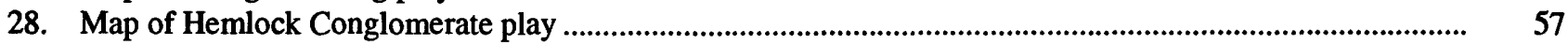

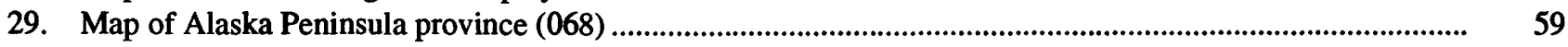

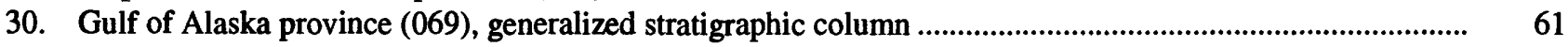

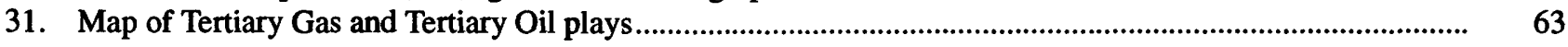

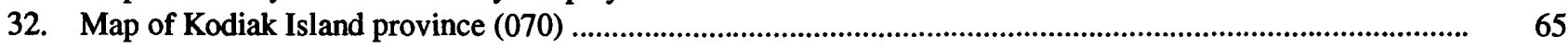

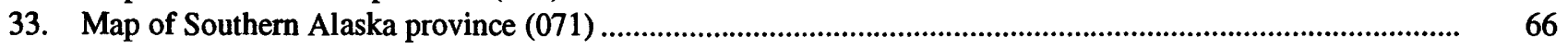

\section{Region 2, Pacific Coast}

34. Index map of lower $\mathbf{4 8}$ States, showing provinces assessed in Region 2.

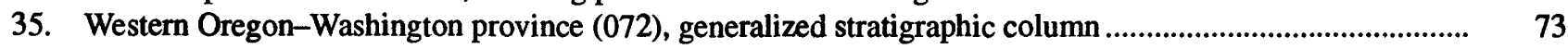

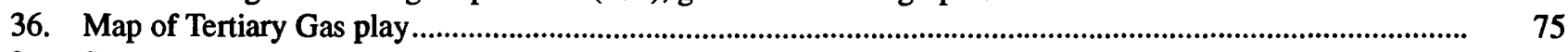

37. Sacramento Basin province (073), generalized stratigraphic column ................................................................. 77

38-40. Play maps:

38. Paleocene-Eocene play

39. Starkey-Winters play

40. Guinda-Kione-Forbes play

41. San Joaquin Basin province (074), generalized stratigraphic column.

42-48. Play maps:

42. Southern Post-Miocene play.

43. Southwest Upper Miocene play.

44. Miocene Fractured Diatomaceous play.

45. Southeast Eocene-Pleistocene play

46. East Pre-Pliocene play.

47. West Pre-Upper Miocene play.

48. Northern Pre-Pliocene play.

49. Los Angeles Basin province (075), generalized stratigraphic column ......................................................... 101

50-52. Play maps:

50. Northwest Shelf play

51. North Flank play.

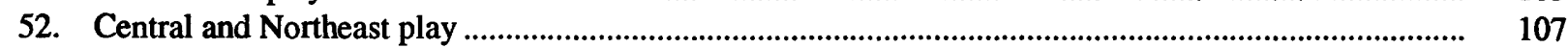

53. Ventura Basin province (076), generalized stratigraphic column............................................................ 109

54. Map of Neogene play . 
55. Map of Paleogene play

56. Santa Maria Basin province (077), generalized stratigraphic column..

57. Map of Neogene play

58. Central Coastal Basins province (078), generalized stratigraphic column ....................................................... 119

59. Map of Neogene play.

60. Sonoma-Livermore Basins province (079), generalized stratigraphic column ............................................. 123

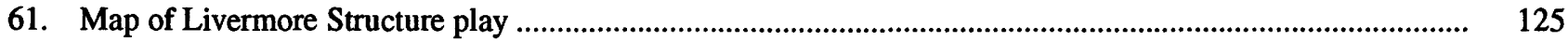

62. Humboldt Basin province (080), generalized stratigraphic column ................................................................ 127

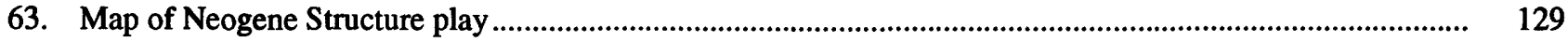

64. Eastern Oregon-Washington province (081), generalized stratigraphic column ........................................... 131

65. Map of Northwestern Columbia Plateau play ....................................................................................

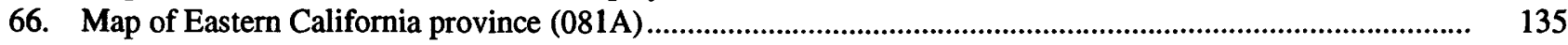

\section{TABLES}

1. Region 1, Alaska-Estimates of undiscovered recoverable conventional oil, gas, and natural gas liquids in onshore provinces and adjacent State waters, by play....

2. Region 2, Pacific Coast-Estimates of undiscovered recoverable conventional oil, gas, and natural gas liquids in onshore provinces and adjacent State waters, by play 


\title{
PETROLEUM EXPLORATION PLAYS AND RESOURCE ESTIMATES, 1989, ONSHORE UNITED STATES-REGION 1, ALASKA; REGION 2, PACIFIC COAST
}

\author{
Richard B. Powers, Editor
}

\section{INTRODUCTION}

\section{By Richard B. Powers}

This study provides brief discussions of the petroleum geology, play descriptions, and resource estimates of 220 individually assessed exploration plays in all 80 onshore geologic provinces within nine assessment regions of the continental United States in 1989; these 80 onshore provinces were assessed in connection with the determination of the Nation's estimated undiscovered resources of oil and gas. The present report covers the 25 provinces that make up Region 1, Alaska, and Region 2, Pacific Coast. It is our intention to issue Region 3, Colorado Plateau and Basin and Range, and Region 4, Rocky Mountains and Northern Great Plains, in book form as well. Regions 5 through 9 (West Texas and Eastern New Mexico, Gulf Coast, Midcontinent, Eastern Interior and Atlantic Coast) will be released individually, as Open-File Reports.

The report is an outgrowth of, and is based on, studies that led to the publication of "Estimates of undiscovered conventional oil and gas resources in the United States-A part of the Nation's energy endowment" (Mast and others, 1989). That report, a cooperative effort by the USGS (U.S. Geological Survey) and MMS (Minerals Management Service), presented estimates of undiscovered conventionally recoverable oil and gas for both the onshore and offshore geologic provinces of the Nation. The data sources, assumptions, and methodologies used in the development of these estimates are summarized in Mast and others (1989) and described in more detail in a joint USGS-MMS Working Paper, U.S. Geological Survey Open-File Report 88-373 (1988). The plays discussed in this present report are those that are located exclusively within the onshore United States and adjoining State offshore areas, as assessed by the USGS. All estimates of undiscovered oil and gas resources are as of January 1,
1987; additional data received after that date were not incorporated into the assessment.

In the 1989 National appraisal of undiscovered oil and gas resources, plays were the basic unit for quantitative estimates; this report presents not only the play estimates, but also the framework and petroleum geology for each of these basic units. Play discussions here summarize the open-file reports which were prepared by the geologists assigned to each assessment area. We are presenting the resource estimates and narrative descriptions at this basic play level because of the great interest shown by the public, State Geological Surveys, the oil and gas industry, and workers involved in oil and gas appraisal.

Sources of information for province studies included published and purchased data, data from USGS studies in progress, data from previous resource assessments, data from State Geological Surveys, and analysis of geological, geochemical, and geophysical data from various sources utilized in developing and defining plays. Computerized drilling and well completion data from oil and gas exploratory and development wells came from PI WHCS (Petroleum Information Corporation's Well History Control System). In addition, data on oil and gas fields were obtained from the "Significant oil and gas fields of the United States" file of NRG Associates, Inc., of 1986, and from the PI PDS (Petroleum Data System) computerized file of 1986. Additional statistical information on field production and reserves was obtained from yearly publications of various State oil and gas commissions, or their equivalents.

Uncertainties are inherent in estimating undiscovered quantities of oil and gas. Play estimates presented here are judgmental and are based upon a variety of geologic data, records of exploration successes and failures, production histories, assumptions of economic and technical conditions, and appraisal methods. Methodologies were developed to aid in making decisions under conditions of 


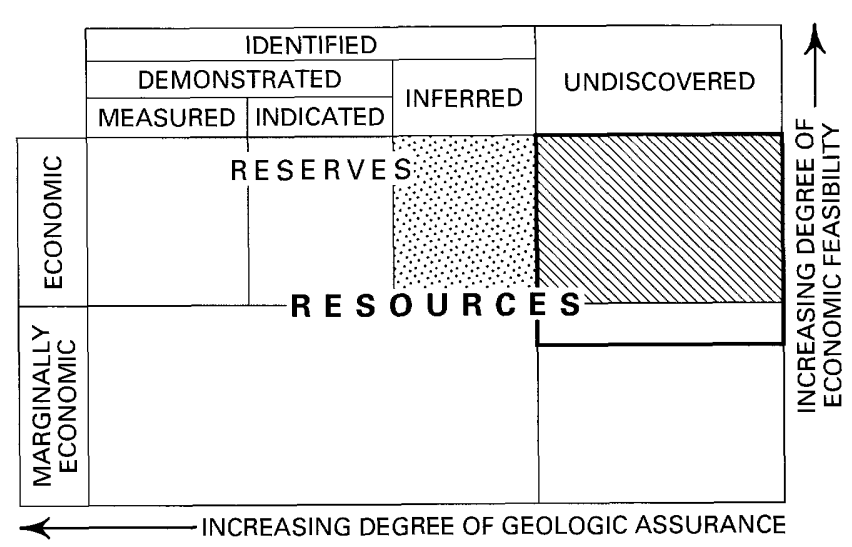

Figure 1. Diagrammatic representation of petroleum resource classification (from Mast and others, 1989) representing conventional oil and gas resources. Area within heavy frame on upper right represents the undiscovered recoverable resources estimated in this study.

uncertainty, and the results are presented as ranges of values with associated probabilities of occurrence. The estimates should be viewed as indicators, not absolutes, of the petroleum potential of the plays. The plays range from those in mature, established producing basins, to highly speculative, frontier-type plays in provinces that have experienced scant exploration or wildcat drilling.

\section{COMMODITIES ASSESSED}

Commodities assessed in this study are crude oil, natural gas, and natural gas liquids that exist in conventional reservoirs. Terms defined here are standard usage of the oil and natural gas industry and of resource estimation.

Undiscovered recoverable resources.-Resources in undiscovered accumulations analogous to those in existing fields which are producible with current recovery technology and efficiency, but without reference to economic viability. These accumulations are considered to be of sufficient size and quality to be amenable to conventional recovery technology. These resources occupy the area of the heavily framed box in figure 1 .

Conventional resources.-Resources included in this category are crude oil, natural gas, and natural gas liquids that exist in reservoirs or in a fluid state amenable to extraction techniques employed in traditional development practices. They occur as discrete accumulations. They do not include oil occurring within extremely viscous and intractable heavy oil deposits, tar deposits, or oil shales, or gas from low-permeability "tight" sandstone and fractured shale reservoirs having in situ permeabilities to gas of less

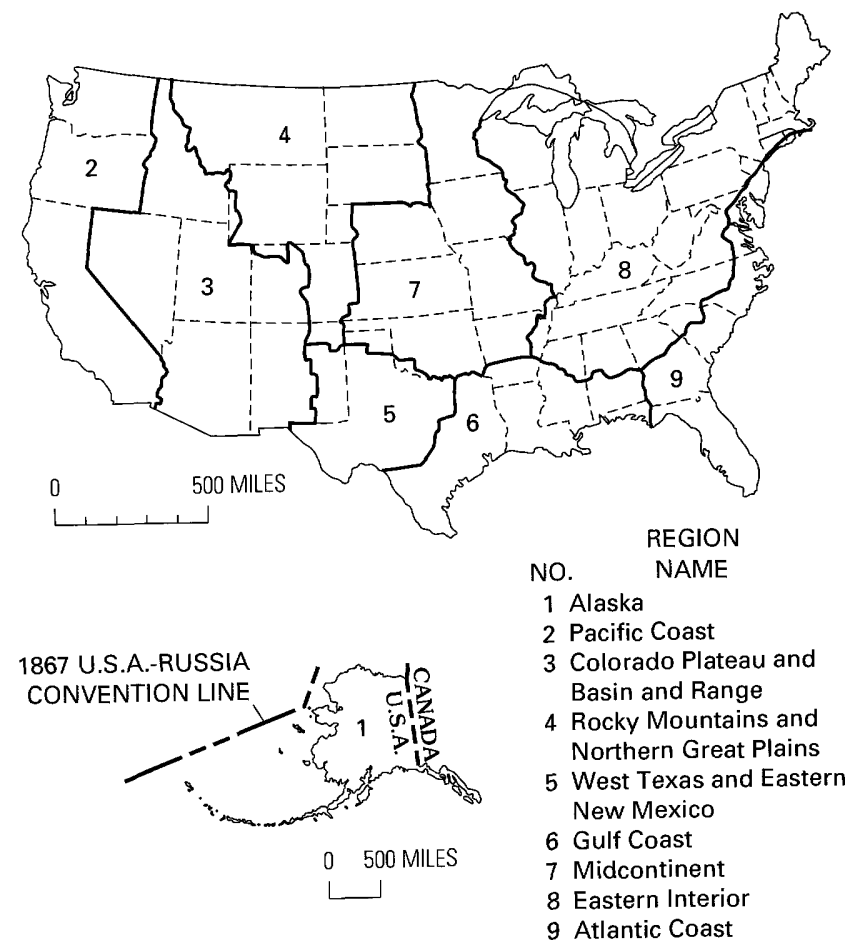

Figure 2. Index map showing petroleum regions assessed in this study. Heavy lines are region boundaries; short-dashed lines are State boundaries.

than 0.1 millidarcy, coal bed methane, gas in geopressured shales and brines, or gas hydrates.

\section{AREAS OF STUDY}

The primary organization of this report is by region (fig. 2); the nine regions described correspond to those in Mast and others (1989). Discussion of each region begins with description of its geologic framework, modified from Mast and others (1989). Discussion of provinces in the region follows; the format for each province includes an introduction covering the geologic setting, exploration history, age of sediments, and a generalized stratigraphic chart. (No stratigraphic chart is provided for a province where no individual plays were assessed; a map of the province is substituted, because no specific stratigraphy is given in that province.) Following each province introduction is systematic discussion of its individual plays. The play format includes the play name, narrative discussion, and two illustrations, (1) a province map with the area of the particular play emphasized, and (2) a tabular form showing the original input data for the play appraisal.

Areas of State but not Federal waters are included in the assessment of adjacent onshore regions and provinces. 
The boundaries of State waters are 3 nautical miles offshore for the Pacific and Atlantic coasts and for the Alabama coast of the Gulf of Mexico. Louisiana and Mississippi have decreed State water boundaries that vary slightly from 3 nautical miles. For the Texas and Florida coasts of the Gulf of Mexico, the boundaries of State waters are 3 marine leagues (10.36 statute miles) offshore. In addition, all maritime boundaries and limits depicted on maps in the report are for initial planning purposes only, and do not prejudice or affect United States jurisdiction in any way.

Regions are basically geographic in character; however, their outlines reflect an attempt to group individual provinces along broad geologic lines. Provinces are constructed around natural geologic entities and may include a single dominant structural element, or a number of contiguous elements; they are named for structural or geographic features within their boundaries. These boundaries, following State and county lines wherever possible, facilitate the use of production, reserve, and other reported data. A play is named after the most dominant feature or characteristic of a structural, stratigraphic, or geographic nature that best identifies it. Its name can also apply to a concept. Many plays described herein are recognized from their titles by the petroleum industry, but play titles are in no way formal geologic or stratigraphic names.

\section{PLAY DISCUSSION FORMAT}

Individual plays described and assessed in this report include only those that were estimated to have undiscovered accumulations greater than $1 \mathrm{MMBO}$ (million barrels of oil) or 6 BCFG (billion cubic feet of gas). Plays judged to have undiscovered accumulations that fell below that threshold were assessed separately for the provinces as a whole, and are not described in the report. A play is defined as a group of geologically related known or undiscovered accumulations and (or) prospects having similar characteristics of hydrocarbon source, reservoir, trap, and geologic history.

In order to achieve some degree of consistency in narrative discussions of a great number and variety of plays, a topical outline based on the definition of an exploration play has been used. Each play discussion notes the play characteristics, followed by descriptions of (1) reservoirs, (2) source rocks and related geochemistry, (3) timing of generation and migration of hydrocarbons, (4) traps (types, sizes, seals, and drilling depths), (5) exploration status (history, discovered volumes, field sizes, and hydrocarbon types), and (6) qualitative future hydrocarbon potential and factors limiting that potential. Although the discussions adhere to the order of the topical outline, it will be apparent that some inconsistency occurs in the amount of detail and coverage of each topic from one play to another. This is due to the relative abundance or lack of data pertinent to each play and is unavoidable in a report of this scope.

Play discussions here are, of necessity, brief summaries. More detailed play information can be found in the province open-file reports, which are listed in the references at the close of each region. The number of individually assessed plays in each province ranges from 1 to as many as 13; however, most provinces contain 3-5 plays. Each play title is followed by a sequence number (for example, Topset Play (020)), and these also appear on the table of resource estimates at the close of each region. Table 1 (Region 1) is on page A68; table 2 (Region 2) is on page A137.

\section{ASSESSMENT PROCEDURES AND METHODS}

Assessments of undiscovered recoverable oil and gas in the individual plays in each province, and resources in small ( $<1 \mathrm{MMBO}$ or $<6 \mathrm{BCFG}$ ) accumulations were based upon review and analysis of the petroleum geology and exploration history of each province that incorporated the most recent geologic and geophysical information available as of January 1, 1987. In the National assessment, 220 plays covering the onshore and State offshore areas were identified, and for each individually assessed play, undiscovered oil and gas resources were estimated. Plays judged to contain more than $1 \mathrm{MMBO}$ or $6 \mathrm{BCFG}$ were individually assessed; plays judged to contain less than those amounts were treated differently, as described following. See Mast and others (1989) and USGS-MMS (1988) for a detailed discussion of this assessment, its assumptions, methods, and results.

In the play analysis method, geologic settings of oil and gas occurrence are modeled. The play is treated as a collection of accumulations (pools, fields) of similar geologic risk sharing common geologic characteristics that include reservoir and source rocks and known or suspected trapping conditions. A team of geoscientists made judgments as to the probability of the occurrence of those geologic factors necessary for the formation of hydrocarbon accumulations, and quantitatively assessed each factor as a geologic attribute of the play; the team then estimated the numbers and sizes of accumulations as probability distributions, conditional on favorable play attributes. All of this information was entered on the play data input form, which is included in each play discussion in this report. A computer program then performed the resource calculations on the basis of the assessment information in the 
input form, employing an analytical method based on probability theory. Final, undiscovered oil and gas estimates for each play, based on this method, are shown on a table of estimates at the end of the discussion for each region.

Probabilistic estimates of recoverable oil and gas in accumulations smaller than the established size cut-off (1 MMBO, 6 BCFG) were made separately. These estimates of small accumulations were based primarily on log-geometric extrapolations of numbers of fields into field-size classes smaller than the cut-offs. Estimates of undiscovered resources for these small fields were made for the province as a whole, rather than for the individual plays. These are shown in the tables of estimates as: Oil <1 MMB and Gas <6BCF. In addition, minor plays and very mature, or nearly depleted plays not assessed individually are included in the tables of estimates as: Other Occurrences $>1 \mathrm{MMBO}$ and Other Occurrences $>6$ BCFG. Ratios of associated-dissolved gas to oil, and NGL (natural gas liquids) to gas, were estimated from historical production data and used for calculation of these components.

\section{REFERENCES CITED}

Mast, R.F., Dolton, G.L., Crovelli, R.A., Root, D.H., Attanasi, E.D., U.S. Geological Survey, and Martin, P.E., Cooke, L.W., Carpenter, G.B., Pecora, W.C., and Rose, M.B., Minerals Management Service, 1989, Estimates of undiscovered conventional oil and gas resources in the United States-A part of the Nation's energy endowment: U.S. Department of the Interior, $44 \mathrm{p}$.

NRG Associates, Inc., 1986, The significant oil and gas fields of the United States (through December 31, 1983): Available from Nehring Associates, Inc., P.O. Box 1655, Colorado Springs, Colorado 80901.

Petroleum Information Corporation, 1986a, Petroleum Data System (through 1985): Available from Petroleum Information Corporation, 4100 East Dry Creek Road, Littleton, Colorado 80122.

1986b, Well History Control System (through December 1985): Available from Petroleum Information Corporation, 4100 East Dry Creek Road, Littleton, Colorado 80122.

USGS-MMS, 1988, Working papers-National assessment of undiscovered conventional oil and gas resources: U.S. Geological Survey Open-File Report 88-373, 511 p. Revised and reissued in microfiche only, July 1989. 


\section{GLOSSARY}

Play. A group of geologically related known or undiscovered accumulations and (or) prospects having similar characteristics of hydrocarbon source, reservoir, trap and geologic history.

Field. A single pool or multiple pools of hydrocarbons grouped on, or related to, a single structural or stratigraphic feature.

Prospect. A geologic feature having the potential for trapping and accumulating hydrocarbons.

Crude oil. A mixture of hydrocarbons present in underground reservoir rocks in a liquid state that remains in a liquid state as it is produced from wells.

Associated gas. Free natural gas, occurring as a gas cap, in contact with and above an oil accumulation within a reservoir.

Dissolved gas. Natural gas dissolved in crude oil within a reservoir.

Nonassociated gas (NA). Natural gas that is neither associated with nor in contact with crude oil within a reservoir.

Natural gas liquids (NGL). Those portions of reservoir gas that are liquified at the surface in lease separators, field facilities, or gas processing plants. NGL is reported only in the tables of estimates in this report.

MMBO. Millions $\left(10^{6}\right)$ of barrels of oil (standard stock tank barrels of crude oil, 42 gallons per barrel).

BBO. Billions $\left(10^{9}\right)$ of barrels of oil.

BOPD. Barrels of oil per day.

BCFG. Billions $\left(10^{9}\right)$ of cubic feet of gas (standard cubic feet of gas at 14.73 pounds per in. ${ }^{2}$ and $60^{\circ} \mathrm{F}$ ). Hydrocarbon gases only.

TCFG. Trillions $\left(10^{12}\right)$ of cubic feet of gas.

MMBOE. Millions of barrels of oil equivalent (conversion factor utilized is $6,000 \mathrm{ft}^{3}$ of gas $=1 \mathrm{BOE}$ ). 


\title{
REGION 1, ALASKA
}

\section{GEOLOGIC FRAMEWORK}

\author{
By Richard B. Powers
}

Region 1 is subdivided into 14 provinces (numbers 058-071) (fig. 3), which contain a total of 19 individually assessed plays; however, 1 play was common to 4 provinces, the Tertiary Basins play, and was treated collectively. In this particular case, the play was included and described in the Alaska Interior Province (062) discussion.

The geology of Region 1 is varied and complex. Much of the region is composed of a mosaic of crustal terranes that have accreted to the ancestral North American cratonic margin. Associated with this mosaic are sedimentary basins, some of which have been strongly deformed and contain altered rocks of little petroleum potential. However, many younger, less deformed basins contain significant potential. The most significant in terms of petroleum are the composite basins, such as the North Slope basin, which encompasses the northern part of the Brooks Range, the Foothills, and the Arctic Coastal Plain, including parts of State offshore waters. Large quantities of oil and gas are present in Triassic reservoirs at Prudhoe Bay field (the largest oil field in North America), Mississippian reservoirs at the Lisburne and Endicott fields, and Cretaceous reservoirs at Kuparuk River field. Significant additional potential is estimated in Paleozoic, Mesozoic, and Tertiary reservoirs in this basin, including the folded and faulted rocks of the northern Brooks Range.

Basins containing nonmarine Cenozoic rocks constitute the most numerous of the Alaskan basins but are poorly known because of extensive alluvial cover. In general, they occupy the interior parts of Alaska. The Cook Inlet basin (067), the best known example, contains large accumulations of oil and gas onshore and in State waters. These basins are characterized by nonmarine fill and are often associated with major faulting. Reservoirs are primarily sandstone units. Most of these basins are considered to be gas prone, and undiscovered resources are estimated to be small.

Basins containing Cenozoic marine rocks are most commonly found on the Bering Shelf and Pacific margins of Alaska. They include the Bristol (064) and Gulf of Alaska (069) basins. Basins of the Pacific margin generally lie in a forearc setting and have accumulated thick sequences of Tertiary marine sediments, and include transported terranes. Significant hydrocarbon accumulations have not yet been discovered in these areas, and the potential appears limited by poor reservoir and source-rock characteristics.

The considerable petroleum potential of onshore Alaska is localized in the North Slope area, concentrated mainly in the Arctic Coastal Plain (058), but also in the Foothills provinces $(059,060)$. Development of future discoveries on the North Slope and elsewhere in onshore Alaska will be dependent on their proximity to the existing pipeline system. 


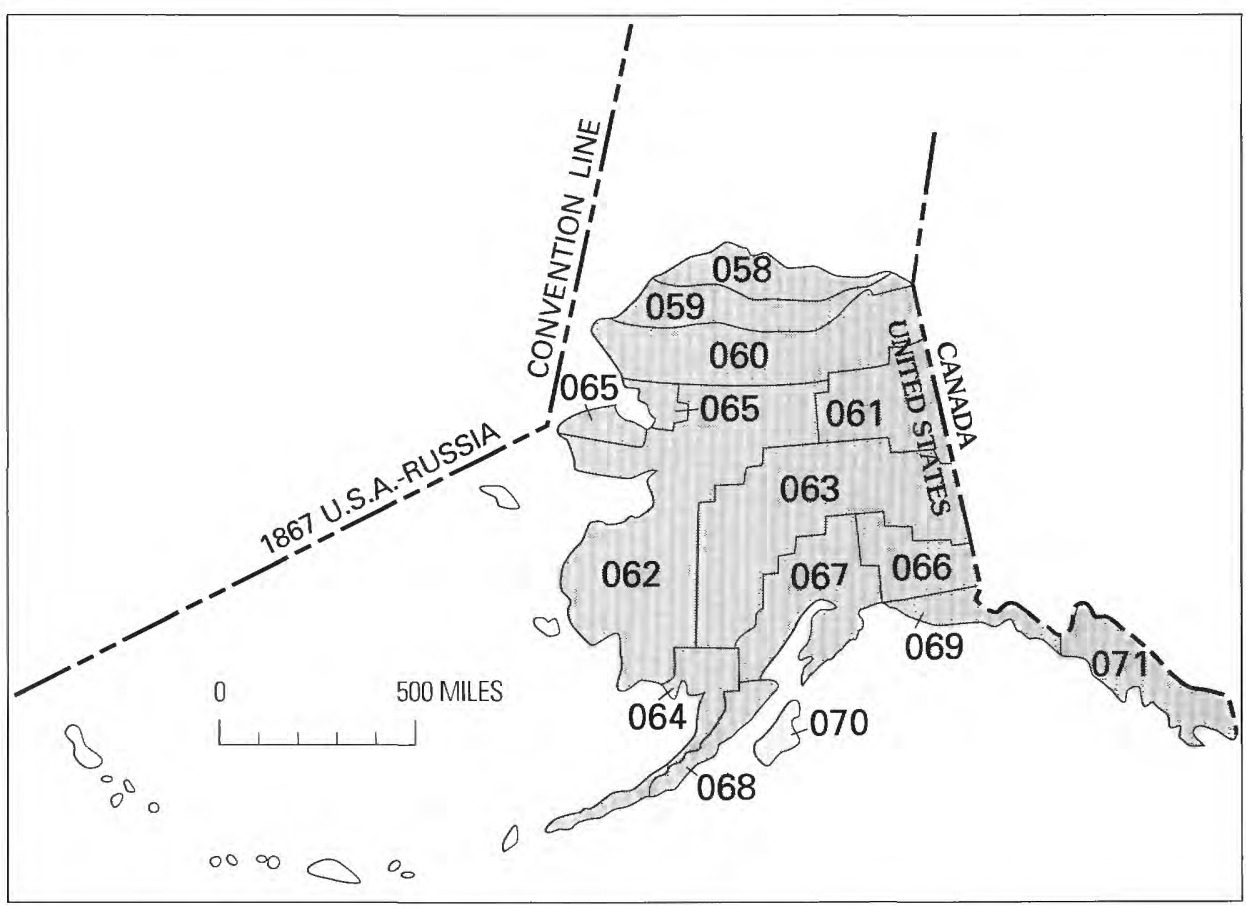

Figure 3. Index map of Region 1, Alaska, showing provinces assessed (shaded). Names of provinces are listed by number in the table of estimates (p. A68). 
ARCTIC COASTAL PLAIN PROVINCE (058)

\author{
By Kenneth J. Bird \\ INTRODUCTION
}

The Arctic Coastal Plain province is the northernmost of the three provinces that make up the Alaskan North Slope. This province extends $500 \mathrm{mi}$ from the Chukchi Sea on the west to near the Canadian border on the east. Its maximum width is about 100 $\mathrm{mi}$. Offshore, the State 3-mile limit forms the seaward boundary of the province. The total area of the province is about $26,000 \mathrm{mi}^{2}$. The North Slope is a Cretaceous and Tertiary foreland basin developed on a Mississippian to Early Cretaceous passive margin (fig. 4). Most of the Arctic Coastal Plain province occupies the undeformed foreland region; in its easternmost part, the Arctic National Wildlife Refuge (ANWR), it includes part of the Brooks Range fold-and-thrust belt. The Arctic Coastal Plain province was the site of the earliest North Slope exploration in large part because of the presence of oil seeps. The first well was drilled near Point Barrow in the National Petroleum Reserve by the U.S. Navy in 1944. Since then more than 200 exploratory wells have been drilled by industry and government on the coastal plain and adjacent State waters. Twenty-four oil and gas accumulations have been found in the province, five of which are commercial. Among these are the Prudhoe Bay and Kuparuk River fields, the two largest producing fields in the United States. The Prudhoe Bay field is the largest in North America with in-place volumes of 23 BBO and 27 TCFG. The province contains more than 95 percent of all discovered North Slope oil and accounts for all current North Slope production; further, it accounts for about 25 percent of total U.S. oil production, about 2 MMBO per day. As of January 1, 1987, cumulative gross oil production was slightly more than 5 billion barrels out of a total ultimate recovery of about 12 billion barrels.

A total of eight plays were defined and individually assessed. These include Topset, Western Turbidite, Eastern Turbidite, Barrow Arch, Ellesmerian Clastics, Lisburne, Lisburne Unconformity, and Endicott. The plays are described in approximate geographic order from north to south and stratigraphically from youngest to oldest. In addition, oil and gas resources were apportioned to the Coastal Plain province on a percentage basis from certain plays in provinces 059 and 060 that cruss province boundaries and extend into the Coastal Plain province. 
REGION 1, ALASKA; REGION 2, PACIFIC COAST

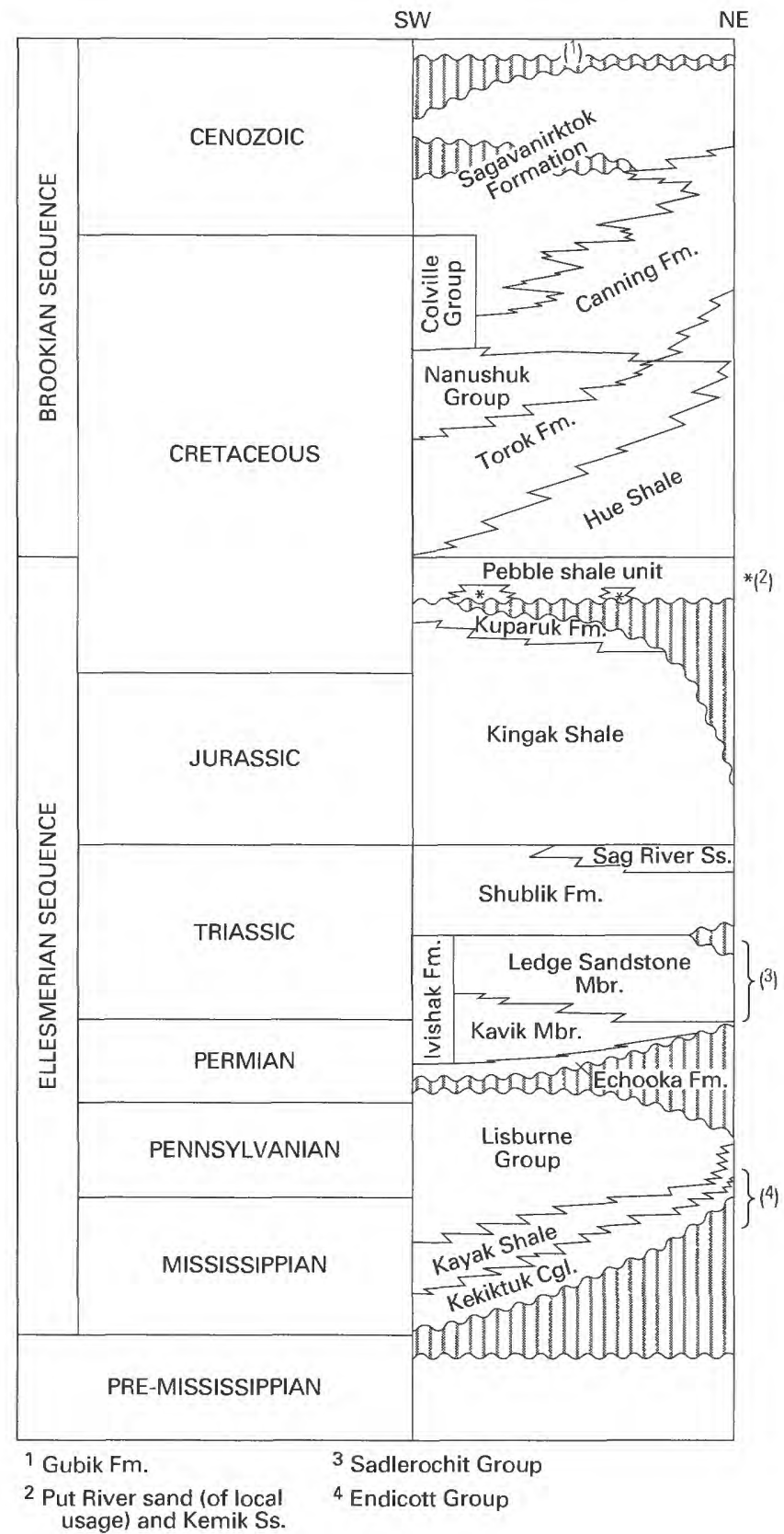

Figure 4. Generalized stratigraphic column for the Arctic Coastal Plain province (058), Alaska. Vertical line pattern, hiatus. 


\section{TOPSET PLAY (020)}

The Topset play consists of stratigraphic traps in sandstone reservoirs of Cretaceous and Tertiary age and includes those rocks represented on seismic records in the topset position of a clinoform sequence. These rocks, the Nanushuk Group and Sagavanirktok Formation, consist of marine and nonmarine deltaic sandstone, siltstone, shale, conglomerate, and coal (fig. 4). These are the youngest petroleum prospective rocks in the province. Their total thickness, about $10,000 \mathrm{ft}$, is also the maximum drilling depth in the play area. The play is limited to the area of relatively flat lying strata within the coastal plain.

Reservoir rocks consist of sandstone and conglomerate and may comprise as much as half of the total thickness of the play interval, even though individual beds seldom exceed $50 \mathrm{ft}$. Fair to good reservoir continuity is expected parallel to depositional strike (northwesterly), but marked changes may occur over short distances perpendicular to strike. The expectation is that porosity increases eastward, from 10 to 20 percent in the western part of the play to $>20$ percent in the eastern part.

Potential source rocks are interbedded deltaic shales and mudstones which are immature and probably gas prone. Beneath the play interval are marine foreset and bottomset shales and the informally designated pebble shale unit; these rocks are fair to good oil source rocks and are thermally immature to marginally mature in the play area. Oil shows are reported in several wells just west of the ANWR (Arctic National Wildlife Refuge) from the lower part of the Sagavanirktok Formation. The multi-billion barrel West Sak and Ugnu heavy oil and tar accumulations (Nos. 1 and 2, fig. 5) just west of the Prudhoe Bay field are within this play as are the smaller oil accumulations, Fish Creek and Simpson (Nos. 3 and 4, fig. 5), located in the northeastern part of the NPRA (National Petroleum Reserve in Alaska).

Postulated traps are mostly stratigraphic and are related to facies changes, cutand-fill structures, or traps formed against small-displacement normal faults. Faults and interbedded shales are expected to provide only fair to poor seals. Because of the poor sealing characteristics, hydrocarbon accumulations are expected to consist of oil rather than gas. Although thousands of wells (exploratory and development) have penetrated the rocks of the play, relatively few have been drilled for prospects. Future potential is excellent for oil and fair to good for gas. 
REGION 1, ALASKA: REGION 2, PACIFIC COAST

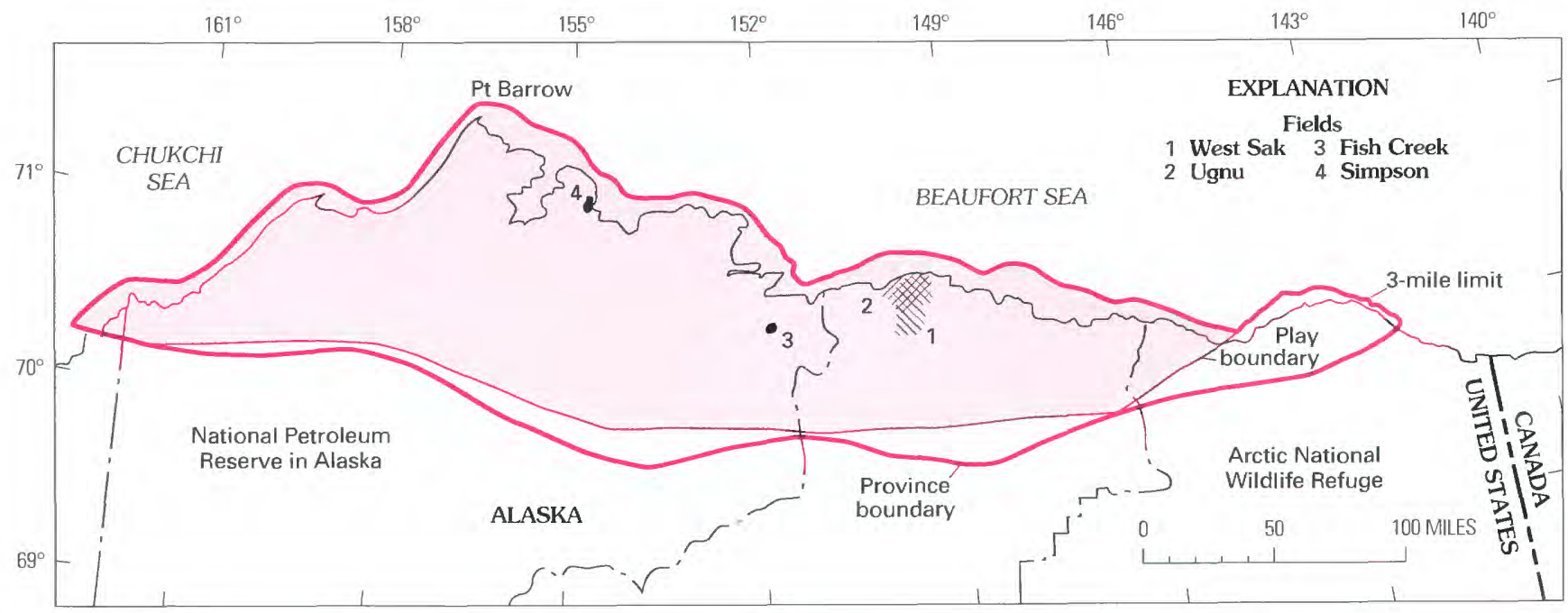

Figure 5. Map of Topset play (058-020). Fields numbered and labeled.

OIL AND GAS PLAY DATA

PLAY TOPSET PROVINCE ARCTIC COAST AL PLAIN CODE 01-058-020

Play attributes

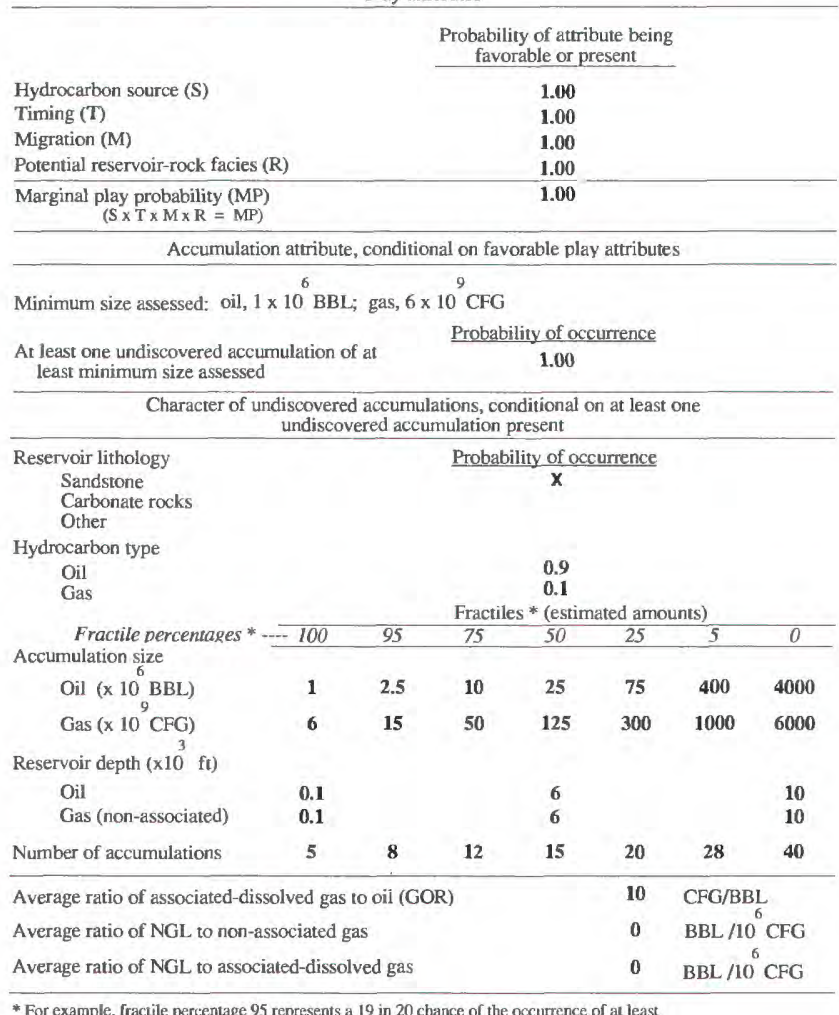

For example, fractile percentage 95 represents a 19 in 20 charce of the occurrence of at least 


\section{WESTERN TURBIDITE PLAY (030)}

This play consists of stratigraphically trapped deep-marine sandstone reservoirs of Cretaceous age, and includes those rocks represented by the foreset and bottomset seismic reflectors in the clinoform sequence beneath the western part of the coastal plain (fig. 6). The play is limited to the Torok Formation, the eastern limit of which lies at about long $150^{\circ} 30^{\prime} \mathrm{W}$., where the Torok thins by downlap to less than $300 \mathrm{ft}$ and grades laterally into the Hue Shale. Rock types are predominantly marine shale and siltstone with minor amounts of sandstone. Maximum thickness in the play interval is about $6,000 \mathrm{ft}$, and drilling depths range from near the surface in the Barrow area to a maximum depth of about $10,000 \mathrm{ft}$.

Reservoir rocks may occur anywhere within the Torok, but they are most frequently encountered in the lower half as toe-of-slope or basin-plain turbidites. Individual sandstone bodies are expected to be thin, and laterally discontinuous; aggregate reservoir thickness may be on the order of $100 \mathrm{ft}$ or more. Porosity in Torok sandstones is expected to be in the 5-15 percent range.

Source rocks include the marine shale of the Torok, which is expected to be relatively gas prone, and the underlying Hue Shale, pebble shale unit, Kingak Shale, and Shublik Formation, all of which are relatively more oil prone shales. All of these shales are marginally mature to mature. Oil and gas indications have been found in numerous wells; however, no accumulations are known in the play.

Postulated traps are stratigraphic and are related to facies changes or traps formed against small-displacement normal faults. Faults and the surrounding thick marine shales are expected to provide fair to good seals. Several dozen exploratory wells have been drilled; most wells were drilled for targets beneath the play interval-a reflection of the difficulty in mapping prospects within the play. Future oil potential is fair and the potential for gas is very good. 
REGION 1, ALASKA; REGION 2, PACIFIC COAST

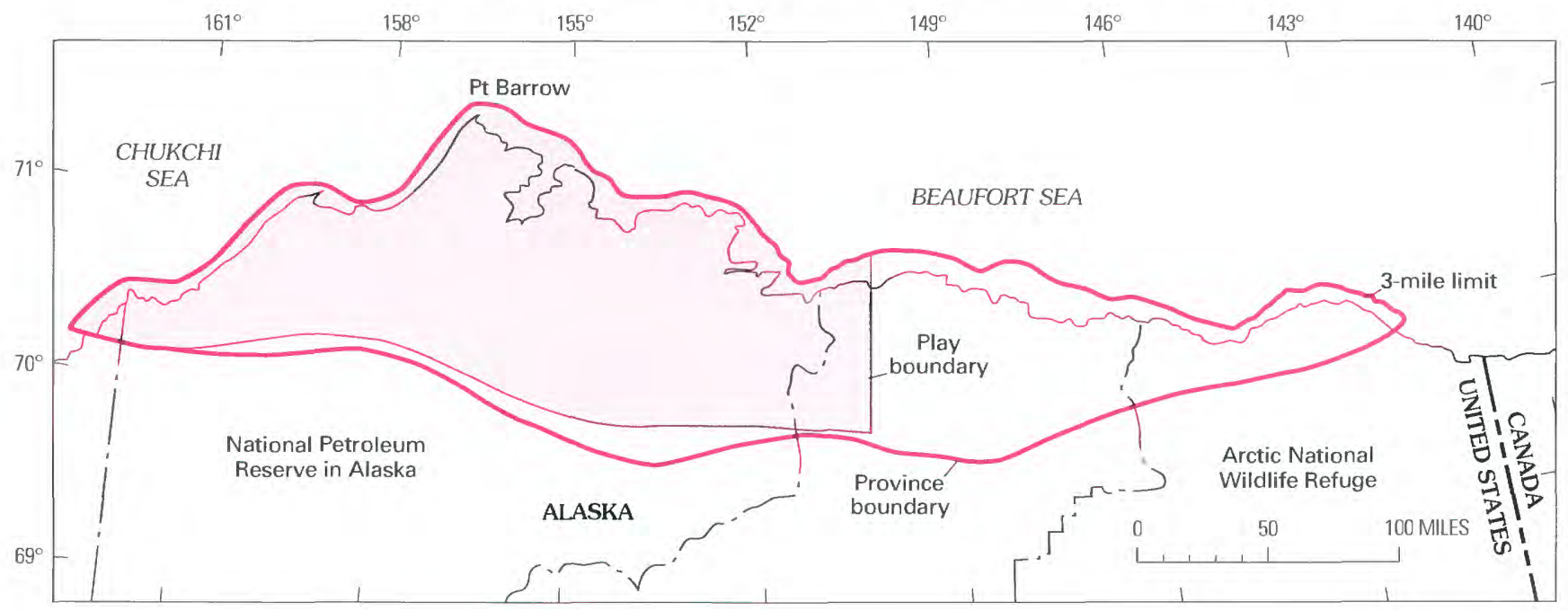

Figure 6. Map of Western Turbidite play (058-030).

OIL AND GAS PLAY DATA

PLAY WESTERN TURBIDITE

Play attributes

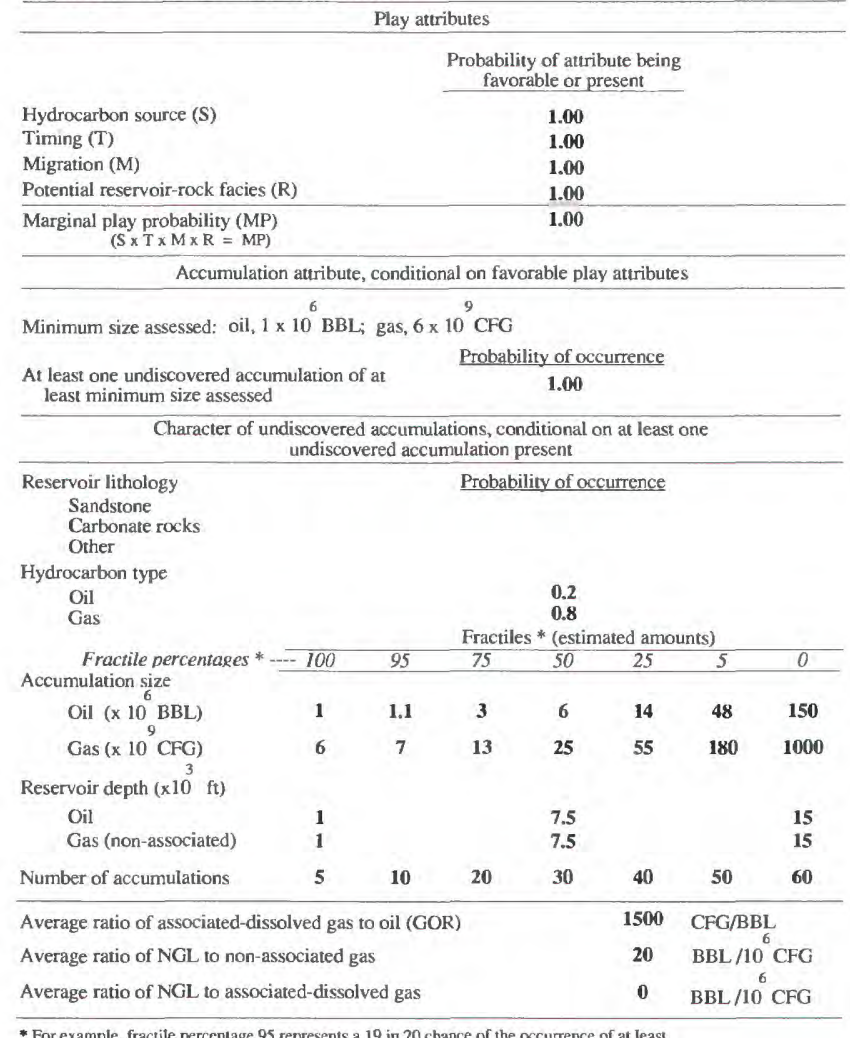

example, fractite percentage 95 represents a 19 in 20 chance of the occurrence of at lea 


\section{EASTERN TURBIDITE PLAY (040)}

The Eastern Turbidite play consists of stratigraphically trapped deep-marine sandstone reservoirs of Late Cretaceous and Tertiary age, primarily the Canning Formation, and includes those rocks represented by the foreset and bottomset seismic reflectors in the clinoform sequence beneath the eastern part of the coastal plain (fig. 7). West of long $150^{\circ} 30^{\prime} \mathrm{W}$., the play includes a marine shale tongue, a part of the Colville Group which overlies rocks of the Western Turbidite play, and part of the Nanushuk Group. Rock types are predominantly marine shale and siltstone with minor amounts of sandstone. The maximum play interval thickness is about $6,000 \mathrm{ft}$, and drilling depths range from near the surface in the westernmost part of the play to a maximum depth of about $15,000 \mathrm{ft}$.

Reservoir rocks may occur anywhere within the play interval, but are most frequently encountered in the lower half as toe-of-slope or basin-plain turbidites. Individual sandstone bodies are expected to be thin and laterally discontinuous; aggregate reservoir thickness may be on the order of $100 \mathrm{ft}$ or more. Porosity in Canning sandstones is expected to be in the $10-30$ percent range. Abnormally high fluid pressures are present in the easternmost part of the play, and as a result, porosities should be better than normally expected for rocks at these depths.

Source rocks include the marine shale of the Canning, which is expected to be relatively gas prone, and the underlying Hue Shale, pebble shale unit, Kingak Shale, and Shublik Formation, which are relatively more oil prone shales. All these shale units are marginally mature to mature. Oil and gas have been recovered from turbidite reservoirs in several wells in the Point Thomson-Flaxman Island area (No. 1, fig. 7) adjacent to the ANWR. The upper of two oil-bearing reservoirs in the recently discovered Point McIntyre field (No. 2, fig. 7), located in State waters in Prudhoe Bay, may be in this play.

Postulated traps are related to facies changes or formed against small-displacement normal faults. Faults and the surrounding thick marine shales are expected to provide fair to good seals. It is estimated that more than 100 exploratory wells have been drilled; however, most wells were drilled for targets beneath the play interval-a reflection of the difficulty in mapping prospects within the play. The future potential is estimated to be excellent for both oil and gas. 
REGION 1, ALASKA; REGION 2, PACIFIC COAST

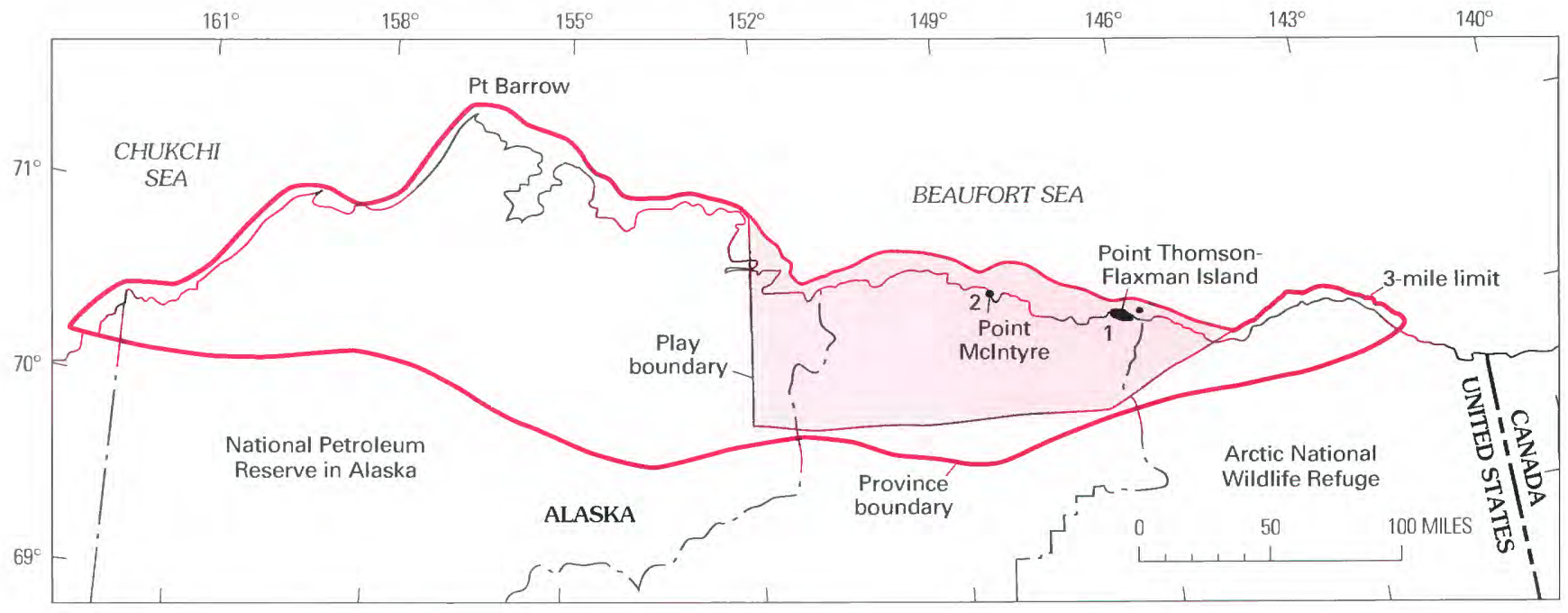

Figure 7. Map of Eastern Turbidite play (058-040). Fields numbered and labeled.

OIL AND GAS PLAY DATA

PLAY EASTERN TURBIDITE

PROVINCE ARCTIC COAST AL PLAIN

Play attributes

CODE 01-058-040

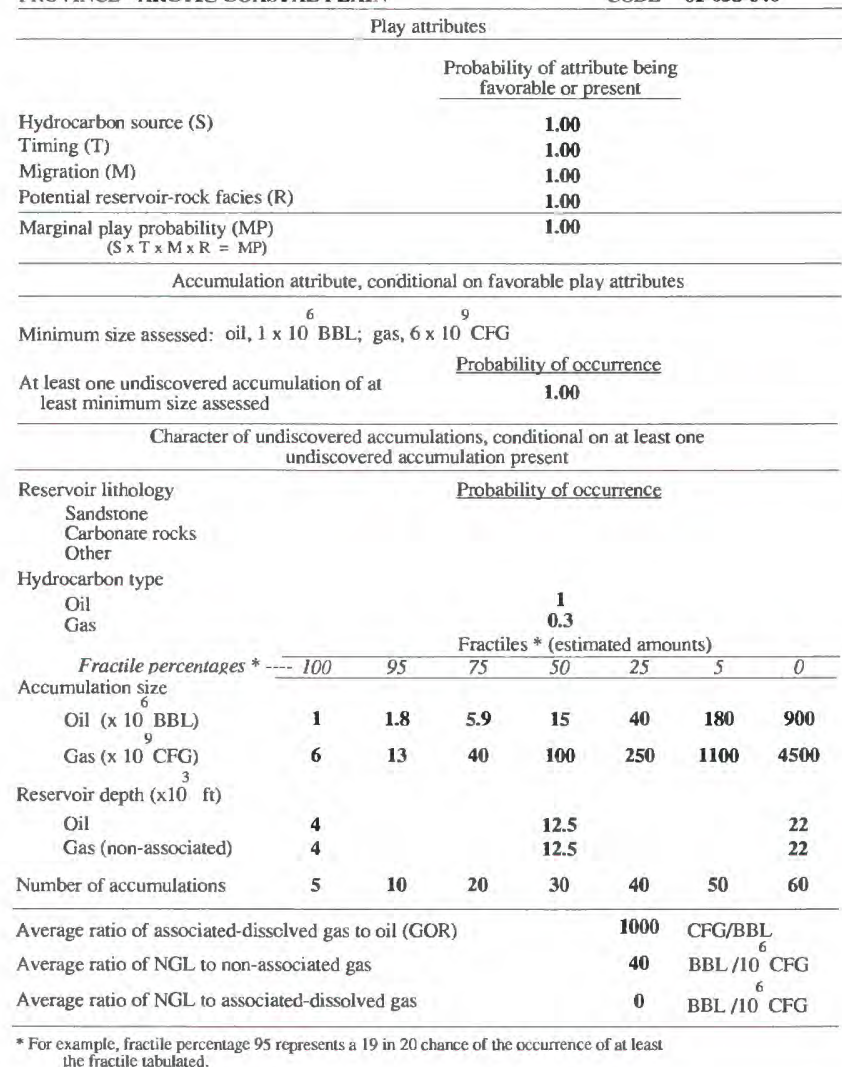




\section{BARROW ARCH PLAY (050)}

The Barrow Arch play consists of Mississippian to Early Cretaceous rocks in broad, anticlinal structures with an important component of faulting and erosional truncation in a relatively narrow strip along the northern coast of Alaska (fig. 8). The northern limit of the play is approximately the outer limit of State offshore waters. The southern limit is the downdip limit (on the south flank of the Barrow arch) of the characteristic structural-stratigraphic trapping mechanism.

Potential reservoir rocks include both sandstone and carbonate rocks (fig. 4). Sandstone reservoirs (Kekiktuk Conglomerate, Sadlerochit Group, Sag River Sandstone, unnamed Jurassic sandstones, Kuparuk Formation, and Put River sand (of local usage) and its equivalents) predominate over carbonate reservoirs (Lisburne Group). The most important reservoir is expected to be nonmarine to shallow-marine sandstone in the Sadlerochit Group. Porosity in sandstone reservoirs is expected to average more than 20 percent; limestone porosity is expected to be less than 5 percent, with that in the dolomite variable, but potentially 20 percent or more. All potential reservoirs have oil shows or are oil productive. Drilling depths range from $1,500 \mathrm{ft}$ to $15,000 \mathrm{ft}$.

Potential source rocks include marine shale of Triassic to Early Cretaceous age including the Kavik Member of the Ivishak Formation, Shublik Formation, Kingak Shale, pebble shale unit, and Hue Shale. Lacustrine shale, mudstone, and coal of Mississippian age may also be source rocks. All potential source rocks are at least marginally mature within the play area, but are mature to overmature to the south; and where present to the north, they are also overmature.

Traps are generally combinations of structure and stratigraphy. Closure is generally achieved by faulting and partial truncation of the reservoir in broad, gentle anticlines. Truncation is usually the result of a regionally prevalent Lower Cretaceous unconformity, and sealing is accomplished by the overlying pebble shale unit and younger marine shales. All currently productive North Slope fields are located in this play and are identified by number in figure 8; they are Endicott (1), Kuparuk River (2), Lisburne (3), Milne Point (4), Prudhoe Bay (5) oil fields, and South Barrow (6), and East Barrow (7) gas fields. Numerous subeconomic oil and gas accumulations include Gwydyr Bay (8), North Prudhoe Bay (9), Seal Island (10), Sandpiper (11), Tern Island (12), Point Thomson (13), Colville Delta (14), Niakuk (15), and Point McIntyre (16). This is the most intensely explored play on the North Slope with about 200 exploratory wells, some of which date from the beginning of North Slope drilling in 1946. Future potential for both oil and gas is considered to be excellent. 
REGION 1, ALASKA; REGION 2, PACIFIC COAST

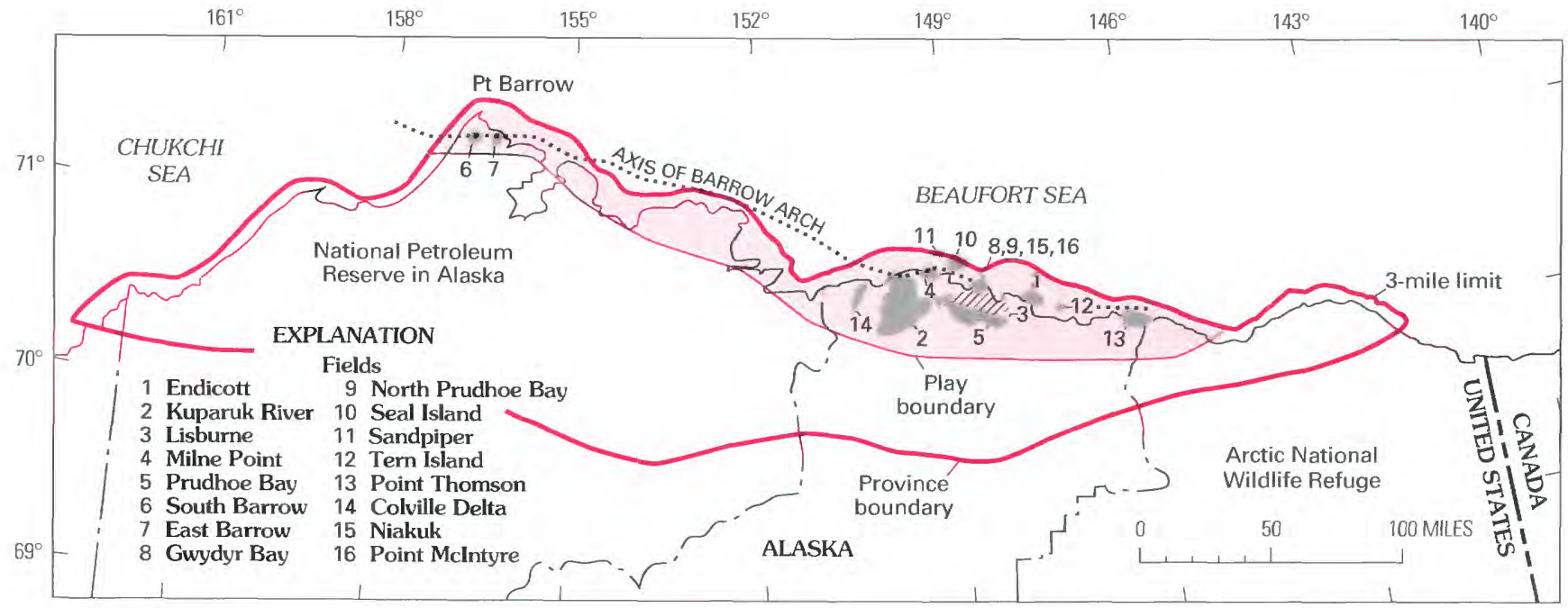

Figure 8. Map of Barrow Arch play (058-050). Fields numbered and labeled.

OIL AND GAS PLAY DATA

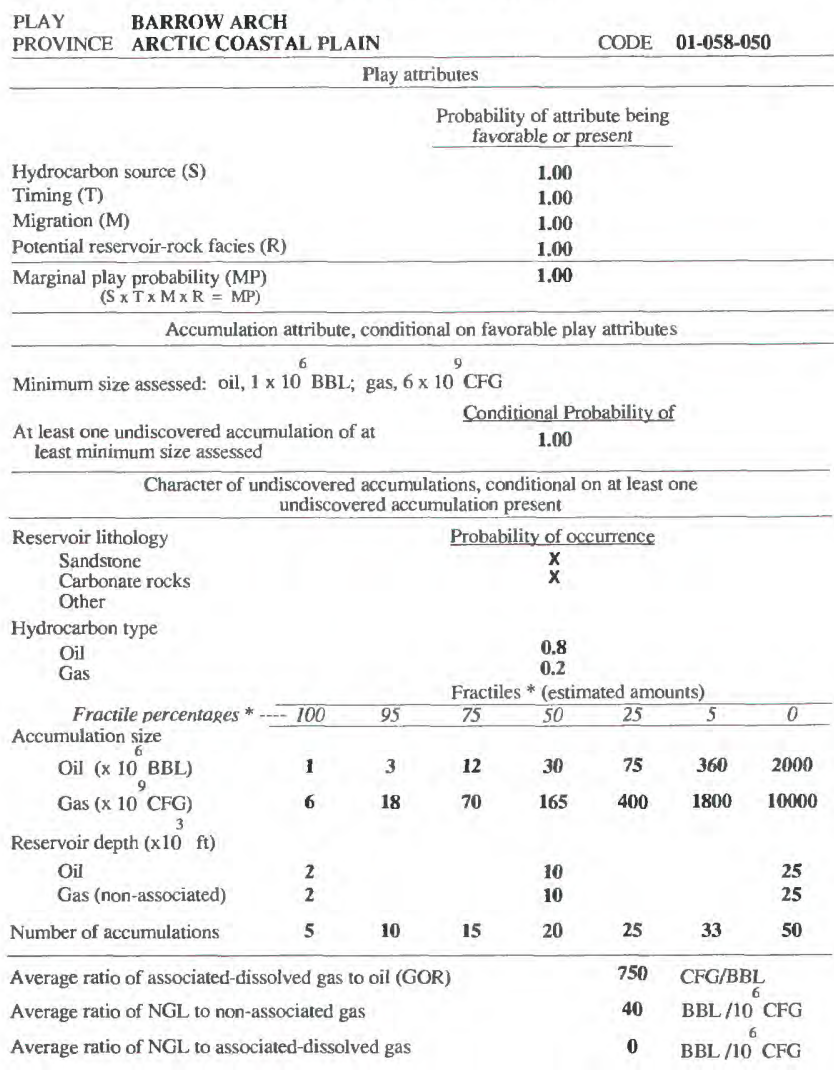
* For example, fracilite percentage 95 represents a 19 in 20 chance of the occurrence of at least
the fractile tabulated. 


\section{ELLESMERIAN CLASTICS PLAY (060)}

The Ellesmerian Clastics play consists of stratigraphic, structural, and combination structural-stratigraphic traps in sandstone reservoirs in the gently south dipping Permian to Early Cretaceous part of the Ellesmerian sequence (strata above the Lisburne Group). The play interval consists mostly of siltstone and shale with as much as 10 percent sandstone at the northern boundary, which coincides with the southern boundary of the Barrow Arch play; the play interval may be as thin as $400 \mathrm{ft}$ (fig. 9). The southern boundary lies within the northern part of the Northern Foothills province (059), where the play interval may be as thick as $6,000 \mathrm{ft}$ and occurs at depths greater than $15,000 \mathrm{ft}$.

Reservoir rocks consist of sandstone deposited primarily in shallow-marine environments. Also present are minor amounts of fluvial sandstone in the northernmost areas of the play and turbidite sandstone of northern derivation in the southernmost areas. Potential reservoirs include the Echooka Formation, Ivishak Formation, Sag River Sandstone, several unnamed sandstone units in the Kingak Shale, Kuparuk Formation, and stratigraphic equivalents of the Kemik Sandstone. Porosities may reach 25 percent in the northern parts of the play area, but are anticipated to decrease to less than 10 percent in the southern parts. Drilling depths range from 2,000 ft in the north to 20,000 $\mathrm{ft}$ at the southern play boundary. Most reservoirs, particularly those with the best porosity, are expected to occur beneath the Arctic Coastal Plain province (058), where drilling depths are generally less than $12,000 \mathrm{ft}$.

The play interval contains many of the richest source rocks on the North Slope, including the Kavik Member, Shublik Formation, Kingak Shale, pebble shale unit, and Hue Shale. These shale units are mature throughout most of the play, but range from marginally mature in the northernmost part to overmature in the southern part, where vitrinite reflectance values exceed 2 percent. Oil and gas shows are reported in several wells, and a gas accumulation of undetermined size is present immediately south of Barrow (Walakpa field, fig. 9).

Because of the homoclinal south dip of strata comprising this play and the rarity of structural reversals, oil and gas accumulations are expected to be trapped in stratigraphic or combination structural-stratigraphic traps. Shale units within the play interval are expected to provide adequate seals. A few dozen exploratory wells have been drilled, only a few of which were drilled for prospects in the play interval. Estimates of oil and gas resources in this play have been apportioned as follows: 80 percent to the Arctic Coastal Plain province (058) and 20 percent to the Northern Foothills province (059). Future oil potential is fair, and future gas potential is considered to be excellent. 
REGION 1, ALASKA; REGION 2, PACIFIC COAST

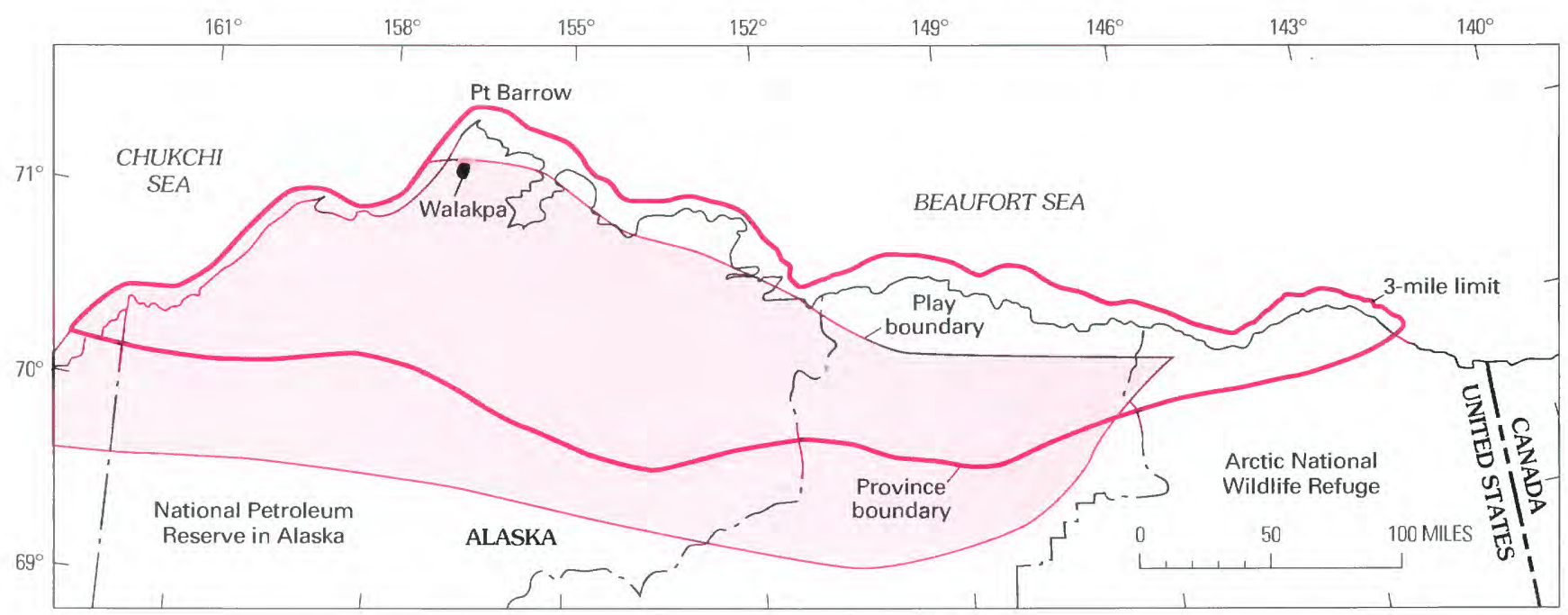

Figure 9. Map of Ellesmerian Clastics play (058-060), showing Walakpa field.

OIL AND GAS PLAY DATA

PLAY ELLESMERIAN CLASTICS

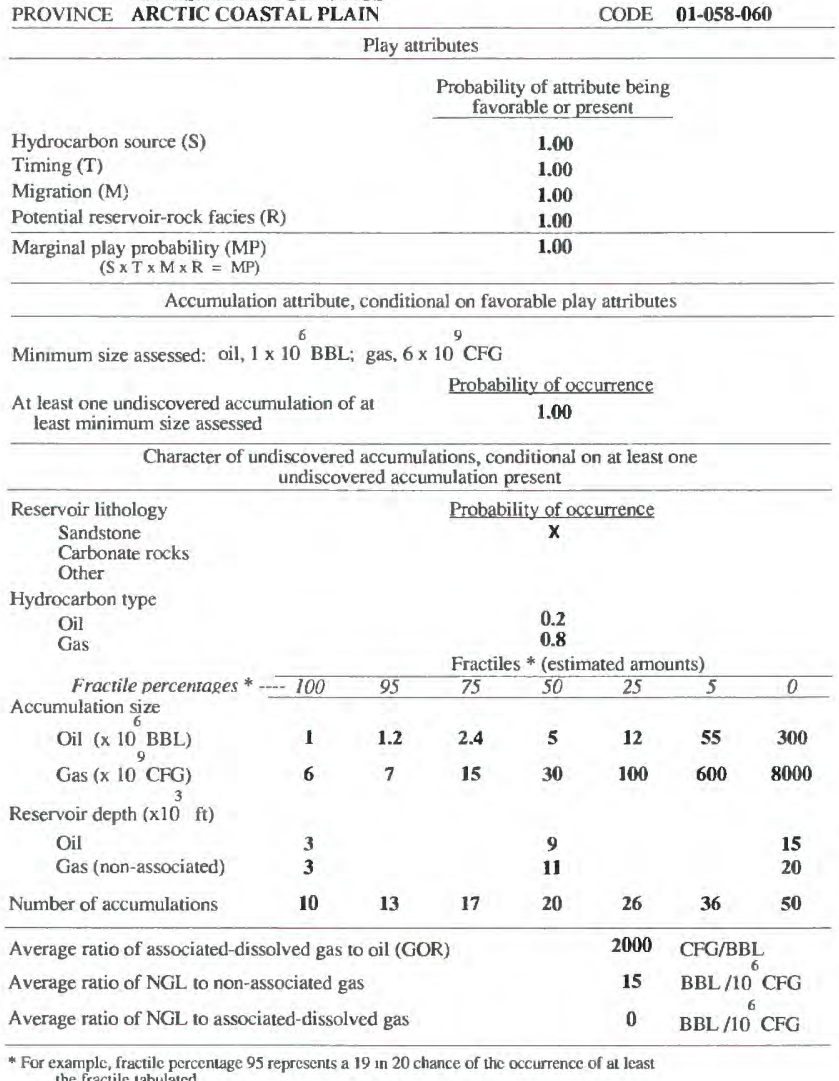

For examplc, fractile percentage 95 represents a 19 in 20 chance of the occurrence of at leas 


\section{LISBURNE PLAY (070)}

The Lisburne play consists of structurally and stratigraphically trapped hydrocarbons in carbonate or clastic reservoirs in the gently south dipping Lisburne Group. The northern boundary within the north-central part of the NPRA is the Lisburne onlap limit; east of long $154^{\circ} \mathrm{W}$., it is the southern boundary of the Barrow Arch play (fig. 10). The southern boundary is approximately the south boundary of the Arctic Coastal Plain province, where the Lisburne is buried to depths greater than $15,000 \mathrm{ft}$, and vitrinite reflectance values exceed 2 percent. The Lisburne Group is composed of shallow-marine limestone and dolomite with minor amounts of interbedded shale and sandstone. Lisburne thickness varies widely but may be as much as $4,000 \mathrm{ft}$.

Potential reservoir rocks include dolomite, limestone, and sandstone. Dolomite is the most important reservoir; in some places dolomite porosity reaches 25 percent. Dolomite is expected to occur most abundantly in the Late Mississippian part of the Lisburne, as in the Prudhoe Bay area. Limestone porosity in the Lisburne is expected to average less than 5 percent; thus limestone constitutes a poor potential reservoir. Sandstone, which may be common along the northern onlap edge in the NPRA, may be partially to completely calcite cemented and, thus, a marginal reservoir. Depth to the top of the Lisburne ranges from $9,000 \mathrm{ft}$ to $20,000 \mathrm{ft}$.

Potential source rocks include marine shale in the overlying Sadlerochit Group, marine shale and limestone within the Lisburne, and marine to lacustrine shale and coal in the underlying Endicott Group. Where truncated by the regional Lower Cretaceous unconformity, such as along the west edge of the ANWR, the pebble shale unit and the Hue Shale overlie the unconformity and may be important source rocks for the Lisburne. Limited geochemical data suggest that all except the pebble shale unit and Hue Shale are fair to poor, gas-prone source rocks that are mature in the northern part of the play and overmature in the southern part. Oil residue is often encountered in porous dolomite in the Lisburne, and hydrogen sulfide gas was encountered in interbedded limestone and shale near the Lisburne-Endicott boundary at a depth of about $17,500 \mathrm{ft}$ in the Inigok-1 well, near the southern play boundary in the eastern NPRA (fig. 10).

Stratigraphic traps related to the Lisburne onlap edge and facies changes are expected in the northern part of the play area. Structural traps are relatively rare, although in the NPRA folding and faulting during Mississippian, Pennsylvanian, and Permian(?) time produced some structures, such as that drilled by the Inigok exploratory well. Seismic reflection records in the northwestern part of the NPRA suggest that carbonate buildups may be present. Interbedded shale and impermeable limestone are expected to provide adequate seals. Only a few exploratory wells have been drilled for prospects in this play, and no hydrocarbon accumulations are known. Future oil potential is poor, but the gas potential is thought to be significant. 
REGION 1, ALASKA; REGION 2, PACIFIC COAST

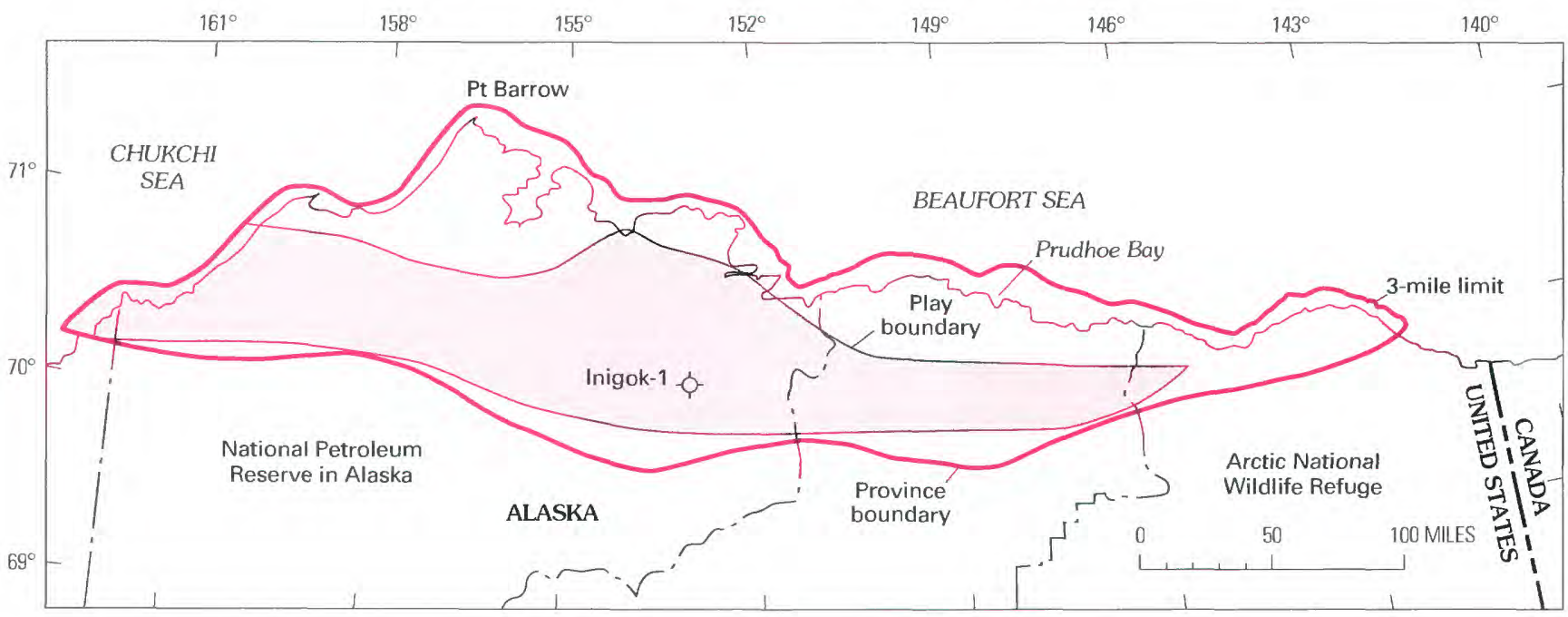

Figure 10. Map of Lisburne play (058-070). Inigok-1 exploratory well shown.

OIL AND GAS PLAY DATA

$\begin{array}{ll}\text { PLAY } & \text { LISBURNE } \\ \text { PROVINCE } & \text { ARCTIC COASTAL PLAIN }\end{array}$

CODE 01-058-070

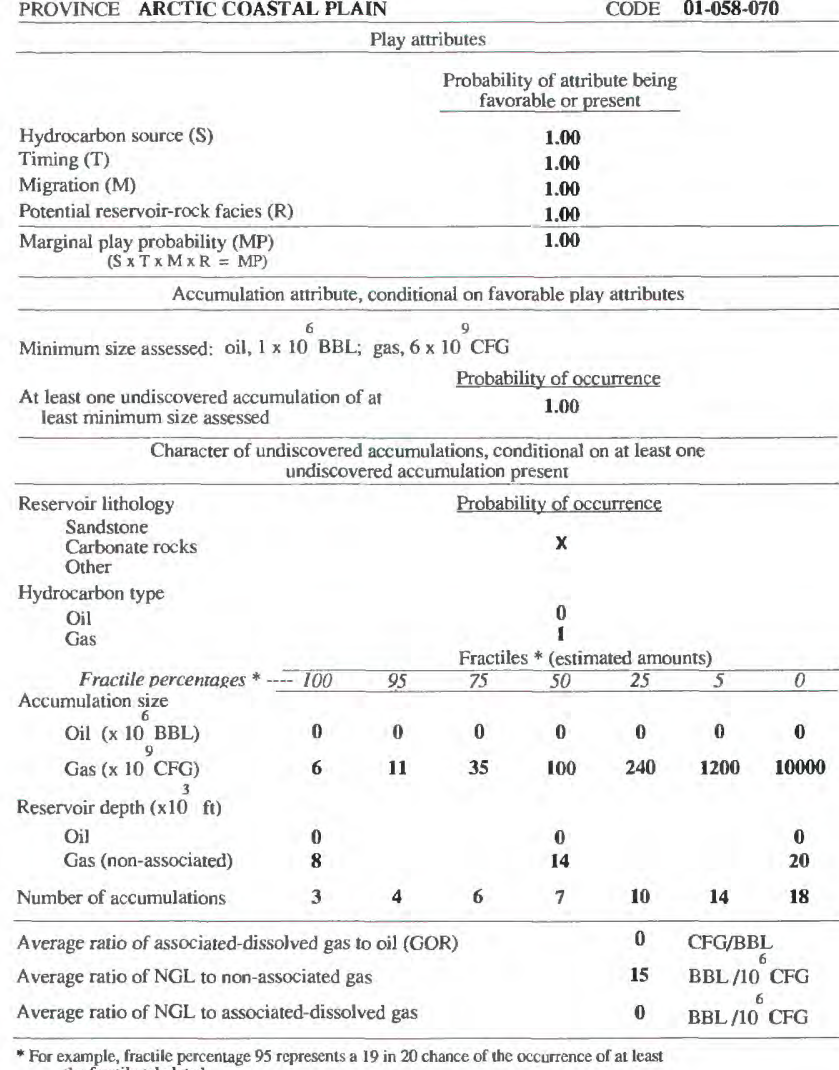

For example, fraciile percentage 95 represents a 19 in 20 chance of the occurrence of at leas 


\section{LISBURNE UNCONFORMITY PLAY (080)}

The Lisburne Unconformity play consists of stratigraphic traps developed as a result of differential erosion on the regional Permian unconformity at the top of the Lisburne Group (fig. 11). Postulated traps are envisioned to consist of erosional scarps and remnants of porous Lisburne carbonate rocks sealed by the overlying Sadlerochit Group. These traps are analogous to those which trap most Mississippian oil and gas accumulations beneath the plains of Alberta, Canada. The play is considered speculative because the amount of differential erosion on the Permian unconformity is largely unknown. Evidence for relief on this unconformity is known from outcrops in the eastern Shublik Mountains of the ANWR, where conglomerate-filled channels cut into the uppermost part of the Lisburne Group.

The play encompasses the entire area of the Lisburne Group beneath the Permian unconformity, including that area overlying the Barrow arch (fig. 8). The Barrow arch area is included in this play because the size distribution of oil and gas accumulations in the play is likely to be significantly different from that in the Barrow Arch play. The southern limit of the play coincides with the southern limit of the Lisburne play.

Reservoir rocks and source rocks are expected to be the same as for the Lisburne play. Depth to the Lisburne unconformity in the play area ranges from about $8,000 \mathrm{ft}$ to $20,000 \mathrm{ft}$. As many as 50 exploratory wells may have penetrated this play, but most were drilled for targets beneath the play interval. Future potential for undiscovered oil is low, but gas potential is very good. 
REGION 1, ALASKA; REGION 2, PACIFIC COAST

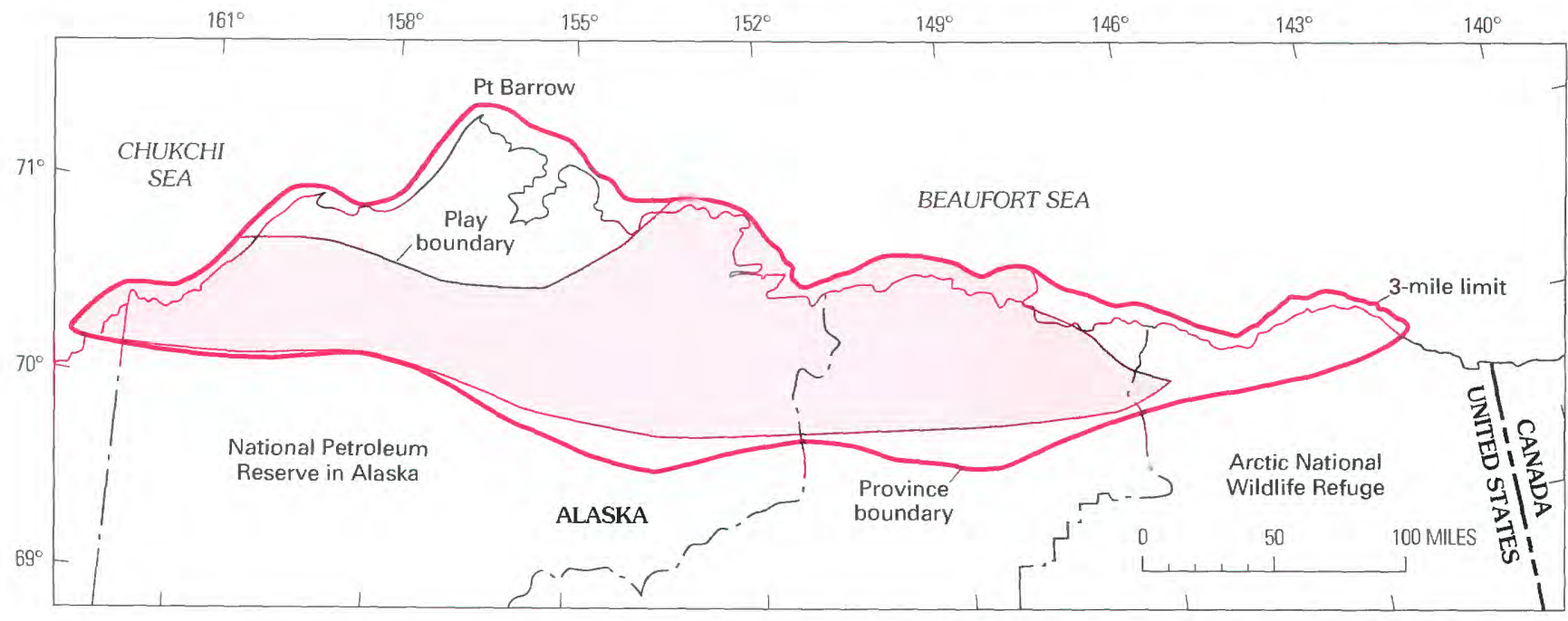

Figure 11. Map of Lisburne Unconformity play (058-080).

OIL AND GAS PLAY DATA

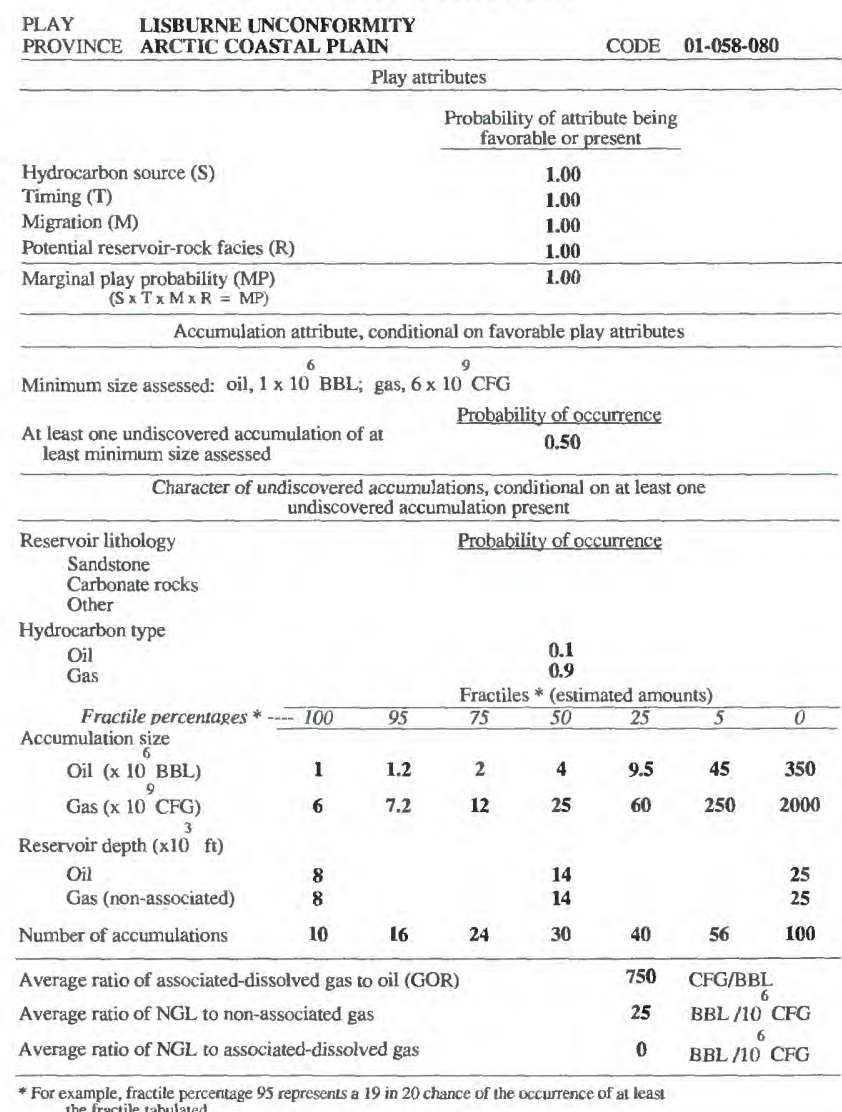




\section{ENDICOTT PLAY (090)}

The Endicott play consists of structural, stratigraphic, and combination traps in sandstone reservoirs in the Mississippian Kekiktuk Conglomerate and sandstone or dolomite reservoirs in the overlying Kayak Shale, both formations belonging to the Endicott Group. The northern boundary of the play in the north-central part of the NPRA is the onlap edge of the Endicott Group; east of long $155^{\circ} \mathrm{W}$., it is the southern boundary of the Barrow Arch play (fig. 12). The southern boundary of the play approximates the southern boundary of the province, where these rocks are buried to depths of more than $20,000 \mathrm{ft}$ and have vitrinite reflectance values that exceed 2 percent. Thickness of the Endicott Group generally ranges from 100 to $1,000 \mathrm{ft}$ but locally may be as much as $10,000 \mathrm{ft}$.

Reservoir rocks consist primarily of fluvial to shallow-marine(?) quartzose sandstone and conglomerate within the Kekiktuk Conglomerate. Minor amounts of shallowmarine dolomite and sandstone are present in the overlying Kayak Shale. Porosity is generally expected to be less than 10 percent because of burial depths ranging from 7,000 to greater than $20,000 \mathrm{ft}$. Increased porosity in the Kekiktuk may be present beneath the Lower Cretaceous unconformity, along the west edge of the ANWR.

Source rocks include coal and lacustrine shale in the Kekiktuk, marine shale in the Kayak, and, where truncation is present, the pebble shale unit and the Hue Shale. Throughout most of the play area these rocks are overmature. Accordingly, few oil and gas shows are known from this play. However, in the Inigok-1 well, located near the southern play boundary in the eastern part of the NPRA (fig. 12), hydrogen sulfide gas occurred in the uppermost part of the Kayak Shale, at a depth of about $17,500 \mathrm{ft}$.

Traps are expected to be mostly combination traps related to faulting. Locally, folds and faults were developed during the formation of Endicott basins in Mississippian, Pennsylvanian, and Permian(?) time. The Kayak Shale is expected to provide adequate seals for any reservoirs which may occur in the play. Less than a dozen exploratory wells have been drilled, and the potential for undiscovered gas resources is thought to be moderate. 
REGION 1, ALASKA; REGION 2, PACIFIC COAST

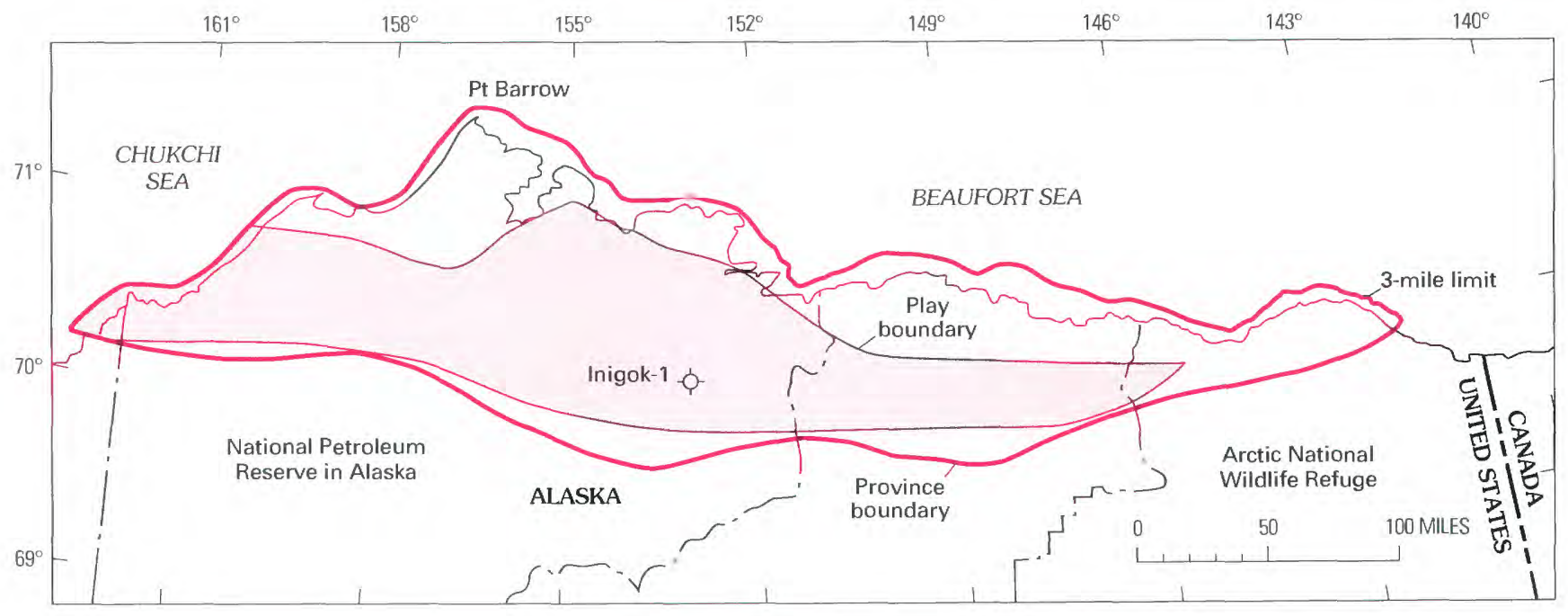

Figure 12. Map of Endicott play (058-090), showing Inigok-1 well.

OIL AND GAS PLAY DATA

PLAY

ENDICOTT

PROVINCE ARCTIC COASTAL PLAIN

CODE 01-058-090

Play attributes

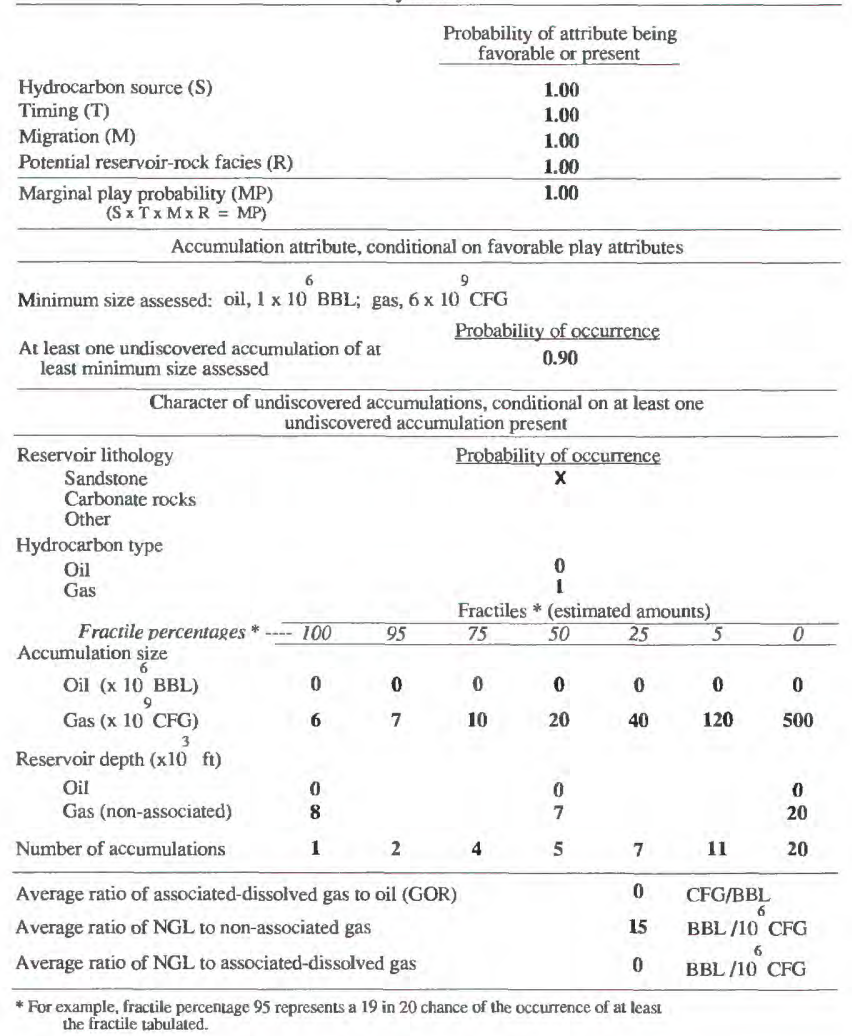




\title{
NORTHERN FOOTHILLS PROVINCE (059)
}

\author{
By Kenneth J. Bird

\section{INTRODUCTION}

The Northern Foothills province is one of three provinces that make up the Alaskan North Slope (fig. 3). The province area extends about $600 \mathrm{mi}$ from the Chukchi Sea on the west to the Canadian border on the east. Its maximum width is about 100 $\mathrm{mi}$. Along the west edge of the province, the State 3-mile limit forms the seaward boundary. The total area of the province is about $29,000 \mathrm{mi}^{2}$. The North Slope is a Cretaceous and Tertiary foreland basin developed on a Mississippian to Early Cretaceous passive margin; the stratigraphy is detailed in figure 13. The province occupies the distal part of the Brooks Range fold-and-thrust belt. Deformation involves mostly foreland basin strata, except in the ANWR, where deformation extends to deeper stratigraphic levels and involves pre-foreland basin rocks. The province was the site of the first North Slope oil discovery, Umiat field, made in the NPRA by the U.S. Navy in 1946. Since then about 50 exploratory wells have been drilled by industry and government resulting in the discovery of six hydrocarbon accumulations-one oil and five gas. All accumulations are noncommercial. Umiat, the only oil field, is estimated to have about $70 \mathrm{MMB}$ of recoverable oil. The largest gas field is Gubik with an estimated 295 BCF of recoverable gas. Two plays were individually assessed: Fold Belt West and Fold Belt East. 
REGION 1, ALASKA: REGION 2, PACIFIC COAST

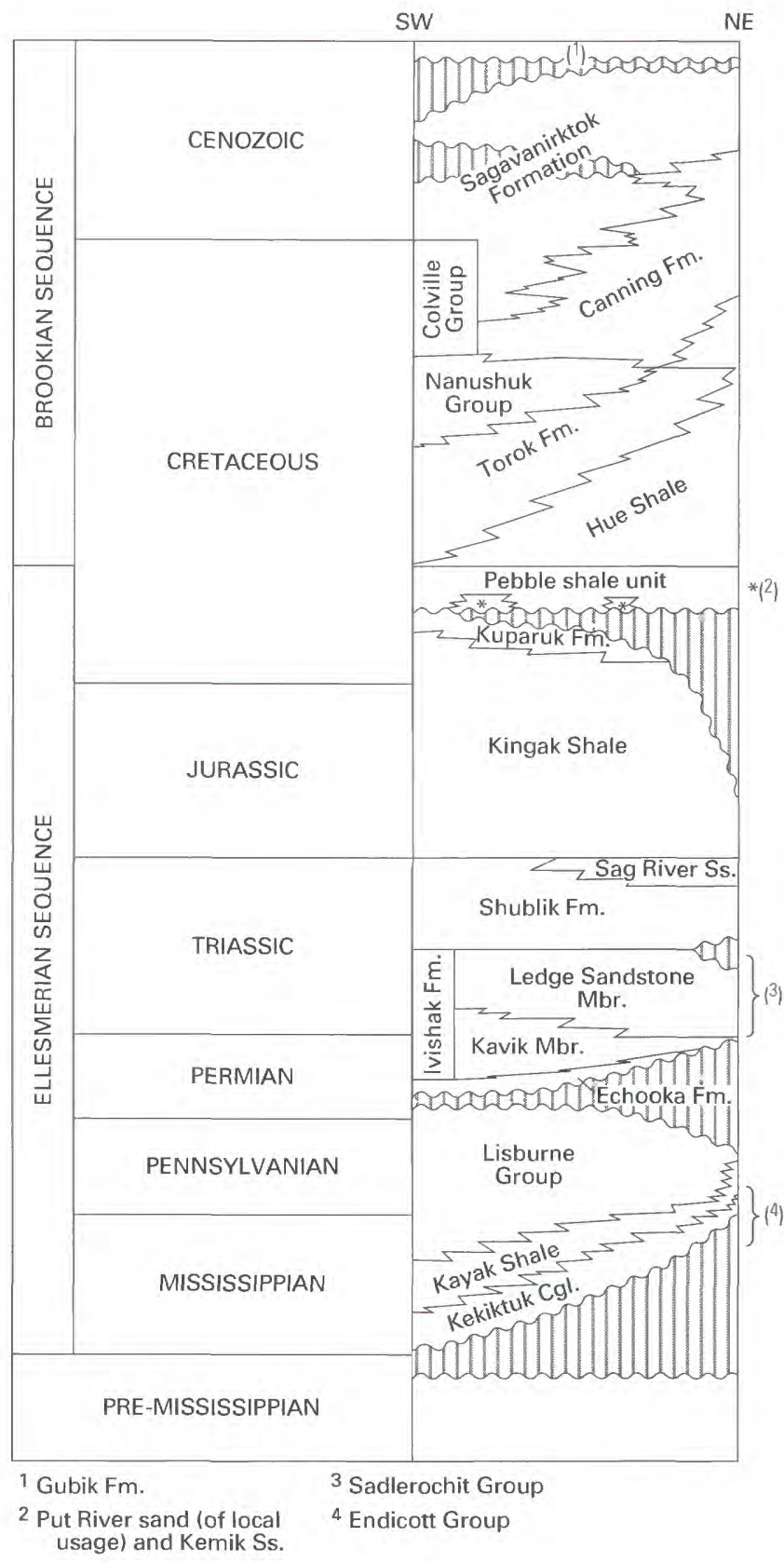

Figure 13. Generalized stratigraphic column, Northern Foothills province (059). 


\section{FOLD BELT WEST PLAY (020)}

The Fold Belt West play consists primarily of anticlinal traps in Cretaceous and Tertiary sandstone reservoirs in the northern part of the Brooks Range fold-and-thrust belt. The play is situated north of the Thrust Belt West play of the Southern Foothills province (060), and south of undisturbed deposits of the Brookian sequence of the Arctic Coastal Plain province (058); its western border is the State 3-mile limit in the Chukchi Sea; its eastern border lies a short distance east of the Trans-Alaska Pipeline, where the structural style changes (fig. 14). This play encompasses rocks of the Nanushuk Group, Torok Formation, Hue Shale, pebble shale unit, and sandstones correlative with the Kemik Sandstone; in the eastern quarter of the play, parts of the Sagavanirktok and Canning Formations are also included.

Potential reservoirs are sandstones, representing deltaic, shallow-marine, and turbidite environments. Sandstone porosity is expected to range from 5 to 20 percent and to increase eastward across the play. Drilling depths range from the near-surface to greater than $20,000 \mathrm{ft}$.

Potential source rocks include generally gas prone shale units of the Nanushuk Group and the Sagavanirktok, Torok, and Canning Formations and the underlying more oil prone shale units of the Shublik Formation, Kingak Shale, pebble shale unit, and Hue Shale. Gas-prone source rocks within the play range from immature to mature, whereas most oil prone source rocks range from mature to overmature. Both oil and gas seeps are known, and six subeconomic accumulations have been discovered: the Umiat oil field (1), and the Gubik (2), East Umiat (3), Wolf Creek (4), Square Lake (5), and Meade (6) gas fields. These are identified in figure 14.

Traps are fault-cored anticlines related to Brooks Range thrusting. Stratigraphic traps, such as updip pinchouts on the flanks of anticlines, may also be present. Shales are expected to provide fair to good seals, although their effectiveness may be reduced by faulting and related fracturing. Approximately 40 exploratory and delineation wells have tested 30 structures in the play; however, the number of untested structures may exceed 100. Estimates of oil and gas resources in the play have been apportioned 98 percent to the Northern Foothills province (059), and 2 percent to the Southern Foothills-Brooks Range province (060). Future potential for both oil and gas is excellent. 
REGION 1, ALASKA; REGION 2, PACIFIC COAST

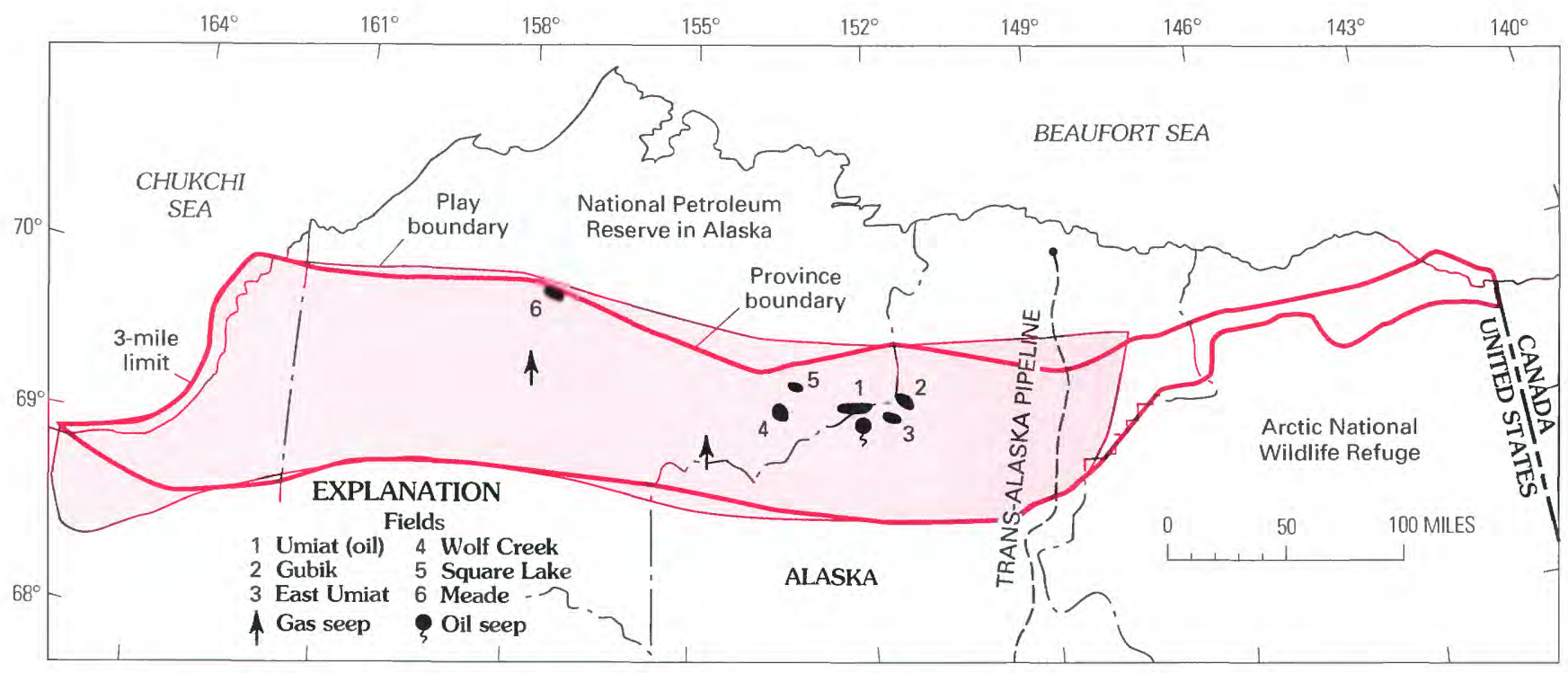

Figure 14. Map of Fold Belt West play (059-020). Fields numbered and labeled.

OIL AND GAS PLAY DATA

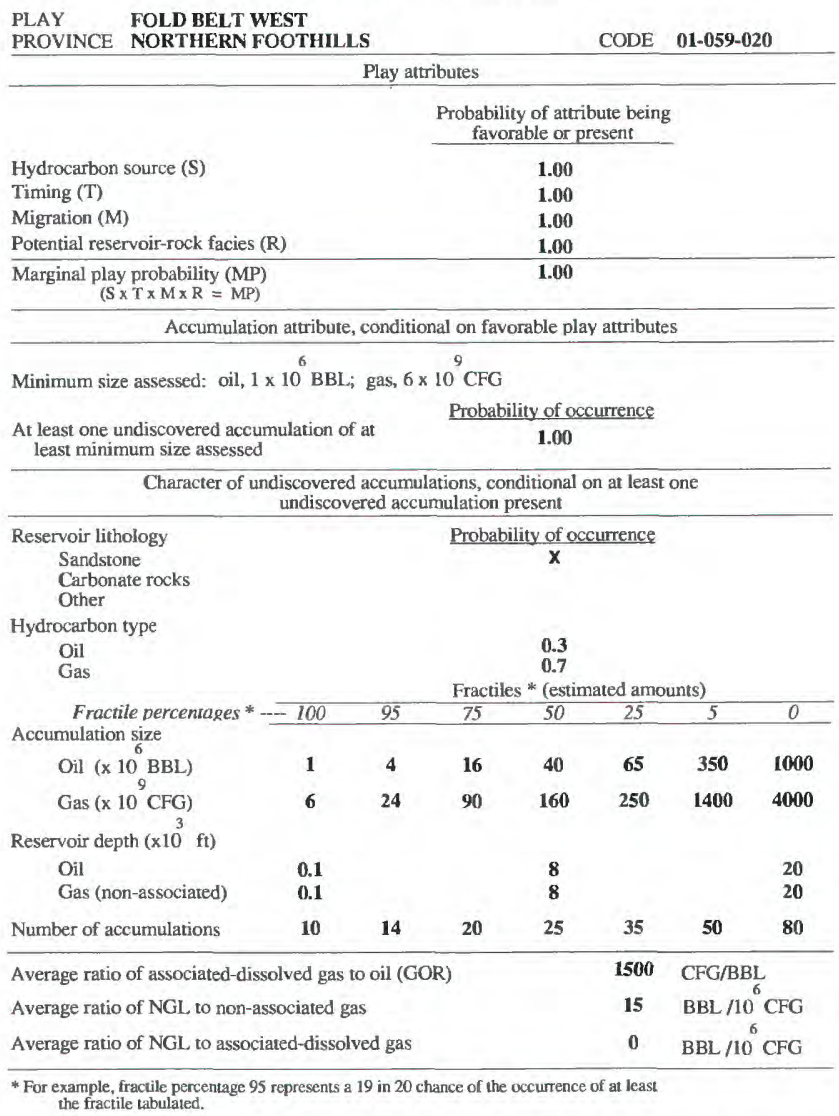




\section{FOLD BELT EAST PLAY (030)}

The Fold Belt East play consists primarily of anticlinal traps in Cretaceous and Tertiary sandstone reservoirs in the northern part of the Brooks Range fold-and-thrust belt. The play is situated north of the Thrust Belt East play of the Southern FoothillsBrooks Range province (060), and south of the undisturbed Brookian sequence deposits of province 058. The east half of the play extends offshore to the State 3-mile limit in the Beaufort Sea. Its western border lies a short distance east of the Trans-Alaska Pipeline, where the structural style changes (fig. 15). In general regional terms, the Fold Belt East play structurally overlies the Thrust Belt East play of province 060. The Fold Belt East play includes rocks of the Sagavanirktok and Canning Formations, Hue Shale, pebble shale unit, and Kemik Sandstone.

Potential reservoir rocks are sandstone units, representing deltaic, shallow-marine, and turbidite environments. Porosity is expected to increase eastward across the play (by 10 to 30 percent or more) because of lesser burial and shorter duration of burial in that direction. Drilling depths range from the near-surface to greater than $20,000 \mathrm{ft}$.

Potential source rocks include gas-prone shale in the Sagavanirktok and Canning Formations and oil-prone shale in the Hue Shale, pebble shale unit, Kingak Shale, and Shublik Formation. This play is considered more oil prospective than the Fold Belt West play because of the presence of a thicker section of the oil-prone Hue Shale. Gasprone source rocks are immature to mature, whereas oil-prone source rocks are immature to overmature. Oil seeps and oil-stained sandstones are known, but no oil or gas accumulations have been discovered.

Traps are fault-cored anticlines related to Brooks Range thrusting. Stratigraphic traps, such as updip pinchouts on the flanks of anticlines, may also be present. Shales within the play are expected to provide fair to good seals, although their effectiveness may be reduced by faulting and related fracturing. About 10 exploratory wells have penetrated rocks assigned to this play; however, most wells are believed to have been drilled for objectives assigned to the underlying Thrust Belt East play. Untested structures may number more than 100. Estimated undiscovered oil and gas resources in the play have been apportioned 73 percent to the Arctic Coastal Plain province (058), 25 percent to the Northern Foothills province (059), and 2 percent to the Southern Foothills-Brooks Range province (060). Future potential for oil and gas is considered excellent. 
REGION 1, ALASKA; REGION 2, PACIFIC COAST

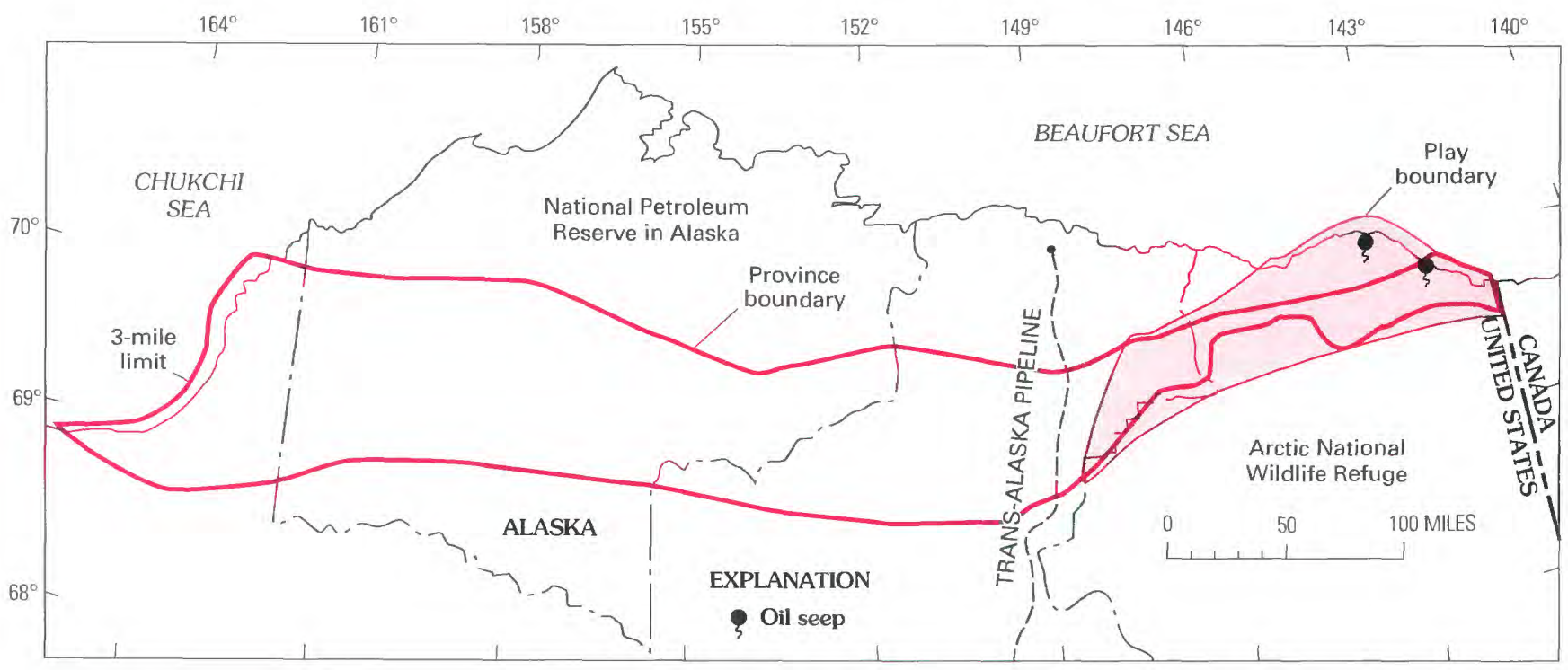

Figure 15. Map of Fold Belt East play (059-030).

OIL AND GAS PLAY DATA

PLAY FOLD BELT EAST

PROVINCE NORTHERN FOOTHILLS

Play attributes

CODE 01-059-030

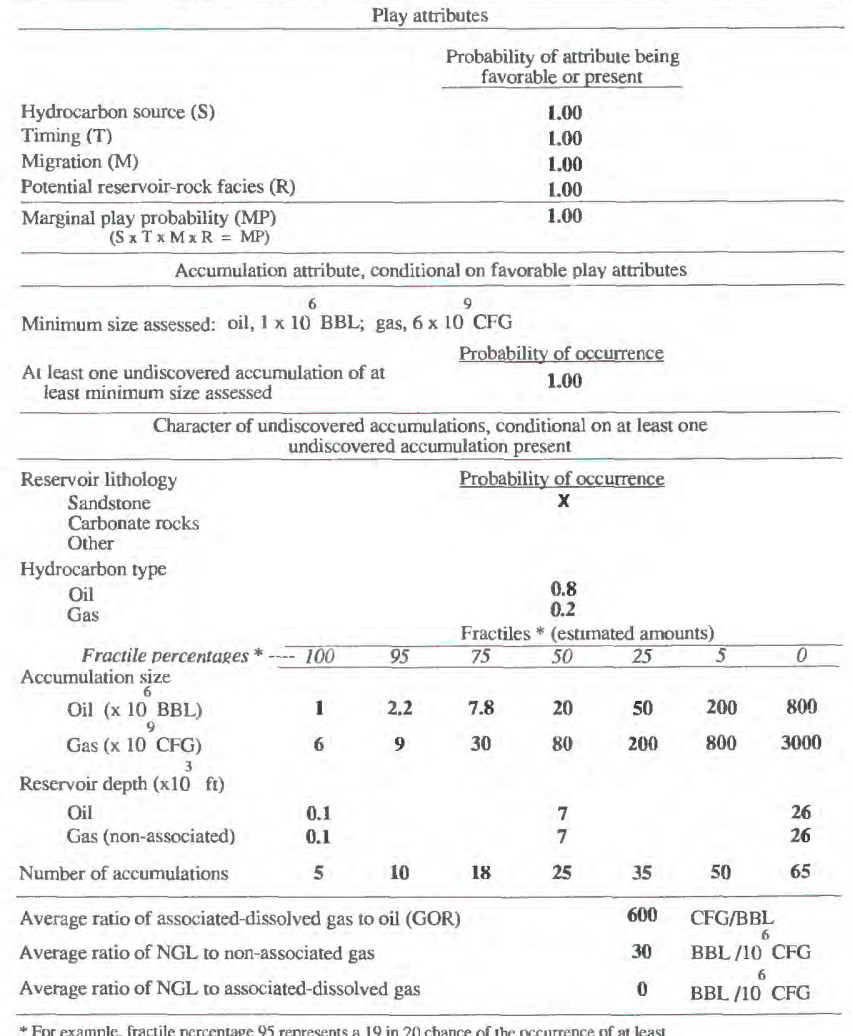

for example, fractile percentage 95 represents a 19 in 20 chance of the occurrence of at leass
the frabulated. 


\title{
SOUTHERN FOOTHILLS-BROOKS RANGE PROVINCE (060)
}

\author{
By Kenneth J. Bird

\section{INTRODUCTION}

The Southern Foothills-Brooks Range province is the southernmost of the three provinces that make up the Alaskan North Slope (fig. 3). This province extends $670 \mathrm{mi}$ from the Chukchi Sea on the west to the Canadian border on the east. Its maximum width is slightly more than $100 \mathrm{mi}$. The western limit fronts on the Chukchi Sea, where the State 3-mile limit forms the seaward boundary. The total area of the province is about $45,000 \mathrm{mi}^{2}$. The North Slope is a Cretaceous and Tertiary foreland basin developed on a Mississippian to Early Cretaceous passive margin; stratigraphy is given in figure 16. The Southern Foothills-Brooks Range province occupies the proximal part of the Brooks Range fold-and-thrust belt. Structure is complex, and deformation involves both foreland basin and pre-foreland basin strata. This province was the last of the North Slope provinces to be explored; the first well was drilled in 1968. Since then, only 14 exploratory wells have been drilled by industry and government, resulting in the discovery of two noncommercial gas fields, the sizes of which remain confidential. Two plays were individually assessed: Thrust Belt West and Thrust Belt East. 
REGION 1, ALASKA; REGION 2, PACIFIC COAST

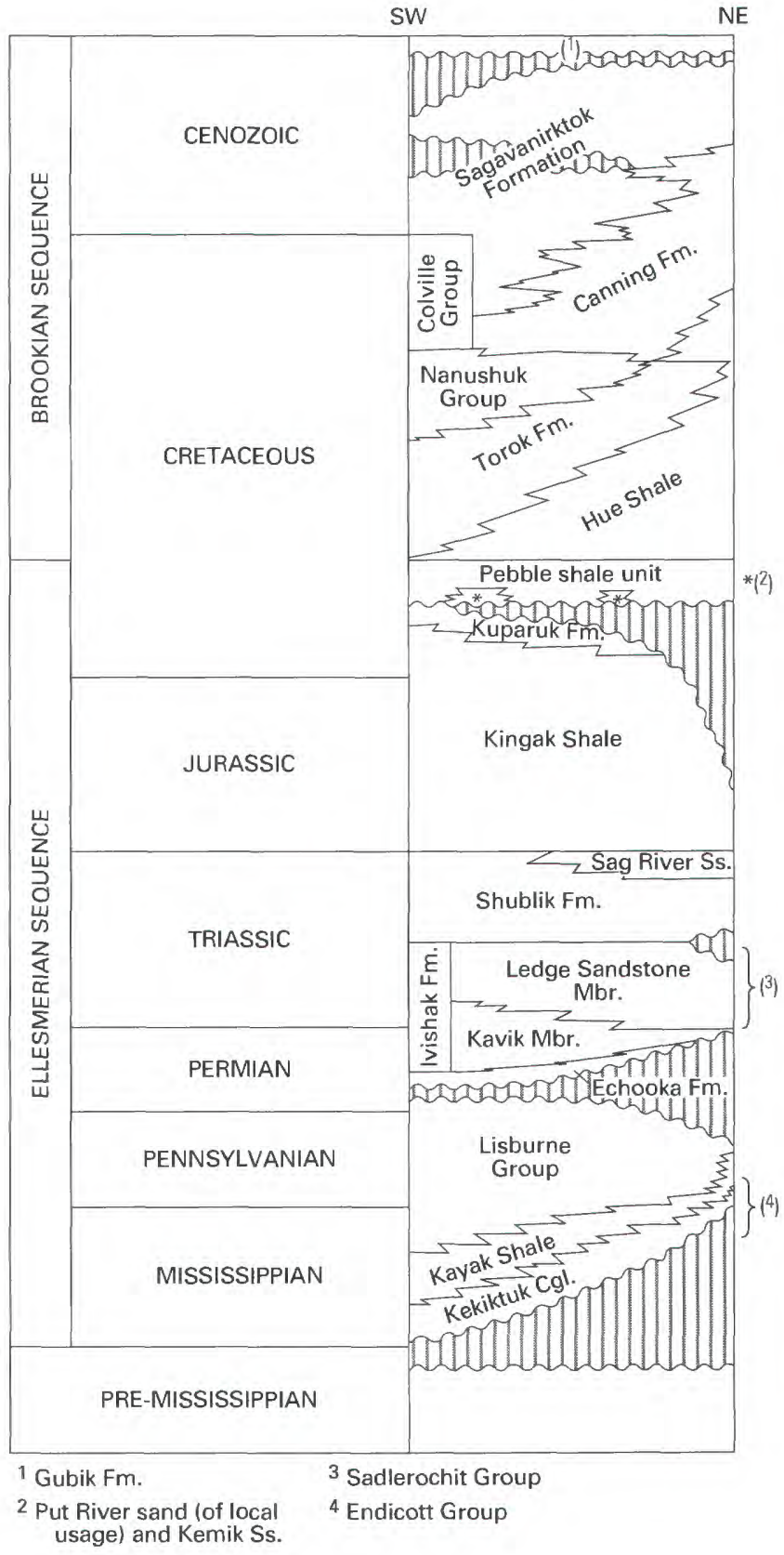

Figure 16. Generalized stratigraphic column, Southern Foothills-Brooks Range province (060). 


\section{THRUST BELT WEST PLAY (020)}

The Thrust Belt West play consists primarily of structural traps in Mississippian carbonate reservoirs in the Brooks Range thrust belt. The northern boundary of the play, guided by seismic reflection data within the NPRA, is drawn far enough north to encompass all the estimated occurrences of thrust sheets of carbonate rocks of the Lisburne Group. The southern boundary is arbitrarily placed about $30 \mathrm{mi}$ into the Brooks Range. The area farther south is expected to have negligible petroleum potential based on the observed southward increase in the level of thermal maturity. The western play boundary is the State 3-mile limit in the Chukchi Sea. The eastern boundary is a short distance east of the Trans-Alaska Pipeline, where the structural style changes (fig. 17). Greatest potential for petroleum in the Thrust Belt West play is expected to be along the immediate range front and the foothills to the north. The thickness of rocks in the play may exceed $20,000 \mathrm{ft}$.

Lisburne Group carbonate rocks are the primary reservoir rock. Other potential reservoir rocks include graywacke sandstone of Jurassic and Cretaceous age and fractured chert and siliceous shale of Mississippian to Jurassic age. The structural style of potential prospects and the physical nature of potential reservoir rocks are exemplified by the Lisburne-1 well, which encountered five thrust repetitions of the Lisburne Group (fig. 16). Each repetition is about $1,200 \mathrm{ft}$ thick, and each has some intervals with indicated porosity in the $10-15$ percent range.

Potential source rocks include marine shale units of Mississippian to Cretaceous age. Oil shale of Mississippian, Triassic, and Jurassic age is known to occur, but these units are considered representative of local occurrences and not characteristic of the entire play. Preliminary data from the Lisburne-1 well (fig. 17) indicate that Triassic and Jurassic rocks are fair to good source rocks. Most source rocks are expected to be mature to overmature, although the data are sparse and the geologic relationships complex. Pyrobitumen (dead oil) appeared in the Lisburne well along with minor indications of gas. Veins of bitumen are known from outcrop localities.

Traps in the play are large anticlinal structures composed of multiple thrust sheets of carbonate rocks. Shale beds within the play are expected to provide fair to good seals, although their effectiveness may be reduced by faulting and related fracturing. Only four exploratory wells have been drilled in the entire play area; information on three of the four remains proprietary. Large, untested structures remaining in the play may number in the dozens. Future potential appears good for oil and excellent for gas. 
REGION 1, ALASKA; REGION 2, PACIFIC COAST

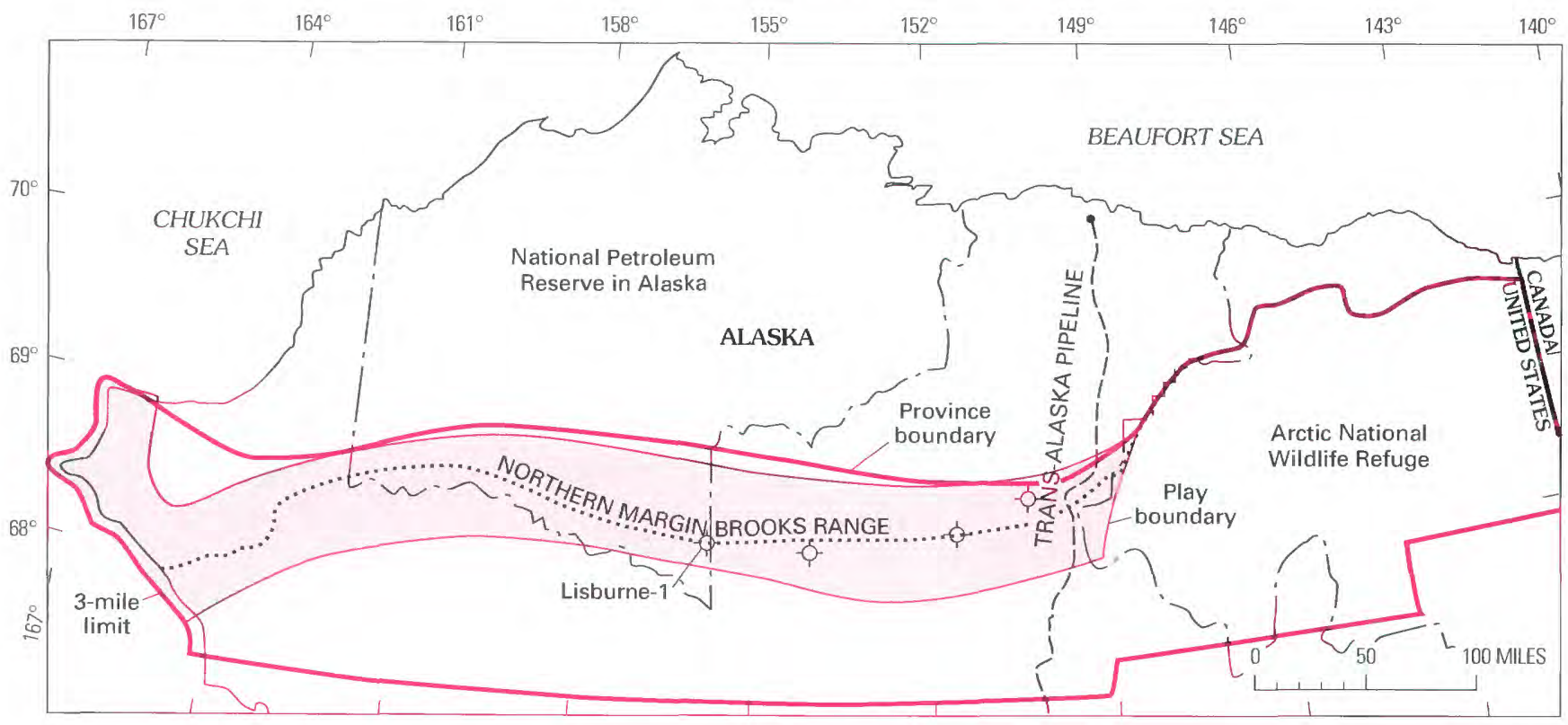

Figure 17. Map of Thrust Belt West play (060-020), showing four exploratory wells.

OIL AND GAS PLAY DATA

PLAY THRUST BELT WEST

PROVINCE SOUTHERN FOOTHILLS-BROOKS RANGE CODE 01-060-020

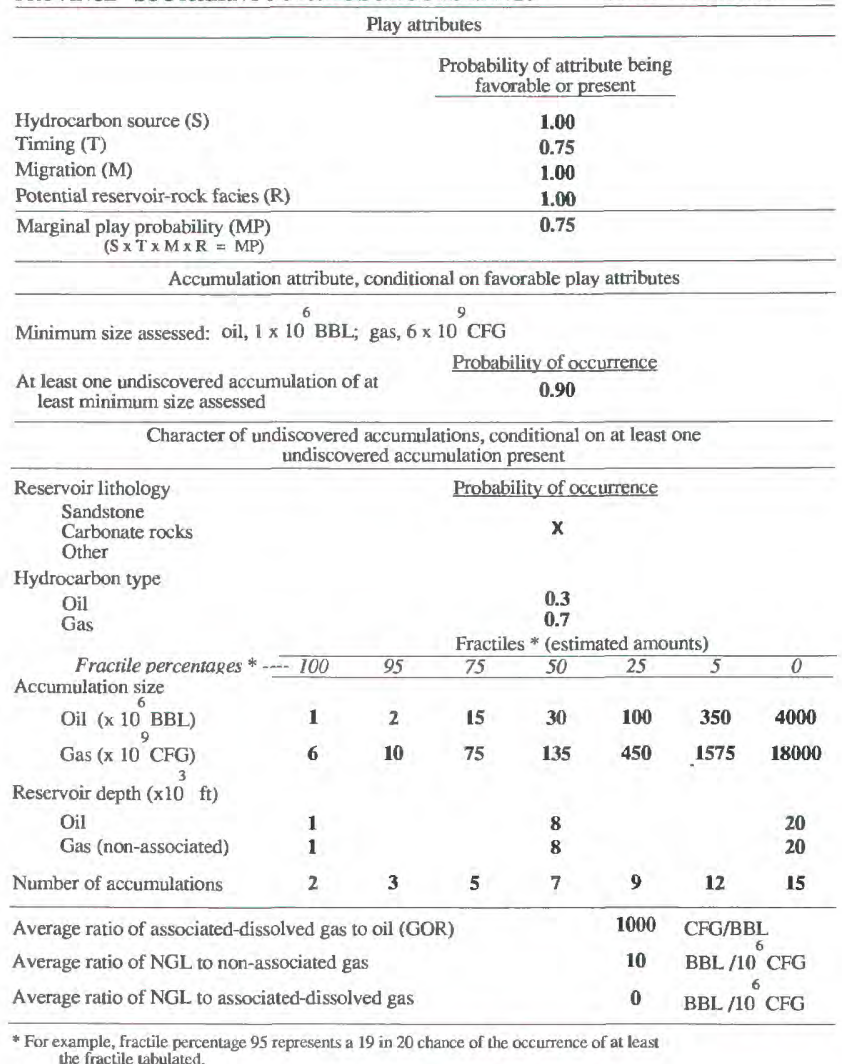




\section{THRUST BELT EAST PLAY (030)}

The Thrust Belt East play consists primarily of structural traps in carbonate and clastic reservoirs of the Ellesmerian and pre-Mississippian sequences in the Brooks Range thrust belt. The northern boundary of the play, guided by seismic reflection data within the ANWR, is drawn far enough north to encompass all the estimated occurrences of thrust blocks of Ellesmerian and older rocks. The southern boundary is arbitrarily placed about $30 \mathrm{mi}$ into the Brooks Range. The area farther south is expected to have negligible petroleum potential, based on the observed southward increase in the level of thermal maturity. The eastern one-third of the play extends offshore to the State 3-mile limit in the Beaufort Sea. The western boundary lies a short distance east of the Trans-Alaska Pipeline, where the structural style changes (fig. 18). In general regional terms, the Thrust Belt East play lies structurally beneath the Fold Belt East play of province 059. Greatest potential for petroleum in the Thrust Belt East play is expected to be north of the Brooks Range front, beneath the foothills and coastal plain of the ANWR.

The most important reservoir rocks are expected to be carbonate rocks of the Lisburne Group, although other Ellesmerian reservoir rocks, such as the Sadlerochit Group, may be of nearly equal importance in the northern parts of the play. Part or all of the Ellesmerian sequence may be missing from structures in the northernmost part of the play because of erosional truncation by the regional Lower Cretaceous unconformity. Pre-Mississippian-Pennsylvanian carbonate rocks are also considered potential reservoirs. Depth to these reservoir rocks ranges from near-surface to greater than $20,000 \mathrm{ft}$.

Potential source rocks include a continuous section of organic, carbon-rich marine shales that primarily range in age from Middle Triassic to Late Cretaceous (Shublik Formation, Kingak Shale, pebble shale unit, and Hue Shale). Thermal maturity decreases northeastward across the play, ranging from mature and overmature in the southwest to mature and submature in the northeast. Minor oil staining in sandstone and carbonate rock is known from wells and outcrop, and two subeconomic gas accumulations, Kemik and Kavik, have been discovered.

Traps are broad, thrust-faulted anticlinal structures that involve Ellesmerian and pre-Mississippian basement rocks, and typically produce only a single repetition of the stratigraphic section. Stratigraphic traps, such as updip pinchouts on the flanks of anticlines, may also be present. Shales, including those in the basal part of the Brookian sequence, are expected to provide fair to good seals, although their effectiveness may be reduced by faulting and related fracturing. Ten exploratory wells have tested eight structures; at least several dozen structures still remain to be tested. Estimates of oil and gas resources in this play have been apportioned 66 percent to the Arctic Coastal Plain province (058), 30 percent to the Northern Foothills province (059), and 4 percent to the Southern Foothills-Brooks Range province (060). Future potential for both oil and gas is excellent. 
REGION 1, ALASKA; REGION 2, PACIFIC COAST

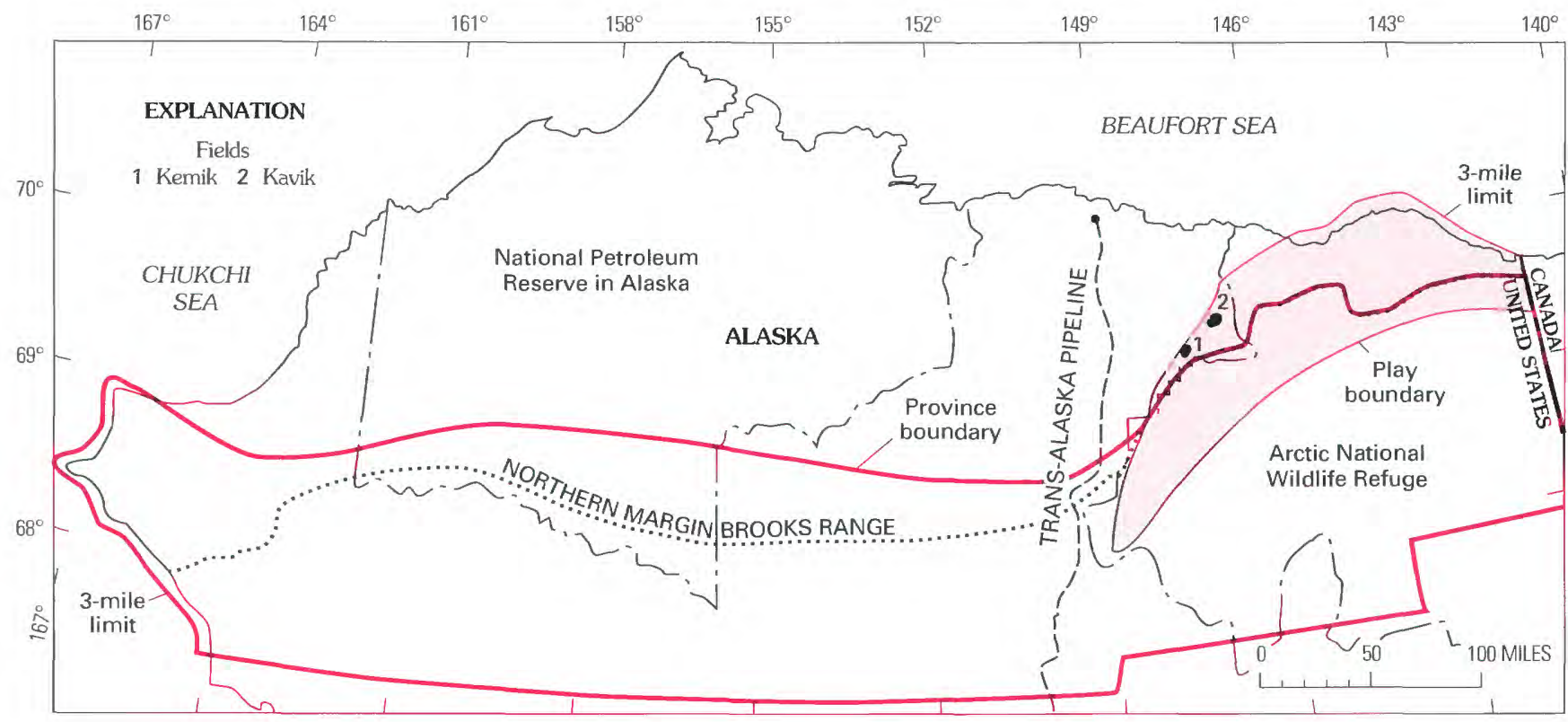

Figure 18. Map of Thrust Belt East play (060-030). Fields numbered and labeled.

OIL AND GAS PLAY DATA

PLAY THRUST BELT EAST

PROVINCE SOUTHERN FOOTHILLS - BROOKS RANGE CODE 01-060-030

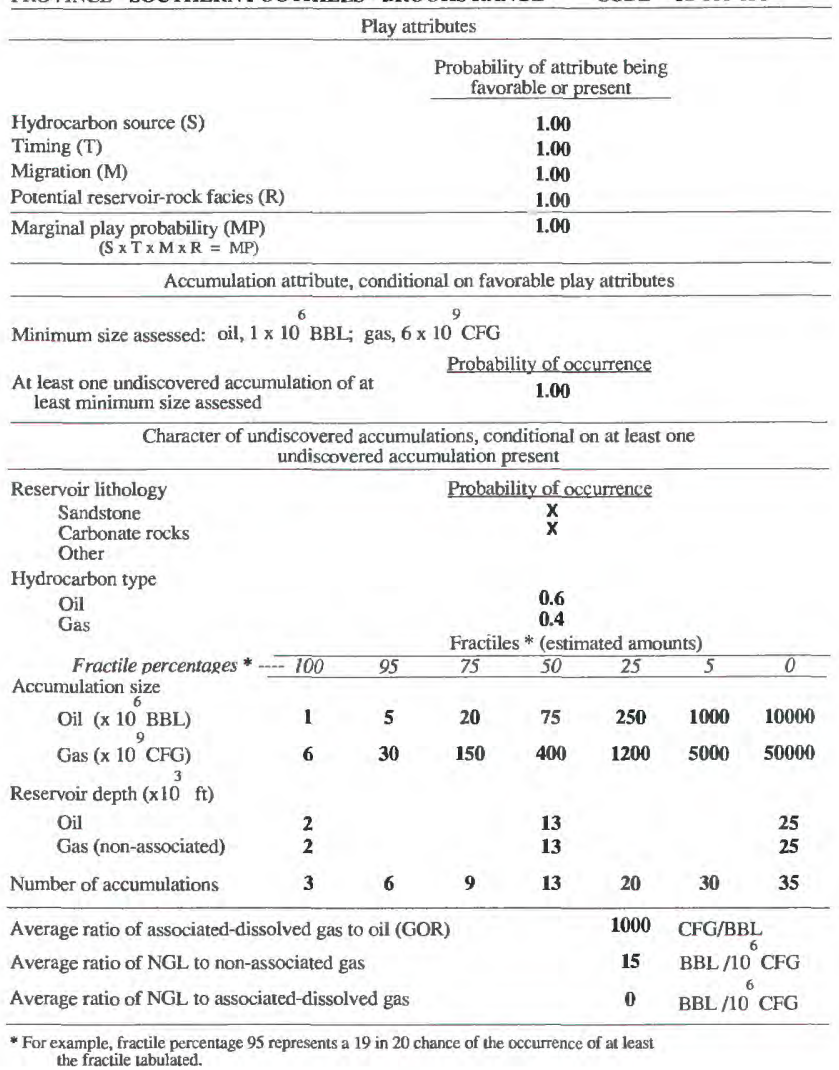




\title{
KANDIK PROVINCE (061)
}

\author{
By Leslie B. Magoon
}

\section{INTRODUCTION}

The Kandik province lies in east-central Alaska (fig. 3) adjacent to Yukon Territory in Canada and covers an area of $42,500 \mathrm{mi}^{2}$. Most of the province, the Yukon Flats basin, is covered by Quaternary alluvium (stratigraphic column, fig. 19). This area was assessed as part of the Tertiary Basins play, which is common to four provinces (see Alaska Interior province 062). The area straddles the drainages of the Yukon and Porcupine Rivers and lies north of the Yukon-Tanana crystalline highlands and south of the Brooks Range (fig. 20). The east-central part of the province is considered to be part of the greater Cordilleran thrust belt of western Canada and the United States; this area was defined and assessed as the Cordilleran Thrust play (040). All exploratory drilling in the province (three wells) has been conducted in the Cordilleran Thrust play. These wells, all drilled during the 1970 's, found no commercial hydrocarbons. 
REGION 1, ALASKA; REGION 2, PACIFIC COAST

\begin{tabular}{|c|c|}
\hline AGE & UNIT \\
\hline $\begin{array}{c}\text { TERTIARY } \\
-------- \\
\text { CRETACEOUS }\end{array}$ & Sandstone, mudstone, and conglomerate \\
\hline JURASSIC & \multirow[t]{2}{*}{ Glenn Shale } \\
\hline TRIASSIC & \\
\hline PERMIAN & Tahkandit Limestone \\
\hline PENNSYLVANIAN & \\
\hline \multirow{2}{*}{ MISSISSIPPIAN } & \\
\hline & Ford Lake Shale \\
\hline \multirow[t]{2}{*}{ DEVONIAN } & Nation River Formation \\
\hline & McCann Hill Chert \\
\hline SILURIAN & Road River Formation \\
\hline ORDOVICIAN & Hillard Limestone \\
\hline \multirow[b]{2}{*}{ CAMBRIAN } & Adams Argillite \\
\hline & Funnel Creek Limestone \\
\hline PRECAMBRIAN & Tindir Group \\
\hline
\end{tabular}

Figure 19. Generalized stratigraphic column, Kandik province (061). 


\section{CORDILLERAN THRUST PLAY (040)}

The Cordilleran Thrust play (fig. 20) is structural and is characterized by thrustfaulted anticlines affecting clastic and carbonate reservoirs of Paleozoic, Mesozoic, and Tertiary age. The east edge of the play coincides with the Canadian border. The play area is part of the greater Cordilleran thrust belt and is truncated on the southwest by the Tintina fault, an important right-lateral shear. The structural grain of the thrust belt trends northeastward and the direction of thrusting southeastward.

Potential reservoirs include Devonian turbidite sandstone units of the Nation River Formation, Mississippian and Pennsylvanian carbonate turbidites of the Calico Bluff Formation, shallow marine limestone of the Permian Tahkandit Limestone, and unnamed sandstone units of Cretaceous and Tertiary age (fig. 19). Reservoir properties are not known for these units.

Potential source rocks include marine shale in the Late Paleozoic Ford Lake Shale and Calico Bluff Formation, and the Mesozoic Glenn Shale. The organic matter included in these units is of marine origin, and is either thermally mature or overmature. Three wildcat wells have been drilled in the play, with a minor "dead" oil show reported in one well. Active seeps are unknown, but a petroleum odor is conspicuous in the Calico Bluff section on the Yukon River.

Anticipated traps are thrust-related folds. Adequate seals in the form of shale and siltstone cover the anticipated siliciclastic sandstone and carbonate reservoirs. Drill depths range from 1,000 to $15,000 \mathrm{ft}$. The future petroleum potential of the play is estimated to be moderate. 
REGION 1, ALASKA; REGION 2, PACIFIC COAST

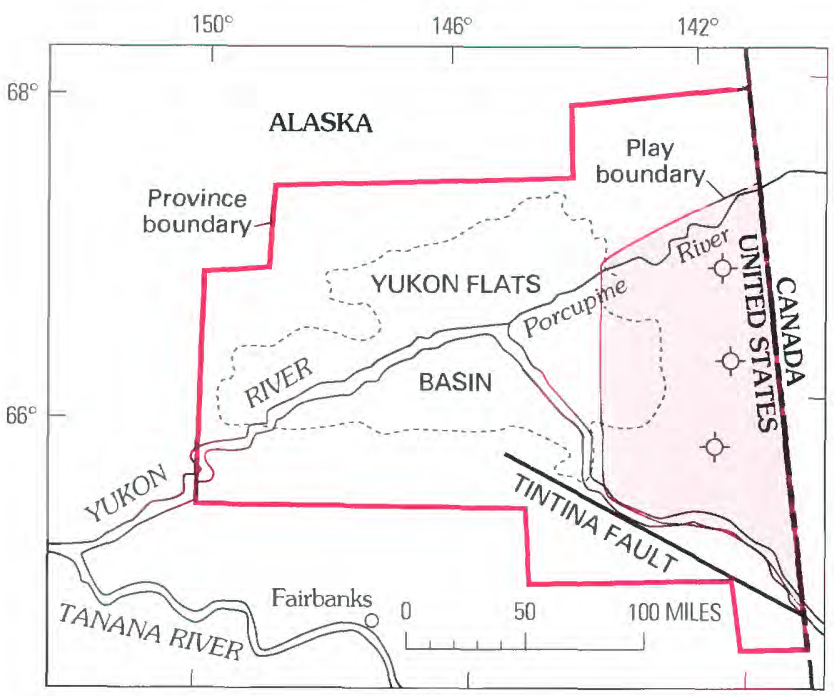

Figure 20. Map of Cordilleran Thrust play (061-040), showing three (dry hole) exploratory wells.

OIL AND GAS PLAY DATA

PLAY CORDILLERAN THRUST PROVINCE KANDIK CODE 01-061-040

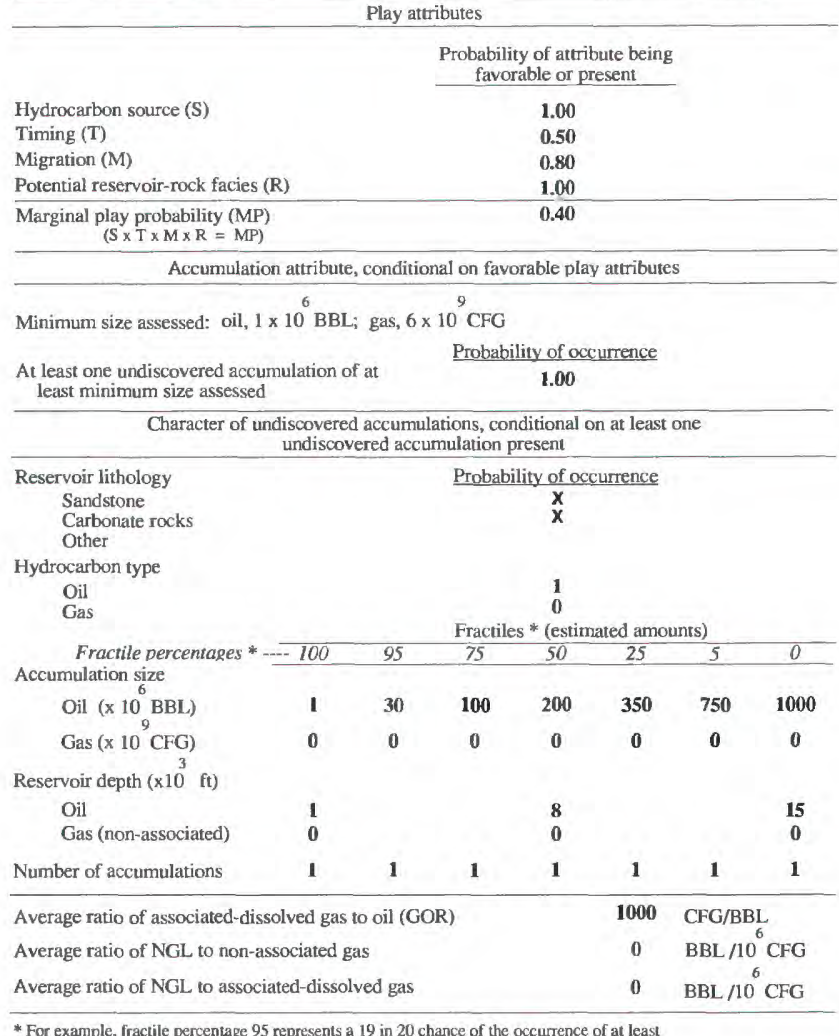

example, fractile percen
the fractile tabulated. 


\title{
ALASKA INTERIOR (062), KANDIK (PART) (061), INTERIOR LOWLANDS (063), AND COPPER RIVER BASIN (066) PROVINCES
}

\author{
By Leslie B. Magoon
}

\section{INTRODUCTION}

The four contiguous provinces that make up the interior part of Alaska are the Kandik (061), Alaska Interior (062), Interior Lowlands (063), and Copper River Basin (066) provinces. They lie south of the Brooks Range and north of the provinces bordering the Pacific Ocean, and extend from the Canadian border on the east to the Bering Sea on the west. The provinces are characterized by numerous mountain ranges and low-relief uplands composed of Precambrian to Cenozoic igneous and metamorphic rocks, which are separated by broad, alluviated lowlands (fig. 21). Some parts of the lowland areas are underlain by Cenozoic nonmarine sedimentary basins, as indicated by negative gravity anomalies, a few exploratory wells, and limited surface exposures. At least 10 such basins are present (fig. 22).

Common characteristics of these Cenozoic basins are the following: (1) the sedimentary fill is less dense than the surrounding rocks, and therefore, the basins are reflected as distinct gravity lows; (2) the fill consists mainly of nonmarine fluvial and coal-bearing sedimentary rocks deposited in numerous fining-upward sequences; (3) a pattern of three cycles of sedimentation appears to be present-an early cycle of Paleocene to early Eocene age, a middle cycle of late Eocene to late Miocene age, and a late cycle of late Miocene and Pliocene age; (4) the depocenter for each younger cycle is commonly displaced from the preceding cycle as a result of deformation and uplift; and (5) structure is commonly extensional, but folding related to thrust faulting, highangle reverse faulting, or transpression by dextral faulting is also recognized.

Only 12 exploratory wells have been drilled in these interior provinces-2 each in the Bethel and Nenana basins and 8 in the Copper River basin. Only minor gas indications were reported. Because of the apparent similarities of the interior Alaskan basins, they were grouped together and assessed as a single play, the Tertiary Basins play. 
REGION 1, ALASKA; REGION 2, PACIFIC COAST

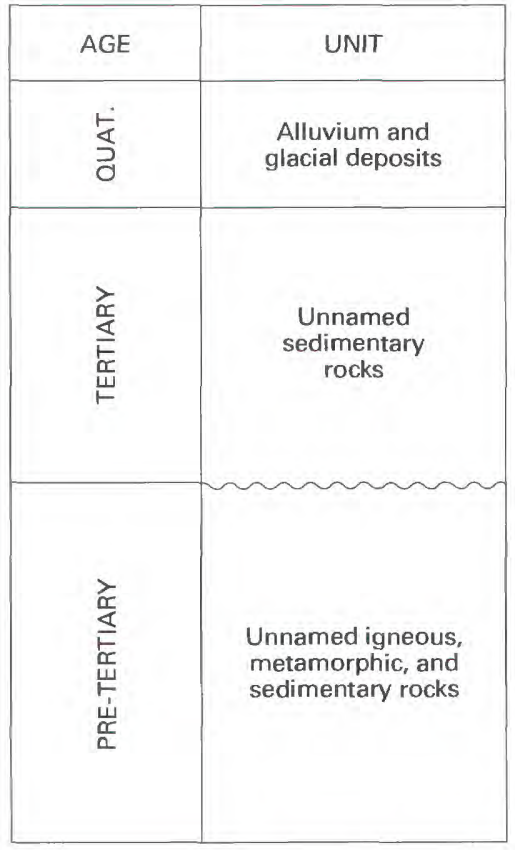

4 Figure 21. Generalized stratigraphic column for Alaska Interior (062), Kandik (part) (061), Interior Lowlands (063), and Copper River Basin (066) provinces. 


\section{TERTIARY BASINS PLAY (020)}

The Tertiary Basins play is characterized by speculative gas accumulations in structural (mainly domal) traps in sandstone reservoirs of Tertiary age. The BelugaSterling play in the Cook Inlet province (067) is considered to be an analog for the play, in that expected gas would be primarily microbial in origin, but would include minor amounts of thermally generated gas. The Tertiary Basins play includes those basins in the four provinces that are filled with Tertiary sediments (fig. 22). Expected source rocks are coal, or rocks containing closely associated humic kerogen (Type III). Shale and siltstone that overlie the sandstone reservoirs would provide adequate seals.

Reservoirs include nonmarine fluvial channel sandstones similar to those known in the analog Tertiary Beluga and Sterling Formations. Sandstone reservoirs in these formations have water saturations that range from 35 to 50 percent, porosities that range from 10 to 37 percent, and permeabilities that range from 3.5 to 4,400 millidarcies. Thickness of net pay ranges from 20 to $213 \mathrm{ft}$.

Because overburden is not required to create microbial gas from source rocks, undiscovered gas accumulations may be found wherever a thin but adequate seal rock in a trapping situation exists. Additional thermogenic gas may be present in basins with sedimentary fill greater than $10,000 \mathrm{ft}$ thick. The future gas potential, at least for local usage, is estimated to be fair to good.

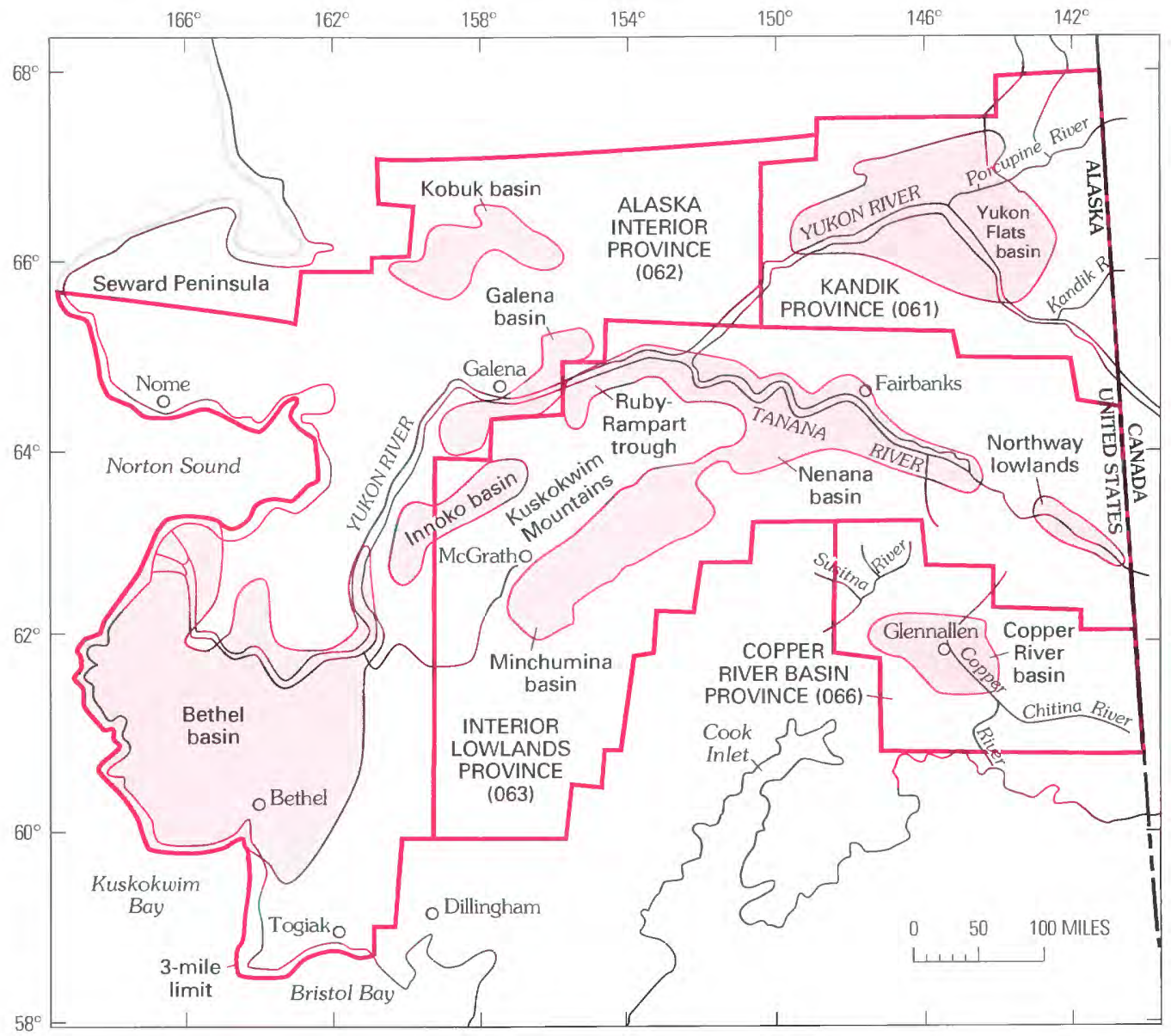

Figure 22. Map of Tertiary Basins play (020) in provinces 061, 062, 063, and 066. 
REGION 1, ALASKA; REGION 2, PACIFIC COAST

OIL AND GAS PLAY DATA

PLAY TERTIARY BASINS

PROVINCE ALASKA INTERIOR

Play attributes

CODE $\quad 01-062-020$

Probability of attribute being

favorable or present

Hydrocarbon source (S)

Timing (T)

1.00
1.00

Migration (M)

1.00

Marginal play probability (MP)

1.00

Accumulation attribute, conditional on favorable play attributes

Minimum size assessed: oil, $1 \times 10^{6} \mathrm{BBL}$; gas, $6 \times 10^{9} \mathrm{CFG}$

At least one undiscovered accumulation of at Probability of occurrence

At least one undiscovered accumulation of at
least minimum size assessed

Character of undiscovered accumulations, conditional on at least one undiscovered accumulation present

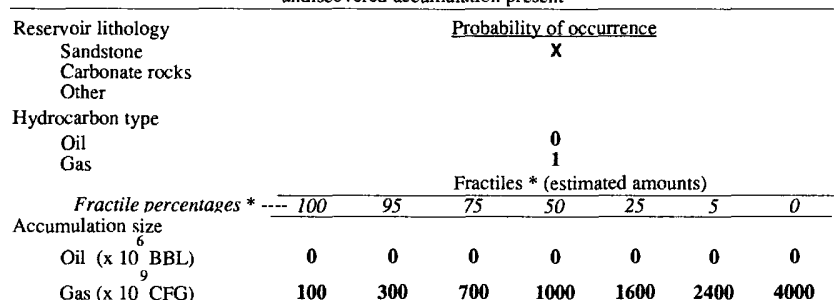

Reservoir depth $\left(\mathrm{x} 10^{3} \mathrm{ft}\right)$

Gas (non-associated)

Number of accumulations

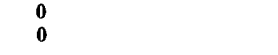

Average ratio of associated-dissolved gas to oil (GOR)

Average ratio of NGL to non-associated gas

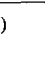

0 10

Average ratio of NGL to associated-dissolved gas

$0 \quad \mathrm{CFG} / \mathrm{BBL}$

$0.06 \mathrm{BBL} / 10^{6} \mathrm{CFG}$

- BBL $/ 10^{6} \mathrm{CFG}$

* For example, fractile percentage 95 represents a 19 in 20 chance of the occurrence of at least
the fractile tabulated. 


\title{
BRISTOL BASIN PROVINCE (064)
}

\author{
By Leslie B. Magoon
}

\section{INTRODUCTION}

The Bristol Basin province is elongate in configuration and fringes Bristol Bay, covering about $25,000 \mathrm{mi}^{2}$ in area. The province extends $500 \mathrm{mi}$ from Unimak Island on the southwest to Illiamna Lake in the northeast. Part of it borders the Alaska Peninsula province (068) and Pacific Ocean on the southwest, the Cook Inlet province (067) on the east, and the Alaska Interior province (062) on the north (fig. 3).

The province includes part of the Alaska Peninsula fold belt-a broadly folded sequence of mostly Mesozoic sedimentary and volcanic rocks (fig. 23) more than $20,000 \mathrm{ft}$ thick - and the onshore part of the Tertiary Bristol basin. The Bristol basin and contiguous North Aleutian basin are back-arc basins that began to form in early Tertiary time and were filled with more than $12,000 \mathrm{ft}$ of mostly marine siliciclastic sediment. Basin fill was probably derived from the Aleutian volcanic arc to the south and from the complex of igneous, metamorphic, and sedimentary rocks that make up the southwest part of Alaska, located to the north and northeast of the basin. The lower Tertiary section consists of coal-bearing sandstone and mudstone, the Eocene part of which is volcaniclastic. The upper Tertiary part of the section consists of shallow marine to nonmarine coal-bearing sandstone and mudstone grading upward to nonmarine sand and gravel.

Sporadic exploration has been conducted in the province since 1959 with the drilling of 11 wells, 9 of which are located in the Bristol basin (fig. 24). The most recent well was drilled in 1985. Indications of gas are reported in some wells with minor oil indications in early Tertiary and pre-Tertiary rocks. No hydrocarbon accumulations have been found. One play, the Tertiary play, was individually assessed. 
REGION 1, ALASKA; REGION 2, PACIFIC COAST

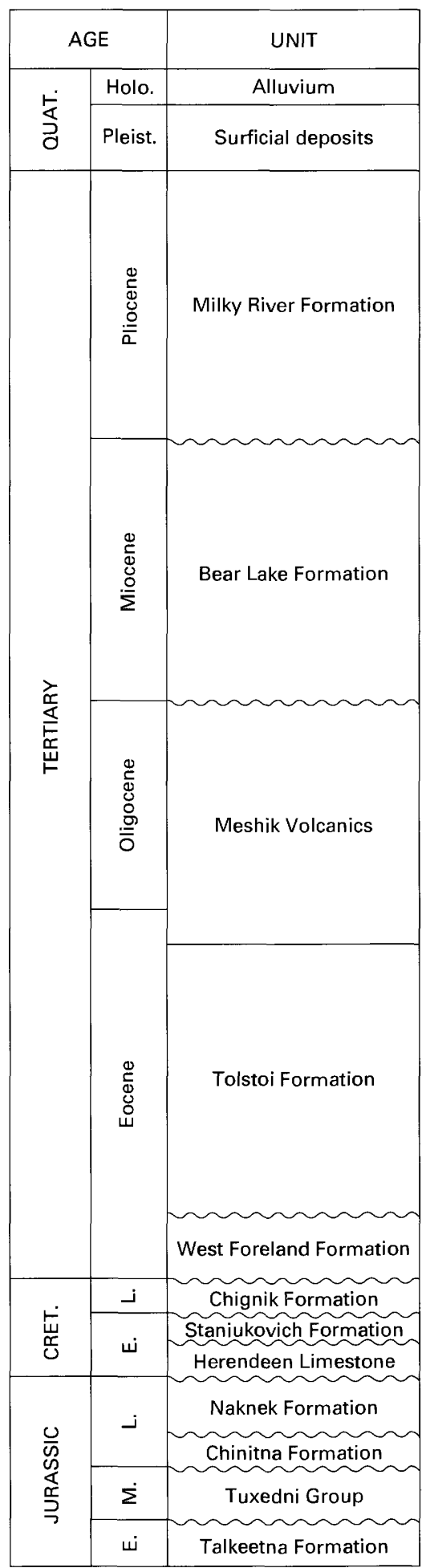

Figure 23. Generalized stratigraphic column, Bristol Basin province (064). 


\section{TERTIARY PLAY (020)}

The Tertiary play involves structural (mainly domal) traps for gas in sandstone reservoirs of Tertiary age. The Beluga-Sterling play in the Cook Inlet province (067) is an analog for the play, because the expected gas is primarily microbial in origin with only minor amounts of thermal gas. The play includes only those areas that are covered by Tertiary sediments. Expected source rocks for the play are sediments containing coal or humic kerogen (Type III). Adequate seals are shale and siltstone that overlie the sandstone reservoirs.

Reservoirs may include nonmarine sandstone units similar to those in the Beluga and Sterling Formations as well as some shallow marine sandstone. The analog reservoirs have water saturations of 35-50 percent, porosities of 10-37 percent, and permeabilities of 3.5-4,400 millidarcies. Net pay thickness ranges from 20 to $200 \mathrm{ft}$.

Because overburden is not required to create microbial gas from source rocks, undiscovered gas accumulations may be found wherever thin but adequate seal rock exists in association with reservoirs in a trapping condition. In addition, thermogenic gas is from humic or coaly source rocks, the anticipated type of sediments in the play, at depths greater than $10,000 \mathrm{ft}$. The future gas potential is estimated to be fair. 
REGION 1, ALASKA; REGION 2, PACIFIC COAST

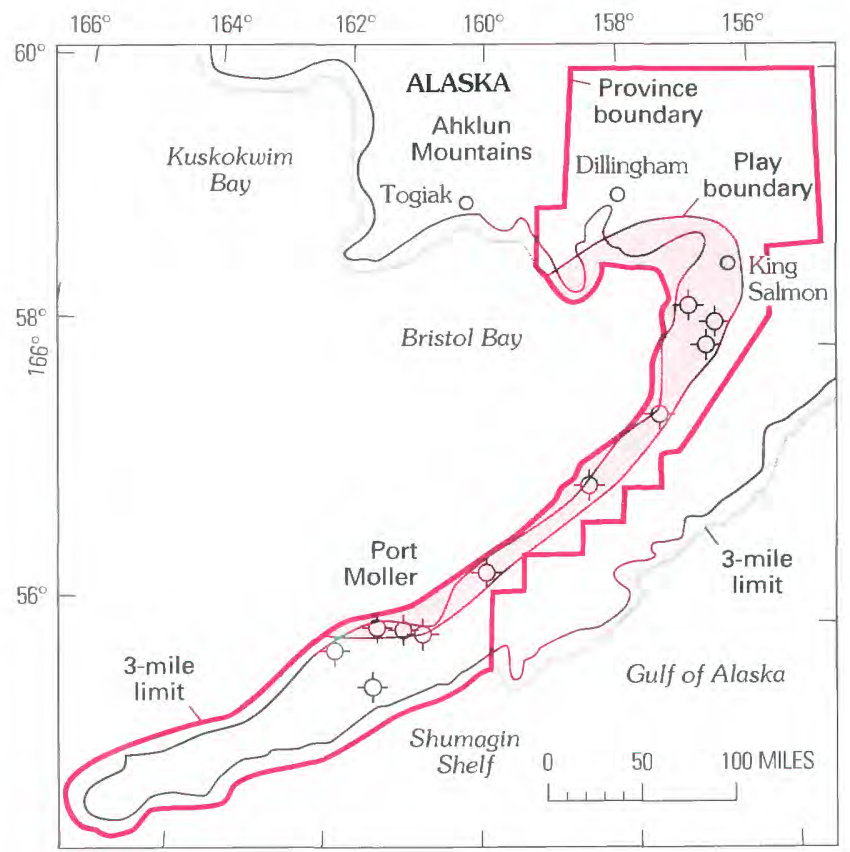

Figure 24. Map of Tertiary play (064-020), showing exploratory wells.

OIL AND GAS PLAY DATA

PLAY TERTIARY

PROVINCE BRISTOL BASIN

CODE 01-064-020

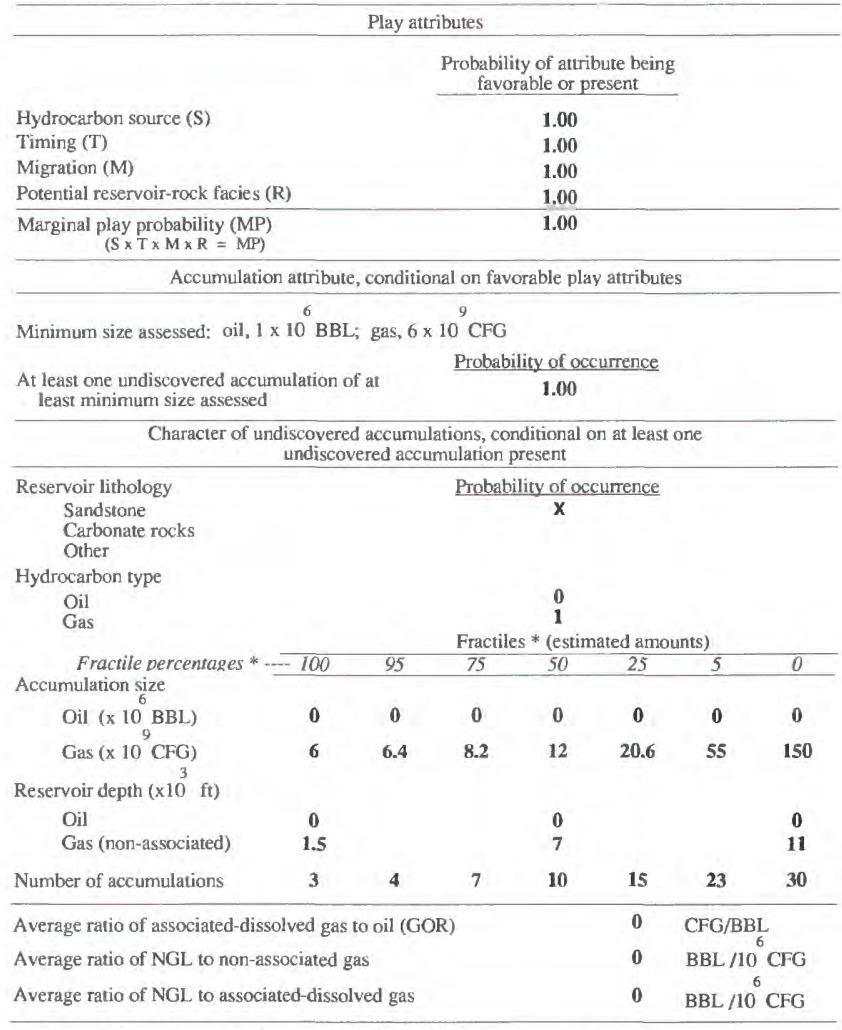

* For example, fractile percentage 95 represents a 19 in 20 chance of the occurrence of at least

the fractile tabulated. 


\title{
HOPE BASIN PROVINCE (065)
}

\author{
By Michael A. Fisher
}

The onshore part of the structural Hope basin lies east and south of Kotzebue Sound, and together with the associated Kotzebue basin, underlies the northern Seward Peninsula and the lowlands that fringe the east and north sides of the Chukchi Sea (fig. 25). The main part of Hope basin lies offshore, where Cenozoic rocks range from 16,000 to $20,000 \mathrm{ft}$ thick. The Hope basin could contain rocks as old as Paleocene, but shoreward parts of the basin include a progressively thinner, younger section.

The Hope Basin province encompasses a land area of $15,600 \mathrm{mi}^{2}$. Two wildcat exploratory wells have been drilled onshore, both by Standard Oil Company of California. The \#1 Nimiuk Point well was spudded in 1974 and reached a total depth of 6,310 $\mathrm{ft}$; the \#1 Cape Espenberg well was spudded in 1975 and reached a total depth of 8,320 $\mathrm{ft}$. Rocks in the Cape Espenberg well are richly volcanogenic from total depth up to about $5,000 \mathrm{ft}$; above $5,000 \mathrm{ft}$, the volcanic fraction decreases, and the section includes much sandstone and shale.

Seismic reflection data show that the sedimentary fill within the overall Hope basin is as thick as $\approx 10,000 \mathrm{ft}$, and the fill thins and onlaps shoreward. In onshore areas, wells and scattered proprietary seismic sections show that probable Cenozoic fill is less than $3,300 \mathrm{ft}$ thick, but thicker $(6,000 \mathrm{ft})$ Cenozoic rocks are present in isolated half-grabens. To search for hydrocarbons with much expectation seems unrealistic except in the areas of the half-grabens; the onshore and nearshore parts of the basins include thin basin fill, most of which is not associated with oil source rocks-if any exist-in the main part of the basin.

The Hope Basin province overlies two types of basement rock: (1) deformed and metamorphosed Paleozoic rocks that crop out on the Seward Peninsula, and (2) strongly deformed Cretaceous turbidite sequences and volcanic rocks, which are exposed east of the province. The Cretaceous volcanogenic turbidite sequences and andesitic volcanic rocks are characterized by poor porosity and permeability, and laumontite completely occludes pore spaces in rocks exposed over large areas.

Rocks as old as Eocene penetrated by the two wells drilled in the Hope Basin province are thermally immature. Pyrolysis data show that these rocks have a poor potential to generate liquid hydrocarbons, because the kerogen is gas prone, primarily Type III, which requires a burial depth of about $5,600 \mathrm{ft}$ to achieve a vitrinite reflectance of 0.6. The sediment fill would need to be at least as thick to generate oil; however, biogenic gas may be present. Both the Paleozoic and the Cretaceous basement rocks penetrated by the wells are thermally overmature and are not likely to be source rocks for hydrocarbons. No plays were identified, and no assessment of resources was made. 
REGION 1, ALASKA; REGION 2, PACIFIC COAST

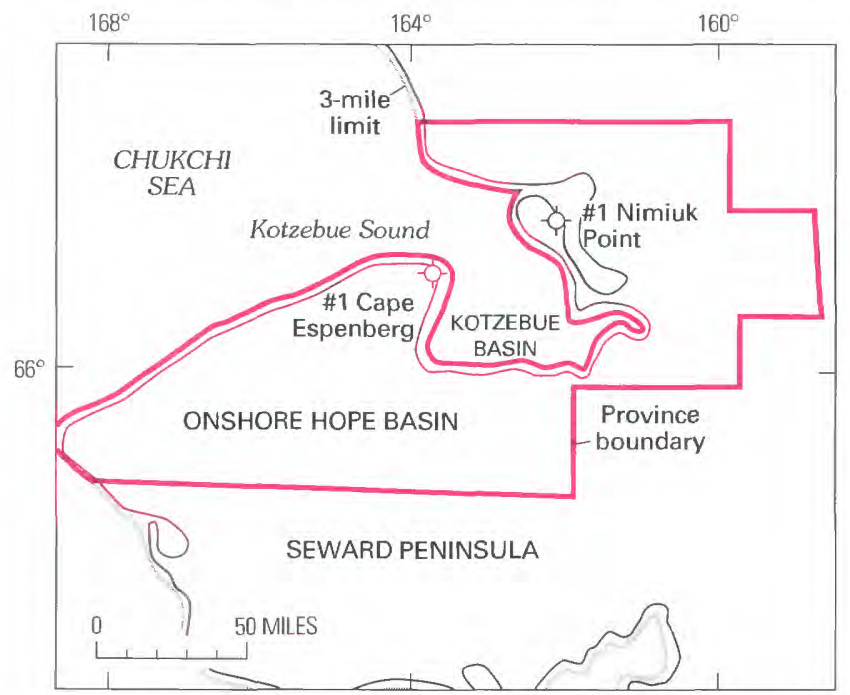

Figure 25. Map of Hope Basin province (065), showing exploratory wells. 


\title{
COOK INLET PROVINCE (067)
}

\author{
By Leslie B. Magoon
}

\section{INTRODUCTION}

The Cook Inlet province is located in southern Alaska (fig. 3) and is $450 \times 270 \mathrm{mi}$ in extent. It comprises several tectonostratigraphic terranes with complex stratigraphy and structure, the result of its position on the tectonically active north Pacific margin. This area has been the site of continuous convergence throughout the Mesozoic and Cenozoic. Its prominent feature, the Cook Inlet embayment, is located in the middle of a Tertiary sedimentary basin, $175 \mathrm{mi}$ long by $70 \mathrm{mi}$ wide, which trends in a northeasterly direction. The Tertiary Cook Inlet basin, bordered on the west and northwest by the Alaska and Aleutian Ranges and on the southeast by the Chugach and Kenai Mountains, is a deep fault-bounded trough filled with nonmarine sedimentary rocks (fig. 26) more than $20,000 \mathrm{ft}$ thick. Oil and gas accumulations are found in sandstone reservoirs in structural traps that formed in Pliocene time. Oil in this province is identified as coming from Jurassic marine shale that lies unconformably beneath the basin. The thick sedimentary fill of the Cook Inlet basin is required to mature these source rocks.

Exploration has been conducted in the province since 1902, when seven wells were drilled into pre-Tertiary rocks on the southwest margin of the basin. The first commercial oil accumulation was not discovered until 1957. During the following 15 years, 7 oil and 23 gas accumulations were discovered. The largest oil field is McArthur River with about $570 \mathrm{MMB}$ of recoverable oil; the largest gas field is Kenai with $2.3 \mathrm{TCF}$ of recoverable gas. By the end of 1986, about $1.1 \mathrm{BBO}$ and $5.3 \mathrm{TCFG}$ had been produced from the basin. Two plays, the Beluga-Sterling and Hemlock Conglomerate, were individually assessed. Most of the area of the province assessed lies in State waters. 
REGION 1, ALASKA; REGION 2, PACIFIC COAST

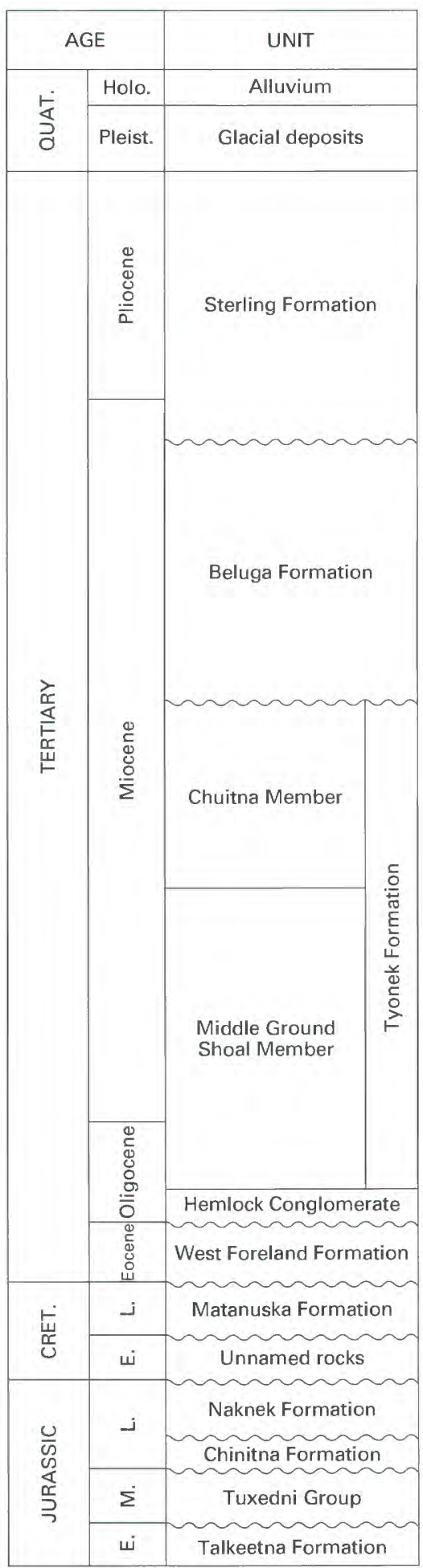

Figure 26. Generalized stratigraphic column, Cook Inlet province (067). 


\section{BELUGA-STERLING PLAY (020)}

In the Beluga-Sterling play, gas accumulated in structural (mainly domal) traps that include siliciclastic reservoirs of Tertiary age. The play is approximately $130 \mathrm{mi}$ long by $50 \mathrm{mi}$ wide (fig. 27). Maximum thickness of sedimentary rocks in the play is $14,000 \mathrm{ft}$.

Known reservoirs include nonmarine fluvial channel sandstones of the Miocene Beluga and Miocene and Pliocene Sterling Formations (fig. 26). These reservoirs have water saturations of 35-50 percent, porosities of 10-37 percent, and permeabilities of 3.5-4,400 millidarcies. Net pay thickness ranges from 20 to $213 \mathrm{ft}$.

The source of the gas is uncertain, but the Beluga Formation and, to a lesser extent, the Sterling Formation contain considerable coal and Type III kerogen. This source is in a good stratigraphic position to charge the overlying reservoirs with microbial gas. Because no overburden is required to mature the source rocks, undiscovered gas accumulations may be found throughout the play.

Traps are expected to be domal structures, and adequate seals exist in the form of shale and siltstone that overlie sandstone reservoirs. Drill depths may be as deep as $10,000 \mathrm{ft}$. Dry gas exceeding 3.1 TCF from 14 fields in the play has been produced to the end of 1986, and an additional 10 fields that are shut-in contain an unknown amount of gas. The largest fields in the play are Kenai and North Cook Inlet. The future gas potential of the play is good. 
REGION 1, ALASKA; REGION 2, PACIFIC COAST

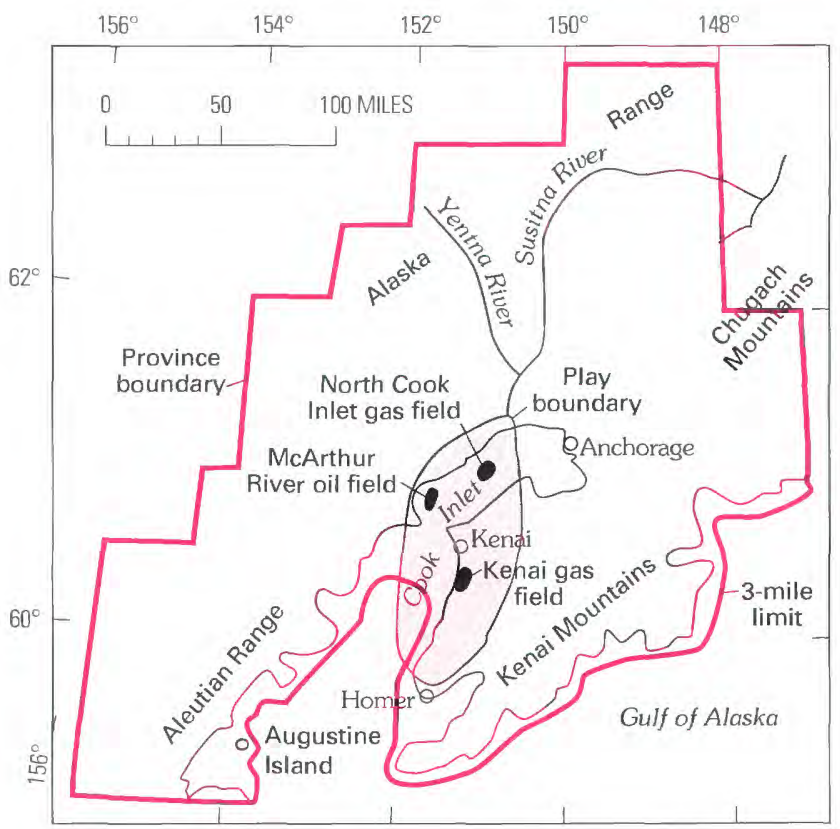

Figure 27. Map of Beluga-Sterling play (067-020).

OIL AND GAS PLAY DATA

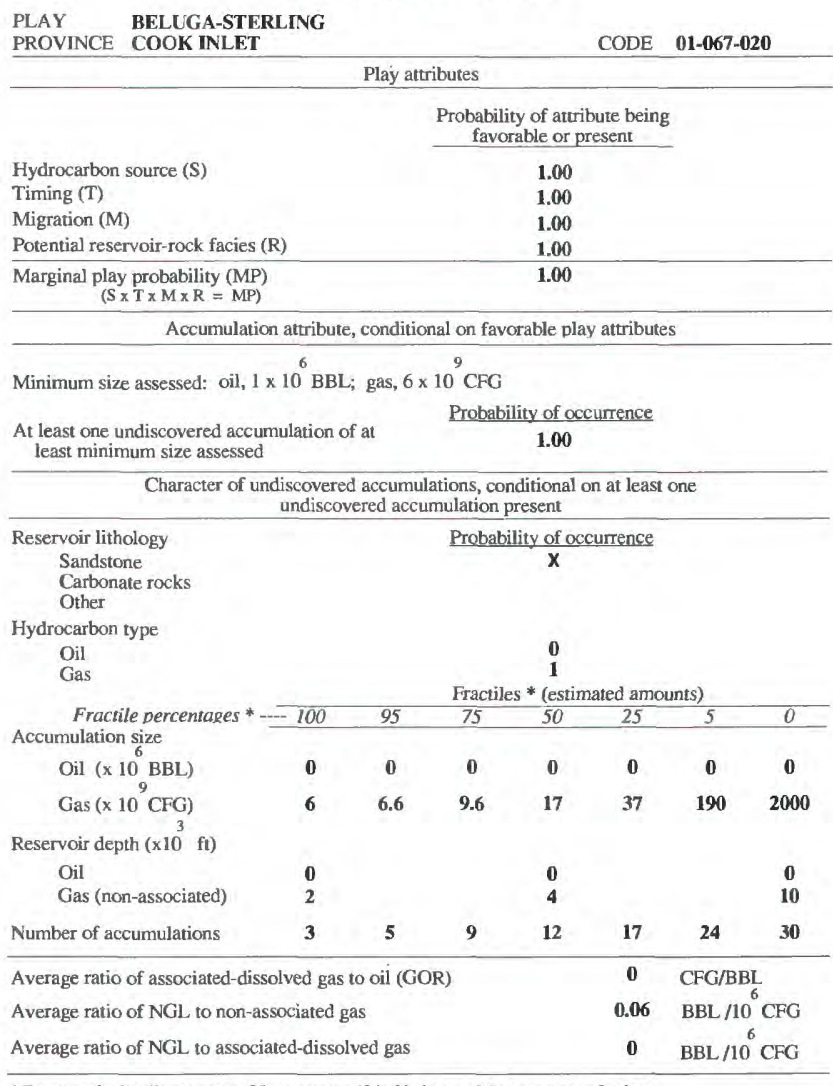

* For example, fractile percentage 95 represents a 19 in 20 chance of the occurrence of at least
the fractile tabulated. 


\section{HEMLOCK CONGLOMERATE PLAY (030)}

The play is structural and involves oil fields that produce from siliciclastic reservoirs of Oligocene age in faulted anticlinal traps. The play is approximately $170 \mathrm{mi}$ long by $50 \mathrm{mi}$ wide, and its area is limited approximately to where Middle Jurassic rocks subcrop beneath Tertiary age reservoir rocks (fig. 28). Maximum thickness of the sedimentary section involved is $8,000 \mathrm{ft}$.

Productive reservoirs include nonmarine sandstone units of the Oligocene Hemlock Conglomerate and Oligocene and Miocene Tyonek Formation (fig. 26). Minor reservoirs include the Upper Cretaceous Matanuska Formation, and the Eocene West Foreland Formation. In these reservoirs, water saturations range from 35 to 40 percent, porosities range from 11 to 24 percent, and permeabilities range from 10 to 360 millidarcies. Net pay thickness ranges from 70 to $1,000 \mathrm{ft}$.

The source of the oil is shale in the Middle Jurassic Tuxedni Group. Organic matter included in the source rock is marine Type II kerogen; the source rock is unconformably overlain by Tertiary reservoir rocks. Throughout the Cook Inlet area, burial depths in excess of $15,000 \mathrm{ft}$ are required to achieve thermal maturation of source rocks. In late Pliocene time the Tuxedni Group was buried deeply enough to generate oil with associated gas that migrated across the unconformity where Tertiary rocks truncate the source rock. Migration and accumulation occurred at the same time, or shortly before anticlinal structures formed. Because some of the oil is in sandstone reservoirs within the Matanuska Formation, it is possible that faults were also migration conduits.

Anticipated traps are probably anticlinal structures and stratigraphic traps of limited areal size. Adequate seals in the form of shale and siltstone cover the sandstone reservoirs. These reservoirs are known to contain oil to depths of $16,000 \mathrm{ft}$, but could contain oil to depths of $18,000 \mathrm{ft}$ because of the very low geothermal gradient. More than 1.17 BBO from five fields in the play has been produced to the end of 1986 , and one additional field that contains an unknown amount of oil is shut-in. The size of the oil fields ranges from $90 \mathrm{MMBO}$ to $570 \mathrm{MMBO}$; however, the future undiscovered potential of the play is low. 
REGION 1, ALASKA; REGION 2, PACIFIC COAST

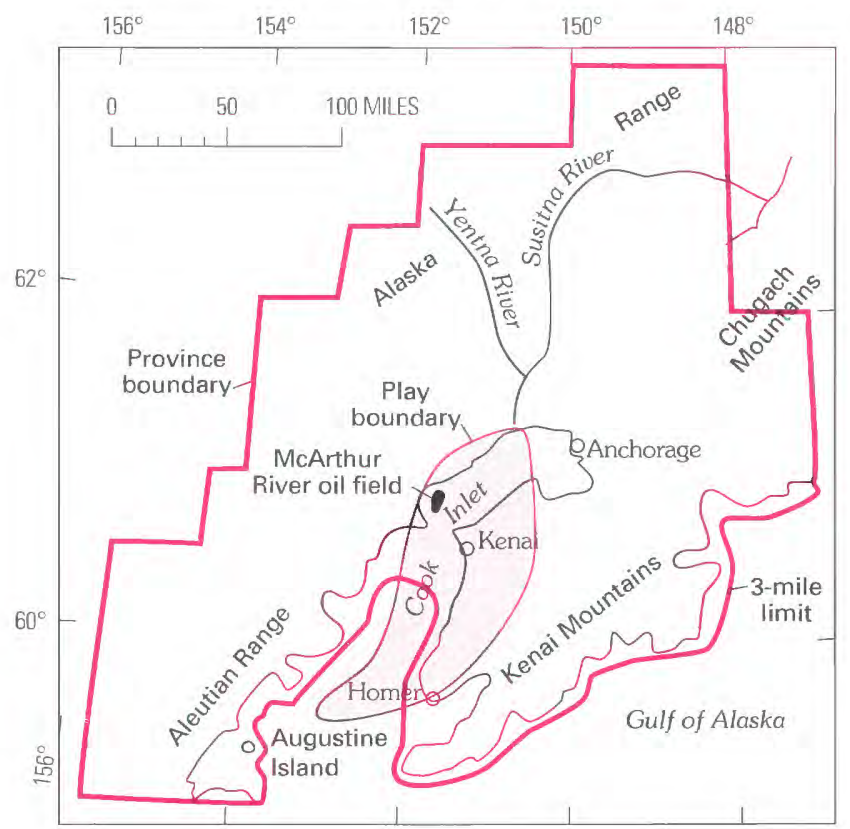

Figure 28. Map of Hemlock Conglomerate play (067-030).

OIL AND GAS PLAY DATA $\begin{array}{ll}\text { PLAY } & \text { HEMLOCK CONGLOMERATE } \\ \text { PROVINCE } & \text { COOK INLET }\end{array}$

Play attributes

CODE 01-067-030

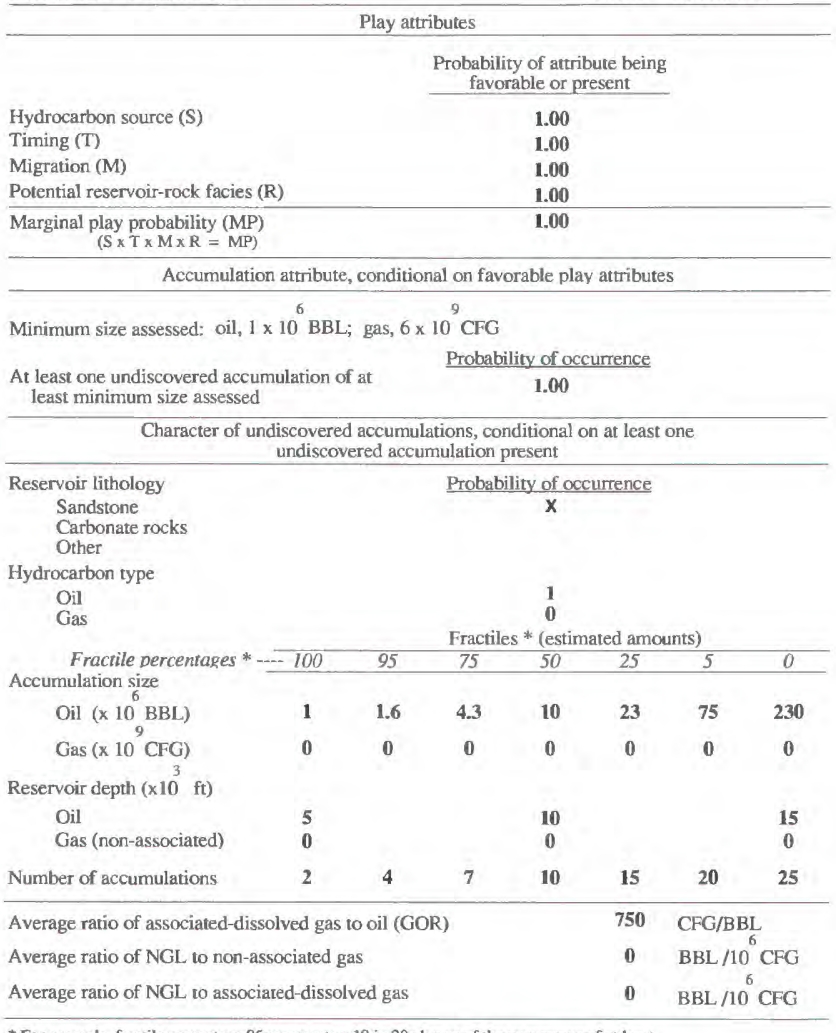

* For example, fracule percentage 95 represents a 19 in 20 chance of the occurrence of at least
the fracile tabulated. 


\title{
ALASKA PENINSULA PROVINCE (068)
}

\author{
By Leslie B. Magoon and Hugh McLean
}

The Alaska Peninsula province is long and narrow and includes the southeastern two-thirds of the Alaska Peninsula, an area of about $12,000 \mathrm{mi}^{2}$. The province extends $320 \mathrm{mi}$ from Kamishak Bay in the northeast to Stepovak Bay on the southwest. The northwestern boundary coincides with the approximate onshore edge of the Tertiary Bristol Basin province. The southeastern boundary is the State-Federal 3-mile offshore boundary in the Pacific Ocean (fig. 3).

The province contains more than $20,000 \mathrm{ft}$ of sedimentary and volcanic rocks of Permian to Quaternary age that are intruded by Jurassic and younger igneous rocks. Mesozoic sedimentary rocks, deformed in broad, open folds, are widely exposed and make up most of the province. Early Cenozoic sedimentary and volcanic rocks generally lie along the margins of the province. Late Cenozoic stratovolcanoes, part of the Aleutian arc, overlie Mesozoic rocks and form a distinctive but relatively minor geologic feature of the province.

Potential reservoir rocks are primarily sandstone of Jurassic, Cretaceous, and Tertiary age; bioclastic limestone of Early Permian and Late Triassic age is of lesser importance. Sandstone units of Early and Middle Jurassic and Tertiary age are generally volcaniclastic with poor reservoir characteristics. Upper Jurassic rocks derived from erosion of a nearby granitic source comprise the thickest and most widespread potential reservoirs. However, petrographic studies show that these rocks are cemented with laumontite and have low conventional porosity. Areas that have not been intruded by large igneous bodies have limited potential due to widespread intrusion of volcanic dikes and sills of late Tertiary and Quaternary age.

Much of the Mesozoic sequence of the Alaska Peninsula contains marine shale and mudstone suitable for both source rocks and seal rocks. Black shale is especially abundant in Late Cretaceous rocks in the southwestern part of the peninsula. The Triassic limestone and chert section at Puale Bay is thermally mature, and, in the same area, oil seeps emanate from Middle Jurassic shale and mudstone. In general, Mesozoic source rocks lie within the window for oil and gas generation, except locally where igneous intrusion renders them overmature.

Most of the broad open folds on the peninsula formed in Pliocene time, which may help explain why the major structures tested by drilling have been dry. By Pliocene time, Mesozoic rocks would have been subjected to diagenesis associated with late Tertiary arc volcanism and plutonism that caused potential reservoirs to be hard and tight and closed potential migration pathways.

The Mesozoic section on the Alaska Peninsula has been sporadically explored without commercial success for nearly 90 years. The earliest exploration effort, in 1904, consisted of several shallow wells drilled near oil seeps. The six deep test wells in the province (fig. 29) were drilled on large-scale structures between 1940 and 1981; indications of oil and gas were encountered in several of these wells. The most recent wildcat, Chevron's Koniag No. 1, was drilled in 1981 on the Pacific Coast side of the peninsula near Amber Bay. Prospects for drilling additional wells on the Alaska Peninsula should be viewed with guarded optimism. No assessment of resources was made for this province. 
REGION 1, ALASKA; REGION 2, PACIFIC COAST

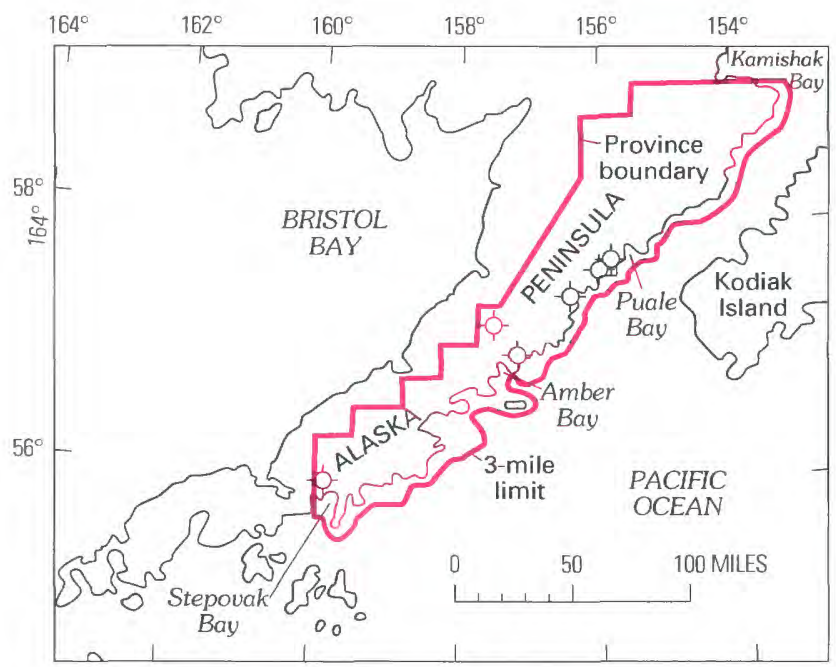

Figure 29. Map of Alaska Peninsula province (068), showing six deep test wells. 


\title{
GULF OF ALASKA PROVINCE (069)
}

\author{
By Terry R. Bruns \\ INTRODUCTION
}

The Gulf of Alaska province stretches about $350 \mathrm{mi}$ from Prince William Sound on the west to Lituya Bay on the east. It extends seaward from lat $61^{\circ} \mathrm{N}$. and the Canada/United States border and includes Middleton Island and State waters $3 \mathrm{mi}$ seaward of the shoreline (fig. 3). Sedimentary rocks with hydrocarbon potential are exposed in a band as much as $6 \mathrm{mi}$ wide along the shoreline near Lituya Bay. These rocks have been sampled in exploratory wells near Yakutat Bay and beneath the adjacent coastal plain east of Yakutat Bay, and crop out in an area as much as 45 mi wide of the coastal plain and foothills from Yakutat Bay to west of Kayak Island. Cenozoic sedimentary rocks (fig. 30) are also found beneath Middleton Island and in State waters surrounding it. The area within the province underlain by Cenozoic rocks measures about $7,240 \mathrm{mi}^{2}$.

Paleocene through Oligocene rocks within the coastal sedimentary belt are known to include some sections with favorable hydrocarbon characteristics, including thermally mature source rocks and reservoirs. Miocene and younger rocks may have some reservoir potential but include no known good source rocks. The structural complexity and the young development age of potential traps within the province have apparently prevented commercial hydrocarbon accumulations in the anticlines that have so far been tested. Thus, major reasons for the lack of oil or gas discoveries include the young age and complexity of structures, poor source-rock potential of the thick Miocene and younger overlying sequence, and a lack of reservoir rocks in the lower Tertiary sections tested by drilling. Certain attributes indicative of hydrocarbon potential in the province include extensive oil and gas seeps and numerous anticlinal structures. The most positive attribute was the discovery of a small field at Katalla that produced minor amounts of oil between 1902 and 1933 before being abandoned. Two plays were identified and individually assessed in the province: Tertiary Gas and Tertiary Oil. 
REGION 1, ALASKA; REGION 2, PACIFIC COAST

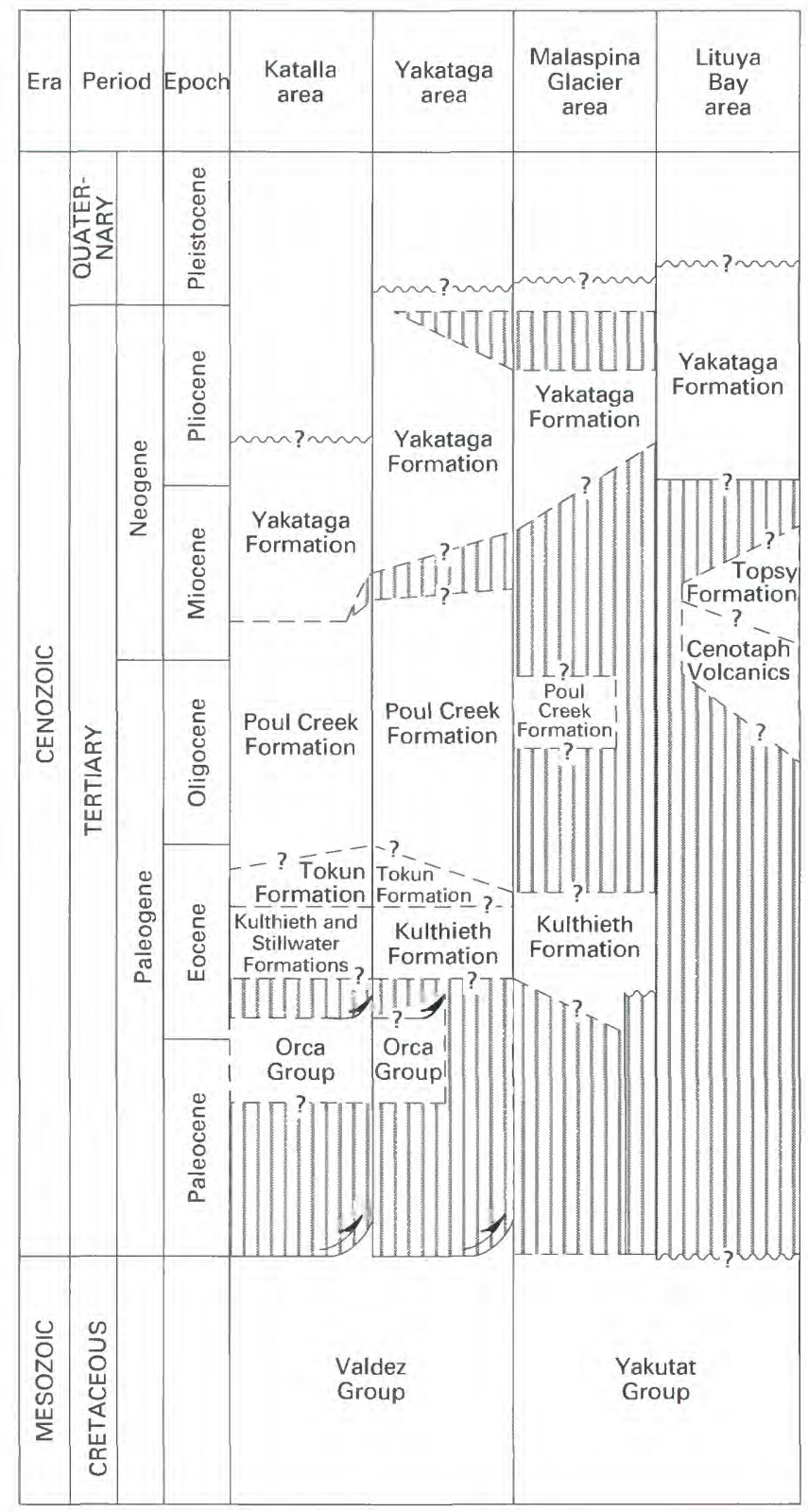

EXPLANATION

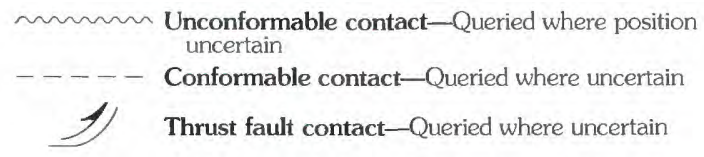

Figure 30. Generalized stratigraphic column, Gulf of Alaska province (069). Vertical line pattern, hiatus; queried where extent uncertain. 


\section{TERTIARY GAS PLAY AND TERTIARY OIL PLAY (020) (030)}

The two plays are treated for this discussion as a single play in that they have a common play area; however, for purposes of resource estimation, they were assessed as individual plays, differentiated only by the commodities assessed. The play is characterized by Paleocene to Miocene age clastic reservoirs and shale source rocks in complexly faulted anticlinal traps. The play area trends west to southeast, covers about $20,000 \mathrm{mi}^{2}$, and is bounded by the Ragged Mountain, Chugach-St. Elias, and Fairweather fault systems and the State-Federal 3-mile offshore boundary (fig. 31). Rocks beneath Kayak and Middleton Islands are also included in the play.

Reservoirs are primarily barrier beach and deltaic sandstones in the Eocene Stillwater, Kulthieth, and Tokun Formations (fig. 30). Maximum thickness of these formations is about $10,000,9,000$, and $3,000 \mathrm{ft}$, respectively. Fractured Oligocene and Miocene shale units in the Poul Creek Formation, as much as 6,000 ft thick, also act as reservoirs. Also included in the total rock sequence is the Miocene and younger Yakataga Formation, which consists mainly of marine diamictite and reaches a maximum thickness of 20,000 ft. Reservoir sandstones in Paleogene formations are mostly poorly sorted and mineralogically unstable; diagenetic alteration of grain matrix has produced widespread zeolite cement and pseudomatrix. The sandstones have been strongly deformed during burial, causing extensive grain alteration and interpenetration. As a result, quality of reservoirs is generally poor.

Potential source rocks are shale units in the Stillwater, Kulthieth, Tokun, and Poul Creek Formations. Total organic-carbon content in selected, organic-rich samples ranges from 0.42 to 1.87 percent, but this includes substantial reworked kerogen. The organic matter is predominantly herbaceous, with subordinate amounts of woody and amorphous kerogen, and can generate both oil and gas. In outcrops and well samples, the rocks are thermally immature to marginally mature. Organic carbon in the Yakataga Formation rarely exceeds 0.5 percent, and it is immature; these rocks have poor sourcerock characteristics. Hydrocarbon generation and migration from Paleogene rocks most likely occurred during the late Cenozoic, concurrent with (1) thermal heating and expulsion of generated hydrocarbons during burial by the thick Yakataga Formation, and (2) anticlinal deformation. Migration of hydrocarbons in seeps appears to be largely fault controlled. The present heat-flow regime is relatively cool, with the geothermal gradient estimated at $1.1-1.65^{\circ} \mathrm{F} / 100 \mathrm{ft}$ based on temperatures measured in wells.

The play area is underlain by a late Cenozoic fold-and-thrust belt in which faulted anticlines provide potential hydrocarbon traps. Paleogene or early Neogene anticlines may have been present, and could have been overprinted by later Cenozoic deformation. Traps could also be formed by structural or stratigraphic closure against faults. However, structural complexity onshore is so extreme as to make trap potential unfavorable on many if not most structures. Shale units in both the Poul Creek and Yakataga Formations could provide seals for underlying reservoir rocks.

The play is moderately explored. The small Katalla field produced the only commercial oil from the Gulf of Alaska, about 154,000 barrels between 1902 and 1933, from shallow fracture zones in shale of the Poul Creek Formation. Elsewhere, 25 dry holes and coreholes have been drilled, mainly on major anticlines, and one additional well was drilled near Middleton Island. In the adjacent offshore, 11 dry holes were drilled between 1976 and 1983 on the most promising structures. Thus, the most favorable accessible structures throughout the Gulf of Alaska have apparently been tested. The failure to find commercial hydrocarbons apparently results from complicated structure, poor reservoir quality, and immature or poor source rocks. Future potential for gas and oil is estimated to be moderate, and exploration may be largely for hard-to-define traps lying below the surface structures and thrust faults that cut the play area. 


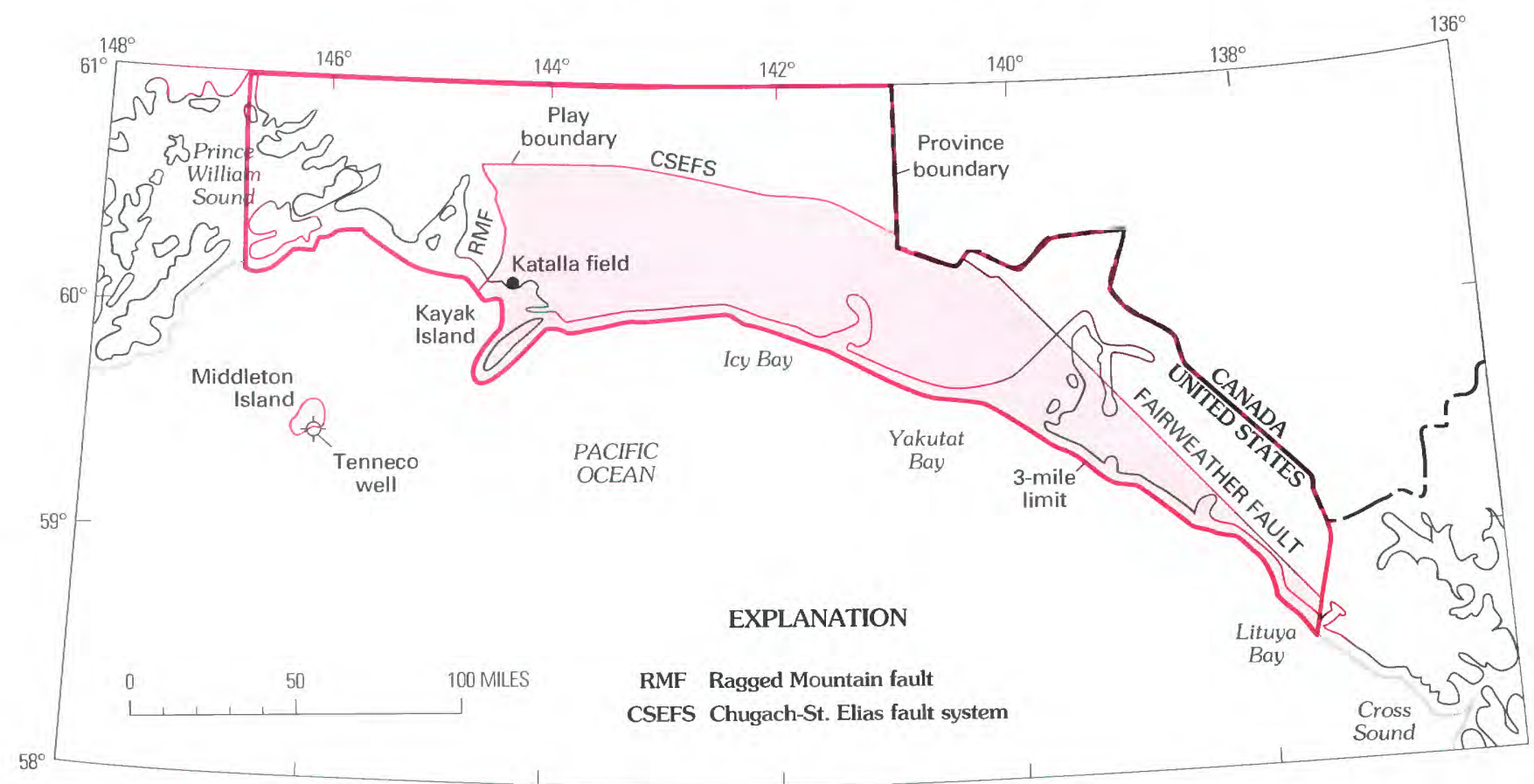

Figure 31. Map of Tertiary Gas play and Tertiary Oil play $(069-020,030)$.

OIL AND GAS PLAY DATA

PLAY TERTIARY GAS

PROVINCE GULF OF ALASKA

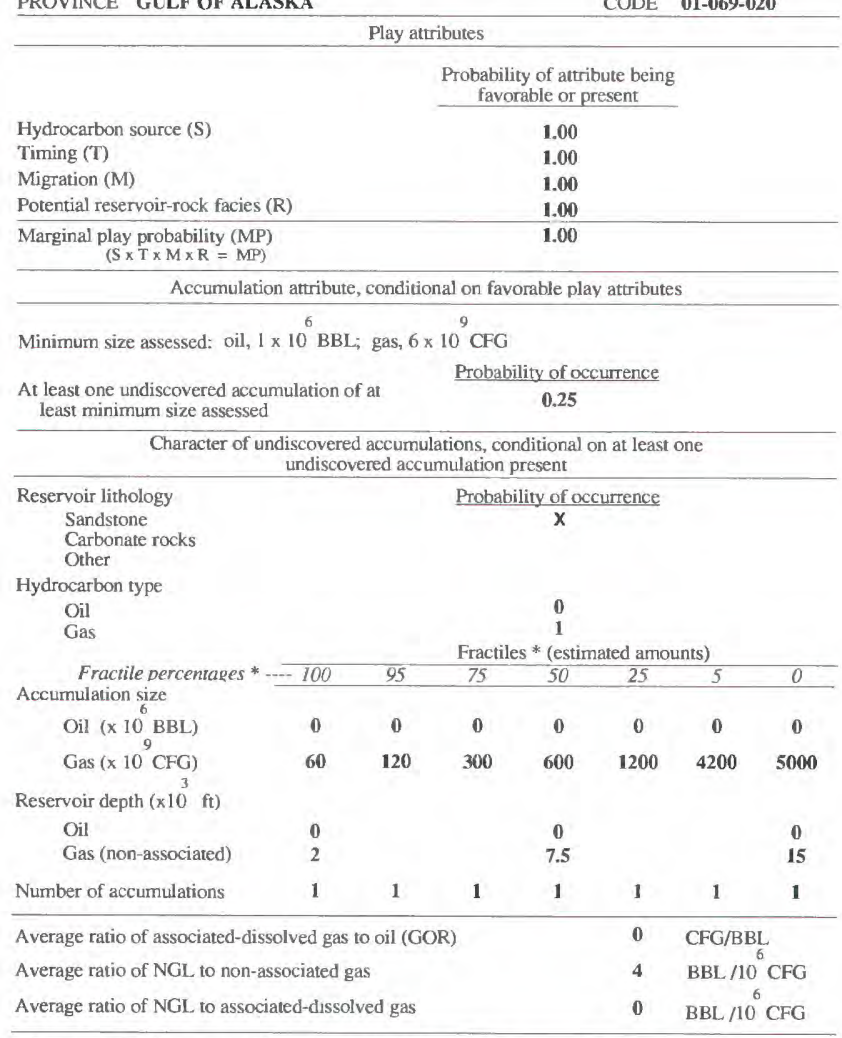
- For example, fractile percentage 95 represents a 19 in 20 chance of the occurrence of at least
OIL AND GAS PLAY DATA

PLAY TERTIARY OIL

PROVINCE GULF OF ALASKA CODE 01-069-030

\begin{tabular}{|c|c|}
\hline \multicolumn{2}{|c|}{ Play attributes } \\
\hline & $\begin{array}{c}\text { Probability of attribute being } \\
\text { favorable or present }\end{array}$ \\
\hline Hydrocarbon source (S) & 1.00 \\
\hline Timing ( $\mathrm{T}$ ) & 1.00 \\
\hline Migration (M) & 1.00 \\
\hline Potential reservoir-rock facies (R) & 1.00 \\
\hline $\begin{array}{l}\text { Marginal play probability (MP) } \\
\text { ( } \times T \times M \times R=M P \text { ) }\end{array}$ & 1.00 \\
\hline
\end{tabular}

Minimum size assessed: oil, $1 \times 10^{6} \mathrm{BBL}$; gas. $6 \times 10^{9} \mathrm{CFG}$

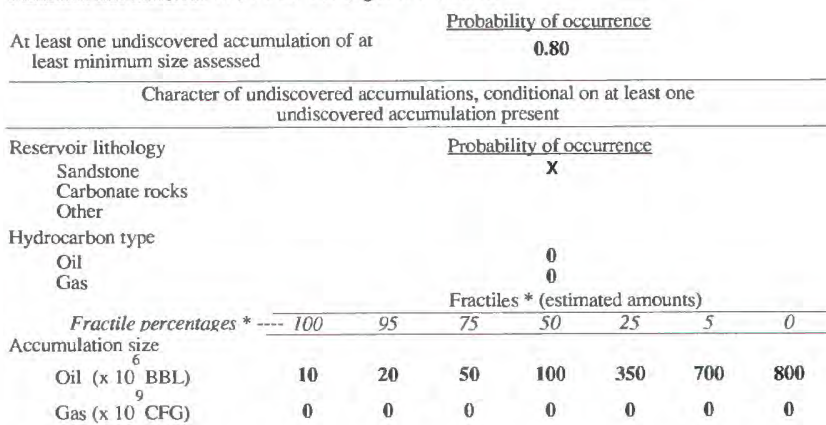

\begin{tabular}{|c|c|c|c|c|c|c|c|}
\hline \multicolumn{8}{|l|}{ Reservoir depth $(\mathrm{x} 10 \mathrm{ft})$} \\
\hline Oil & 2 & & & 7.5 & & & 0.5 \\
\hline \multirow{2}{*}{ Number of accumulations } & 0 & & & $\mathbf{0}$ & & & $\mathbf{0}$ \\
\hline & 1 & 1 & 1 & 1 & 1 & 1 & 1 \\
\hline \multicolumn{5}{|c|}{ Average ratio of associated-dissolved gas to oil (GOR) } & 1000 & \multirow{2}{*}{\multicolumn{2}{|c|}{$\begin{array}{l}\text { CFG/BBL } \\
\text { BBL } / 10_{6} \text { CFG }\end{array}$}} \\
\hline \multicolumn{5}{|c|}{ Average ratio of NGL to non-associated gas } & 0 & & \\
\hline \multicolumn{5}{|c|}{ Average ratio of NGL to associated-dissolved gas } & 0 & \multicolumn{2}{|c|}{$\mathrm{BBL} / 10^{6} \mathrm{CFG}$} \\
\hline
\end{tabular}
* For example, fractile percentage 95 represents a 19 in 20 chance of the occurrence of at least 


\title{
KODIAK ISLAND PROVINCE (070)
}

\author{
By Michael A. Fisher
}

The Kodiak Island province is located in the western Gulf of Alaska and covers an area of about $7,800 \mathrm{mi}^{2}$ (fig. 32). Most rocks exposed on the Kodiak islands are so strongly deformed and highly indurated that neither traps nor reservoir rocks for hydrocarbons are expected. The strong deformation is the result of a protracted Mesozoic and Cenozoic history of convergent-margin tectonics. Although the bleak assessment does not pertain to Miocene and younger rocks, their limited onshore exposure means that they could contain significant hydrocarbons only in offshore areas. Furthermore, within $3 \mathrm{mi}$ of the shoreline (State-Federal boundary) seismic reflection data indicate that these rocks are thin and unlikely to contain hydrocarbons in economic quantities.

Values of vitrinite reflectance and thermal alteration index from samples obtained on the islands suggest that Eocene and Oligocene rocks, as well as Neogene rocks, are either immature or just barely mature for generating hydrocarbons. These rocks generally have less than 0.4 percent organic carbon, which is contained in woody and herbaceous kerogen. Paleocene and older rocks are thermally overmature for hydrocarbon generation. Scattered measurements of porosity and permeability indicate that rocks of nearly all ages would make poor reservoirs for hydrocarbons.

The Kodiak group of islands are underlain by the Peninsular, Chugach, and Prince William tectonostratigraphic terranes. Along the northwest coasts of the islands, the Peninsular and Chugach terranes lie sutured along the Border Ranges fault. The Peninsular terrane includes Triassic sandstone and greenstone as well as Early Jurassic plutonic and metamorphic rocks. The Chugach terrane includes Cretaceous melange and strongly deformed, uppermost Cretaceous turbidite sequences. The Prince William terrane crops out along the southeast coasts of the islands and is represented by Paleogene, strongly deformed turbidite sequences, melange and locally exposed basalt. Post-Eocene rocks form an overlap sequence that crops out in scattered patches, and the sequence unconformably overlies the Eocene and older turbidite sequences. The overlap sequence includes Oligocene nonmarine and Miocene marine sandstone as well as upper Miocene sandstone and conglomerate.

Six COST (Continental Offshore Stratigraphic Test) wells were drilled offshore, but these wells led to no sustained offshore exploration activity, and the onshore area of this province has rightly been ignored. No plays were identified in the province, and no assessment of resources was made. 
REGION 1, ALASKA; REGION 2, PACIFIC COAST

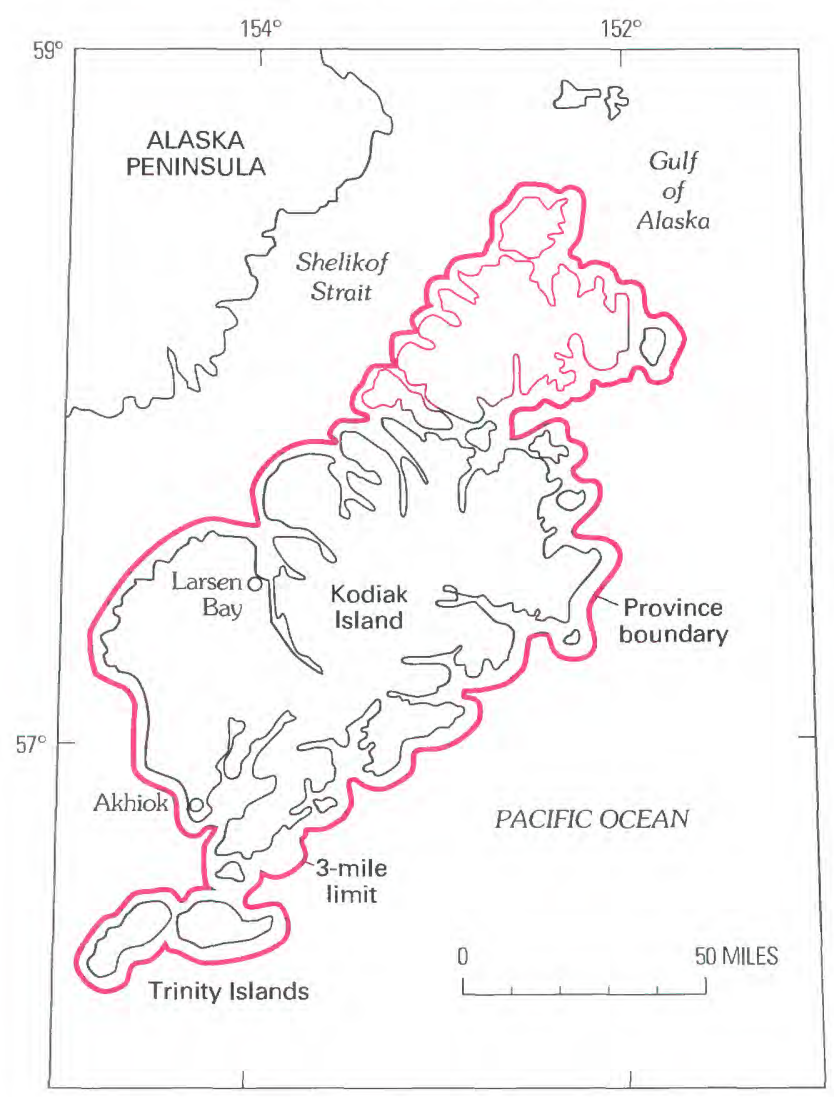

Figure 32. Map of Kodiak Island province (070). 


\title{
SOUTHEASTERN ALASKA PROVINCE (071)
}

\author{
By Terry R. Bruns
}

The Southeastern Alaska province, about $400 \mathrm{mi}$ long by $125-150 \mathrm{mi}$ wide, encompasses all islands and lands of southeastern Alaska from Dixon Entrance to northwest of Cross Sound and seaward of the United States/Canada border (fig. 33), and includes State waters that extend $3 \mathrm{mi}$ seaward of the islands. The province is covered dominantly by heavily forested, mountainous terrain, and deep channels separate the mainland from the offshore islands. The entire onshore province and contiguous State waters are underlain by a diverse assemblage of moderately to highly metamorphosed, intruded, and deformed Paleozoic and Mesozoic rocks comprising parts of five faultbounded tectonostratigraphic terranes. Cenozoic rocks consist of numerous plutons and local, thin nonmarine or deltaic rocks.

No hydrocarbon exploration has occurred in the province, and no evidence of hydrocarbons in the form of seeps is known. None of the criteria required for petroleum generation and accumulation are known to be present onshore, or in the immediately adjacent State offshore in southeastern Alaska. Except for the thin nonmarine and deltaic Cenozoic deposits, all the rocks underlying the islands or beneath the State 3-mile limit surrounding the islands are intruded, indurated, metamorphosed, and (or) deformed to a degree that makes these rocks effective economic basement for hydrocarbons. No potential source or reservoir rocks are known. Cenozoic rocks present in adjacent offshore basins around the province do not crop out onshore, and the petroleum potential of these offshore Cenozoic basins is also considered to be poor. Thus, little potential exists for migration of hydrocarbons from these Cenozoic basins updip into the onshore area, even if reservoir rocks and traps exist onshore. No hydrocarbon plays were identified, and no assessment of resources was made.

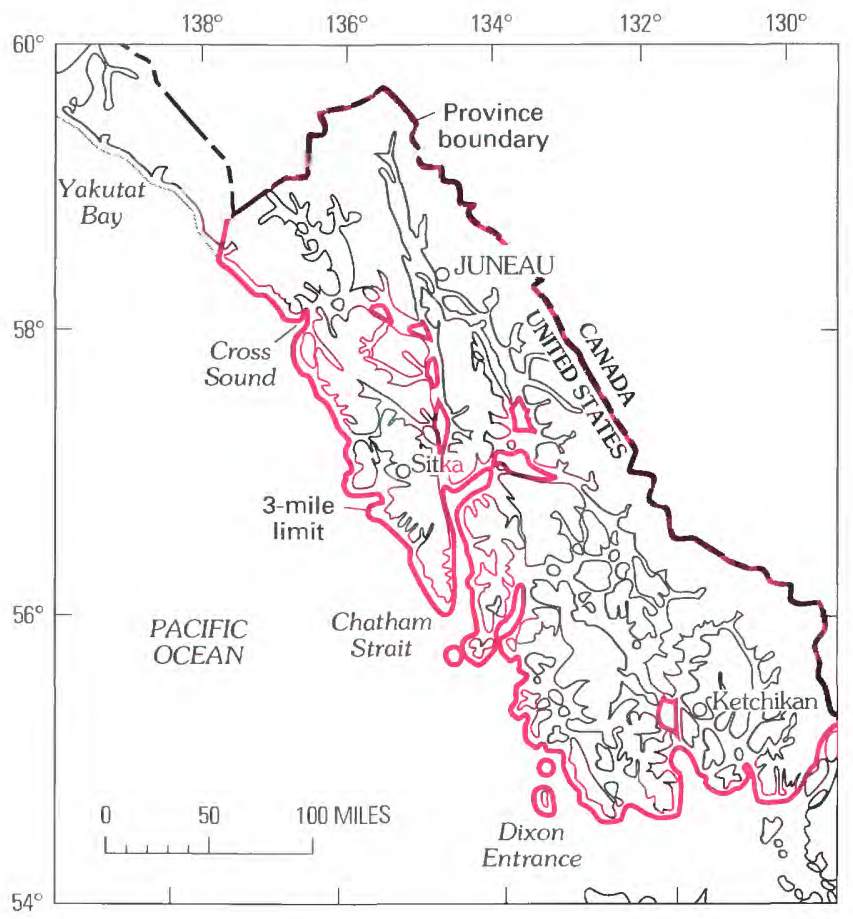

Figure 33. Map of Southeastern Alaska province (071). 


\section{SELECTED REFERENCES}

\section{Region 1, Alaska}

Arctic Coastal Plain (058), Northern Foothills (059), Southern Foothills-Brooks Range (060) provinces

Bird, K.J., 1991, Geology, play descriptions, and petroleum resources of the Alaskan North Slope (Petroleum Provinces 58-60): U.S. Geological Survey Open-File Report 88-450-Y, 52 p.

Kandik (061), Alaska Interior (062), Interior Lowlands (063), Bristol Basin (064) provinces

Magoon, L.B., and Kirschner, C.E., 1990, Alaska onshore National Assessment Program-Geology and petroleum resource potential of six onshore Alaska provinces: U.S. Geological Survey Open-File Report 88-450-T, 47 p.

Hope Basin province (065)

Fisher, M.A., 1988, Petroleum geology of the onshore part of Hope and Kotzebue basins, Alaska-A report for the Federal Lands Assessment program (FLAP): U.S. Geological Survey Open-File Report 88-383, 5 p.

\section{Copper River province (066)}

Magoon, L.B., and Kirschner, C.E., 1990, Alaska onshore National Assessment Program-Geology and petroleum resource potential of six onshore Alaska provinces: U.S. Geological Survey Open-File Report 88-450-T, 47 p.

\section{Cook Inlet province (067)}

Magoon, L.B., and Kirschner, C.E., 1990, Alaska onshore National Assessment Program-Geology and petroleum resource potential of six onshore Alaska provinces: U.S. Geological Survey Open-File Report 88-450-T, 47 p.

Alaska Peninsula province (068)

McLean, Hugh, 1988, Federal Lands Assessment Program-Alaska Peninsula, Alaska (Province 68): U.S. Geological Survey Open-File Report 87-450-H, 7 p.

Gulf of Alaska province (069)

Bruns, T.R.,1988, Petroleum geology and hydrocarbon plays of the Gulf of Alaska Onshore Province-A report for the National Hydrocarbon Assessment program: U.S. Geological Survey Open-File Report 88-450-J, 61 p.

Kodiak province (070)

Fisher, M.A., 1988, Petroleum geology of rocks exposed on Kodiak Island, Alaska-A report for the Federal Lands Assessment program (FLAP): U.S. Geological Survey Open-File Report 88-385, $6 \mathrm{p}$.

Southeastern Alaska province (071)

Bruns, T.R., 1988, Petroleum potential of southeastern Alaska-A report for the National Hydrocarbon Assessment Program: U.S. Geological Survey Open-File Report 88-450-I, 7 p. 


\section{PETROLEUM EXPLORATION PLAYS AND RESOURCE ESTIMATES, 1989, UNITED STATES}

Table 1. Region 1, Alaska-Estimates of undiscovered recoverable conventional oil, gas, and natural gas liquids (NGL) in onshore provinces and adjacent State waters, by play.

(Province and region totals are given except for the North Slope provinces 058, 059, and 060, which are totaled as a unit, because of play apportionment among them. Mean value totals may not be equal to the sums of the component means because numbers have been independently rounded. Fractile values $\left(\mathrm{F}_{95}\right.$, $\left.\mathrm{F}_{5}\right)$ are not additive and represent estimates with a 19 in 20 chance and a 1 in 20 chance, respectively, of at least these tabulated estimates. Gas includes both nonassociated and associateddissolved gas. Negl., negligible quantity; -, no estimate]

\begin{tabular}{|c|c|c|c|c|c|c|c|c|c|c|}
\hline & & \multicolumn{3}{|c|}{$\begin{array}{c}\text { Crude oil } \\
\text { (Millions of barrels) }\end{array}$} & \multicolumn{3}{|c|}{$\begin{array}{c}\text { Total gas } \\
\text { (Billions of cubic feet) }\end{array}$} & \multicolumn{3}{|c|}{$\begin{array}{c}\text { NGL } \\
\text { (Millions of barrels) }\end{array}$} \\
\hline & & $F_{95}$ & $F_{5}$ & Mean & $\overline{F_{95}}$ & $F_{5}$ & $\overline{\text { Mean }}$ & $\overline{\mathrm{F}_{95}}$ & $F_{5}$ & Mean \\
\hline \multicolumn{11}{|c|}{058 Arctic Coastal Plain } \\
\hline 020 & Topset & 533.6 & $6,715.9$ & $2,542.1$ & 43.2 & $2,274.2$ & 647.6 & 0.0 & 0.0 & 0.0 \\
\hline 030 & Western Turbidite & 18.0 & 231.9 & 90.3 & 642.8 & $3,761.7$ & $1,796.2$ & 12.9 & 75.2 & 35.9 \\
\hline 040 & Eastern Turbidite & 386.0 & $2,750.7$ & $1,230.3$ & $1,303.6$ & $9,656.8$ & $4,270.1$ & 52.1 & 386.3 & 170.8 \\
\hline 050 & Barrow Arch & 575.4 & $4,599.0$ & $1,984.1$ & 892.7 & $10,370.0$ & $4,016.9$ & 35.7 & 414.8 & 160.7 \\
\hline 060 & Ellesmerian Clastics ${ }^{a}$ & 9.8 & 251.7 & 83.0 & $1,229.1$ & $14,389.0$ & $5,562.0$ & 18.4 & 215.8 & 83.4 \\
\hline 070 & Lisburne & 0.0 & 0.0 & 0.0 & 599.5 & $10,726.0$ & $3,724.1$ & 9.0 & 160.9 & 55.9 \\
\hline 080 & Lisburne Unconformity & 0.0 & 138.0 & 30.1 & 0.0 & $5,685.8$ & $1,585.2$ & 0.0 & 142.1 & 39.6 \\
\hline 090 & Endicott & 0.0 & 0.0 & 0.0 & 0.0 & 614.5 & 216.6 & 0.0 & 9.2 & 3.2 \\
\hline 320 & Oil <1 MMB & 21.5 & 69.9 & 41.4 & 10.8 & 35.0 & 20.7 & 0.2 & 0.7 & 0.4 \\
\hline 330 & Gas $<6 \mathrm{BCF}$ & 0.0 & 0.0 & 0.0 & 150.4 & 445.9 & 273.5 & 3.0 & 8.9 & 5.5 \\
\hline \multicolumn{11}{|c|}{059 Northern Foothills } \\
\hline 020 & Fold Belt West ${ }^{b}$ & 209.0 & $2,038.4$ & 830.0 & $3,346.9$ & $18,742.0$ & $9,083.7$ & 50.2 & 281.1 & 136.3 \\
\hline 030 & Fold Belt East ${ }^{c}$ & 444.2 & $2,995.0$ & $1,363.6$ & 598.0 & $5,081.7$ & $2,153.8$ & 17.9 & 152.5 & 64.6 \\
\hline 320 & Oil < $\mathrm{MMB}^{\mathrm{d}}$ & 21.4 & 86.1 & 47.0 & 21.4 & 86.1 & 47.0 & 0.4 & 1.7 & 0.9 \\
\hline 330 & Gas $<6 \mathrm{BCF}^{\mathrm{d}}$ & 0.0 & 0.0 & 0.0 & 94.0 & 375.9 & 205.4 & 1.9 & 7.5 & 4.1 \\
\hline \multicolumn{11}{|c|}{060 Southern Foothills-Brooks Range } \\
\hline 020 & Thrust Belt West & 0.0 & $1,052.9$ & 240.7 & 0.0 & $10,672.0$ & $2,773.8$ & 0.0 & 106.7 & 27.7 \\
\hline 030 & Thrust Belt East $^{\mathrm{e}}$ & 593.4 & $11,875.0$ & $4,021.3$ & $2,727.9$ & $50,767.0$ & $17,466.1$ & 40.9 & 761.5 & 262.0 \\
\hline 320 & Oil $<1 \mathrm{MMB}^{\mathrm{d}}$ & 35.2 & 159.2 & 83.1 & 35.2 & 159.2 & 83.1 & 0.5 & 2.4 & 1.2 \\
\hline 330 & Gas $<6 \mathrm{BCF}^{\mathrm{d}}$ & 0.0 & 0.0 & 0.0 & 74.2 & 305.8 & 165.3 & 1.1 & 4.6 & 2.5 \\
\hline $\begin{array}{r}* \text { Total for } I \\
058,059\end{array}$ & $\begin{array}{l}60 \\
60 \text { Slope provinces }\end{array}$ & 2,502 & 33,838 & 12,587 & 10,545 & 146,400 & 54,091 & 224 & 2,769 & 1,055 \\
\hline \multicolumn{11}{|l|}{061 Kandik } \\
\hline 040 & Cordilleran Thrust & 0.0 & 486.8 & 109.5 & 0.0 & 486.8 & 109.5 & 0.0 & 0.0 & 0.0 \\
\hline 320 & Oil <1 MMB & 0.0 & 2.8 & 0.4 & 0.0 & 2.8 & 0.4 & 0.0 & 0.0 & 0.0 \\
\hline & Province total & 0.0 & 488.9 & 109.9 & 0.0 & 488.9 & 109.9 & 0.0 & 0.0 & 0.0 \\
\hline \multicolumn{11}{|c|}{062 Alaska Interior } \\
\hline 020 & Tertiary Basins & 0.0 & 0.0 & 0.0 & 408.7 & $2,600.3$ & $1,207.5$ & Negl. & 0.2 & 0.1 \\
\hline 330 & Gas $<6 \mathrm{BCF}$ & 0.0 & 0.0 & 0.0 & 42.7 & 248.9 & 119.0 & 0.0 & 0.0 & 0.0 \\
\hline & Province total & 0.0 & 0.0 & 0.0 & 451.3 & $2,849.3$ & $1,326.5$ & Negl. & 0.2 & 0.1 \\
\hline
\end{tabular}

063 Interior Lowlands (Incl. in 062)

064 Bristol Basin

$\begin{array}{ll}020 & \text { Tertiary } \\ 330 & \text { Gas <6 BCF } \\ & \text { Province total }\end{array}$

0.0

75.5

518.1

234.8

0.0

0.0

0.0

0.0

0.0

0.0

113.9

665.0

317.8

065 Hope Basin

066 Copper River Basin (Incl. in 062)

067 Cook Inlet

$\begin{array}{ll}020 & \text { Beluga-Sterling } \\ 030 & \text { Hemlock Conglomerate } \\ 320 & \text { Oil <1 MMB } \\ 330 & \text { Gas <6 BCF }\end{array}$

Province total
0.0

76.9

15.4

0.0

91.2
0.0

579.8

60.6

0.0

641.2
0.0
254.9

223.7

57.7

11.5

82.9

350.6 


\section{REGION 1, ALASKA; REGION 2, PACIFIC COAST}

Table 1. Region 1, Alaska-Estimates of undiscovered recoverable conventional oil, gas, and natural gas liquids (NGL) in onshore provinces and adjacent State waters, by play-Continued.

\begin{tabular}{|c|c|c|c|c|c|c|c|c|c|c|}
\hline & & \multicolumn{3}{|c|}{$\begin{array}{c}\text { Crude oil } \\
\text { (Millions of barrels) }\end{array}$} & \multicolumn{3}{|c|}{$\begin{array}{c}\text { Total gas } \\
\text { (Billions of cubic feet) }\end{array}$} & \multicolumn{3}{|c|}{$\begin{array}{c}\text { NGL } \\
\text { (Millions of barrels) }\end{array}$} \\
\hline & & $F_{95}$ & $F_{5}$ & Mean & $F_{95}$ & $F_{5}$ & Mean & $F_{95}$ & $F_{5}$ & Mean \\
\hline 068 Alaska & 'eninsula & - & - & - & - & - & - & - & - & - \\
\hline \multicolumn{11}{|c|}{069 Gulf of Alaska } \\
\hline 020 & Tertiary Gas & 0.0 & 0.0 & 0.0 & 0.0 & $1,645.8$ & 288.5 & 0.0 & 6.6 & 1.2 \\
\hline 030 & Tertiary Oil & 0.0 & 571.5 & 180.2 & 0.0 & 571.5 & 180.2 & 0.0 & 0.0 & 0.0 \\
\hline 320 & Oil < $1 \mathrm{MMB}$ & 4.6 & 25.7 & 12.5 & 4.6 & 25.7 & 12.5 & 0.0 & 0.0 & 0.0 \\
\hline \multirow[t]{2}{*}{330} & Gas $<6 \mathrm{BCF}$ & 0.0 & 0.0 & 0.0 & 23.8 & 176.6 & 78.0 & 0.1 & 0.7 & 0.3 \\
\hline & Province total & 26.9 & 578.4 & 192.7 & 32.7 & $2,001.5$ & 559.2 & 0.1 & 5.5 & 1.5 \\
\hline 070 Kodiak & & - & - & - & - & - & - & - & - & - \\
\hline 071 Souther & tern Alaska & - & - & - & - & - & - & - & - & - \\
\hline & REGION TOTAL & 3,605 & 31,289 & 13,177 & 15,562 & 138,640 & 57,935 & 296 & 2,481 & 1,056 \\
\hline
\end{tabular}

a Play estimate shown has been apportioned to the Coastal Plain province ( 80 percent) and the Northern Foothills province (20 percent).

b Play estimate shown has been apportioned to the Northern Foothills province (98 percent) and the Southern Foothills-Brooks Range province (2 percent).

c Play estimate shown has been apportioned to the Coastal Plain province ( 73 percent), the Northern Foothills province (25 percent), and the Southern Foothills-Brooks Range province (2 percent).

d Estimates shown have been apportioned to the Coastal Plain, Northern Foothills, and Southern Foothills-Brooks Range provinces.

e Play estimate shown has been apportioned to the Coastal Plain province (66 percent), the Northern Foothills province ( 30 percent), and the Southern FoothillsBrooks Range province (4 percent).

"Estimates for North Slope provinces are not totalled individually because several plays are apportioned among the provinces, as indicated in the lettered footnotes. 


\title{
REGION 2, PACIFIC COAST
}

\section{GEOLOGIC FRAMEWORK}

\author{
By Richard B. Powers
}

Region 2, encompassing all of California, Oregon, and Washington, is subdivided into 11 provinces (numbered 072-081A) (fig. 34). The total number of individually assessed plays in these provinces is 21 . The San Joaquin Basin province alone contains one-third of the assessed plays in the region, and several provinces have no plays at all.

Because of the active tectonic history of Region 2, during which older basins were destroyed and new ones created, rocks prospective for petroleum are limited mainly to basins that formed during Cenozoic time.

Most of western Oregon and Washington is the site of a forearc basin composed of great thicknesses of sedimentary and volcanic rocks of Tertiary age. The area is stratigraphically complex but only moderately folded and faulted; only small occurrences of gas and scattered shows of oil have been reported to 1987. Most of eastern Oregon and Washington and part of northeastern California comprise a high plateau with a thick volcanic cover. Because of this cover, basins in the province are poorly defined and the distribution of prevolcanic rocks not well understood; however, thick sequences of lower Tertiary and Upper Cretaceous sedimentary rocks are known to be present locally beneath the volcanics and are considered to have potential for gas resources.

The Great Valley of California, composed of the San Joaquin and Sacramento basins, is a forearc basin that has a thick sequence of marine and nonmarine rocks which range in age from Late Jurassic to Holocene. The Great Valley is highly productive of gas in the north and of oil in the south. The area has a long history of exploration, but future potential appears rather limited. Undiscovered resources are thought to be in deeper parts of the basins, in subtle traps, in complex traps within producing trends, and in a few relatively unexplored areas.

The California coastal basins are located south and west of the Great Valley. They are small but typically contain very thick Neogene sedimentary rock fill. Several of these basins have been exceedingly rich in discovered petroleum, particularly the Los Angeles, Ventura, and Santa Maria basins. Principal producing zones are in Miocene and Pliocene reservoir rocks, primarily sandstone units and fractured siliceous rocks. Because of the extent of exploration, the potential for undiscovered resources in these provinces is considered modest; most of the undiscovered oil is believed to be in deep parts of the basins, in subtle traps, in complex traps in producing trends, and in other areas of the basins that have been incompletely explored. 


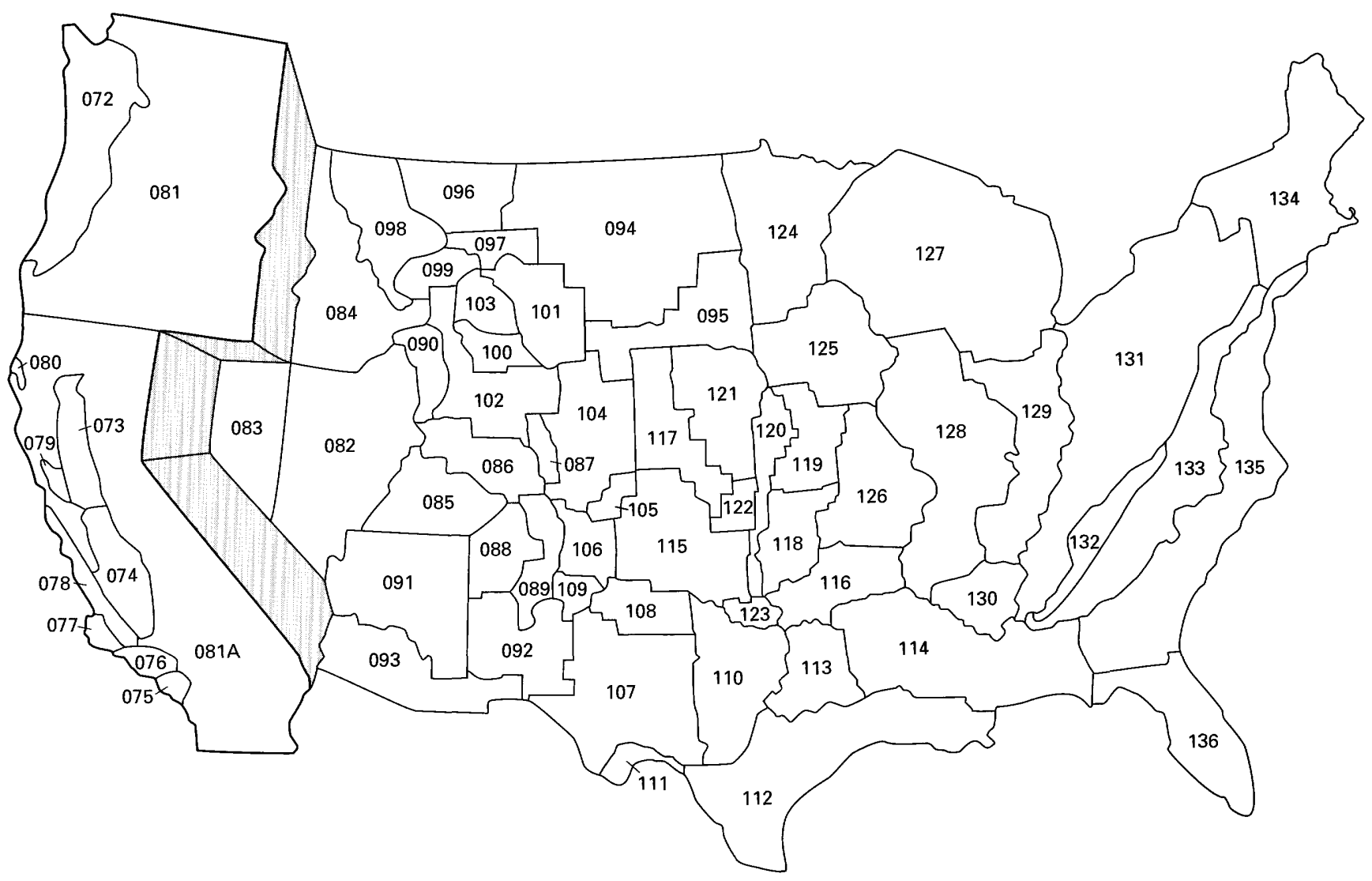

Figure 34. Index map of lower 48 States, showing provinces assessed in Region 2 (front-shifted block). Names of provinces are listed by number in the table of estimates (table 2, p. A137). 


\title{
WESTERN OREGON-WASHINGTON PROVINCE (072)
}

\author{
By Richard G. Stanley \\ INTRODUCTION
}

Province 072 includes western Oregon and Washington from the Cascade Range westward to the 3-mile limit offshore, and from the Straits of Juan de Fuca southward to the Klamath Mountains (location, fig. 34). The province is about $440 \mathrm{mi}$ long and 50-140 mi wide. Most of this area lies within a forearc basin that is floored by Paleocene and lower Eocene oceanic basaltic crust and contains as much as $25,000 \mathrm{ft}$ of Eocene and younger sedimentary and volcanic rocks (fig. 35).

More than 500 wells have been drilled in the province since 1900 . A wildcat well drilled near Ocean City, Wash., in 1957 produced about 12,000 barrels of $39^{\circ}$ API gravity paraffin-base oil; however, the well experienced rapid pressure decline and was abandoned in 1962. Not until 1979 was the first commercial production in the province established at the Mist gas field, northwest of Portland, Oreg. Only one play, the Tertiary Gas play, was individually assessed in this province. 
REGION 1, ALASKA; REGION 2, PACIFIC COAST

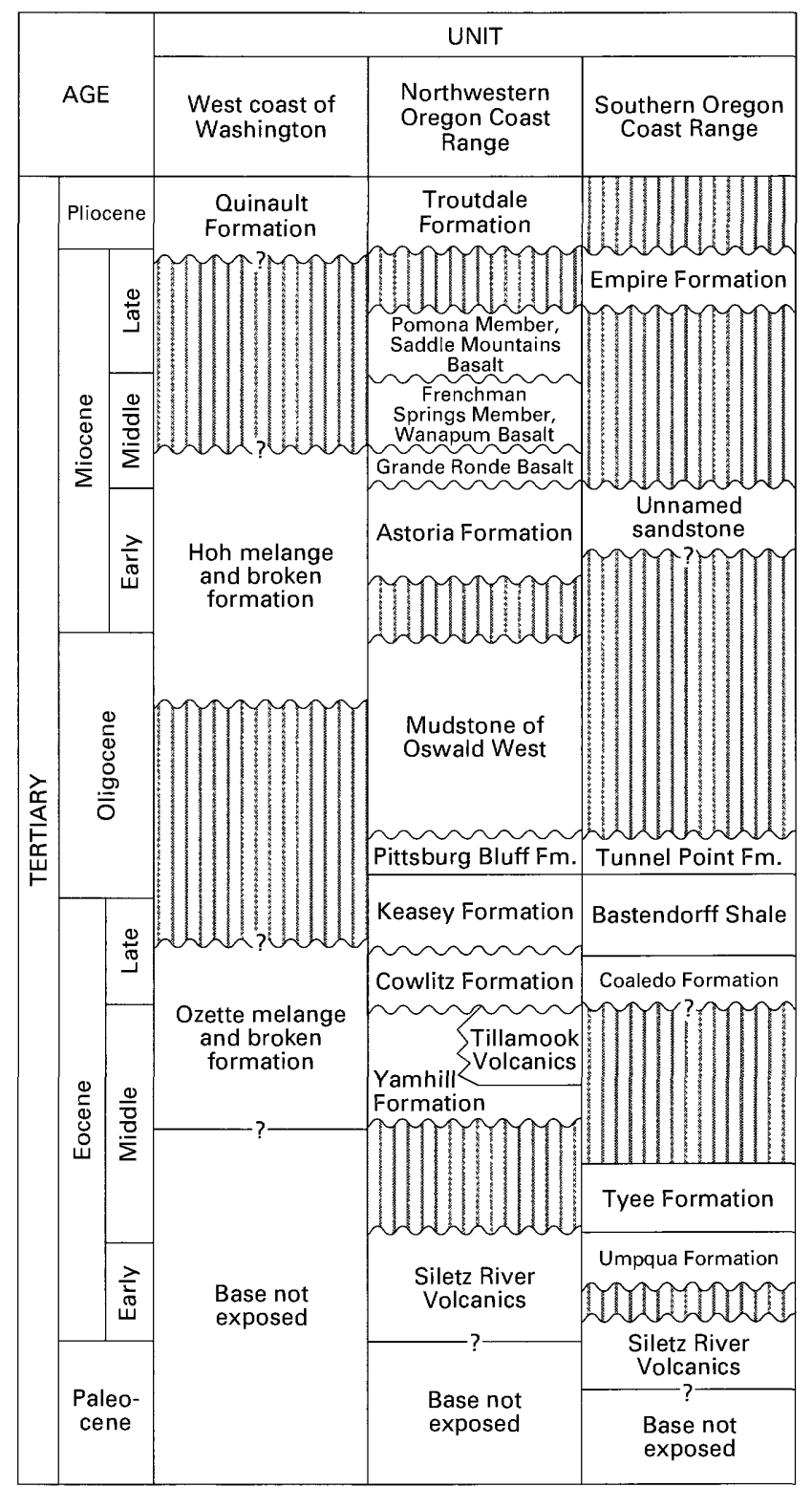

Figure 35. Generalized stratigraphic column, Western Oregon-Washington province (072). Vertical line pattern, hiatus. Wavy line, unconformable contact. Contacts queried where uncertain. 


\section{TERTIARY GAS PLAY (020)}

The Tertiary Gas play is characterized by gas accumulations in complexly faulted structural and stratigraphic traps in quartzofeldspathic sandstone reservoirs (fig. 35). The play is based on the assumption that the Mist gas field, the only field of commercial size in the province, is an analog for additional undiscovered gas accumulations of similar or larger size. The province and play boundaries are the same; the play includes nearly all Tertiary sedimentary strata in western Oregon and Washington. Certain parts of the province can be rejected outright as having no petroleum potential; these include surface exposures of Paleocene and Eocene volcanic rocks, and an area of low-grade Tertiary metamorphic rocks in the core of the Olympic Peninsula (fig. 36).

Known reservoirs are quartzofeldspathic sandstone units of shallow-marine origin in the Eocene Cowlitz Formation (fig. 35). The main productive sandstone reservoir in the Mist field is about $350-700 \mathrm{ft}$ thick; its porosities average about 25 percent and permeabilities average about 200 millidarcies. Outside the Mist field, reservoir-quality sandstone has been reported from several units, including the Eocene Cowlitz and Coaledo Formations, and the Miocene Astoria Formation (fig. 35). However, most sandstone units in western Oregon and Washington lack potential as hydrocarbon reservoirs because they are rich in unstable volcanic-lithic and feldspar grains that alter during diagenesis to clays, zeolites, and other minerals that clog pore spaces. During the 1950 's and 1960's, subcommercial production of oil was obtained from fractured siltstone reservoirs in the Oligocene and Miocene Hoh melange and broken formation (fig. 35) near Ocean City, Wash. (fig. 36). However, fractured reservoirs in the Hoh are small, have low permeability, and are considered unlikely to contain hydrocarbon accumulations as large as $6 \mathrm{BCFG}$ or $1 \mathrm{MMBO}$.

Potential source rocks in the play include marine and nonmarine shale, and nonmarine and deltaic coal. Organic geochemical studies show that most of the shale is organically lean and that both shale and coal are generally gas prone with predominantly Type III and Type IV kerogen of terrestrial derivation. Shows of dry gas are abundant, but shows of oil are few and generally small; therefore, the area is considered prospective mainly for nonassociated gas. Vitrinite reflectance studies show that most potential source rocks are thermally immature with respect to the hydrocarbon generation window. However, Lopatin diagrams suggest that petroleum generation may have occurred in depocenters where potential source rocks have been buried to depths of $10,000 \mathrm{ft}$ or more (fig. 36). Additional hydrocarbons may have been generated in areas of elevated heat flow, such as near igneous intrusions or along faults. Lopatin diagrams also indicate that petroleum generation and migration in the Mist field area may have begun during the Oligocene or earlier, and may be continuing today.

Gas at the Mist field is found in more than a dozen small pools at depths of 1,300-2,700 ft. Trapping conditions at Mist are complex; numerous fault traps and at least one stratigraphic trap lie on a large, northwest-trending anticline. Tuffaceous deepwater shale beds in the upper Cowlitz and Keasey Formations serve as seals (fig. 35). Traps elsewhere are expected to be comparable to Mist in size and geologic complexity.

The Mist field, discovered in 1979, produced about 38 BCFG through 1986. The play is considered an exploration frontier because drilling density is low, few deep tests have been attempted, and the geologic framework is only dimly understood. Future potential for gas is considered to be good. 


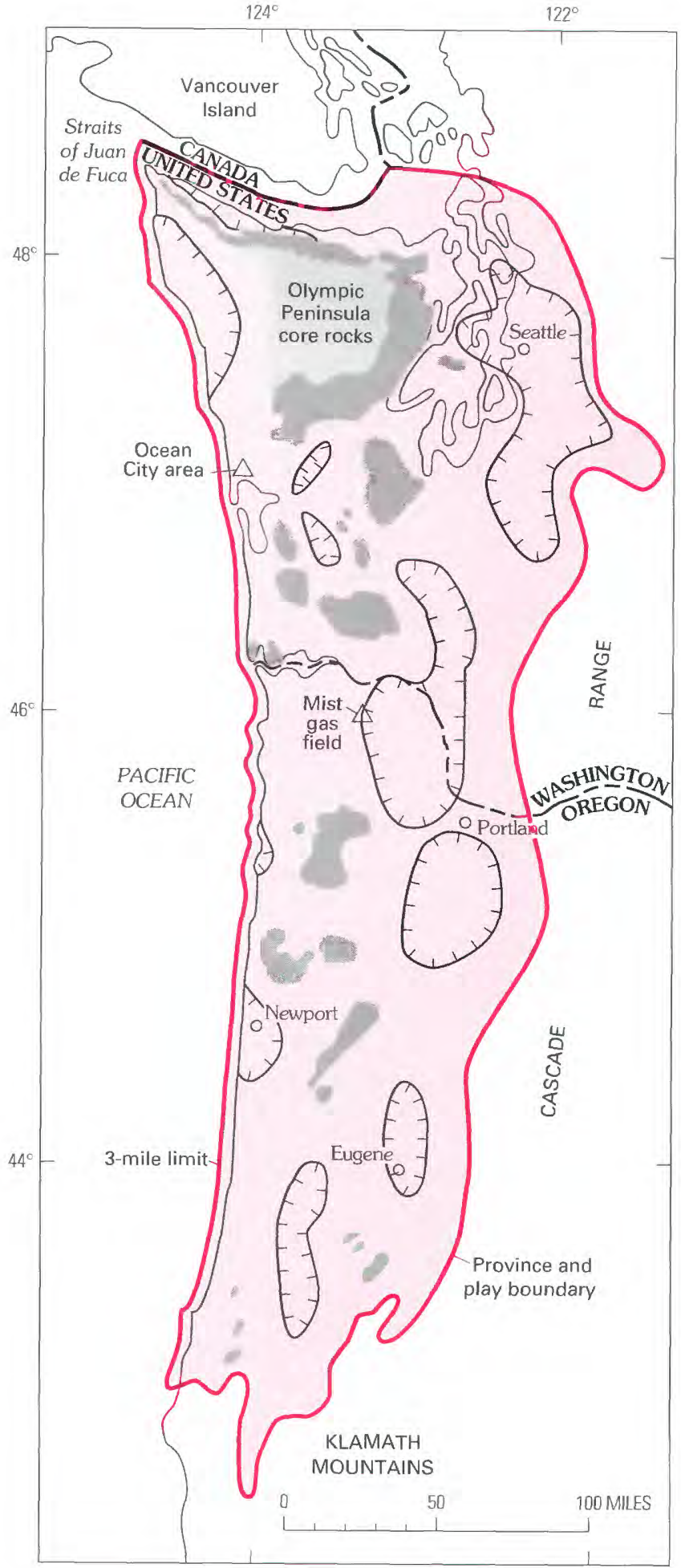

\section{EXPLANATION}

Paleocene and Eocene volcanic rocks

Depocenters-Tertiary sedimentary rocks more than $10,000 \mathrm{ft}$ thick
Figure 36. Map of Tertiary Gas play (072-020).

OIL AND GAS PLAY DATA

PLAY TERTIARY GAS

PROVINCE WESTERN OREGON-WASHINGTON

Play attributes

CODE 02-072-020

Probability of attribute being favorable or present

\begin{tabular}{ll} 
Hydrocarbon source (S) & 1.00 \\
Timing (T) & 1.00 \\
Migration (M) & 1.00 \\
Potential reservoir-rock facies (R) & 1.00 \\
\hline Marginal play probability (MP) & 1.00
\end{tabular}

Marginal play probability (MP)

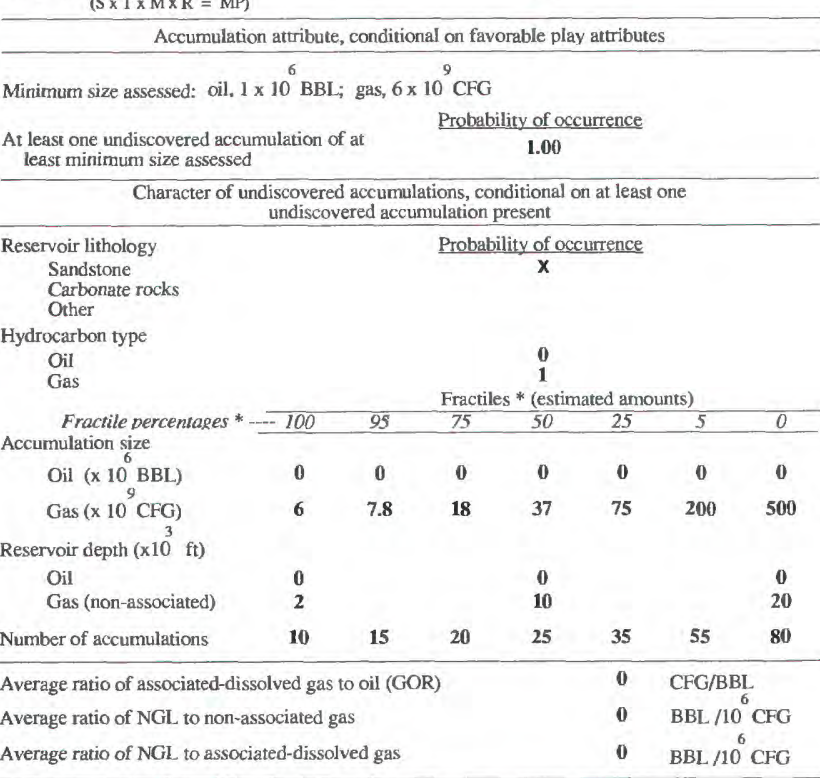

- For example, fractile percentage 95 represents a 19 in 20 chance of the occurrence of at least 


\title{
SACRAMENTO BASIN PROVINCE (073)
}

\author{
By Larry A. Beyer \\ INTRODUCTION
}

The Sacramento basin, which occupies the north half of the Great Valley of California, is an elongate, northwest-trending structural trough. The trough is filled with as much as $40,000 \mathrm{ft}$ of Jurassic to Holocene, marine and nonmarine clastic rocks deposited in a convergent-margin forearc basin between late Mesozoic and early Cenozoic time (fig. 37). The province, which is about $210 \mathrm{mi}$ long and $60 \mathrm{mi}$ wide, is bordered on the west by the Coast Ranges thrust, on the north by the Klamath Mountains, on the east by the Cascade Range and Sierra Nevada, and arbitrarily on the south by the Stanislaus-San Joaquin County line.

The Sacramento Basin province is primarily a gas-producing province with only one small oil field, Brentwood, located in its southern part. Major gas fields, with estimated recoverable gas as of January 1987, are Rio Vista (3.5 TCF), Grimes (638 BCF), Willows-Beehive Bend (379 BCF), Lindsay Slough (279 BCF), and Union Island (250 BCF). Cumulative production through 1986 from 144 discovered fields in the Sacramento basin is $7.95 \mathrm{TCFG}$ and $12.7 \mathrm{MMBO}$ and condensate. The first gas field, Sutter Buttes, was discovered in 1933. Intermittent discoveries of major fields culminated in the early 1960's and the last major discovery, Union Island, occurred in 1972. Smaller discoveries have continued to the present. Three plays were individually assessed in the province: Paleocene-Eocene, Starkey-Winters, and Guinda-Kione-Forbes. 
REGION 1, ALASKA; REGION 2, PACIFIC COAST

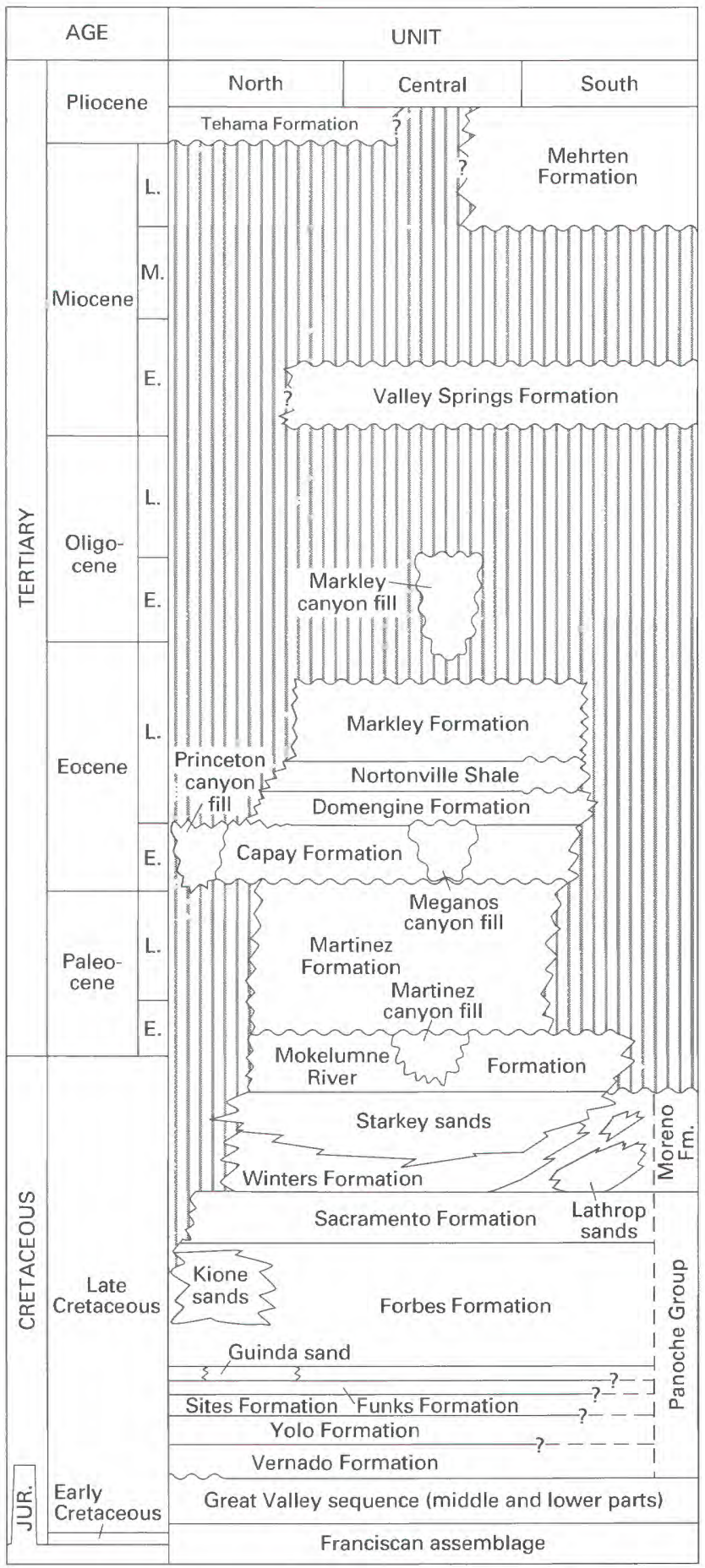

Figure 37. Generalized stratigraphic column, Sacramento Basin province (073). Vertical line pattern, hiatus. Wavy line, unconformable contact. Relations queried and (or) dashed where uncertain. 


\section{PALEOCENE-EOCENE PLAY (020)}

The play consists of gas accumulations in both structural and stratigraphic traps, in mostly shallow marine sandstones that were deposited during three transgressive-regressive depositional cycles, and in one younger partial cycle between early Paleocene and early Oligocene time. The play covers about $6,530 \mathrm{mi}^{2}$ (fig. 38). The lower stratigraphic boundary of the play is the widespread unconformity at the top of the Cretaceous section. The upper stratigraphic boundary is formed by post-Eocene unconformities overlain by Miocene and younger nonmarine sediments, except in the so-called Markley canyon fill where mostly Oligocene marine sediments overlie an early Oligocene unconformity.

Paleocene-Eocene sandstone reservoirs occur in the (1) Paleocene Martinez Formation (for example, the McCormick, First Massive, Anderson, and Wagenet sandstones of local usage in the Delta depocenter (figs. 37, 38)), (2) lower Eocene Capay Formation (Hamilton sand of local usage in the Delta depocenter), (3) middle Eocene Domengine Formation (lateral equivalent of Ione Formation), and (4) middle or upper Eocene Nortonville Shale and Markley Formation. Marine sandstone beds in the lower Eocene so-called Princeton canyon fill and Eocene Capay Formation, both in the northern part of the basin, are also included in this play, along with sandstone beds in the lower Eocene so-called Meganos canyon fill in the southern part of the basin (fig. 38). Discovered reservoirs occur at depths from 1,440 to $10,228 \mathrm{ft}$, and have thicknesses of 2-550 ft and porosities generally between 14 and 35 percent.

Gas probably is thermogenic in origin and was derived from Cretaceous deep basin shales and from shallower source rocks, some of which may be within the play sequence, that are presently in the oil window in the Delta depocenter (fig. 38). In the northern basin area, the origin of the gas also may be largely thermogenic, probably derived from deeply buried, gas-prone Cretaceous shale and mudstone along the western margin and, possibly, from the now-missing western part of the Cretaceous forearc basin. Gas generation probably began by the end of Cretaceous time, or earlier in the Delta depocenter. Most discovered and anticipated traps have a structural element, or involve updip erosional truncation, or are stratigraphic traps in impermeable submarine canyon fill.

Principal gas fields in the play (with year of discovery and cumulative production plus estimated reserves through 1986) are Rio Vista (1936, $3.3 \mathrm{TCF})$, Ryer Island (1967, 128 BCF), Dutch Slough (1963, 119 BCF), Maine Prairie (1945, 100 BCF), Suisun Bay (1944, 90 BCF), and Oakley South (1972, 75 BCF). Cumulative production plus estimated reserves of gas through 1986 in 48 fields is 4.39 TCF.

The play is mature, but because of the considerable complexity of traps and wide distribution of the many fields, future gas potential is considered fair to good. 


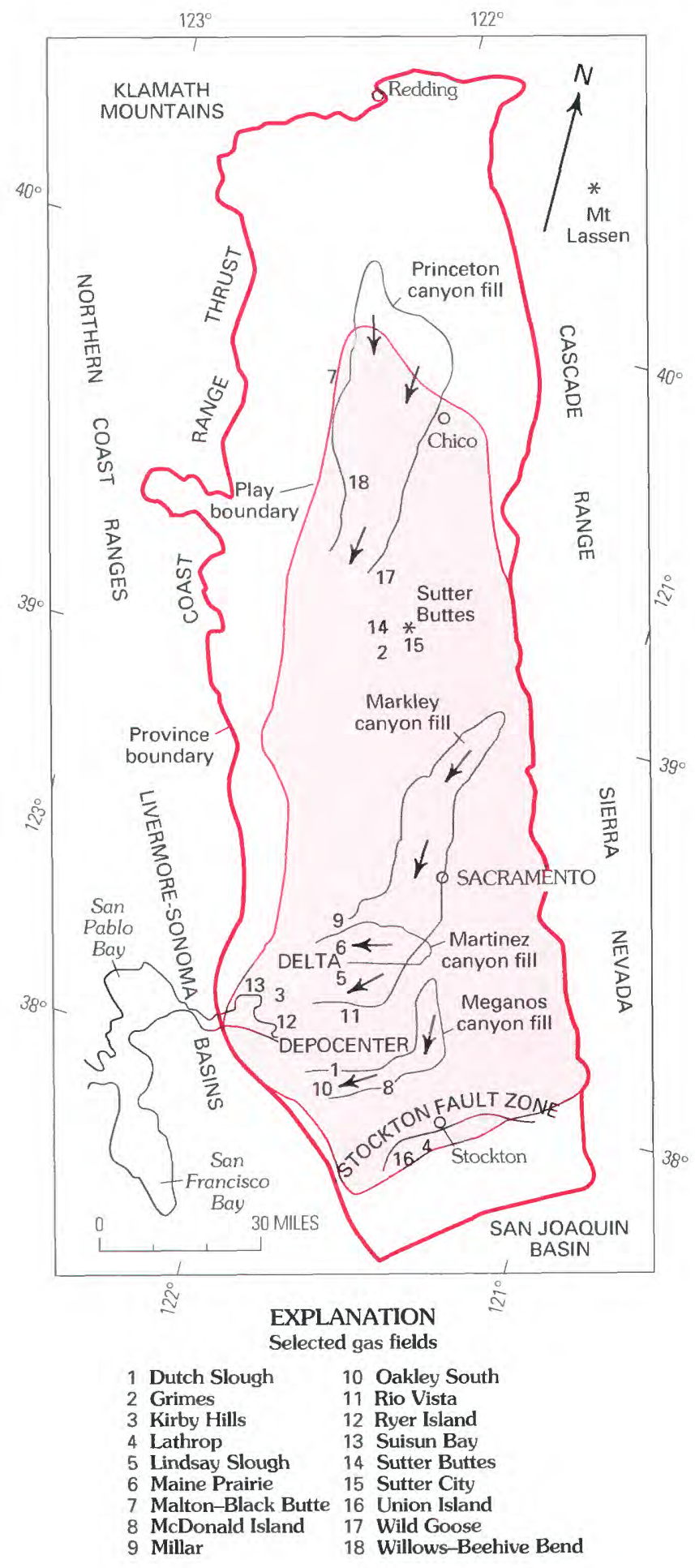

Figure 38. Map of Paleocene-Eocene play (073-020).

\section{PLAY \\ PALEOCENE-EOCENE \\ PROVINCE SACRAMENTO BASIN}

OIL AND GAS PLAY DAT

Play attributes

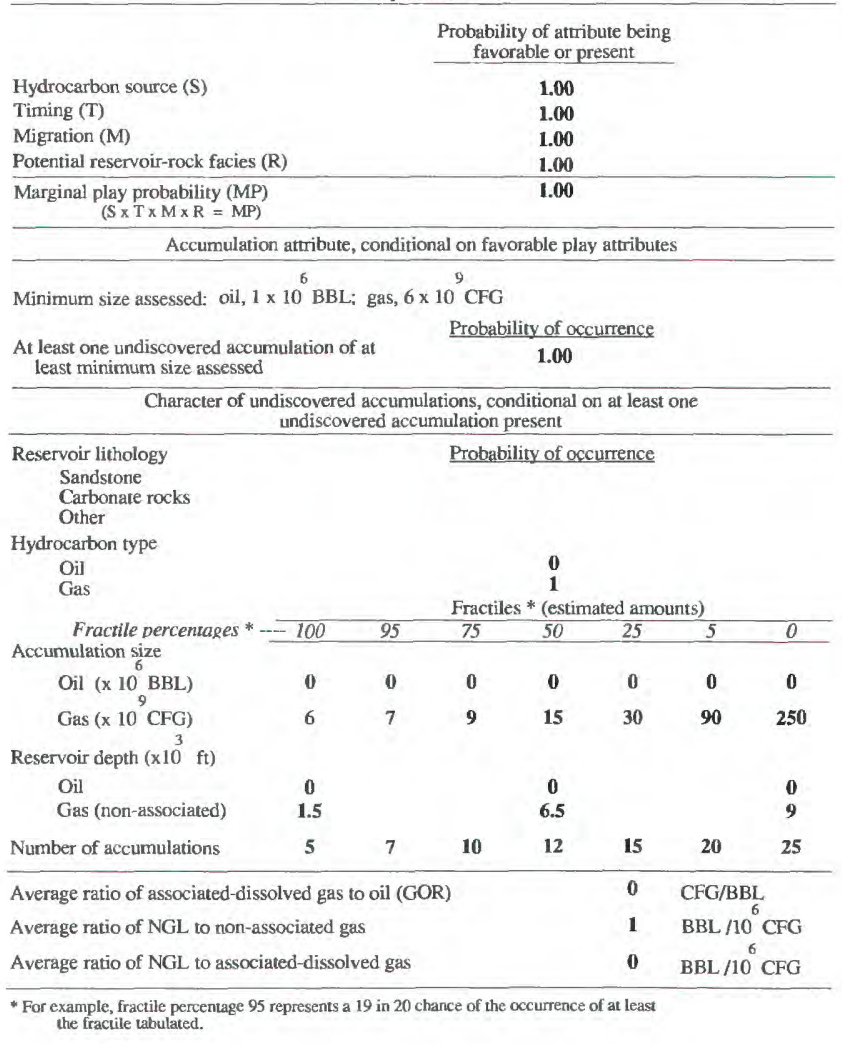




\section{STARKEY-WINTERS PLAY (030)}

The Starkey-Winters play consists of gas accumulations in stratigraphic and growth fault traps in Late Cretaceous marine sandstones and, in the south end of the basin and western Delta depocenter, in sandstone units that conformably overlie lowermost Paleocene marine clastic rocks. The play covers about $4,820 \mathrm{mi}^{2}$. Sandstone units occur in the Winters and Mokelumne River Formations north of the Stockton fault zone, and in the upper part of the Panoche Group and Moreno Formation south of the Stockton fault zone (fig. 39). These sandstone units constitute part of the southward and westward progradational depositional system that, with interspersed transgressive phases, eventually led to the filling of the Sacramento basin. The transgressive Sacramento Formation forms the lower stratigraphic boundary of the Starkey-Winters play. The upper stratigraphic boundary in most places is an unconformity that is overlain by the (1) Eocene marine Capay Formation in the north, (2) Paleocene marine Martinez Formation or Paleogene submarine canyon fill in the Delta depocenter, and (3) nonmarine Neogene rocks south of the Stockton fault zone. The Paleocene Martinez Formation conformably overlies this play locally in the western Delta depocenter.

North of the Stockton fault zone, reservoirs include basinal sandstone units of the Winters Formation, and shelf (largely deltaic) sandstone units composing the Starkey sands of local usage of the Winters and Mokelumne River Formations. South of the Stockton fault zone, widely used nomenclature places stratigraphic and generally age equivalent basinal and slope reservoir sandstones in the upper part of the Panoche Group and Moreno Formation (for example, the Lathrop sands of local usage). Discovered reservoirs occur at depths from about 1,000 to $7,800 \mathrm{ft}$, thicknesses are 3-315 ft, and porosities are generally between 15 and 34 percent. The main sources of thermogenic gas are Cretaceous shale in the deepest parts of the basin, although other sources and a mixture of sources probably contributed gas in some of the fields. Gas generation is believed to have commenced by the end of Cretaceous time, or earlier in the Delta depocenter. Gas is produced from stratigraphic and structural traps in deltaic and submarine fan reservoirs. In deltaic facies, both delta-front and distributary-channel sandstones of the Starkey sands and the Mokelumne River Formation are productive in traps formed by stratigraphic pinchouts and growth faults. Traps in submarine fan deposits (Lathrop gas field) are mainly in midfan facies, either in structurally high suprafan mounds or along lateral fan margins near the base of the slope where sandstone units onlap, pinch out, and are sealed against slope shale.

Principal gas fields in the play (with year of discovery and cumulative production plus estimated reserves through 1986) are Lathrop (1961, $358 \mathrm{BCF})$, Union Island (1972, 250 BCF), Lindsay Slough (1962, 237 BCF), McDonald Island (1936, 184 BCF), Rio Vista (1943, 175 BCF), and Millar (1944, 139 BCF). Cumulative production plus estimated reserves of gas through 1986 in 73 fields is $2.5 \mathrm{TCF}$.

The play is mature, but future potential for gas in mainly smaller fields in the less well explored lower and upper submarine fan facies of the Winters Formation, and its lateral equivalents to the south, is estimated as fair to good. 


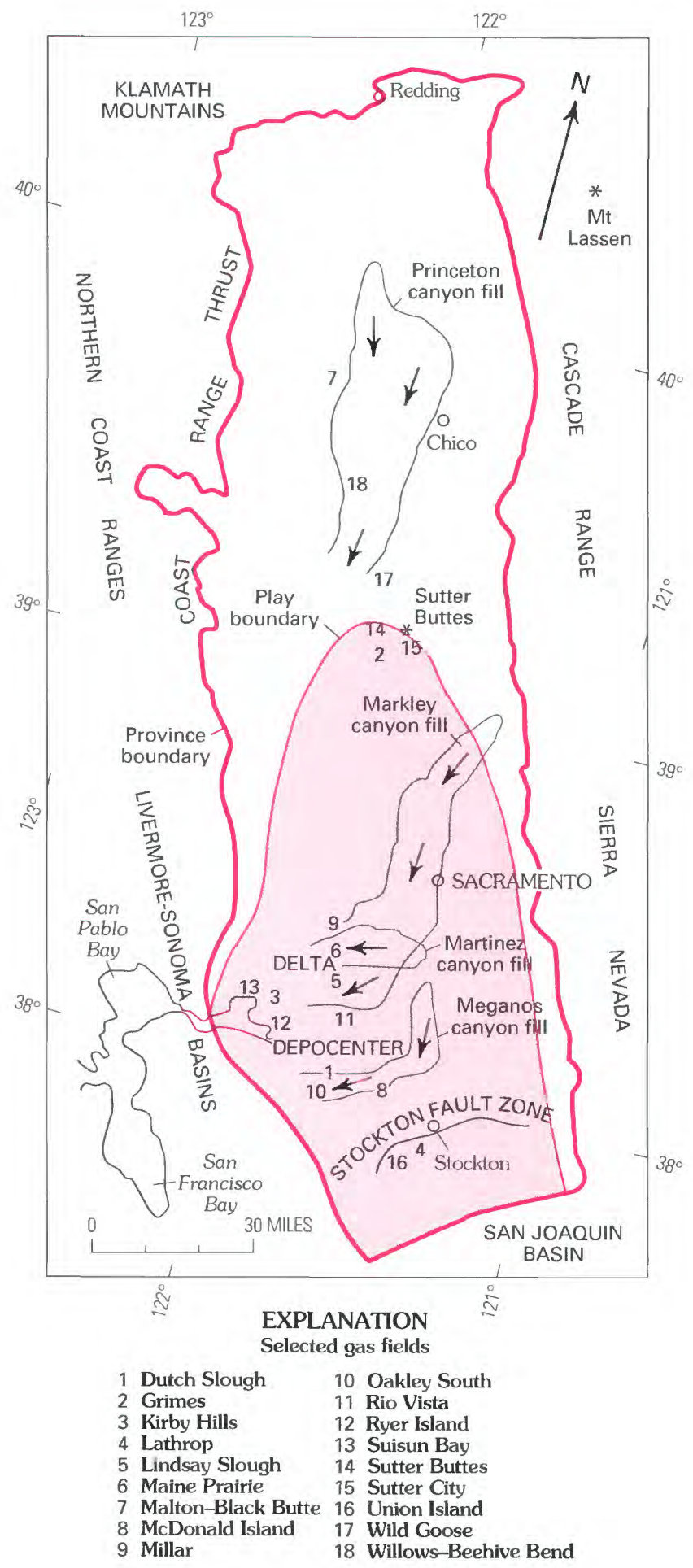

Figure 39. Map of Starkey-Winters play (073-030).

OIL AND GAS PLAY DATA

PLAY STARKEY-WINTERS

PROVINCE SACRAMENTO BASIN

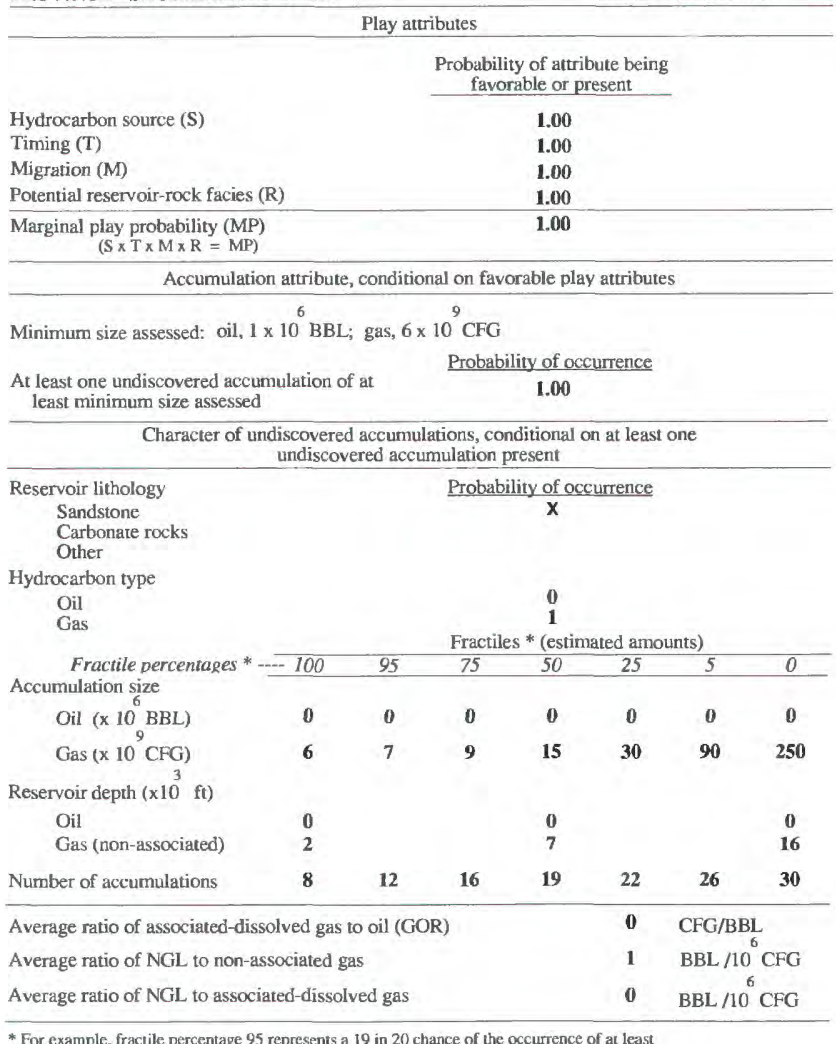

For example, fracuile percentage 95 represents a 19 in 20 chance of the occurrence of at least
the fracule tabulated. 


\section{GUINDA-KIONE-FORBES PLAY (040)}

The Guinda-Kione-Forbes play is characterized by gas fields that produce mainly from Upper Cretaceous marine clastic reservoirs in stratigraphic and structural traps in the upper part of the Great Valley sequence. Reservoirs occur in Kione sands of local usage in the Forbes Formation, pre-Forbes strata, mainly in the Guinda sand of local usage, and in their equivalents. The play encompasses about $11,120 \mathrm{mi}^{2}$ and covers all of the Sacramento Basin province, because parts of the Great Valley sequence underlie the entire area (figs. 37, 40). The upper stratigraphic boundary of the play is the transgressive Sacramento Formation or its lateral equivalents except in the northern play area, where Kione sands (deltaic sandstone facies) of the Forbes Formation are unconformably overlain by either the Eocene Capay Formation, the so-called Princeton canyon fill, or younger nonmarine rocks.

All significant gas reservoirs of the play are in the Kione sands (deltaic sandstone) and other more distal facies of the Forbes Formation in the northern basin area. In addition, minor gas reservoirs are also productive in underlying strata of the Guinda sand in this area. Southward in the basin, uneconomic to minor Forbes gas accumulations have been discovered on the eastern shelf, in the Kirby Hills field along the west side, and possibly in the western Delta depocenter. Elsewhere, in the deeper southern part of the basin, the top of the Forbes occurs at depths of about $10,000-14,000 \mathrm{ft}$, and sparse drilling has not found economic gas accumulations. Discovered reservoirs occur at depths from 1,000 to $3,200 \mathrm{ft}$, and have thicknesses of 5-70 ft and porosities generally between 15 and 33 percent.

Gas in the northern part of the basin may be largely thermogenic, probably derived from deeply buried, gas-prone Cretaceous shale and mudstone along the western margin and, possibly, from the now-missing western part of the Cretaceous forearc basin. Gas with higher nitrogen content on the eastern flank of the basin may be derived largely, or in part, from metasedimentary rocks located deep beneath the basement. Gas generation is thought to have commenced by the end of Cretaceous time, or earlier in the Delta depocenter. Oil seeps in rocks of the Great Valley sequence, near the structural contact with the Jurassic and Cretaceous Franciscan assemblage along the western margin of the province, may come from oil-prone basal units on the never-deeply-buried oceanward side of the forearc basin, or early forearc slope sediments possibly deposited in an early, anoxic, restricted circulation phase of forearc basin development. Traps are mainly stratigraphic-structural involving sandstone pinchouts updip and across structural noses. Faulted fold traps are less common.

Principal gas fields in the play (with year of discovery and cumulative production plus estimated reserves through 1986) are the Grimes (1960, $638 \mathrm{BCF})$, Willows-Beehive Bend $(1938,371$ BCF), Sutter Buttes (1933, 187 BCF), Malton-Black Butte (1964, 113 BCF), Sutter City (1952, 105 BCF), and Wild Goose (1951, 103 BCF). Cumulative production plus estimated reserves of gas through 1986 in 48 fields is 2.09 TCF.

Fair to good potential exists for undiscovered gas resources in the play, including the Guinda-Kione-Forbes section in the northern part of Sacramento basin, speculative Forbes or pre-Forbes reservoirs at depths greater than $14,000 \mathrm{ft}$ in the southern basin area, and in very speculative, pre-Guinda reservoirs. 


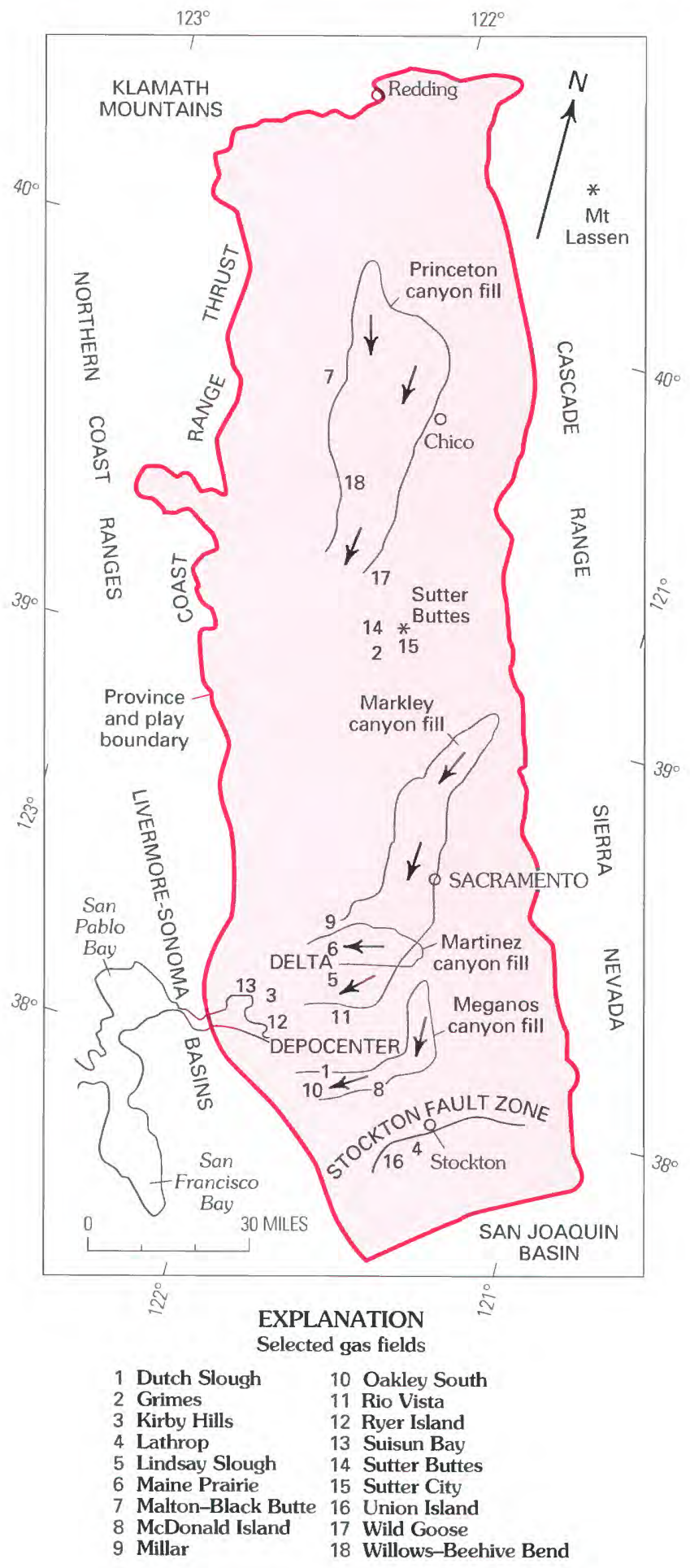

Figure 40. Map of Guinda-Kione-Forbes play (073-040).

PLAY

OIL AND GAS PLAY DATA

GUINDA-KIONE-FORBES

PROVINCE SACRAMENTO BASIN

\begin{tabular}{lc}
\hline \multicolumn{2}{c}{ Play attributes } \\
\hline & $\begin{array}{c}\text { Probability of attribute being } \\
\text { favorable or present }\end{array}$ \\
\cline { 2 - 2 } Hydrocarbon source (S) & 1.00 \\
Timing (T) & 1.00 \\
Migration (M) & 1.00 \\
Potential reservoir-rock facies (R) & 1.00 \\
\hline Marginal play probability (MP) & 1.00 \\
\hline \multicolumn{2}{c}{$(\mathrm{S}$ × T x M R R MP) } \\
\multicolumn{2}{c}{ Accumulation attribute, conditional on favorable play attributes } \\
\hline
\end{tabular}

Minımum size assessed: oil, $1 \times 10^{6} \mathrm{BBL}$; gas, $6 \times 10^{9} \mathrm{CFG}$

Arobability of occurrence

At least one undiscovered accun
least minimum size assessed

Character of undiscovered accumulations, conditional on at least on

Reservoir lithology
Probability of occurrence
$X$

Sandsione

Carbonate rocks

Other

Hydrocarbon type

Oil
Gas

1

Fractiles * (estimated amounts) Accumulation size

$\begin{array}{llllllll}\text { Oil }(x 10 \text { BBL }) & 0 & 0 & 0 & 0 & 0 & 0 & 0\end{array}$

$\begin{array}{llllllll}\operatorname{Gas}\left(\times 10^{9} \mathrm{CFG}\right) & 6 & 6.3 & 8 & 11 & 22 & 90 & 530\end{array}$

Reservoir depth $\left(x 10^{3} \mathrm{ft}\right)$

Oil $\quad 0 \quad 000$

$\begin{array}{llllllll}\text { Gas (non-associated) } & 2 & & & 11 & & 19 \\ & 5 & 8 & 12 & 15 & 20 & 28 & 35\end{array}$

$\begin{array}{lllll}12 & 15 & 20 & 28 & 35\end{array}$

$\begin{array}{lll}\text { Average ratio of associated-dissolved gas to oil (GOR) } & 0 & \text { CFG/BBL } \\ \text { Average ratio of NGL to non-associated gas } & 0 & \text { BBL } / 10^{6} \mathrm{CF}\end{array}$

Average ratio of NGL to associated-dissolved gas

- BBL $/ 10^{6} \mathrm{CFG}$ 


\title{
SAN JOAQUIN BASIN PROVINCE (074)
}

\author{
By Larry A. Beyer \\ INTRODUCTION
}

The San Joaquin basin, which occupies the south half of the Great Valley of California, is an asymmetrical structural trough filled with up to $30,000 \mathrm{ft}$ of Cretaceous and Cenozoic marine clastic rocks (fig. 41). The northern basin area formed as part of a Cretaceous-Paleogene forearc basin. With some overlap to the north and with a transform-rifted western margin, the southern area subsided and was compressed during Neogene time, apparently in response to plate motions along the active California margin. The province, which is about $225 \mathrm{mi}$ long and averages $65 \mathrm{mi}$ wide, is bordered on the east by the Sierra Nevada, on the south by the northern transverse ranges, on the west by the San Andreas fault zone and the southern Diablo Range, and arbitrarily on the north by the Stanislaus-San Joaquin County line.

Major oil fields, with estimated recoverable oil and gas through 1986, are MidwaySunset (2.252 BBO, 569 BCF), Kern River (1.948 BBO, 4 BCF), Elk Hills (1.473 BBO, 1.812 TCF), South Belridge (1.111 BBO, 340 BCF), and Coalinga (906 MMBO, $226 \mathrm{BCF}$ ). Cumulative production of oil and gas from 102 fields in the province through 1986 was $9.484 \mathrm{BBO}$ and 10.477 TCF. The largest fields were discovered in the late 1800's and early 1900's. The last major discovery (Yowlumne) occurred in 1974. Oil production has continued to increase due to reservoir extensions, new pool discoveries, and improved recovery techniques in existing large fields. Seven plays were individually assessed in the San Joaquin basin: Southern Post-Miocene, Southwest Upper Miocene, Miocene Fractured Diatomaceous, Southeast Eocene-Pleistocene, East Pre-Pliocene, West Pre-Upper Miocene, and Northern Pre-Pliocene. 
REGION 1, ALASKA; REGION 2, PACIFIC COAST

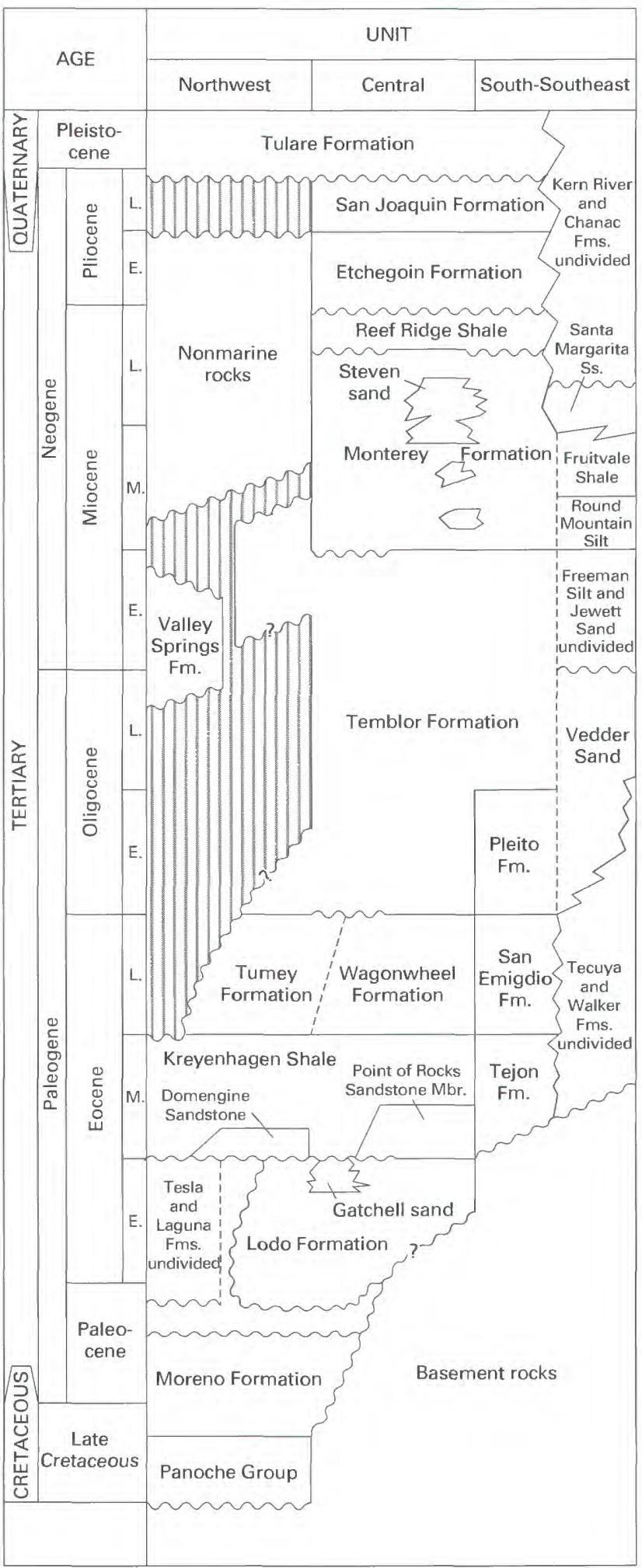

Figure 41. Generalized stratigraphic column, San Joaquin Basin province (074). Contact dashed where speculative. Wavy line, unconformity; queried where uncertain. 


\section{SOUTHERN POST-MIOCENE PLAY (020)}

The play consists of oil and nonassociated gas fields that produce from sandstone reservoirs in stratigraphic and structural traps. The sandstone units represent the last sequence of Neogene marine transgressive-regressive cycles and Quaternary nonmarine deposition. The play covers about $3,880 \mathrm{mi}^{2}$ in the south-central and southwest areas of the San Joaquin basin (fig. 42). Rocks of the play share a simple burial history and generally are less deformed than the upper Miocene and older rocks which they unconformably overlie.

Sandstone reservoirs that contain nonassociated gas occur in a transgressive marine sequence of Pliocene age that grades upward into Pleistocene deltaic and nonmarine rocks. Discovered reservoirs, largely in Pliocene rocks of the Etchegoin and San Joaquin Formations, occur at depths of less than 1,000 to about 4,900 ft; thicknesses are mostly less than $30 \mathrm{ft}$ and porosities generally range from 25 to 35 percent. Gas presumably has migrated upward along faults and other permeable routes since latest Neogene time after thermal generation in Cretaceous, Eocene, and (or) Miocene source rocks, although some of the shallow gas may be biogenic in origin. Discovered traps, mostly formed since latest Neogene time, consist of gently folded and faulted anticlines.

Marine to nonmarine sandstone reservoirs of Pliocene to Pleistocene age also produce large quantities of low-gravity oil from the Etchegoin, San Joaquin, and Tulare Formations along the southwestern margin of the play area. Discovered reservoirs occur at depths of about $330 \mathrm{ft}$ to more than $7,900 \mathrm{ft}$ in basinward locations; thicknesses range from about 10 to $65 \mathrm{ft}$ and porosities generally from 20 to 35 percent. Oil probably has migrated from the underlying organic-rich, oil-prone shale of the Miocene Monterey Formation since latest Neogene time along numerous faults and other permeable routes. Discovered and anticipated traps, mostly formed since latest Neogene time, include anticlines, faults, reservoir pinchouts, truncations, and permeability barriers. In some Pleistocene reservoirs, ground-water movement has controlled the final accumulation of oil. Seals are low-permeability claystone, tightly cemented sandstone, and tar zones.

Principal nonassociated gas fields (with year of discovery and cumulative production plus estimated reserves through 1984) are Elk Hills (1919, 319 BCF), Trico (1934, 201 BCF), and Buena Vista (1909, 89 BCF). Principal low-gravity oil fields (with year of discovery and cumulative production plus estimated reserves through 1984) are Midway-Sunset (1894, $1.317 \mathrm{BBO}, 258 \mathrm{BCF})$, South Belridge (1911, $587 \mathrm{MMBO})$, Buena Vista (1909, 572 MMBO, 917 BCF), Elk Hills (1911, 494 MMBO, 540 BCF), McKittrick (1896, $189 \mathrm{MMBO}, 16 \mathrm{BCF})$, and Lost Hills (1910, $160 \mathrm{MMBO}, 173 \mathrm{BCF})$. Cumulative production plus estimated reserves of oil and gas through 1984 from the 21 significant fields in the play are $4.12 \mathrm{BBO}$ and $2.60 \mathrm{TCF}$, respectively. The play is very mature and has a low to moderate future potential for undiscovered resources in small fields. Total recoverable oil in known fields will continue to increase due to improved recovery techniques and reservoir extensions. 


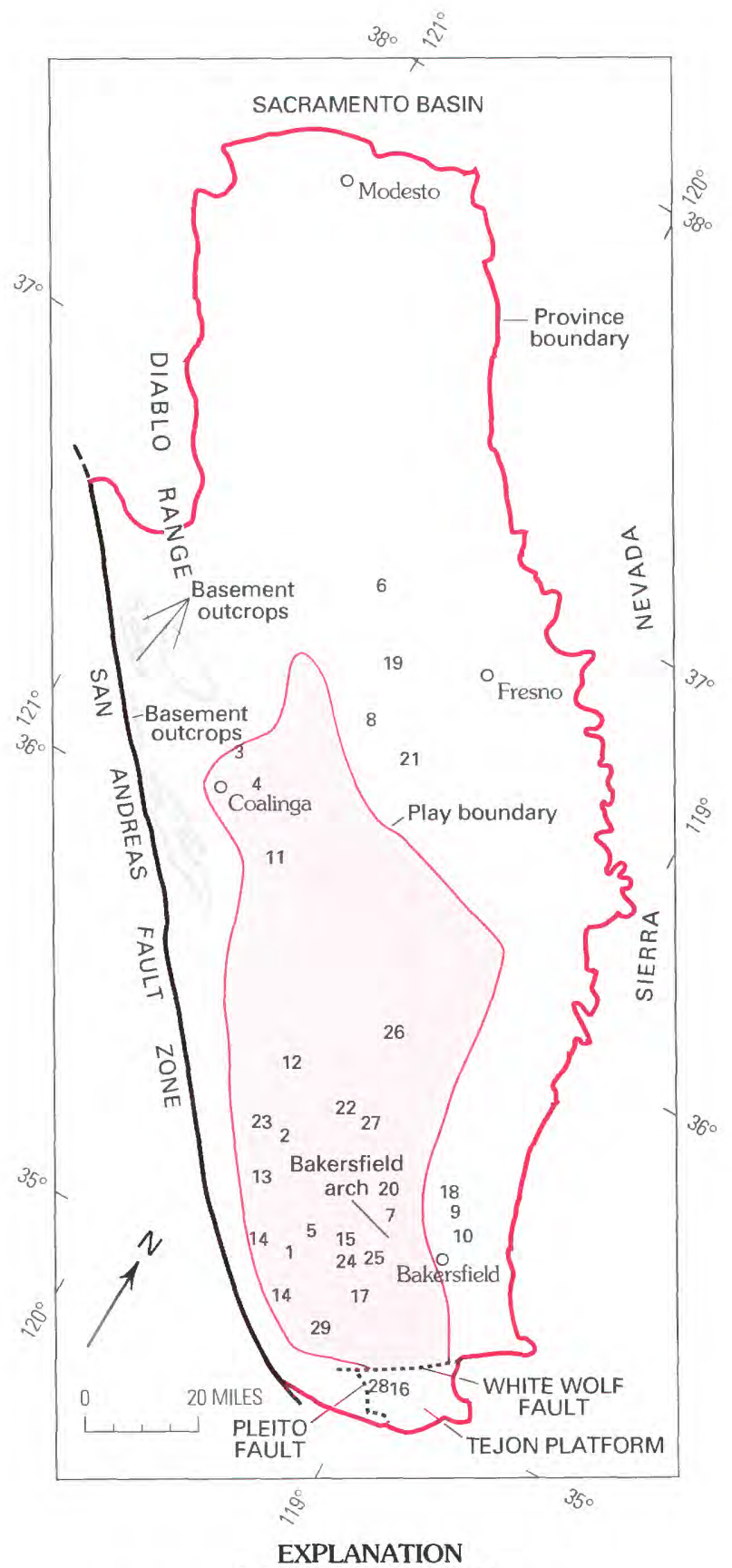

Selected oil and gas fields

$\begin{array}{ll}1 \text { Buena Vista } & 16 \text { North Tejon } \\ 2 \text { Cal Canal } & 17 \text { Paloma } \\ 3 \text { Coalinga } & 18 \text { Poso Creek } \\ 4 \text { Coalinga East Extension } & 19 \text { Raisin City } \\ 5 \text { Elk Hills } & 20 \text { Rio Bravo } \\ 6 \text { Gill Ranch } & 21 \text { Riverdale } \\ 7 \text { Greeley } & 22 \text { Semitropic } \\ 8 \text { Helm } & 23 \text { South Belridge } \\ 9 \text { Kern Front } & 24 \text { South Coles Levee } \\ 10 \text { Kern River } & 25 \text { Ten Section } \\ 11 \text { Kettleman North Dome } & 26 \text { Trico } \\ 12 \text { Lost Hills } & 27 \text { Wasco } \\ 13 \text { McKittrick } & 28 \text { Wheeler Ridge } \\ 14 \text { Midway-Sunset } & 29 \text { Yowlumne } \\ 15 \text { North Coles Levee } & \end{array}$

Figure 42. Map of Southern Post-Miocene play (074-020).

PLAY SOUTHERN POST-MIOCENE

PROVINCE SAN JOAQUIN BASIN

CODE 02-074-020

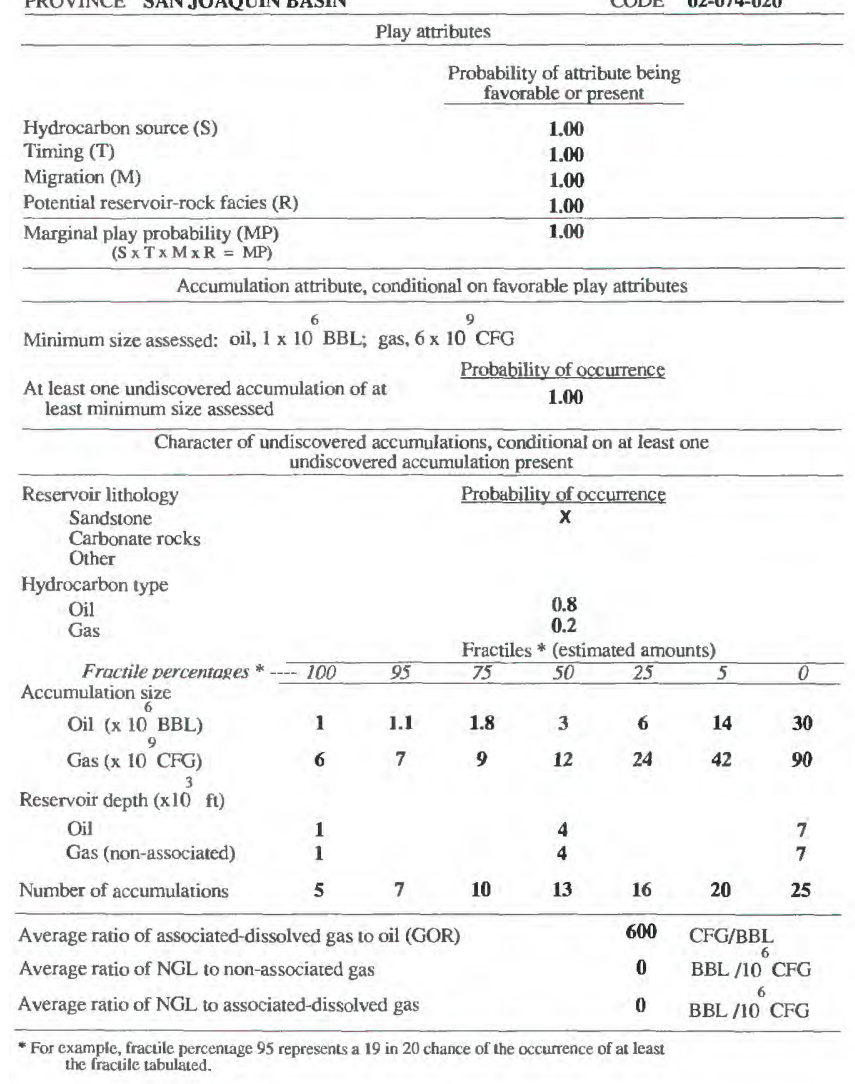




\section{SOUTHWEST UPPER MIOCENE PLAY (030)}

The play consists of stratigraphic and structurally trapped oil and associated gas accumulations in discontinuous and sinuous upper Miocene sandstone reservoirs largely enclosed in fine-grained siliceous rocks, also of late Miocene age. The play covers about $760 \mathrm{mi}^{2}$ in the southwest San Joaquin basin (fig. 43). The sandstone units are thought to be submarine canyon deposits, proximal to distal turbidite deposits, that came from a steep, plutonic source terrane located nearby to the west and southwest. Some of the sandstone units have been traced as channels for many miles; others are thick bodies with little areal extent. Portions of this common depositional system were removed by uplift and erosion, particularly along the western and southwestern margins of the play area. Reservoirs of this play are more highly deformed than the unconformably overlying rocks of the Southern Post-Miocene Play (020).

Reservoirs occur as intervals within the Reef Ridge Shale and Monterey Formation (fig. 41) and are referred to locally by names such as Leutholtz, Williams, Moco, Webster, Yowlumne, Monarch, Lakeview, 26R, and 24Z sands. Discovered reservoirs occur at depths of several hundred feet to about $12,000 \mathrm{ft}$ and are as much as $500 \mathrm{ft}$ thick. Porosities generally are between 25 and 35 percent at depths above $7,900 \mathrm{ft}$ and in the 10- to 20-percent range in more distal turbidite facies at depths of as much as $12,000 \mathrm{ft}$. Organic-rich, oil-prone shale of the Miocene Monterey Formation, which encases the sandstone reservoirs in many places, is believed to be the principal source of oil in the play. Oil generation is thought to have begun during late Miocene time or earlier and generally coincided with early trap formation. Discovered and anticipated traps include pinchouts, tilted lenses, folded or domed channel and lobe sandstones, differential compaction of shale over these lobes, faults, and diagenetic permeability barriers. Depths to traps range from several hundred feet to about $12,000 \mathrm{ft}$.

Principal fields (with year of discovery, dates of production, and cumulative production plus estimated reserves through 1984) are Elk Hills (1941-1973, 835 MMBO, 1.13 TCFG) and Midway-Sunset (1900-1957, 669 MMBO, 206 BCFG). More recently discovered smaller fields include Yowlumne (1974, 83 MMBO, 87 BCFG) and Cal Canal (1977, 8 BCFG and condensate). Cumulative production plus estimated reserves of oil and gas through 1984 from the 12 fields in the play are $2.06 \mathrm{BBO}$ and 1.95 TCFG, respectively. The play is very mature, but future potential is fair to good for undiscovered oil or condensate in accumulations reaching intermediate size. 


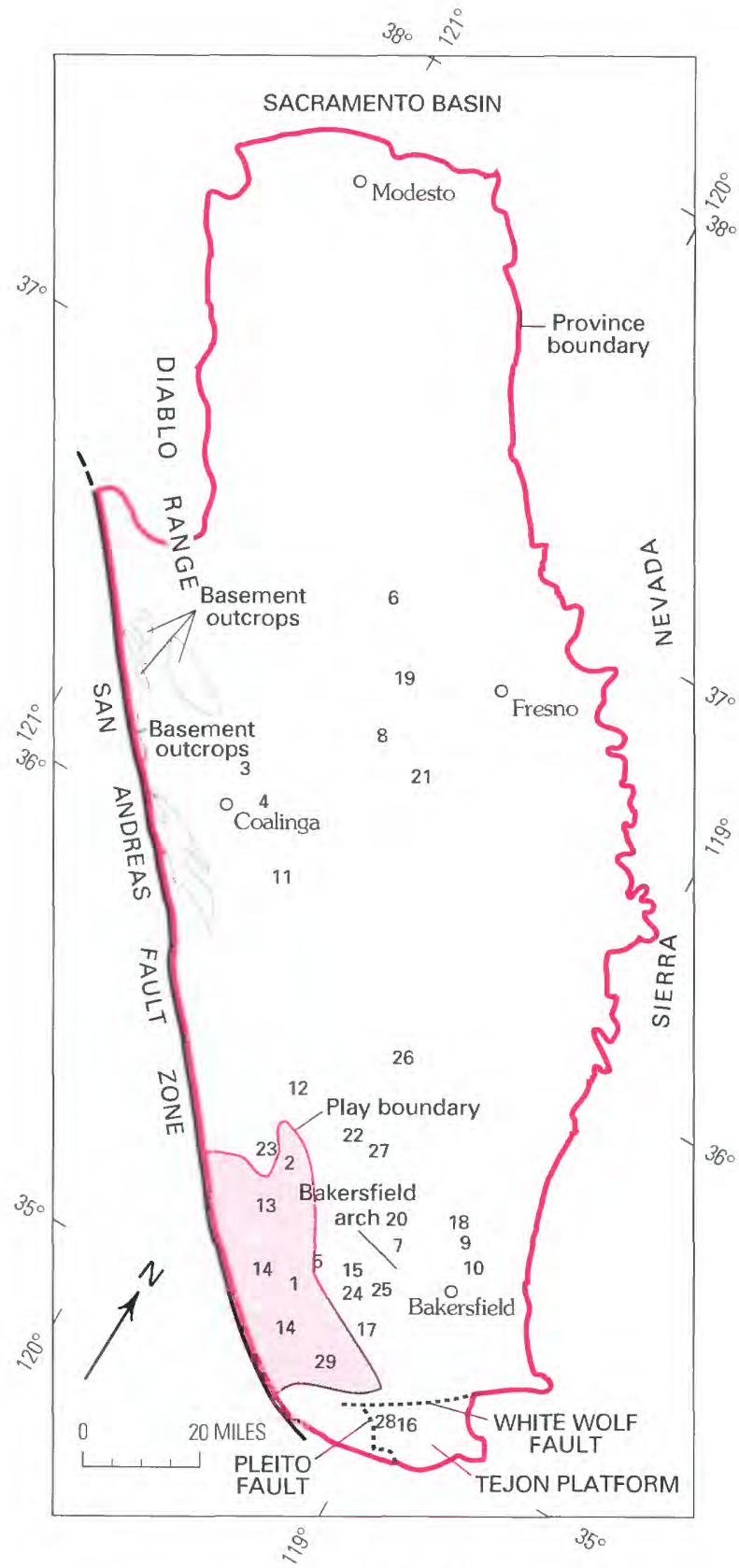

EXPLANATION

Selected oil and gas fields

$\begin{array}{ll}1 & \text { Buena Vista } \\ 2 & \text { Cal Canal } \\ 3 & \text { Coalinga } \\ 4 & \text { Coalinga East Extension } \\ 5 & \text { Elk Hills } \\ 6 & \text { Gill Ranch } \\ 7 & \text { Greeley } \\ 8 & \text { Helm } \\ 9 & \text { Kern Front } \\ 10 \text { Kern River } \\ 11 \text { Kettleman North Dome } \\ 12 \text { Lost Hills } \\ 13 \text { McKittrick } \\ 14 \text { Midway-Sunset } \\ 15 \text { North Coles Levee }\end{array}$

16 North Tejon

17 Paloma

18 Poso Creek

19 Raisin City

20 Rio Bravo

21 Riverdale

22 Semitropic

23 South Belridge

24. South Coles Levee

25 Ten Section

26 Trico

27 Wasco

28 Wheeler Ridge

29 Yowlumne
Figure 43. Map of Southwest Upper Miocene play (074-030).

PLAY SOUTHWEST UPPER MIOCENE

OIL AND GAS PLAY DATA PROVINCE SAN JOAOUIN BASIN

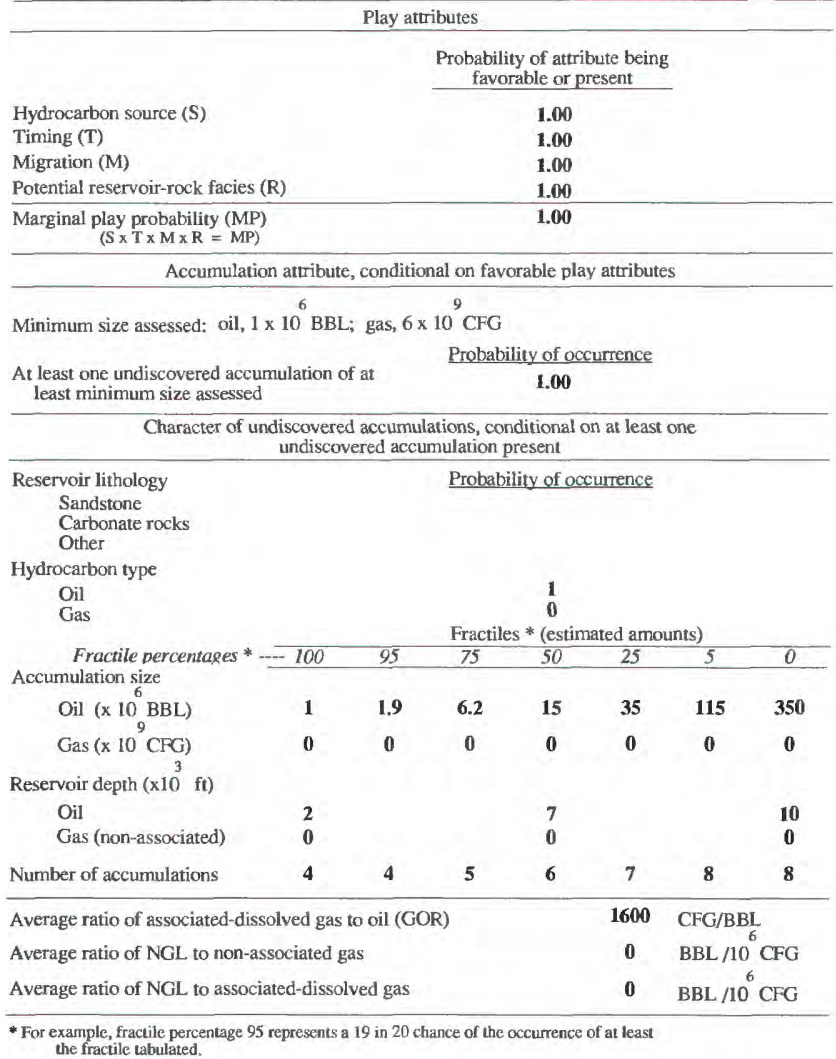




\section{MIOCENE FRACTURED DIATOMACEOUS PLAY (040)}

The play consists of oil and associated gas fields in structural traps in fine-grained, siliceous sedimentary rock reservoirs. The play covers about $3,530 \mathrm{mi}^{2}$ in the southwest part of the San Joaquin basin and is bordered on the west by the San Andreas fault zone (fig. 44). Rocks of the play are composed of biogenous material, clay, and silt with sand lenses and partings in some locations. These strata were deposited in a largely anoxic basin during middle and late Miocene time. The rock sequence makes up the finegrained lithofacies of the Reef Ridge Shale, three members of the Monterey Formation that are widely distributed in the southwestern part of the basin, and parts of the Fruitvale Shale in the southeastern part of the basin (fig. 41). This sequence ranges in thickness from 1,500 to $9,800 \mathrm{ft}$. Where not significantly diluted with terrigenous sediment and not deeply buried, reservoirs are diatomaceous, and porosities can reach 60 percent. At greater burial depths, diagenetically altered equivalents of the diatomaceous reservoir rocks are porcelaneous shale and hard, quartz-rich rocks that possess relatively low intergranular porosity but may be naturally fractured.

Known reservoirs include diatomaceous intervals of the Reef Ridge Shale (for example, Belridge diatomite of local usage) and naturally fractured intervals of the Monterey Formation (for example, Cahn zone). Diatomaceous reservoirs occur at average depths from 1,000 to $2,200 \mathrm{ft}$; thicknesses range from 150 to $1,320 \mathrm{ft}$ and porosities between 45 and 55 percent. Discovered fractured shale reservoirs occur at depths from 3,200 to $6,700 \mathrm{ft}$, range in thickness from 50 to $2,500 \mathrm{ft}$, and generally have low intergranular porosity.

Diatomaceous reservoirs were sourced by the deeply buried, oil-prone shale of the Monterey Formation. More deeply buried fractured, quartz-rich shale reservoirs may be partly or wholly their own source rock. Oil generation is believed to have begun in middle to late Miocene time and continued to the present, with oil migrating through fracture and fault systems to traps formed since the late Miocene. Known traps include faulted anticlines and fractured intervals that may have resulted from tectonic and (or) diagenetic effects.

Principal fields (with year of discovery and (or) years of production and cumulative production plus estimated reserves through 1984) are South Belridge (1911, 303 MMBO, 279 BCFG), Midway-Sunset (1925-1975, 105 MMBO, 52 BCFG), Elk Hills (1941, 91 MMBO, 126 BCFG), Lost Hills (1913-1979, 45 MMBO, 187 BCFG), and Buena Vista (1952, 33 MMBO, 206 BCFG). Cumulative production plus estimated reserves of oil and gas through 1984 from the seven fields in the play are 0.64 BBO and 0.91 TCFG, respectively.

Diatomaceous rocks in the play represent a substantial volume of the Neogene basin fill in the southwest quadrant of the San Joaquin Basin province. Although some oil had been produced from these rocks for many years, the discovery of deeper fractured reservoirs in existing fields over the past 20 years, and extensive fracture stimulation of large known reservoirs begun in 1980, have greatly improved production. In addition, extraction of oil from quarried surface deposits of the same rocks was successful in pilot studies. Additional oil resources may be discovered in the more brittle, naturally fractured rocks in unexplored areas, and new reserves are likely to be developed in known fields. The play is mature, but the potential for future undiscovered resources is considered fair to good. 


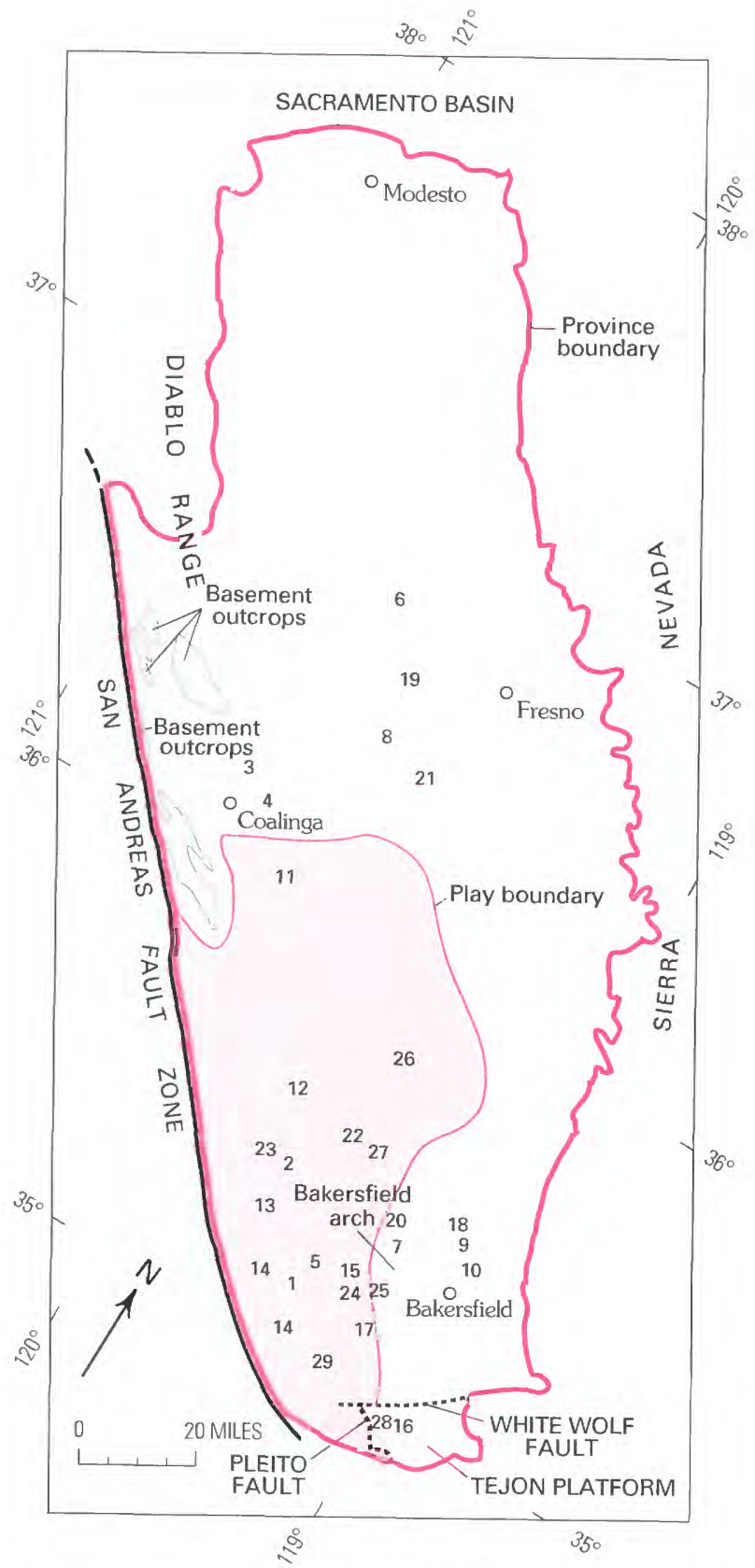

EXPLANATION

Selected oil and gas fields

$\begin{array}{ll}1 \text { Buena Vista } & 16 \text { North Tejon } \\ 2 \text { Cal Canal } & 17 \text { Paloma } \\ 3 \text { Coalinga } & 18 \text { Poso Creek } \\ 4 \text { Coalinga East Extension } & 19 \text { Raisin City } \\ 5 \text { Elk Hills } & 20 \text { Rio Bravo } \\ 6 \text { Gill Ranch } & 21 \text { Riverdale } \\ 7 \text { Greeley } & 22 \text { Semitropic } \\ 8 \text { Helm } & 23 \text { South Belridge } \\ 9 \text { Kern Front } & 24 \text { South Coles Levee } \\ 10 \text { Kern River } & 25 \text { Ten Section } \\ 11 \text { Kettleman North Dome } & 26 \text { Trico } \\ 12 \text { Lost Hills } & 27 \text { Wasco } \\ 13 \text { McKittrick } & 28 \text { Wheeler Ridge } \\ 14 \text { Midway-Sunset } & 29 \text { Yowlumne } \\ 15 \text { North Coles Levee } & \end{array}$

Figure 44. Map of Miocene Fractured Diatomaceous play (074-040).
MIOCENE FRACTURED DIATOMACEOUS

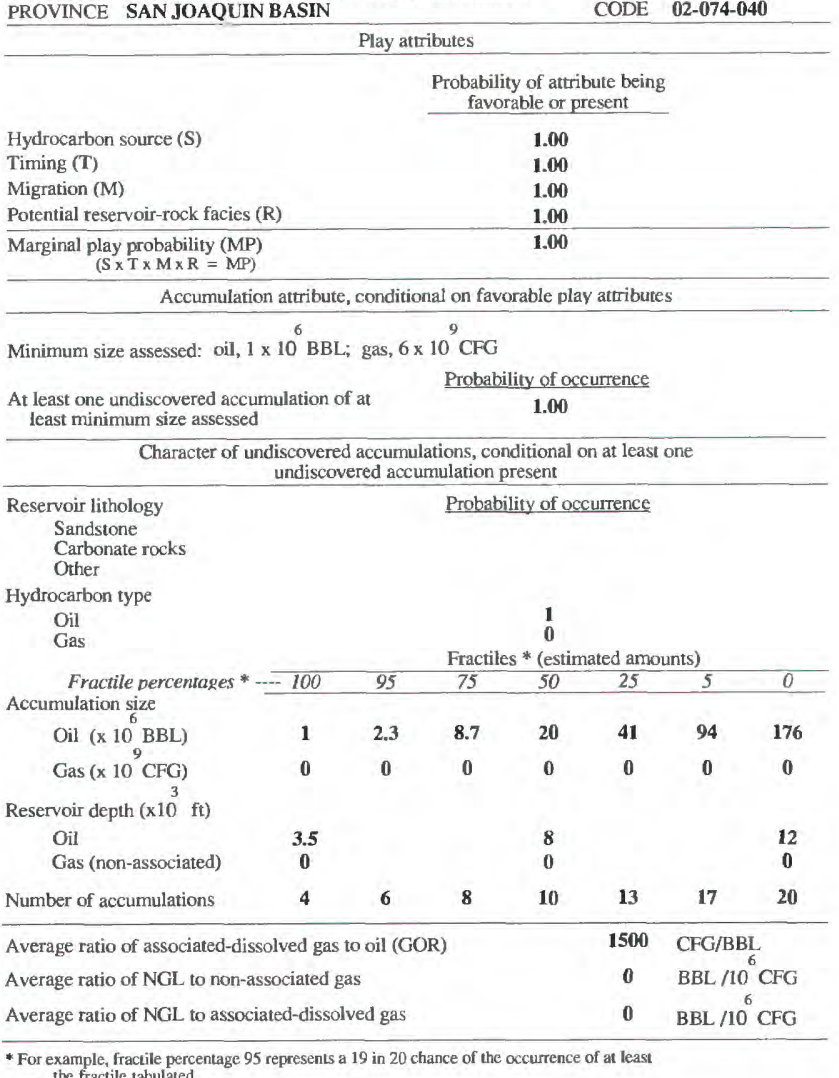




\section{SOUTHEAST EOCENE-PLEISTOCENE PLAY (050)}

The play consists of oil and gas fields in a variety of trap types in sandstone reservoirs consisting mostly of upper slope, shelf, and nonmarine facies sourced from the east and southeast. The play covers about $880 \mathrm{mi}^{2}$, extending from north of Bakersfield to the southeast corner of the basin and westward across the Tejon platform (fig. 45). Deltaic, fluvial and terrestrial wedges, shelf, channel and slope (ramp?) deposits, and, more basinward, a few turbidites also characterize this play. Deposition has been controlled since latest Eocene time by basin subsidence, eustatic sea level changes, and successive uplift of the basin margin and adjacent source areas. Fractured basement reservoirs, found in only two fields to date, are also grouped in this play for assessment purposes.

North of the White Wolf fault, reservoirs produce from practically every formation, ranging in age from Oligocene to Pleistocene(?), and include the Vedder Sand, Freeman Silt, Jewett Sand, Santa Margarita Sandstone, and Chanac and Kern River Formations. These reservoirs tend to wedge out or to be overlapped to the east, and to pass into deep-water facies to the west. Dips and folds are mostly gentle, and normal faults are common. Some gently folded anticlines are intensely faulted, but displacements are relatively small. Discovered reservoirs occur at depths from 165 to $9,800 \mathrm{ft}$; some are several hundred feet thick. Porosities range from 25 to 38 percent except in the deepest reservoirs, where they may be less than 20 percent. Known traps include faults, tar seals, or other permeability barriers, pinchouts, and truncations.

South of the White Wolf fault, and westward across the Tejon platform to the northeast-facing trace of the Pleito fault, reservoirs are of late Eocene to Miocene age, and include the Tejon and San Emigdio Formations, Vedder Sand, Jewett Sand, Freeman Silt, Round Mountain Silt, Fruitvale Shale, and Santa Margarita Sandstone. Discovered reservoirs occur at depths from 460 to $11,000 \mathrm{ft}$, and thickness ranges up to about $200 \mathrm{ft}$. Porosities vary from as low as 5-15 percent for deeply buried Eocene sandstone to as high as 35 percent for shallow Miocene shelf sandstone. Known traps include reservoir truncations, pinchouts, permeability barriers, normal faults on gently dipping anticlines, and, at the Wheeler Ridge field, a north-directed thrust fault on a prominent anticline. Source rocks for most reservoirs are thought to be the organic-rich, oil-prone shale of the Miocene Monterey Formation or Fruitvale Shale in deeper basinal areas that began generating oil during late Miocene time. The Eocene Kreyenhagen Shale, thought to have begun generating oil during middle Miocene time, probably is the source rock for some of the oldest, most basinward sandstone reservoirs in the northern play area. Numerous faults and other permeable routes aided migration to traps that had formed from late Miocene to present.

Principal oil and gas fields (with year of discovery and (or) years of production, and cumulative production plus estimated reserves through 1984) are Kern River (1899, 1.750 BBO, 4 BCFG), Kern Front (1912, 187 MMBO, 21 BCFG), Poso Creek (1920-1977, 87 MMBO, 10 BCFG), Wheeler Ridge (1922-1964, 32 MMBO, 21 BCFG), and North Tejon (1956-1960, 23 MMBO, 217 BCFG). Cumulative production plus estimated reserves of oil and gas through 1984 from the 12 fields in the play are $2.58 \mathrm{BBO}$ and $0.39 \mathrm{TCFG}$, respectively.

The play is mature and its future potential is low to moderate mainly in small fields, principally in structurally deeper areas, or in association with the White Wolf and other large faults. 


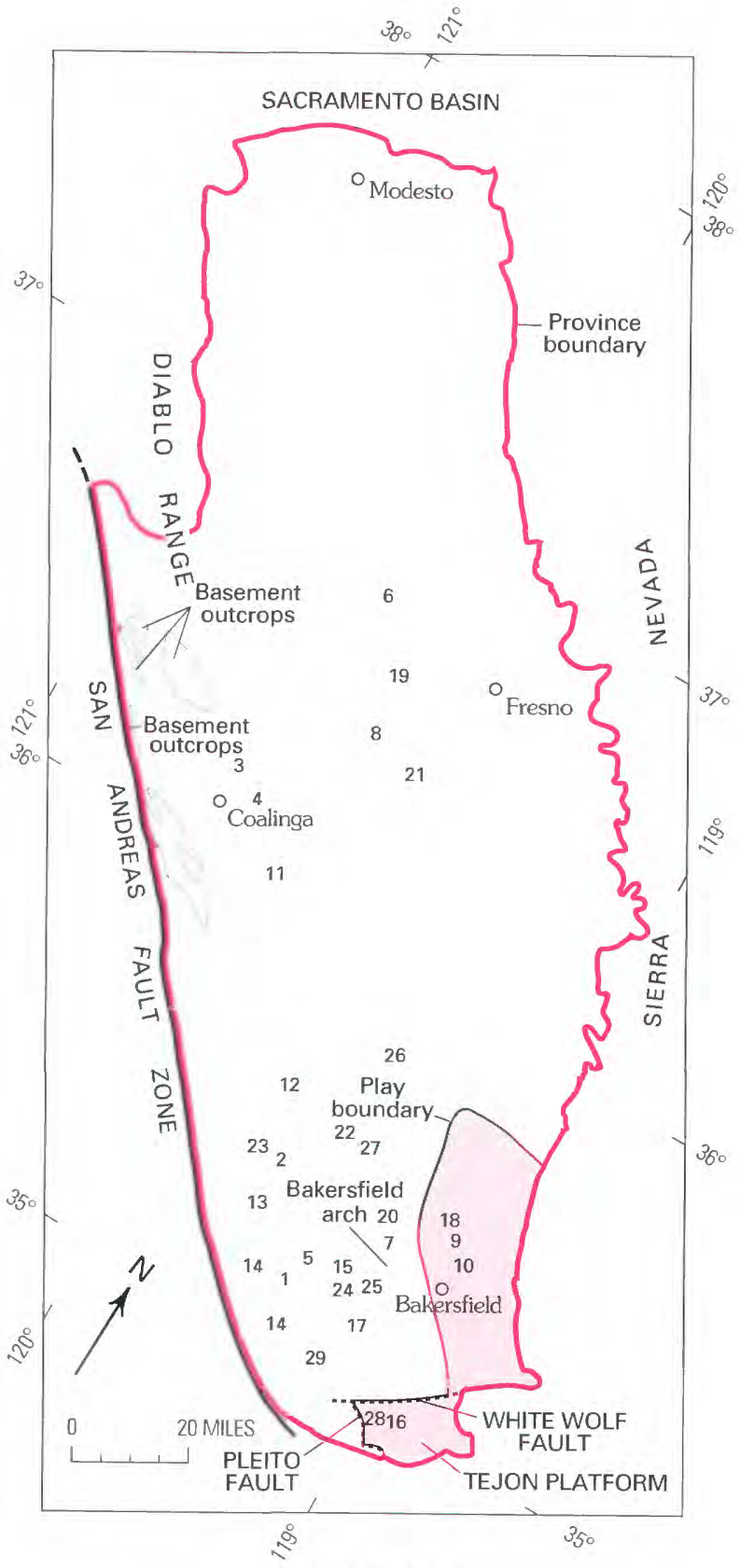

EXPLANATION

Selected oil and gas fields

$\begin{aligned} 1 \text { Buena Vista } & 16 \text { North Tejon } \\ 2 \text { Cal Canal } & 17 \text { Paloma } \\ 3 \text { Coalinga } & 18 \text { Poso Creek } \\ 4 \text { Coalinga East Extension } & 19 \text { Raisin City } \\ 5 \text { Elk Hills } & 20 \text { Rio Bravo } \\ 6 \text { Gill Ranch } & 21 \text { Riverdale } \\ 7 \text { Greeley } & 22 \text { Semitropic } \\ 8 \text { Helm } & 23 \text { South Belridge } \\ 9 \text { Kern Front } & 24 \text { South Coles Levee } \\ 10 \text { Kern River } & 25 \text { Ten Section } \\ 11 \text { Kettleman North Dome } & 26 \text { Trico } \\ 12 \text { Lost Hills } & 27 \text { Wasco } \\ 13 \text { McKittrick } & 28 \text { Wheeler Ridge } \\ 14 \text { Midway-Sunset } & 29 \text { Yowlumne } \\ 15 \text { North Coles Levee } & \end{aligned}$

Figure 45. Map of Southeast Eocene-Pleistocene play (074-050).

OIL AND GAS PLAY DATA

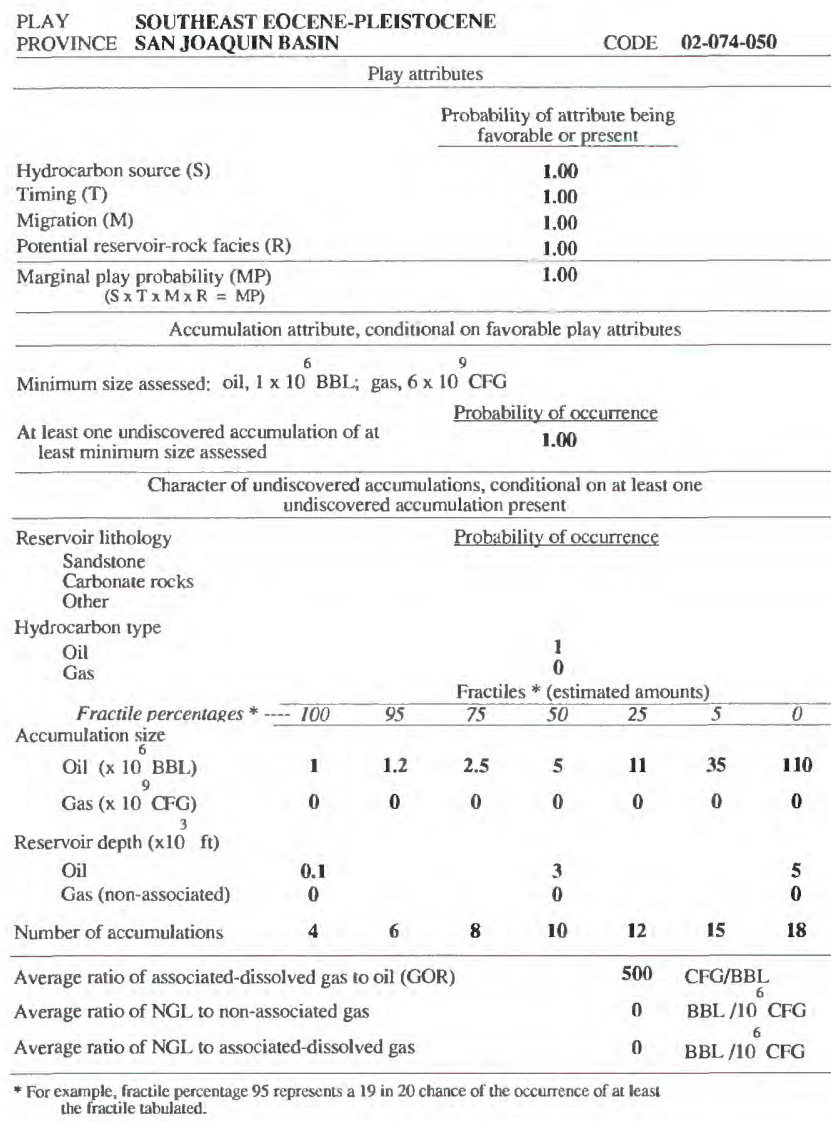




\section{EAST PRE-PLIOCENE PLAY (060)}

The play is characterized by oil and gas fields mostly in anticlinal and stratigraphic traps that produce mainly from Oligocene and Miocene slope and turbidite sandstone reservoirs derived from east and southeast sources. The play area, which covers about $1,080 \mathrm{mi}^{2}$, is bounded on the south by the White Wolf fault, and on the west and north by the limit of distribution of sediment from an eastern source (fig. 46). Reservoirs in the play are the westward and northward, more distal stratigraphic equivalents of rocks in the Southeast Eocene-Pleistocene Play (050).

The well-known Stevens sand of local usage, an upper Miocene sequence comprising as much as $3,900 \mathrm{ft}$ of turbidite sand with interbedded siltstone and shale, is the principal oil reservoir in most fields on the Bakersfield arch (fig. 46). Stevens reservoirs occur at depths from about 5,600 to more than $11,800 \mathrm{ft}$; thickness ranges from 5 to $320 \mathrm{ft}$ and porosities from about 14 to 33 percent. More distal facies of the Oligocene to Miocene Vedder and equivalent sandstone units have produced some oil from depths as great as 11,000-13,000 ft; thickness of these units ranges from 15 to $400 \mathrm{ft}$, porosities from about 15 to 24 percent. Smaller amounts of oil have been produced north of the Bakersfield arch from the Vedder Sand at a depth of 17,600 ft in the Semitropic field, and from other sandstones of Eocene(?) age at a depth of 15,000 ft in the Wasco field. Upper Eocene and Oligocene to Miocene sandstone reservoirs probably are also present in parts of the deep basin south of the Bakersfield arch and north of the White Wolf fault, but had not been reached by drilling through 1986. In addition, undivided Upper Cretaceous rocks, probably with poor reservoir properties, underlie Eocene rocks in some areas north of the Bakersfield arch.

Organic-rich, oil-prone shale of the Miocene Monterey Formation, thought to have been generating oil since late Miocene time, is the principal source rock for Stevens reservoirs. North of the Bakersfield arch, the Eocene Kreyenhagen Shale, which probably generated oil as early as middle Miocene time, is most likely the principal source rock for upper Eocene, Oligocene, and lower Miocene sandstone reservoirs north of the Bakersfield arch. Faults and other permeable routes have aided migration to traps formed largely from late Miocene time to the present. Known and anticipated hydrocarbon traps include anticlines, faulted anticlines, faulted homoclines, and stratigraphic traps with and without structural elements.

Principal oil and gas fields (with year of discovery and cumulative production plus estimated reserves through 1984) are North Coles Levee (1938, 161 MMBO, 244 BCFG), Rio Bravo (1937, 117 MMBO, 129 BCFG), Greeley (1936, 113 MMBO, 98 BCFG), Ten Section (1936, 82 MMBO, 165 BCFG), Paloma (1934, 42 MMBO, 399 BCFG), and South Coles Levee (1938, 31 MMBO, 420 BCFG). Cumulative production plus estimated reserves of oil and gas through 1984 from the 15 fields in the play are $0.77 \mathrm{BBO}$ and $1.82 \mathrm{TCFG}$, respectively.

This play is mature, but the deeper stratigraphic section remains only partly explored by drilling. Future potential for oil and gas in small and possibly medium sized fields is fair to good. 


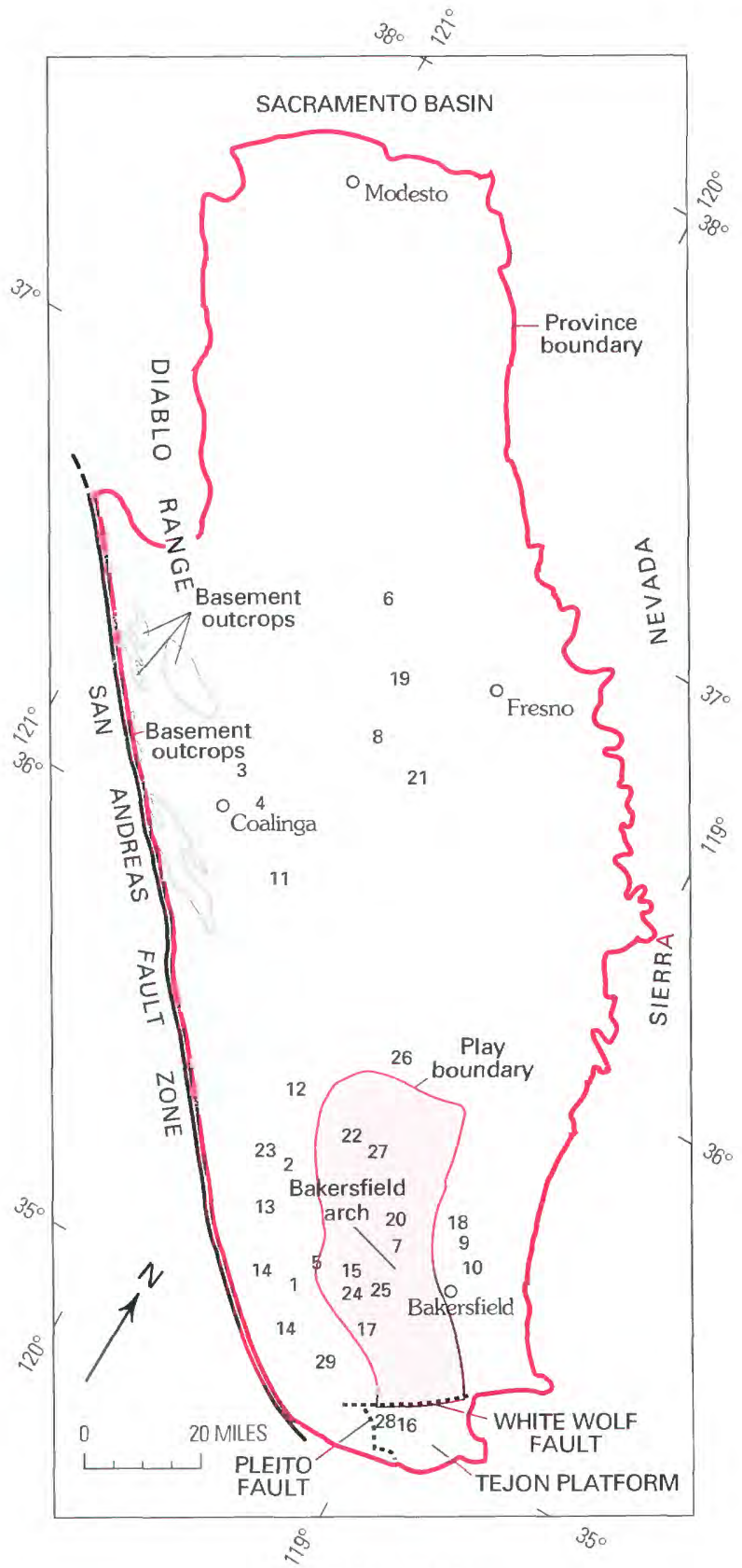

\section{EXPLANATION}

Selected oil and gas fields

$\begin{aligned} 1 & \text { Buena Vista } \\ 2 & \text { Cal Canal } \\ 3 & \text { Coalinga } \\ 4 & \text { Coalinga East Extension } \\ 5 & \text { Elk Hills } \\ 6 & \text { Gill Ranch } \\ 7 & \text { Greeley } \\ 8 & \text { Helm } \\ 9 & \text { Kern Front } \\ 10 & \text { Kern River } \\ 11 & \text { Kettleman North Dome } \\ 12 & \text { Lost Hills } \\ 13 & \text { McKittrick } \\ 14 & \text { Midway-Sunset } \\ 15 & \text { North Coles Levee }\end{aligned}$

16 North Tejon

17 Paloma

18 Poso Creek

19 Raisin City

20 Rio Bravo

21 Riverdale

22 Semitropic

23 South Belridge

24 South Coles Levee

25 Ten Section

26 Trico

27 Wasco

28 Wheeler Ridge

29 Yowlumne
Figure 46. Map of East Pre-Pliocene play (074-060).

\section{OIL AND GAS PLAY DATA}

PLAY EAST PRE-PLIOCENE

PROVINCE SAN JOAQUIN BASIN

CODE 02-074-060 Play attributes

Probability of attribute being favorable or present

Hydrocarbon source (S)

Timing ( $T$ )

Migration (M)

Potential reservoir-rock facies (R)

Marginal play probability (MP)

( $(\mathrm{S} \times \mathrm{T} \times \mathrm{M} \times \mathrm{R}=\mathrm{M})$

Accumulation attribute, conditional on favorable play attributes

Minimum size assessed: oil, $1 \times 10^{6} \mathrm{BBL}$; gas, $6 \times 10^{9} \mathrm{CFG}$

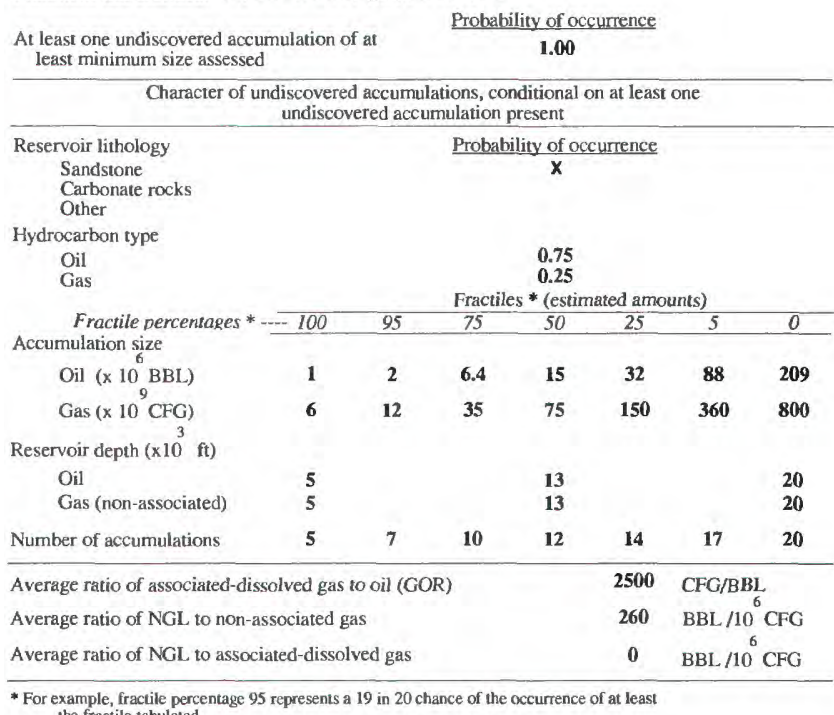

example, fractile percentage 95 represents a 19 in 20 chance of the occurrence of at leas
the fractile tabulated. 


\section{WEST PRE-UPPER MIOCENE PLAY (070)}

The play consists of oil and gas fields in a variety of trap types that produce from sandstone reservoirs ranging from Upper Cretaceous to middle Miocene in age in the southwest part of the late Mesozoic forearc basin and the western part of the Tertiary basin. The play area covers about $5,380 \mathrm{mi}^{2}$ and is bordered on the west by the San Andreas fault zone (fig. 47). Rocks in the play are the most complex, structurally and stratigraphically, in the San Joaquin basin. Most important formations are time-transgressive, possess complex lithofacies that reflect active tectonic control of sedimentation, and have undergone several episodes of deformation. Complexity of lithofacies and degree of deformation increase from the east to the western and southern margins of the play.

Upper Cretaceous and lower Paleocene, largely turbidite, sandstone units occur north of an east-west line through the Bakersfield arch; their reservoir quality is generally poor. Very minor amounts of oil and gas have been found in uplifted parts of the Panoche Group and Moreno Formation along the west margin. Upper Paleocene and lower Eocene rocks consist of turbidite sandstone facies of the Lodo Formation. The Gatchell sand of local usage at Kettleman North Dome field is a prominent oil reservoir in the Coalinga area; its thickness is as much as $620 \mathrm{ft}$, porosity is 9-22 percent, and productive depths are at 7,400 to $11,700 \mathrm{ft}$. Thin sandstone reservoirs resulting from the regressive-transgressive cycle at the end of the early Eocene produce mostly minor amounts of oil in widely separated fields along the western play area (for example, Domengine Sandstone and its lateral equivalents).

Rocks representing the most widespread and long-lasting marine transgressive cycle of the Tertiary belong to the middle Eocene part of the Kreyenhagen Shale, in particular its major deep-sea fan, the Point of Rocks Sandstone Member, and the overlying upper Eocene Tumey and Wagonwheel Formations (Oceanic sand of local usage). Sandstone reservoirs also occur in the middle Eocene rocks of the Tejon Formation and the upper Eocene San Emigdio Formation along the southern margin of the play. Fractured shale of the Kreyenhagen and Wagonwheel (Tumey) Formations has produced some oil, and must also be considered as a potential oil reservoir. Reservoirs in the Point of Rocks Sandstone Member and the Oceanic sand are productive in 15 fields. They range in thickness from about 30 to $400 \mathrm{ft}$, have porosities of about 10 to 35 percent, and occur at depths of 600 to $11,000 \mathrm{ft}$.

Rocks of the Oligocene to middle Miocene Temblor Formation embrace a variety of lithofacies that range from nonmarine to deep-marine, and are present over most of the play area. Recognized Temblor reservoirs (for example, Burbank, Carneros, Phacoides sands of local usage) range in thickness from about 5 to $1,500 \mathrm{ft}$; their porosities are 9-35 percent, and they occur at depths from 400 to $13,320 \mathrm{ft}$.

Organic-rich, oil-prone shale of the Kreyenhagen Shale and Monterey Formation, which probably began oil generation in middle and late Miocene time, is the source rock for most of the oil and gas in the play. Abundant faults, fracture zones, and other permeable routes aided migration to traps which formed during repeated deformational episodes beginning probably as early as late Paleogene time. Discovered traps include structural, stratigraphic, combination, and diagenetic types.

Principal oil and gas fields (with year of discovery and (or) years of production, and cumulative production plus estimated reserves through 1984) are Coalinga (1887-1900, 785 MMBO, 215 BCFG), Coalinga East Extension (1938, 506 MMBO, 357 BCFG), and Kettleman North Dome (1928, 457 MMBO, 2.70 TCFG). Cumulative production plus estimated reserves of oil and gas through 1984 from the 22 fields in the play are $2.58 \mathrm{BBO}$ and 5.21 TCFG, respectively.

Although the play is mature, future potential for undiscovered oil and gas fields of medium size is estimated to be very good. 


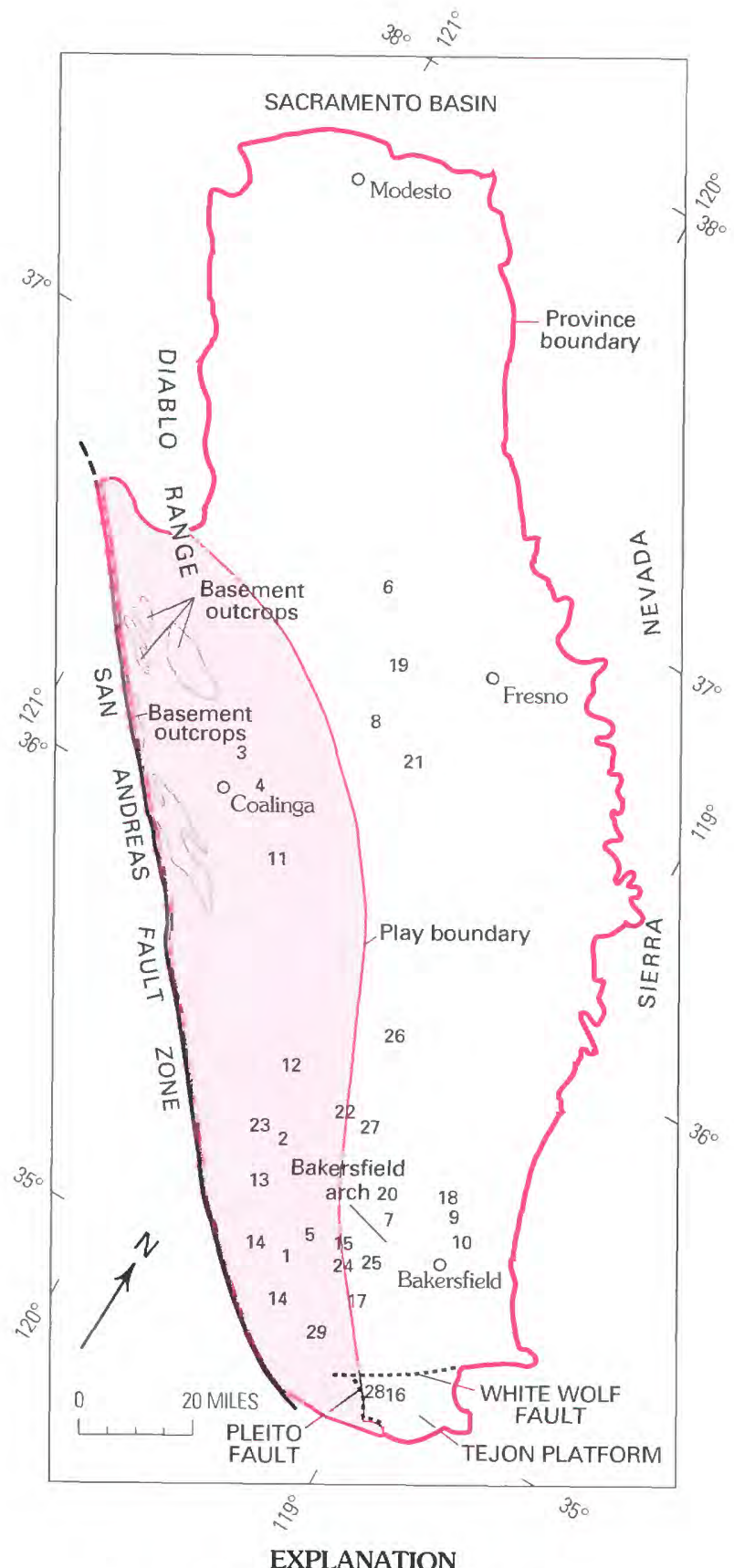

\section{EXPLANATION}

$\begin{aligned} 1 & \text { Buena Vista } \\ 2 & \text { Cal Canal } \\ 3 & \text { Coalinga } \\ 4 & \text { Coalinga East Extension } \\ 5 & \text { Elk Hills } \\ 6 & \text { Gill Ranch } \\ 7 & \text { Greeley } \\ 8 & \text { Helm } \\ 9 & \text { Kern Front } \\ 10 & \text { Kern River } \\ 11 & \text { Kettleman North Dome } \\ 12 & \text { Lost Hills } \\ 13 & \text { McKittrick } \\ 14 & \text { Midway-Sunset } \\ 15 & \text { North Coles Levee }\end{aligned}$

16 North Tejon

17 Paloma

18 Poso Creek

19 Raisin City

20 Rio Bravo

21 Riverdale

22 Semitropic

23 South Belridge

24 South Coles Levee

25 Ten Section

26 Trico

27 Wasco

28 Wheeler Ridge

29 Yowlumne
Figure 47. Map of West Pre-Upper Miocene play (074-070).
OIL AND GAS PLAY DATA

PLAY WEST PRE-UPPER MIOCENE

PROVINCE SAN JOAOUIN BASIN

CODE 02-074-070

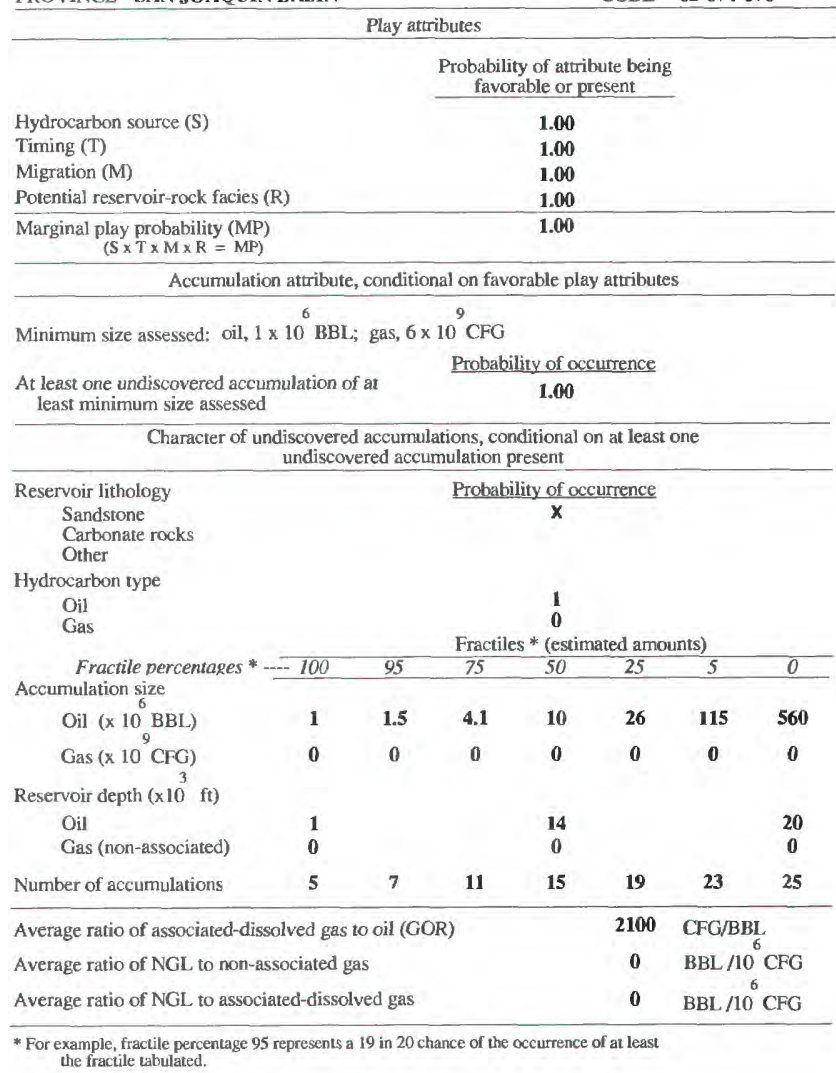




\section{NORTHERN PRE-PLIOCENE PLAY (080)}

The play consists of oil and nonassociated gas fields in faulted anticlinal and stratigraphic traps that produce mainly from Upper Cretaceous and lower Paleogene sandstone reservoirs. These rocks fill (1) a part of the late Mesozoic forearc basin that is located in the northern San Joaquin basin, and (2) the adjoining (and partly superimposed), relatively stable northeast limb of the Tertiary basin to the south where Oligocene and younger rocks are mostly nonmarine (fig. 48). The play covers about 7,820 $\mathrm{mi}^{2}$, and its southwest boundary corresponds approximately to the average position of the marine shelf edge of the Sierran block during Miocene time, as defined by $300-\mathrm{ft}$ paleoisobaths. The northern part of this southwest boundary corresponds approximately to the eastern limit of Neogene compressional deformation and the northeastern limit of the marine Oligocene and Miocene Temblor Formation of the West Pre-Upper Miocene play (070).

Upper Cretaceous and lower Paleogene reservoir rocks in the play consist principally of (1) deep-sea fan deposits and associated lithofacies on the west side and (2) shallow marine to deltaic deposits on the east side. The lower Paleogene part of the sedimentary sequence consists mostly of westward- and southwestward-prograding slope, shelf, and deltaic facies. Productive reservoirs in the upper part of the Panoche Group, and in the Moreno, Tesla, Laguna Seca, and Lodo Formations include a number of locally named reservoirs (for example, Forbes, Lathrop, Tracy, Starkey, and Panoche sands). These reservoirs occur at depths from 2,600 to $9,200 \mathrm{ft}$, generally are from 6 to $50 \mathrm{ft}$ thick, and exhibit porosities between about 23 and 35 percent.

Organic-rich, oil-prone shales of the Eocene Kreyenhagen Shale, and Miocene Monterey Formation from the deeper Tertiary basin to the south and southwest, are the probable source rocks for the small quantities of oil discovered in the southern part of the play. The nonassociated gas fields in the northern part of the play are believed to have their source in known gas-prone Cretaceous shales of the Delta depocenter, located to the north in the Sacramento Basin province. However, it seems likely that more local source rocks exist for at least some discovered nonassociated gas reservoirs. Shale units of the Moreno Formation near Coalinga are reported to be favorable oil source rocks, but their importance in the play remains unknown.

Known traps include gentle anticlines with stratigraphic variations and minor faulting. Anticipated traps range from simple truncated pinchouts in shelf facies to complex stratigraphic traps in basinal or slope facies, such as basin-margin wedging of turbidite sandstones.

Principal oil and gas fields (with year of discovery and cumulative production plus estimated reserves through 1984) are Raisin City (1941, 41 MMBO, 26 BCFG), Helm (1941, 31 MMBO, 74 BCFG), Riverdale (1941, 21 MMBO, 28 BCFG), and Gill Ranch (1943, 65 BCFG) fields. Cumulative production plus estimated reserves of oil and gas through 1984 from the eight fields in this play are $0.13 \mathrm{BBO}$ and $0.13 \mathrm{TCFG}$, respectively.

The play contains abundant sandstone and is of large areal extent, but only nine small oil fields, including two abandoned, and five nonassociated gas fields have been discovered through 1986. Limiting factors to future potential include the questionable existence of abundant gas- or oil-prone source rocks in much of the play area, and probable long migration distances. Large volumes of Cretaceous rocks, especially along the west side of the play area, might contain deep gas reservoirs, but the factors of abundant nearby source rocks, reasonable migration distances, and good-reservoir-quality sandstone remain unproven. Undiscovered field sizes are estimated to be small, and overall future potential is low. 


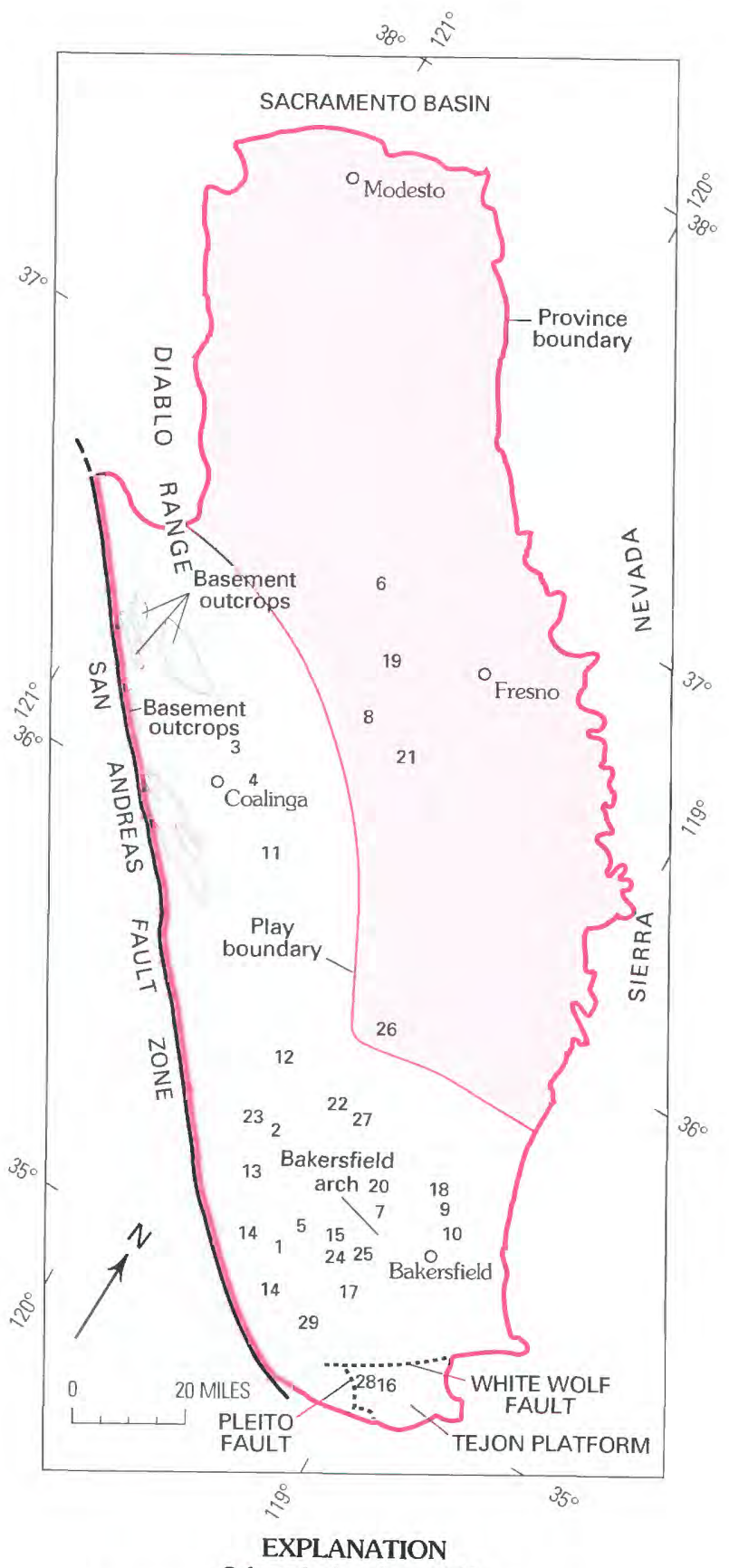

Selected oil and gas fields
16 North Tejon

17 Paloma

18 Poso Creek

19 Raisin City

20 Rio Bravo

21 Riverdale

22 Semitropic

23 South Belridge

24 South Coles Levee

25 Ten Section

26 Trico

27 Wasco

28 Wheeler Ridge

29 Yowlumne
Figure 48. Map of Northern Pre-Pliocene play (074-080).

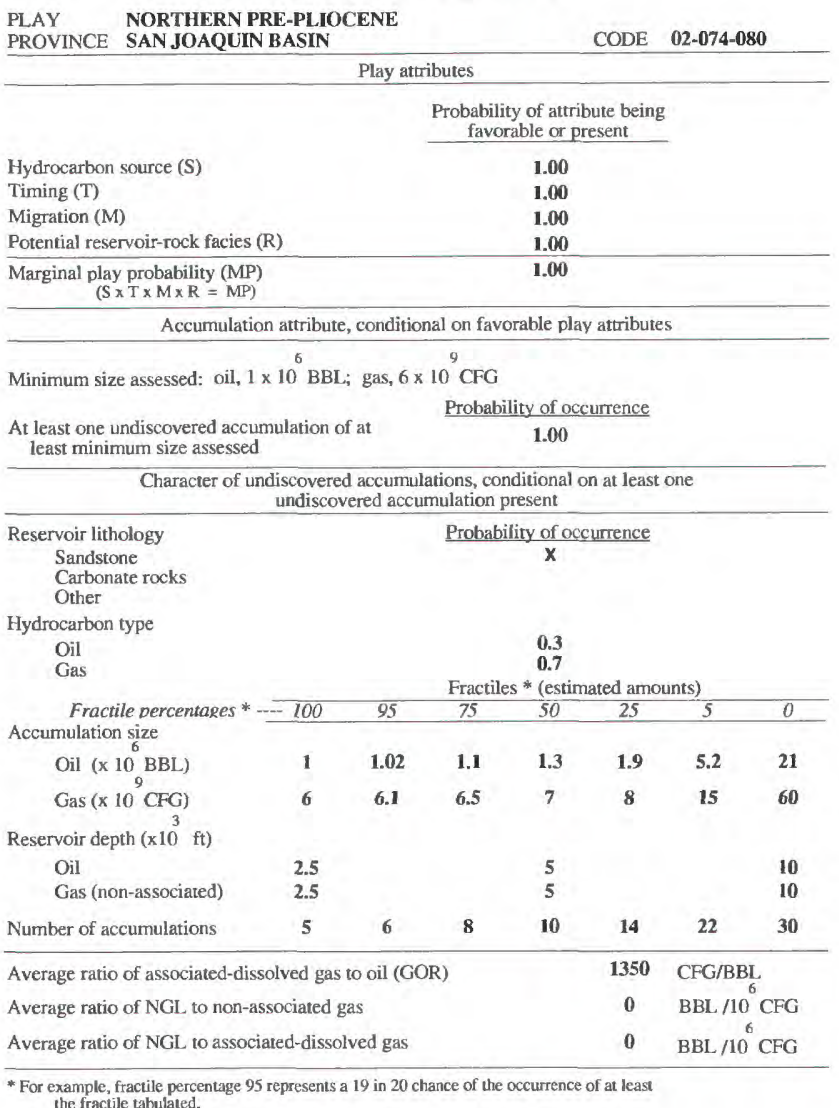




\title{
LOS ANGELES BASIN PROVINCE (075)
}

\author{
By Larry A. Beyer

\section{INTRODUCTION}

The Los Angeles basin, located in coastal southern California, is primarily a Neogene tectonic feature that developed as a result of Cretaceous and early Paleogene subduction, Paleogene terrane accretion, and middle Miocene to present rifting and block rotation. The triangle-shaped Los Angeles Basin province includes a northwest-trending central syncline about $45 \mathrm{mi}$ long and $20 \mathrm{mi}$ wide that contains at least $24,000 \mathrm{ft}$ of upper middle Miocene and younger marine clastic rocks overlying older Cenozoic sedimentary rocks (fig. 49).

Major oil fields, with estimated recoverable oil and gas at the end of 1986, are Wilmington (2.788 BBO, 1.193 TCFG), Huntington Beach (1.138 BBO, 861 BCFG), Long Beach (927 MMBO, 1.088 TCFG), and Santa Fe Springs (634 MMBO, 839 BCFG). Cumulative production of oil and gas through 1986 from 69 province fields was $7.790 \mathrm{BBO}$ and 7.270 TCFG. The largest fields were discovered prior to 1940 . The last major discoveries (Beverly Hills, Cheviot Hills, and Las Cienegas, 1954-1960) have been followed by only minor field discoveries. Although exploration has been hampered by urbanization for more than 20 years, production of oil has continued to increase due to reservoir extensions, new pool discoveries, and improved recovery techniques in existing large fields. Three plays were individually assessed in the province: Northwest Shelf, North Flank, and Central and Northeast. 
REGION 1, ALASKA; REGION 2, PACIFIC COAST

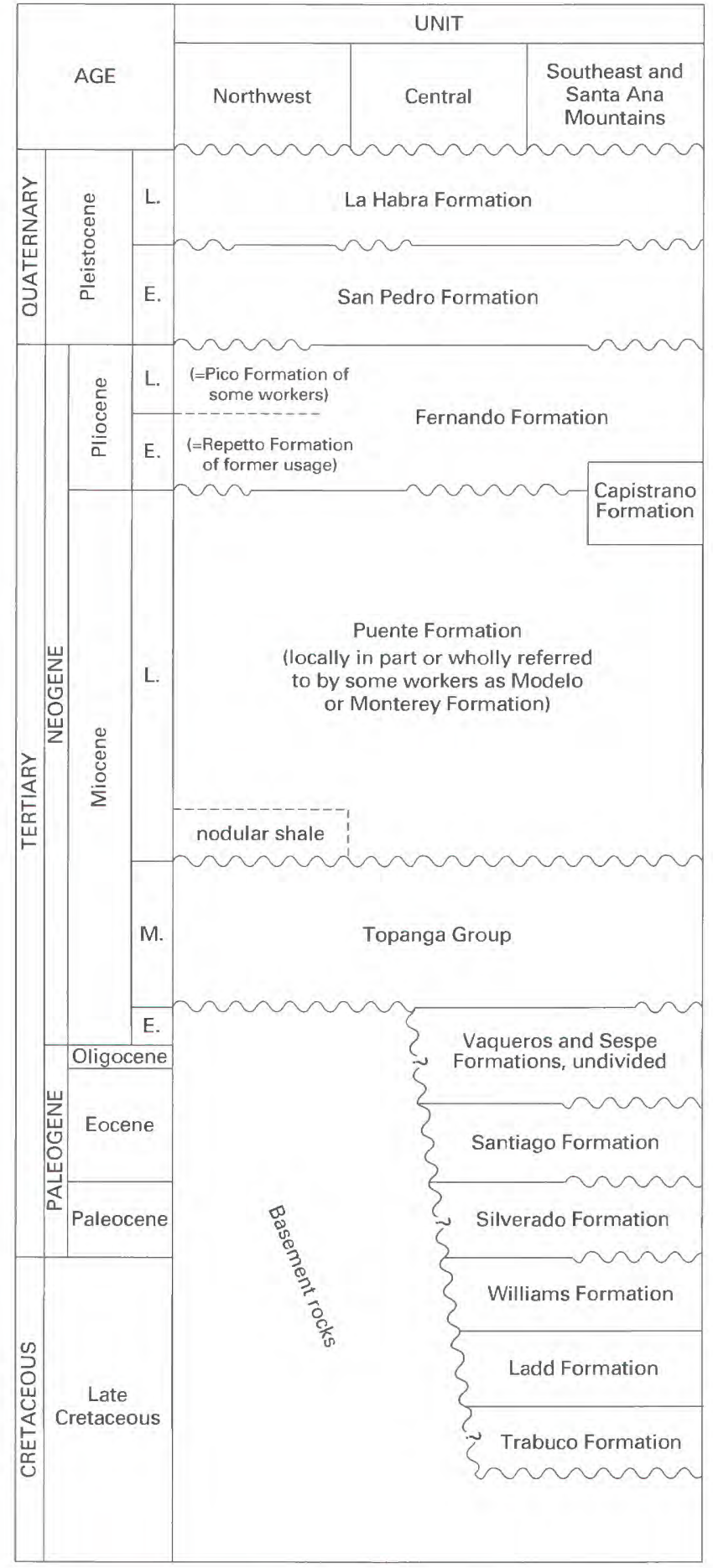

Figure 49. Generalized stratigraphic column, Los Angeles Basin province (075). Contact dashed where uncertain or informal. Wavy line, unconformity; queried where extent uncertain. 


\section{NORTHWEST SHELF PLAY (020)}

The Northwest Shelf play consists of oil and associated gas fields that produce from weathered basement rocks and marine sandstone reservoirs of Miocene and Pliocene age in structural traps. The play covers about $75 \mathrm{mi}^{2}$ and includes rocks in the area southwest of the northern part of the NewportInglewood zone of deformation, northwest of the Palos Verdes Hills, and south of the western boundary of the North Flank play (030), including adjacent State waters (fig. 50). Reservoir rocks are less deformed here than elsewhere in the Los Angeles basin. The prominent structural feature in the play is a northwesttrending ridge in the schist basement along the northwest shelf of the Los Angeles basin.

Oil-bearing reservoirs occur in fractured and weathered schist basement, schist conglomerate overlying the basement, and, to a minor extent, in overlying upper Miocene marine sandstones of the Puente Formation (which some workers locally call (in part or wholly) the Modelo or Monterey Formation) and in lower Pliocene marine sandstones of the Fernando Formation (equivalent to the Repetto Formation of former usage). The few marine sandstone units in the play represent very distal facies of turbidite sequences derived, beginning in latest Miocene time, from sediment source areas located to the north and northeast across the in-filling central syncline. Discovered reservoirs occur at depths of about 1,500 to $9,000 \mathrm{ft}$; thickness ranges from 14 to $300 \mathrm{ft}$ and porosity is generally good. Seals are low-permeability shale or claystone and tightly cemented sandstone.

The organic-rich, oil-prone shale of the basal unit (the so-called nodular shale) of the Puente Formation, locally extensive, is believed to be the principal source rock for underlying reservoirs in fractured schist, in schist conglomerate, and in the overlying sandstone of the Puente and lower Fernando (Repetto) Formations. Oil presumably migrated from onlapping upper Miocene strata into the older schist basement and conglomerate in places where the conglomerate is structurally higher. Generation and migration of oil coincident with trap formation are well established in the play. Known and anticipated traps include faulted domes and anticlines that appear to involve basement folding, fractured and weathered basement rocks, lenticular sands, and overlapped sandstone lenses.

Principal fields in the play (with year of discovery and cumulative production plus estimated reserves through 1986) are Playa del Rey (1929, 63 MMBO, 62 $\mathrm{BCFG})$ and $\mathrm{El}$ Segundo $(1935,14$ MMBO, 35 BCFG). Cumulative production plus estimated reserves of oil and gas through 1986 from the seven fields in the play are $89 \mathrm{MMBO}$ and $71 \mathrm{BCFG}$, respectively.

The onshore part of the play is well explored and the future potential for discovery of small fields is poor and affected by urbanization. Numerous oil and (or) gas seeps are present in the State waters part of the play, and the future potential is fair to good for the discovery of small to medium-sized fields in these waters. A major limiting factor, however, is a moratorium against exploratory drilling in State waters, which has been in effect since the late 1960's.

OIL AND GAS PLAY DATA

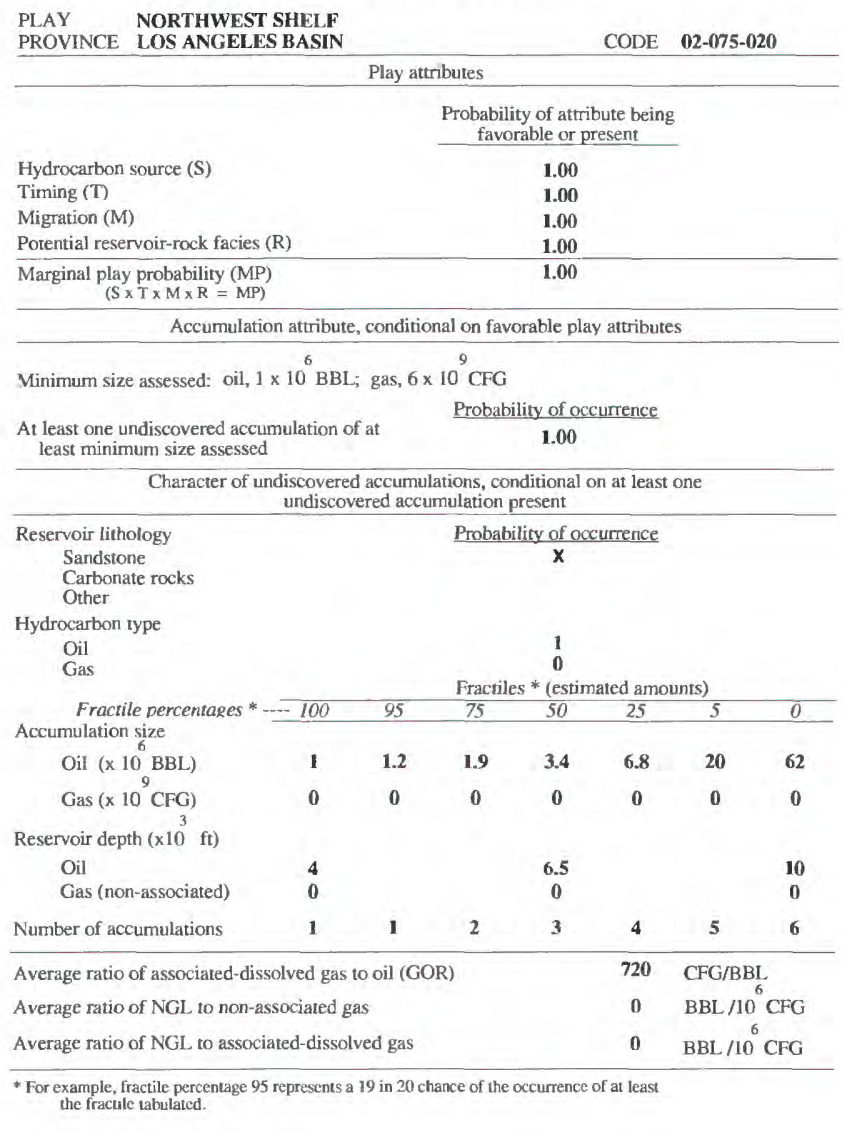




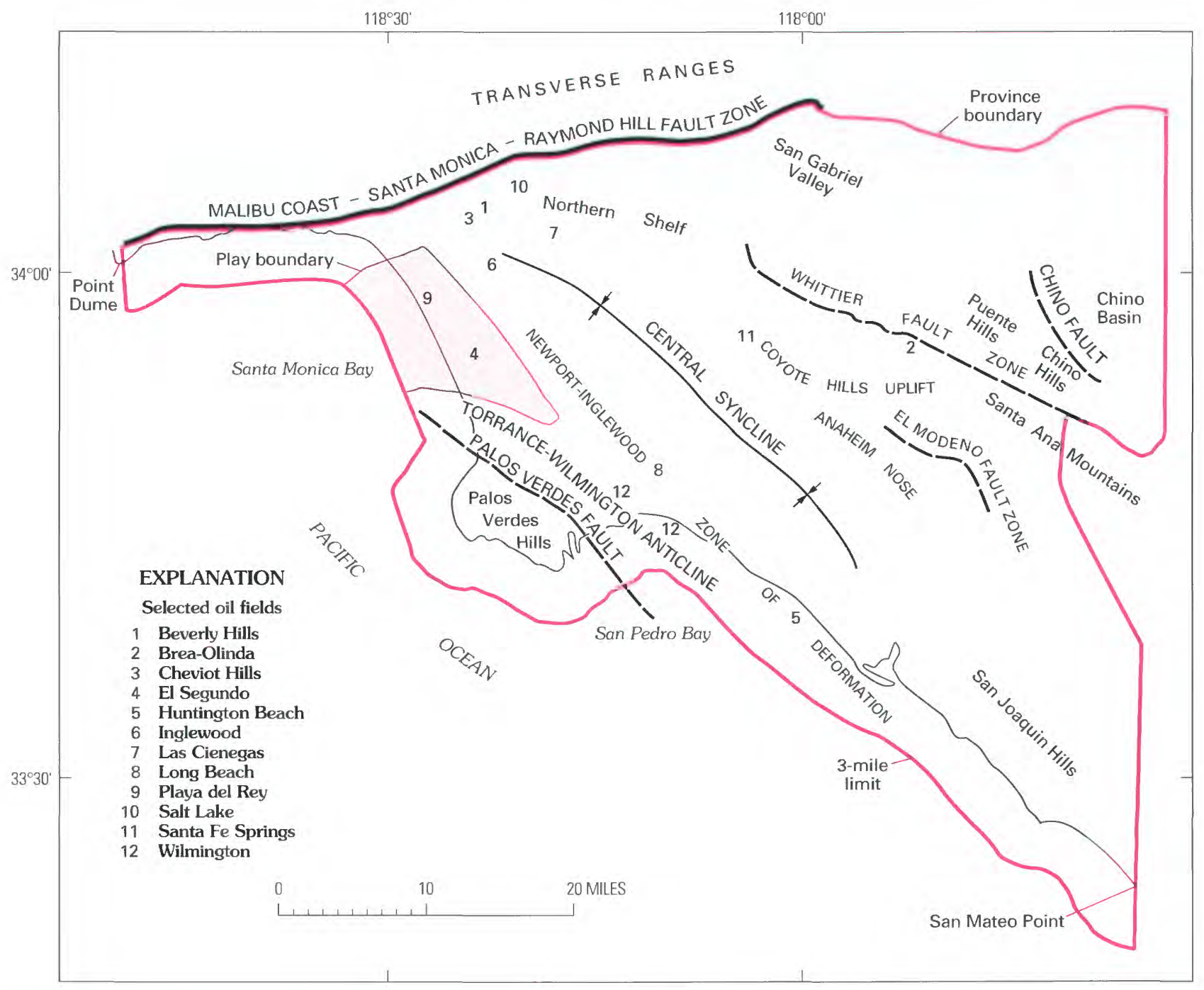

Figure 50. Map of Northwest Shelf play (075-020). 


\section{NORTH FLANK PLAY (030)}

The play consists of oil and gas fields that produce from sandstone reservoirs of Miocene and Pliocene age associated with anticlinal structures related to the Malibu Coast-Santa Monica-Raymond Hill fault trend. The play covers an area of about $180 \mathrm{mi}^{2}$ along the extreme northwestern flank of Los Angeles basin (fig. 51). The southern play boundary is drawn approximately where the axis of the central syncline turns westward. The eastern and southeastern boundary is drawn to include the western part of the northern shelf, but excludes most of the San Gabriel Valley. The play also includes adjacent State waters to the west that are bounded on the north by the Malibu Coast fault, on the south by the 3mile limit of State waters, and arbitrarily extended westward to Point Dume (fig. 51).

Reservoirs are upper Miocene sandstone units of the Puente Formation (locally, in part or wholly referred to by some workers as the Modelo or Monterey Formation) and the lower Pliocene Fernando Formation (equivalent to Repetto of former usage) (fig. 49). A small amount of gas is produced from sandstone of the upper Pliocene Fernando (equivalent to Pico Formation of some workers) in one field. In some cases, organic-rich shale encapsulates the channel-like turbidite sandstone reservoirs of the Puente Formation that were derived from sources north of the present-day Santa Monica Mountains. Lower Pliocene Fernando (Repetto) sandstone reservoirs apparently are distal turbidite facies derived from submarine canyons that were located along the northeastern margin of the Los Angeles basin. Discovered reservoirs occur at depths from about 900 to $10,800 \mathrm{ft}$; their thickness ranges from about 30 to $2,000 \mathrm{ft}$ and porosity from 15 to 35 percent. Seals are low-permeability shale or claystone and tightly cemented sandstone. Reservoirs have not been found in the middle Miocene Topanga Group or older rocks.

The organic-rich, oil-prone basal unit (so-called nodular shale) of the Puente Formation is believed to be the source of oil in the northwestern part of the Los Angeles basin, although shale of the Puente and lower part of the Fernando Formations, located in deeper parts of the basin and more diluted by terrigenous debris, probably also contributed. Generation and migration of oil coincident with trap formation are well established in the play.

Known and anticipated traps include west- and northwest-trending anticlines, faulted anticlines and homoclines, sandstone pinchouts on homoclines, and lenticular sandstones. Traps near the Santa Monica fault zone, occurring in the footwall (south) block, are complex structures partly involving overturned folds. Other known traps on the western part of the northern shelf are related to generally east-west-trending reverse faults that dip steeply north.

Principal fields (with year of discovery and (or) years of production, and cumulative production plus estimated reserves through 1986) are Beverly Hills (1900-1967, 164 MMBO, 215 BCFG), Las Cienegas (1961, 65 MMBO, 55 BCFG), and Salt Lake (1902-1961, 54 MMBO, 212 BCFG). Cumulative production plus estimated reserves of oil and gas through 1986 from 12 fields in the play are 397 MMBO and 691 BCFG, respectively.

The eastern part of the play is moderately well explored, but down-dip areas to the south toward the central syncline remain largely untested. The western part of the onshore play area, where at least one significant potential prospect has remained undrilled for 20 years, is somewhat less well explored because of the restraints of urbanization. Numerous oil and (or) gas seeps are present in the western part of the play in State waters, but a drilling moratorium has been in effect there since the late 1960's, and few exploration wells have been drilled. Future potential for discovery of several small to moderate-sized fields is fair to good, but urbanization and drilling moratoriums have largely curtailed exploration for several decades.

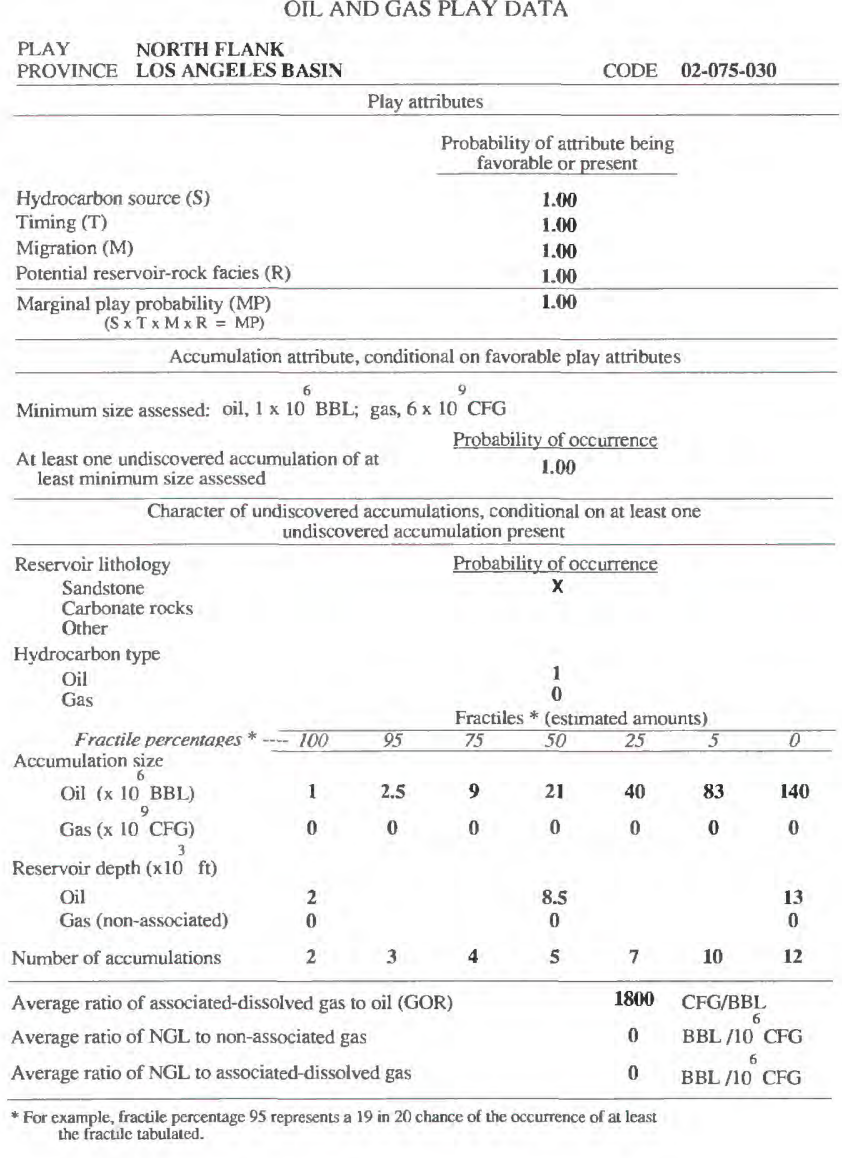


REGION 1, ALASKA; REGION 2, PACIFIC COAST

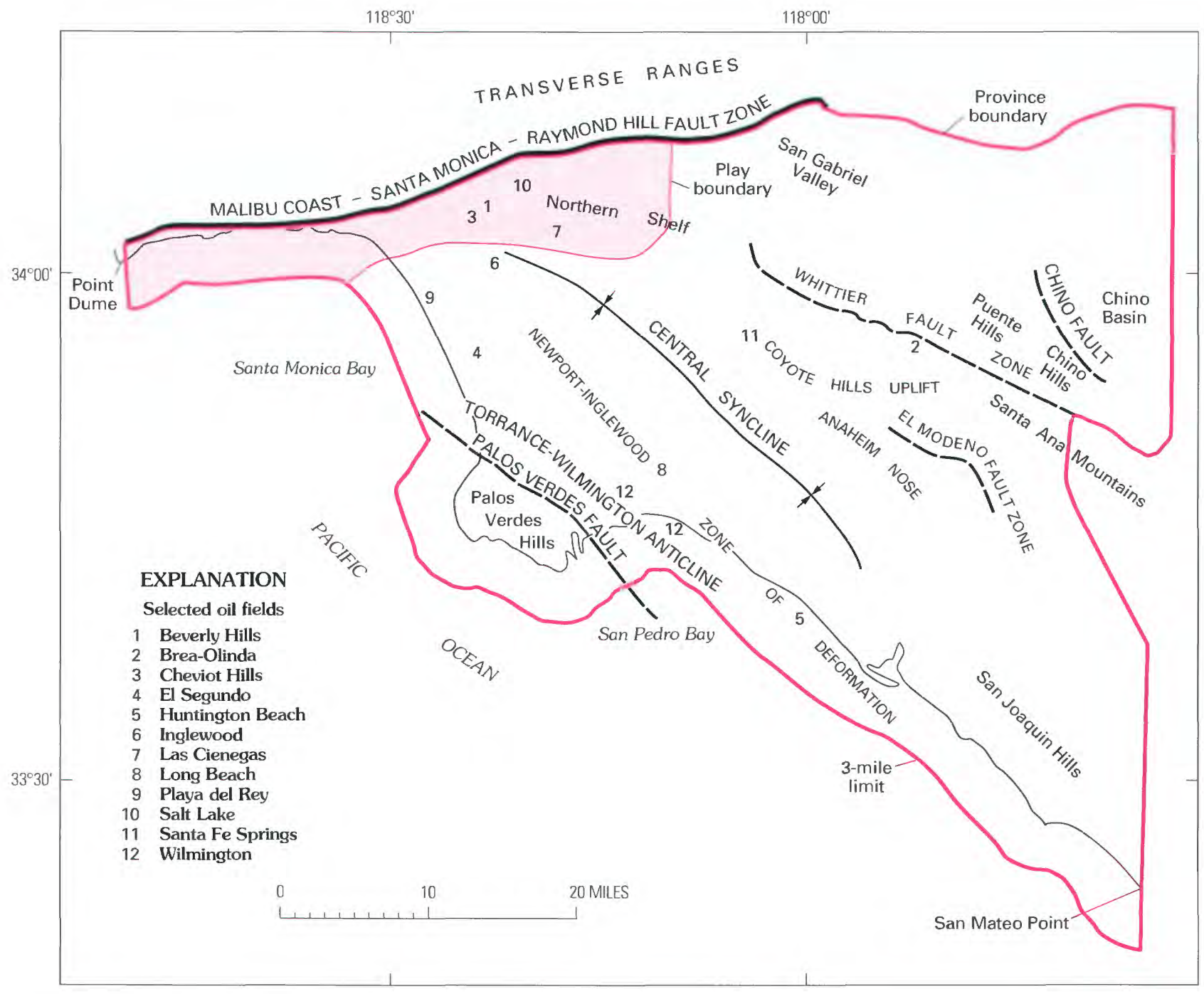

Figure 51. Map of North Flank play (075-030). 


\section{CENTRAL AND NORTHEAST PLAY (040)}

The play, which covers about $1,720 \mathrm{mi}^{2}$, contains oil and gas fields in sandstone reservoirs of Miocene and Pliocene age that produce from faulted anticlines on the upper flanks and faulted margins of the central syncline, and adjacent areas (fig. 52). Discovered oil fields southwest of the central syncline lie along the northwest-trending Newport-Inglewood zone of deformation, and along the adjacent, subparallel Torrance-Wilmington anticlinal trend. Northeast of the central syncline, oil fields are on (1) the northwest-plunging Anaheim nose, (2) the western extension(?) of the El Modeno fault zone, (3) the west- to northwest-trending Coyote Hills uplift and its southeastern flank, (4) the Whittier fault zone, (5) the Chino fault and basin, (6) the Puente Hills north of the Whittier fault zone, and (7) the eastern part of the northern shelf.

Reservoirs southwest of the central syncline are mostly sandstone units of the upper Miocene Puente Formation (locally, in part or wholly referred to by some workers as the Modelo or Monterey Formation), and lower Pliocene rocks of the Fernando Formation (equivalent to Repetto Formation of former usage) that were derived from source areas to the north, northeast, and east. Additional production is obtained from sandstone of the middle Miocene Topanga Group, and from fractured schist basement rocks and associated overlying basal conglomerate units. Reservoirs northeast of the central syncline occur in varied marine facies ranging from distal turbidite sandstone to proximal conglomeratic sandstone of the Puente and lower part of the Fernando (Repetto) Formations. Discovered reservoirs occur at depths from 900 to $11,900 \mathrm{ft}$; their thickness ranges from 15 to $1,200 \mathrm{ft}$ and porosity from 15 to 35 percent. Seals are low-permeability shale or claystone and tightly cemented sandstone.

Organic-rich, oil-prone shale of the Puente Formation and possibly some shale in the lower part of the Fernando Formation (Repetto) are believed to be the source of oil in the play. Oil has migrated principally from the central syncline, although organic-rich shale in flank and shelf areas may also have contributed. Generation and migration of oil occurred simultaneously with trap formation, beginning as early as late Miocene time in some parts of the basin, and continue to the present. Known and anticipated traps are predominantly faulted anticlines with a lesser number of faulted noses and homoclines, domes, and still fewer stratigraphic traps.

Principal fields (with year of discovery and cumulative production plus estimated reserves through 1986) are Wilmington (1932, 2.788 BBO, 1.192 TCFG), Huntington Beach (1920, 1.138 BBO, 861 BCFG), Long Beach (1921, 927 MMBO, 1.088 TCFG), Santa Fe Springs (1919, 622 MMBO, 836 BCFG), Brea-Olinda (1880, 438 MMBO, $482 \mathrm{BCFG})$, and Inglewood (1924, $400 \mathrm{MMBO}$, 285 BCFG). Cumulative production plus estimated reserves of oil and gas through 1986 from the 47 fields in the play are 7.304 BBO and 6.508 TCFG, respectively.

Upper Miocene and younger rocks have been thoroughly explored in much of the play except for possible down-dip traps on the deeper flanks and at the east end of the central syncline. Future potential is fair to good for small to medium-sized fields in down-dip areas and in pre-upper Miocene rocks on the Anaheim nose, in offshore extensions of the Palos Verdes fault zone and its associated structures in San Pedro and Santa Monica Bays, and in the eastern part of the northern shelf. Areas north of the Whittier fault zone have not been thoroughly drilled, and some potential exists for the discovery of small fields. The southeastern part of the play is not well explored, but its potential appears less favorable because of its distance from source rocks of the central syncline, its lack of abundant sandstone of late Miocene and early Pliocene age, and the lower porosity of pre-upper Miocene rocks. Urbanization and drilling moratoriums in State waters have restricted or curtailed exploration for several decades.

OIL AND GAS PLAY DATA

PLAY CENTRAL AND NORTHEAST

PROVINCE LOS ANGELES BASIN

Play attributes

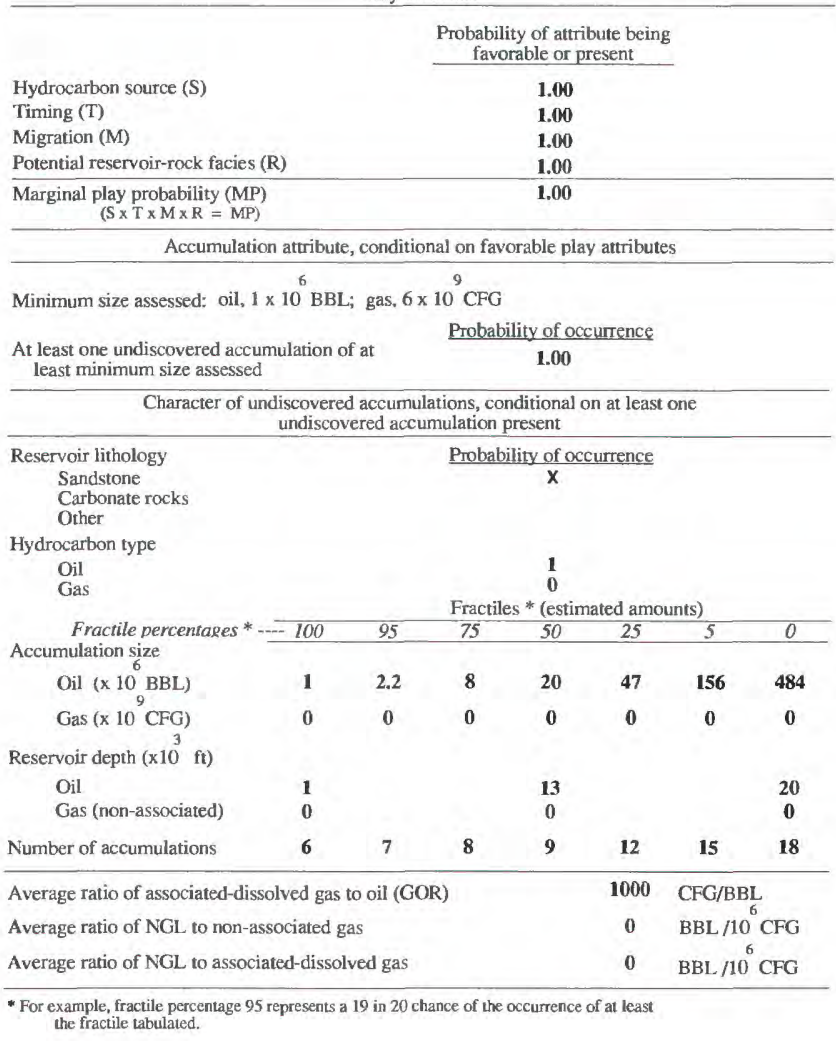


REGION 1, ALASKA; REGION 2, PACIFIC COAST

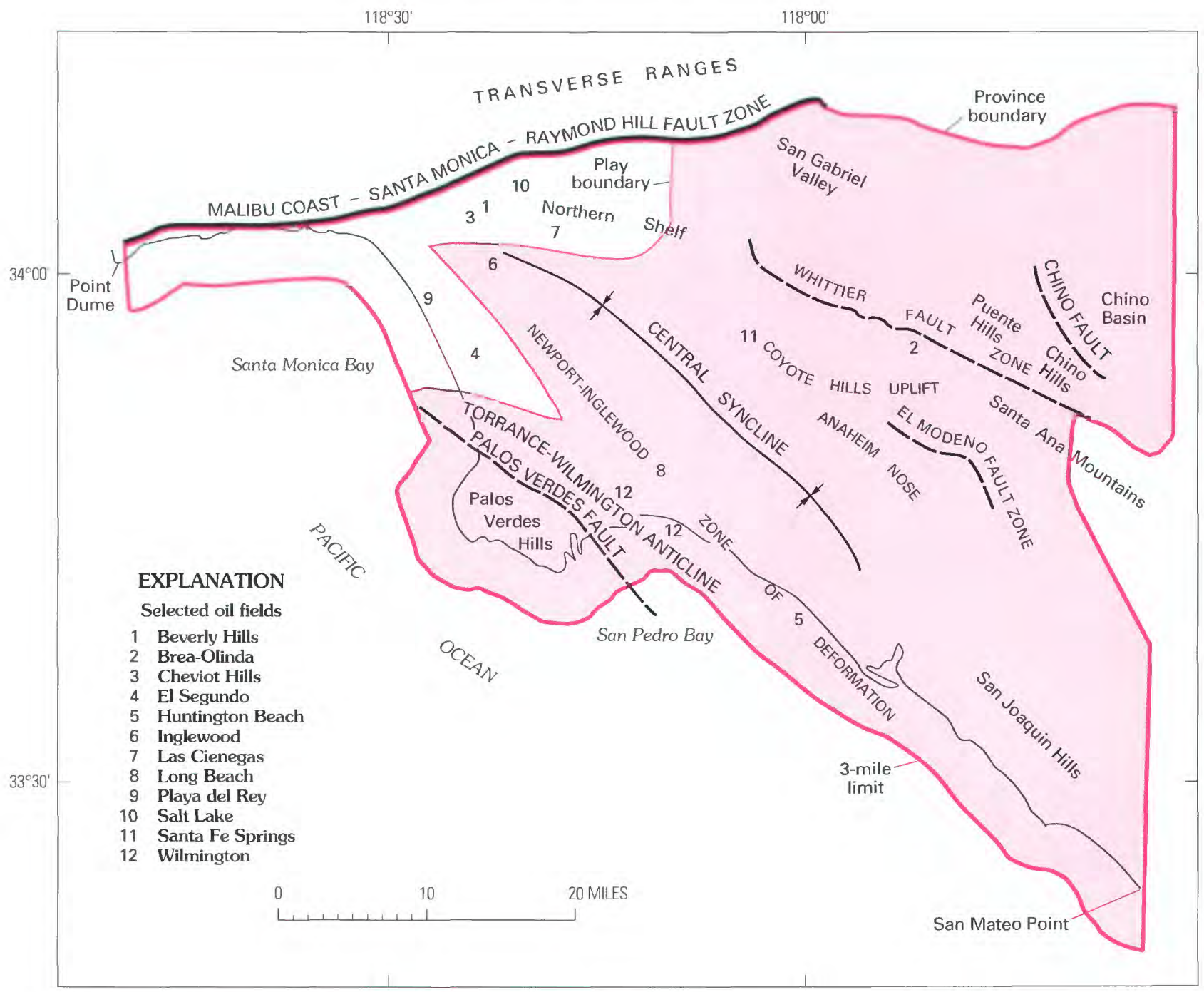

Figure 52. Map of Central and Northeast play (075-040). 


\title{
VENTURA BASIN PROVINCE (076)
}

\author{
By Margaret A. Keller
}

\section{INTRODUCTION}

The Ventura Basin province, located in southern California, consists of the area both north and east of the Santa Barbara Channel, bounded approximately on the north by the Santa Ynez and Big Pine faults, on the east by the San Gabriel fault, on the south by the Malibu Coast-Santa Monica fault zone and the 3-mile limit of State waters of the Santa Barbara-Ventura coastal area, and on the west by the 3-mile limit of State waters. The province is 7 to $40 \mathrm{mi}$ wide and as much as $130 \mathrm{mi}$ long. It covers approximately $2,630 \mathrm{mi}^{2}$, including State waters.

Most crude oils in the province are chemically similar; most traps are anticlinal, but modified to some degree by faults, and most of the reservoirs are sandstone. Reservoirs range in age from Late Cretaceous to Pleistocene (fig. 53), and reservoir age closely corresponds to tectonic geographic area. The first field discovered in the Ventura basin was Santa Paula in 1861, northeast of Ventura. However, the major production in the province is located on the east-west Rincon anticlinal trend. This trend contains three onshore giant (>100 MMBO) oil fields (Ventura Avenue, Rincon, and San Miguelito). Sixty-five of the 95 oil and gas fields discovered in the province have ultimate recoveries greater than $1 \mathrm{MMBO}$ or $6 \mathrm{BCFG}$ each. Cumulative production through 1986 is approximately $2.14 \mathrm{BBO}$ and 4.42 TCFG; approximately $85-90$ percent of this production is from the Neogene sequence. Two plays were individually assessed in the province: Neogene and Paleogene. 
REGION 1, ALASKA; REGION 2, PACIFIC COAST

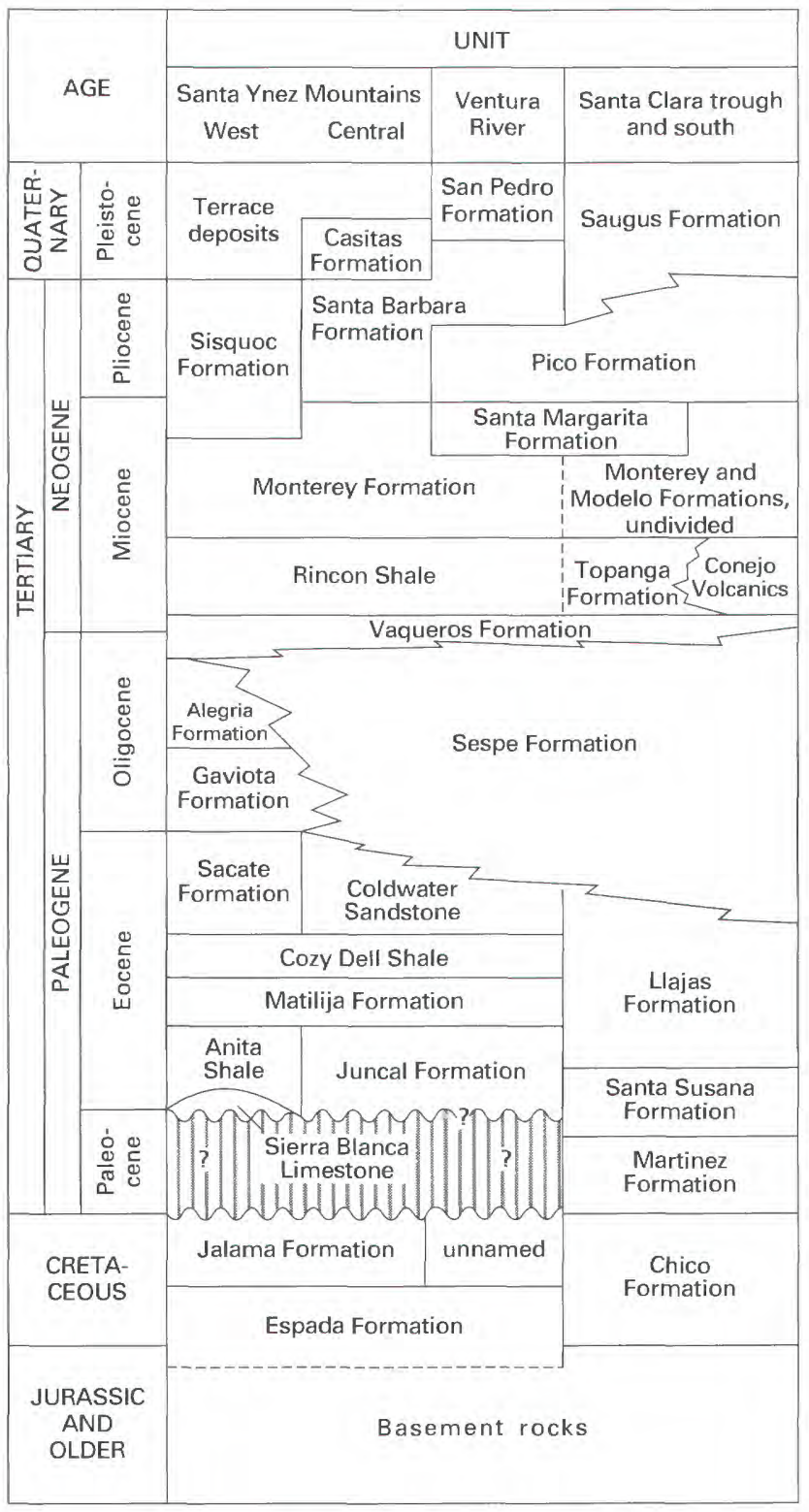

Figure 53. Generalized stratigraphic column, Ventura Basin province (076). Contact dashed where uncertain. Vertical line pattern, hiatus; queried where lateral extent uncertain. Wavy line, unconformity; queried where position uncertain. 


\section{NEOGENE PLAY (020)}

The Neogene play is characterized by oil and associated gas accumulations in structural, stratigraphic, or combination traps in clastic reservoirs of early Miocene to Pleistocene age. The play covers the east-west length of the province, and the north and south boundaries, in some places a fault, are defined by the extent of the Neogene sequence in the subsurface (fig. 54). Except for some remnants of the Neogene sequence along the Pine Mountain fault, the northern boundary is approximately equivalent to the south edge of the Santa Ynez and Topa Topa uplifts. The southern boundary, along the north side of the Santa Monica Mountains, is equivalent to the southern boundary of Neogene basin remnants.

Major reservoirs are unlithified turbidite sands of the Pliocene and Pleistocene Pico Formation. Other important reservoirs are in the Miocene and lower Pliocene section, including marine sandstone and fractured, finegrained rocks of the Rincon, Monterey, Modelo, Sisquoc, and Santa Margarita Formations (fig. 53). Fractured, fine-grained siliceous rocks of the Monterey Formation are important reservoirs in a few onshore fields and in State waters. Reservoir thicknesses range from less than $100 \mathrm{ft}$ to approximately $5,000 \mathrm{ft}$; depth to the top of reservoirs ranges from about $150 \mathrm{ft}$ to $14,000 \mathrm{ft}$. Limited data available on discovered reservoirs indicate a range of 18-26 percent porosity and 51-537 millidarcies permeability for the Pico and younger reservoirs, and 11-30 percent porosity and 24-270 millidarcies permeability for the Monterey and Modelo Formations.

Potential source rocks are organic-rich mudrocks of Miocene and early Pliocene age, including the Rincon, Monterey, Modelo, Sisquoc, and Santa Margarita Formations, and possibly the lower part of the Pico Formation, although the most likely source is the Monterey Formation. The Monterey contains excellent oil-prone source rocks with total organic carbon as high as 23 percent in some beds and organic matter of marine and mixed marine-continental origin. Most of the oil was probably generated in the Santa Clara trough and other deep areas of the play where the Pliocene and Pleistocene sequence is approximately 20,000 ft thick. Migration probably took place, for the most part, during the Pleistocene, after the onset of compressional tectonics, which formed most of the structural traps in the play.

Traps are mainly anticlinal with associated faulting, but several important fields are purely stratigraphic. Adequate seals are provided by impermeable shale and fine-grained rocks in the Neogene sequence. The deepest well in the basin reached a total depth of $21,500 \mathrm{ft}$, bottoming within the upper Miocene section. Maximum thickness of the lower Miocene to Pleistocene sedimentary sequence is estimated to exceed $26,000 \mathrm{ft}$.

The play has been extensively explored since the Santa Paula field was discovered in 1861 . Thirty-four oil fields produce solely from the Neogene play, and 7 have both Paleogene and Neogene production. Average ultimate recovery for fields in the play is approximately $53 \mathrm{MMBO}$; the largest, at $1.24 \mathrm{BBO}$, is the Ventura-Rincon field.

Future resource potential of the play is estimated to be very good, especially in the Santa Clara trough and its extension into State waters, and also beneath the hanging wall of the San Cayetano thrust fault. Smaller accumulations may also occur beneath the Pine Mountain fault and in other areas adjacent to the Santa Clara trough.

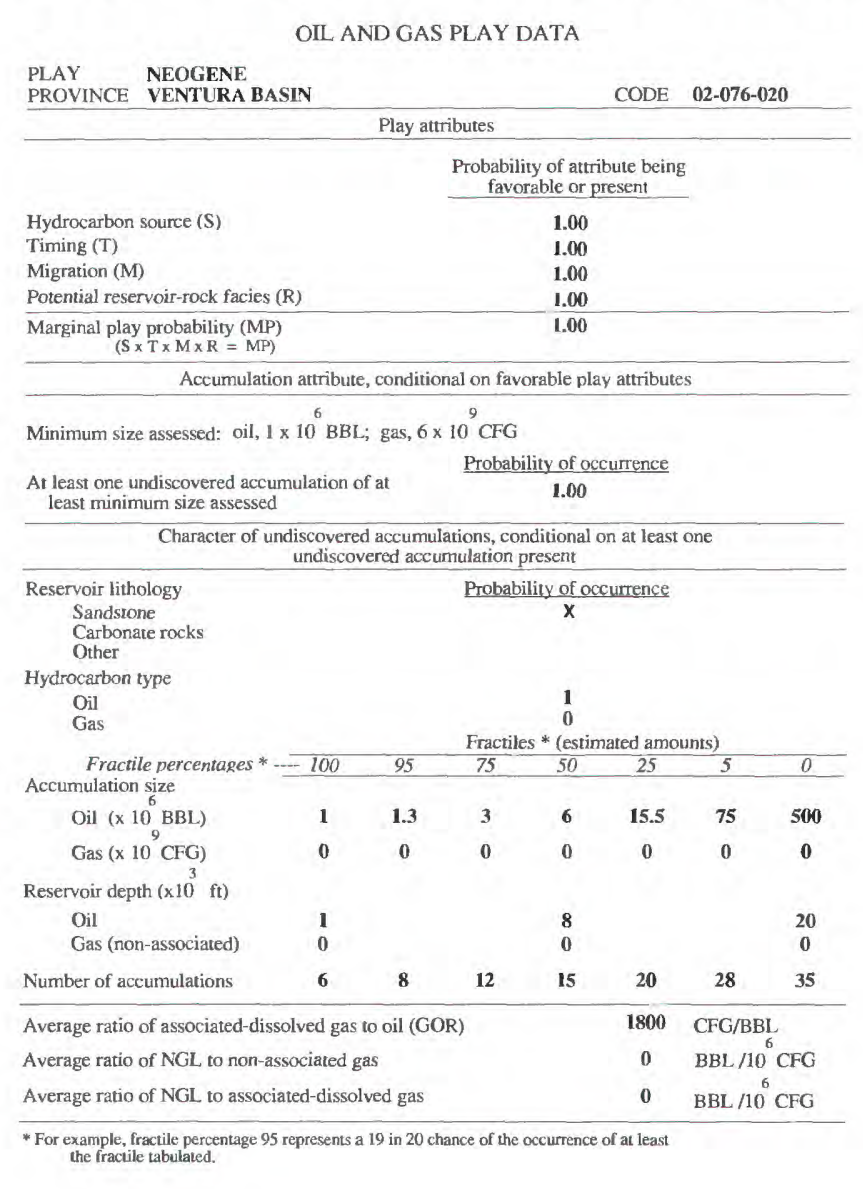


REGION 1, ALASKA; REGION 2, PACIFIC COAST

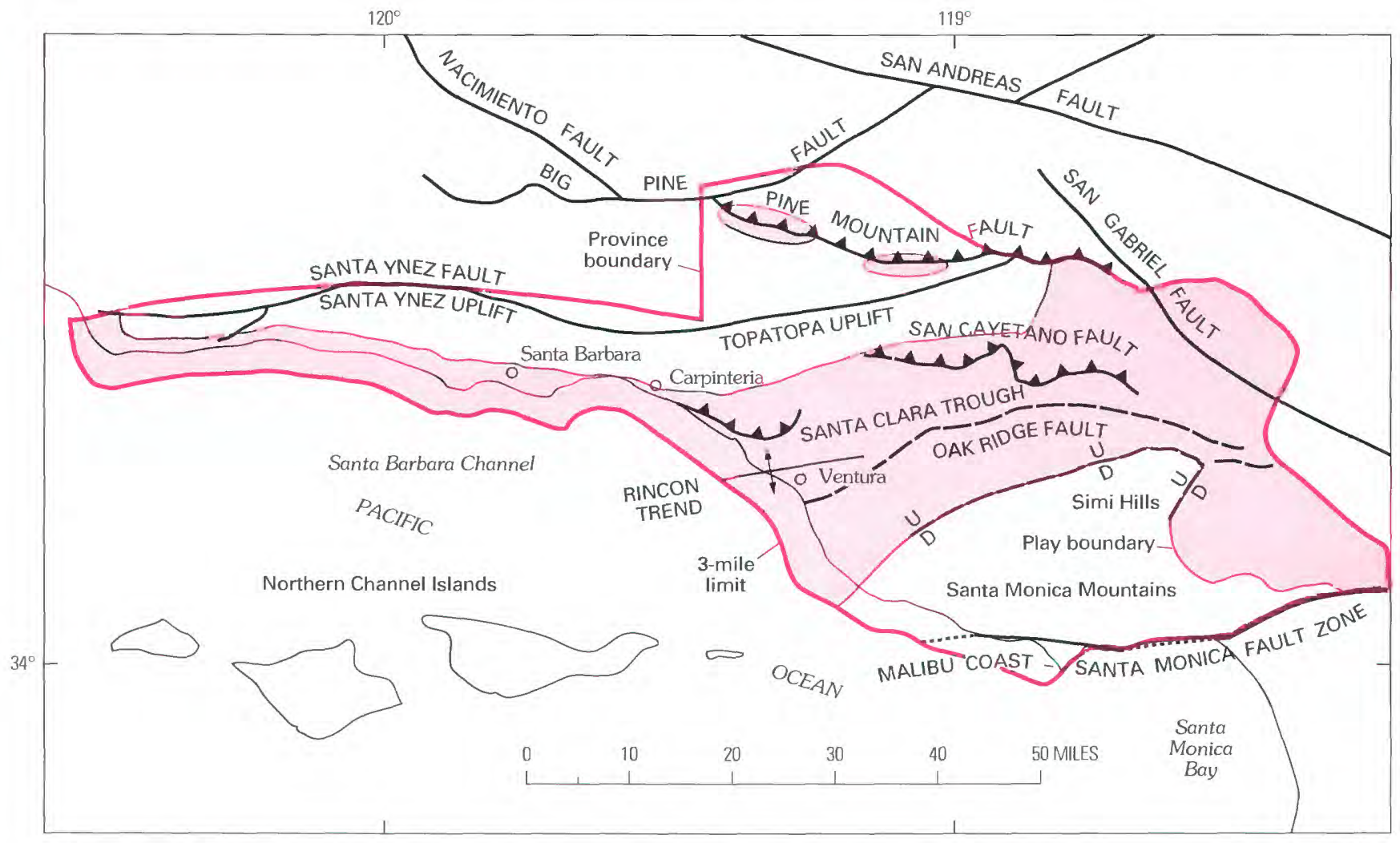

Figure 54. Map of Neogene play (076-020). On fault with sawteeth, teeth are on upthrown block. 


\section{PALEOGENE PLAY (030)}

The Paleogene play consists primarily of oil and associated gas accumulations, with condensate, trapped by structure, stratigraphy, or a combination of both in sandstone reservoirs of Late Cretaceous to early Miocene age (fig. 55). Dry (nonassociated) gas is also produced, mainly from fields in State waters off the Santa Barbara coast. The play covers almost the total province (excepting the basement outcrop in the southeast), with the assumption that a Paleogene or lower Miocene section has potential if present at depths greater than about $25,000 \mathrm{ft}$ in the Santa Clara trough.

Important reservoirs are sandstone units of the nonmarine Sespe Formation in areas both north and south of the Santa Clara trough. The Sespe commonly has good to excellent reservoir properties and can reach 7,000 $\mathrm{ft}$ thick in the subsurface. Another important reservoir, commonly coproduced with the Sespe, is the overlying shallow-marine Vaqueros Formation. The Vaqueros can be $300 \mathrm{ft}$ thick and in places has excellent reservoir properties. Limited porosity and permeability data from Vaqueros and Sespe reservoirs show a range of 19-25 percent porosity and 235-400 millidarcies permeability. Reservoir thickness ranges from 50 to $3,000 \mathrm{ft}$, and depth to the top of reservoirs is $100-11,500 \mathrm{ft}$. Other important reservoirs are the Matilija Formation, Coldwater Sandstone, and Llajas Formation of Eocene age. Paleocene clastic rocks south of the Santa Clara trough along with Upper Cretaceous sandstone and conglomerate are less important reservoirs. Minor production from Cretaceous reservoirs in the Simi Hills has been abandoned.

Source rocks are mainly organic rich mudrocks of the Rincon Shale, and the Monterey, Modelo, Sisquoc, and Santa Margarita Formations. However, carbon isotopic data suggest a second hydrocarbon source, probably Eocene marine shale, in the western area of the play. Marine shale of the Llajas Formation also appears to be a suitable source rock south of the Oak Ridge fault where oil is produced from interbedded sandstones in the Llajas. Other possible source rocks include marine shale units in the Cretaceous and Paleogene sections, although their potential for generating oil or gas is relatively unknown. Most hydrocarbons in the play were probably generated from Miocene source rocks in the Santa Clara trough and other deep areas. Migration from Miocene source rocks probably took place after the onset of Pleistocene compressional tectonics, which formed most of the structural traps.

Traps are mainly anticlines and faulted anticlines. South of the Oak Ridge fault, in the major producing trend in the play, numerous oil accumulations occur in Eocene and Oligocene sandstone reservoirs in anticlinal traps. Other traps include a homocline with tar seal, significant unconformities, and closure created by faults and dip reversals. Marine shale units within the Cretaceous, Paleogene, and Neogene sequences all provide seals.

Since the discovery of the Sespe field in 1887 , some parts of the play have been extensively explored, but not the rugged mountainous areas of the north, or areas where the overlying Neogene sequence is productive. Of the 31 oil and gas fields in the play, 7 are solely gas fields and 7 also produce from the Neogene section. Ultimate recovery from the largest oil field, South Mountain, is estimated at $117 \mathrm{MMBO}$; the average field size is approximately $27 \mathrm{MMBO}$. Ultimate recovery from the largest gas field, Molino Offshore, is estimated at $330 \mathrm{BCF}$; the average field size is $74 \mathrm{BCF}$.

The play is estimated to have a medium potential for undiscovered oil and gas. In the Santa Clara trough possible reservoirs, if present, may be too deep to retain favorable porosity and permeability; however, this potential remains untested. Undiscovered resources may also occur on the northern and southern margins of the Santa Clara trough, including State waters.

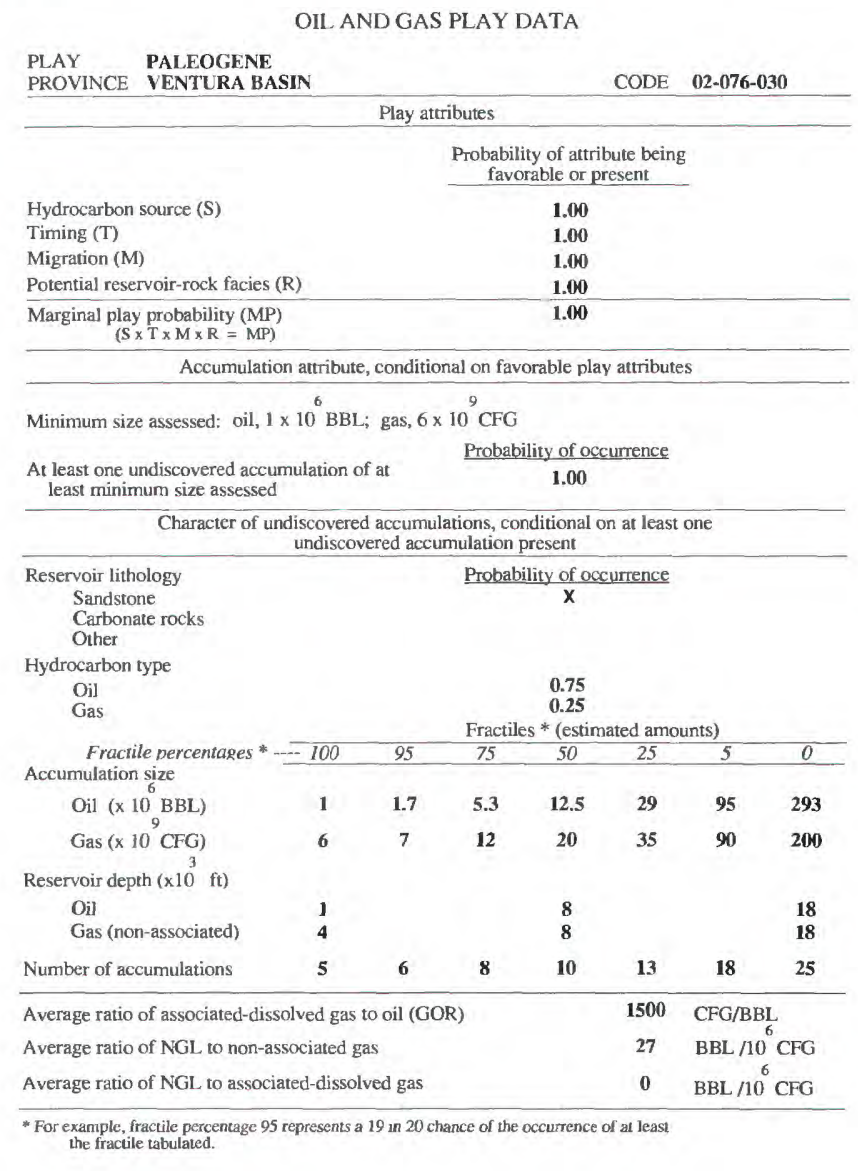


REGION 1, ALASKA; REGION 2, PACIFIC COAST

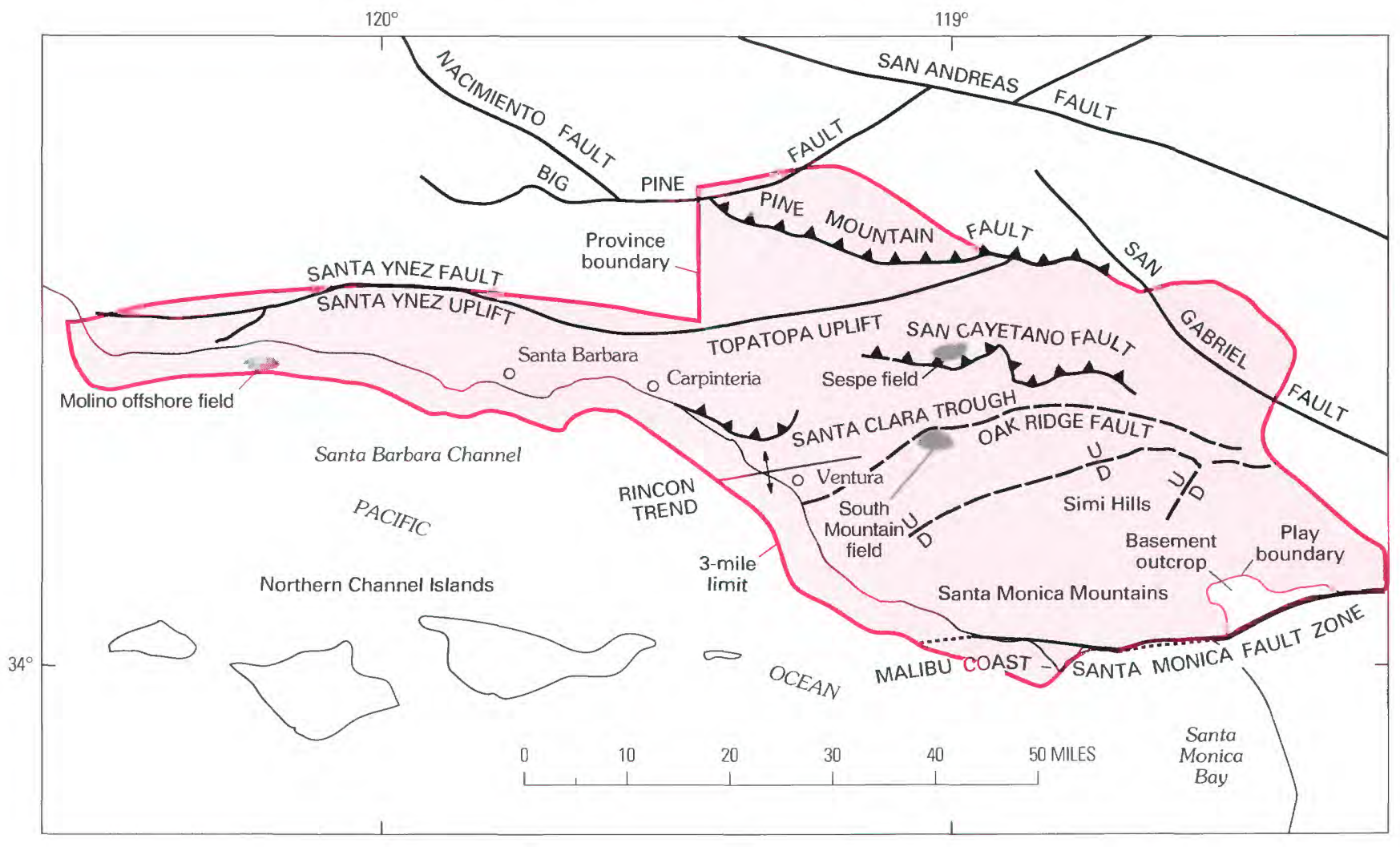

Figure 55. Map of Paleogene play (076-030). On fault with sawteeth, teeth are on upthrown block. 


\title{
SANTA MARIA BASIN PROVINCE (077)
}

\author{
By Caroline M. Isaacs
}

\section{INTRODUCTION}

The Santa Maria Basin province, located along the tectonically complex central California coast, includes a number of small Neogene sedimentary basins and basin fragments. Deposited in several composite sutured terranes on basement rocks that are mainly Cretaceous and older (fig. 56), the Neogene sedimentary rocks are as much as $15,000 \mathrm{ft}$ thick. The province is about $200 \mathrm{mi}$ long and about $10-50 \mathrm{mi}$ wide. To the south, it is bounded by the Santa Ynez fault. On the northeast, it is generally bounded by the Sur-Nacimiento fault but extends beyond that fault north of lat $36^{\circ} \mathrm{N}$. to include the approximate extent of exposed pre-Cretaceous metamorphic basement rocks. To the west, the State 3-mile limit forms the seaward boundary of the province.

Cumulative production from 14 major oil fields through 1986 was $798 \mathrm{MMBO}$ (including NGL), and 796 BCFG. The first major oil field was discovered in 1901, and five others were discovered in 1910. The largest oil field (Santa Maria Valley) was discovered in 1934, followed by the discovery of seven other major fields in the 1940's and 1950's. Smaller discoveries and field extensions have continued to the present. One play was individually assessed, the Neogene play. 
REGION 1, ALASKA; REGION 2, PACIFIC COAST

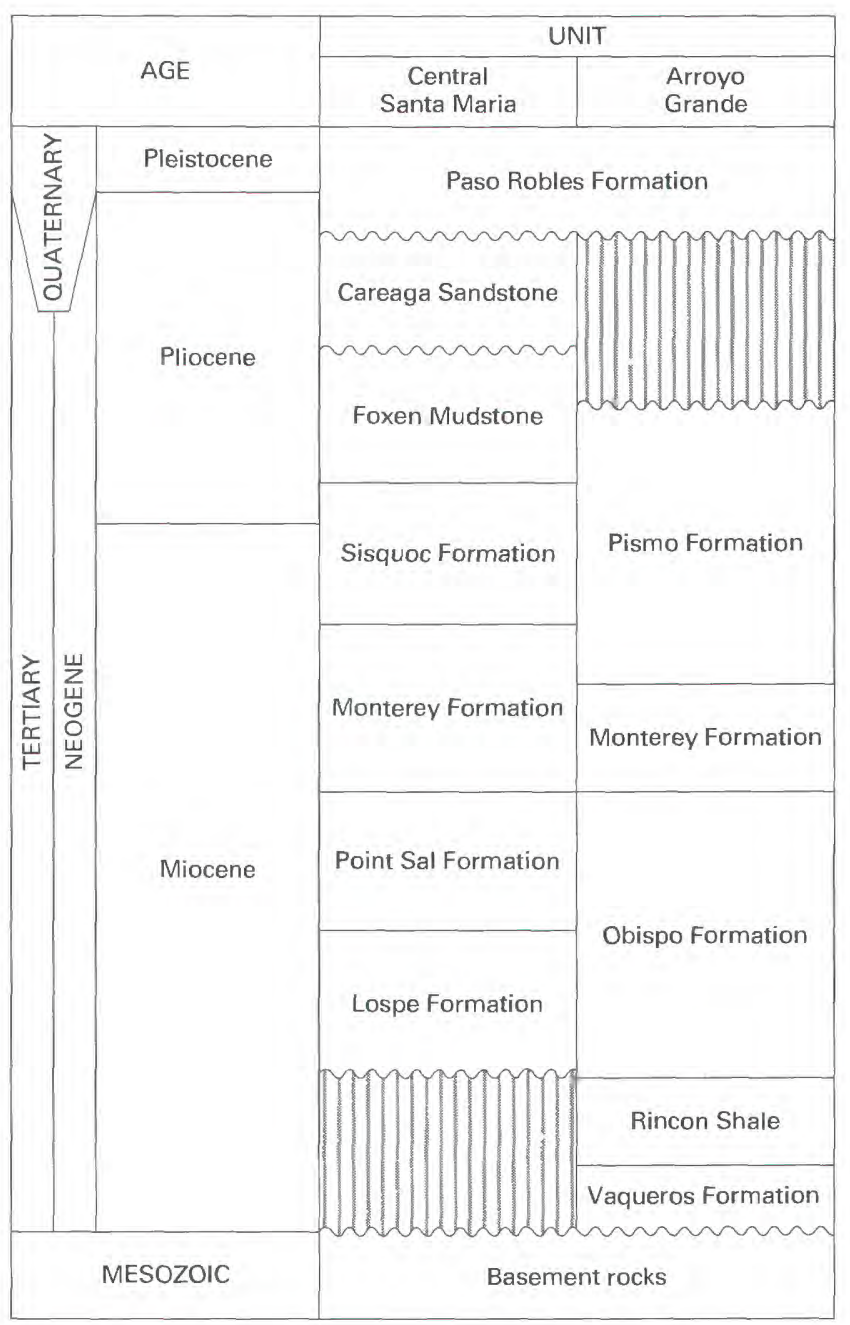

Figure 56. Generalized stratigraphic column, Santa Maria Basin province (077). Vertical line pattern, hiatus. Wavy line, unconformity. 


\section{NEOGENE PLAY (020)}

The Neogene play includes structural, stratigraphic, and combination traps in fractured chert-shale reservoirs and conventional sandstone reservoirs of Miocene and Pliocene age. The play, approximately $60 \mathrm{mi}$ long and $20-50 \mathrm{mi}$ wide (fig. 57), is limited only by the subsurface extent of Neogene strata. Maximum thickness of sedimentary rocks is estimated to be about $15,000 \mathrm{ft}$. Known reservoir rocks include fractured chert, calcareous shale, porcelanite, and dolostone in the Miocene Monterey Formation; permeable sandstone beds in the Miocene Point Sal Formation, MiocenePliocene Sisquoc Formation, Miocene and Pliocene Pismo Formation, and Pliocene Foxen Mudstone, and fractured hard sandstone in Mesozoic basement, Miocene Lospe Formation, and Miocene Point Sal Formation (fig. 56). Total reservoir thicknesses range from 45 to $3,065 \mathrm{ft}$. In fractured reservoirs, porosity is very poor to very good and matrix permeability is very poor, whereas in permeable sandstone reservoirs porosity and permeability are good.

Source rocks are mainly marine and mixed marine-continental oil-prone mudrocks of the Miocene Monterey Formation. Both source rocks and oils are generally high in sulfur, and oils tend to be heavy $\left(<20^{\circ} \mathrm{API}\right)$, although some light oils $\left(>30^{\circ} \mathrm{API}\right)$ have been found. The wide range of oil gravities $\left(6^{\circ}-35^{\circ}\right.$ API $)$ may be largely the result of different generation and expulsion times, or of facies differences related to source-rock variations.

Oil generation probably occurred in deep parts of the synclines adjacent to structural and stratigraphic traps. Known traps are both structural and stratigraphic. Structural traps are mainly faulted anticlines but also include faulted homoclines, noses, and domes. Stratigraphic traps are mainly overlap-truncation traps but also include lenticular sandstones and permeability barriers. Impermeable shale, chert, and carbonate rocks form adequate seals throughout the Neogene sequence. Drilling depths range from $<500$ to $12,500 \mathrm{ft}$, and average depths to the top of reservoir zones range from 700 to $6,000 \mathrm{ft}$.

Production in the play dates to the early 1900's: six major (>1 MMB) oil fields were discovered from 1901 to 1909 and eight additional fields through 1956. The largest field is the Santa Maria Valley Main, discovered in 1934 (fig. 57). Of the major fields, three have cumulative production plus proven reserves exceeding $100 \mathrm{MMBO}$, seven are in the range of 10-100 MMBO, and four are in the range of 1-10 MMBO. Four smaller fields have cumulative production plus proven reserves in the range of 0.1-1.0 MMBO. More recent discoveries are classed mainly as field extensions but include significant additions to reserves. Future resource potential is fair to good, and excellent in relatively unexplored State waters. 
REGION 1, ALASKA: REGION 2, PACIFIC COAST

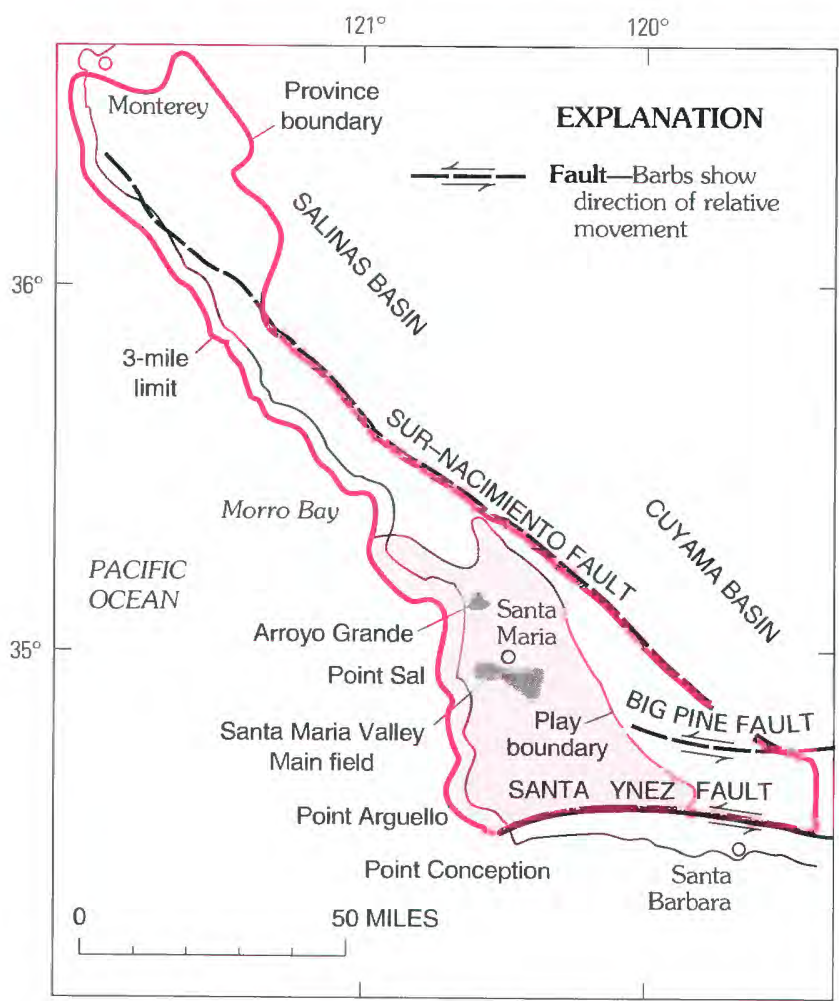

Figure 57. Map of Neogene play $(077-020)$

OIL AND GAS PLAY DATA

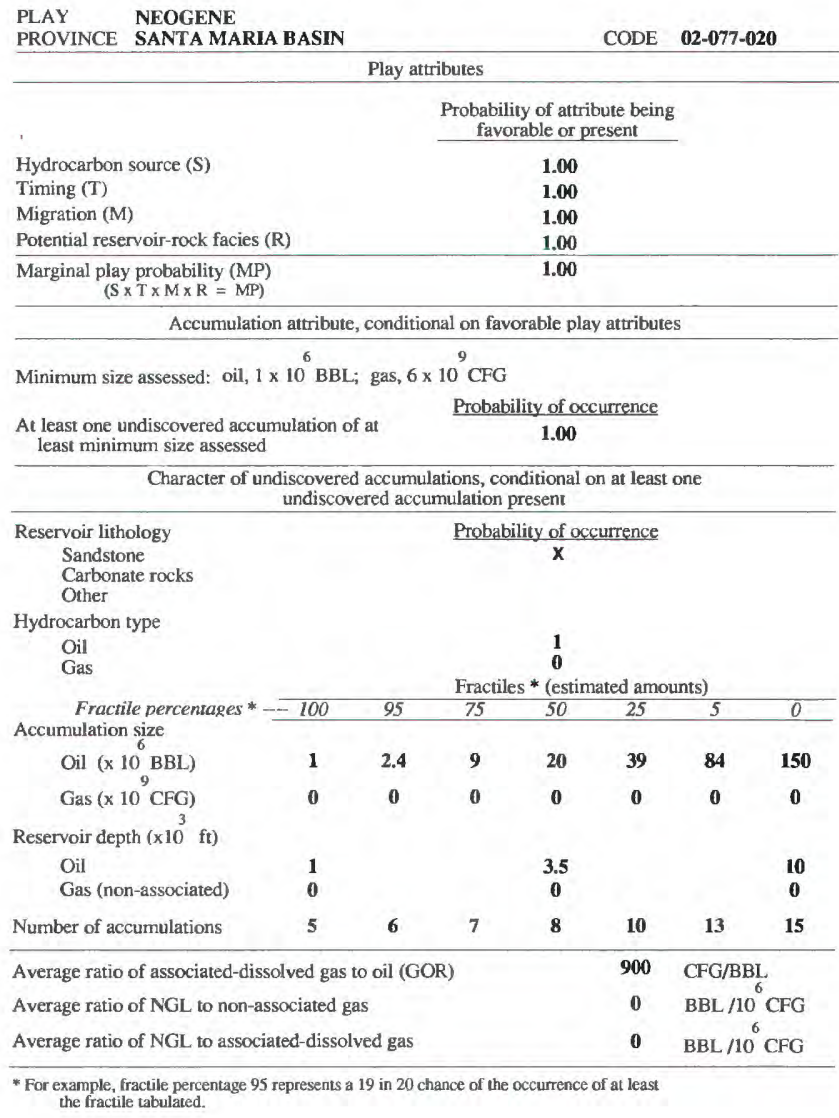




\title{
CENTRAL COASTAL BASINS PROVINCE (078)
}

\author{
By Caroline M. Isaacs
}

\section{INTRODUCTION}

The Central Coastal Basins province, located in the central California coastal area, includes three major Neogene basins, the Salinas, Cuyama, and $\mathbf{L a}$ Honda basins. Deposited on basement rocks of the Salinian composite terrane, Cretaceous and Cenozoic sedimentary rocks (fig. 58) in the province are as much as $30,000 \mathrm{ft}$ thick. The province is about $275 \mathrm{mi}$ long and $10-35 \mathrm{mi}$ wide, bounded by the San Andreas fault to the northeast and by the Big Pine fault to the south. To the southwest, it is bounded by the Sur-Nacimiento fault, except north of lat $36^{\circ} \mathrm{N}$., where exposed pre-Cretaceous metamorphic basement rocks northeast of this fault are excluded from the province area. To the west, from Monterey northward, the State 3-mile limit forms the seaward boundary of the province.

Cumulative production through 1986 from seven major oil fields was $688 \mathrm{MMBO}$ (including NGL), and 353 BCFG. The first major discovery in the province, the giant San Ardo field, was made in the Salinas basin in 1947; its production plus proven reserves through 1986 is $530 \mathrm{MMBO}$. The first major discovery in the Cuyama basin followed in 1948. All major fields were discovered in the 1940's and 1950's, though smaller discoveries and field extensions have continued to the present. One play was individually assessed, the Neogene play. 
REGION 1, ALASKA; REGION 2, PACIFIC COAST

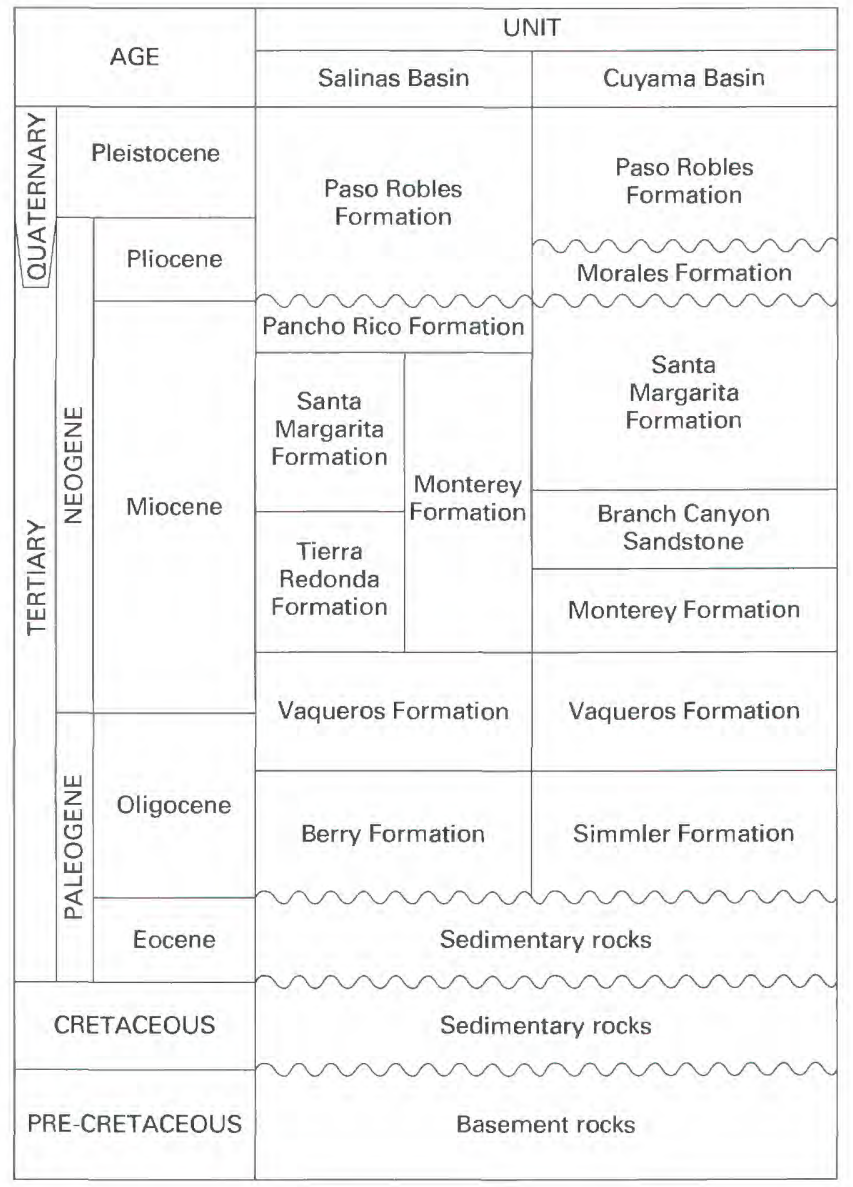

Figure 58. Generalized stratigraphic column, Central Coastal Basins province (078). Wavy line, unconformity. 


\section{NEOGENE PLAY (020)}

The Neogene play is characterized by hydrocarbon accumulations in structural, stratigraphic, and combination traps in sandstone reservoirs mainly of Miocene age. The play covers nearly the entire province and is approximately $250 \mathrm{mi}$ long and 10-35 mi wide (fig. 59). It is limited only by the subsurface extent of Neogene strata. Maximum thickness of sedimentary rocks is estimated to be about $30,000 \mathrm{ft}$ (in the La Honda basin). Known reservoir rocks are mainly sandstone of Miocene age in the Vaqueros Formation, Tierra Redonda Formation, Monterey Formation, and Santa Margarita Formation; minor reservoir rocks include sandstone in the Pliocene Morales Formation (fig. 58). Total reservoir thicknesses range from 70 to $600 \mathrm{ft}$. Porosity and permeability are generally good, particularly in shallow sandstone reservoirs.

Source rocks are thought to be mainly marine and mixed marine-continental oilprone mudrocks of the Miocene Monterey Formation. Other potential source rocks in the play include Cretaceous shale, Eocene shale, and Miocene shale within the Vaqueros Formation. Oils are heavy $\left(10^{\circ}-19^{\circ} \mathrm{API}\right)$ in the Salinas basin and light $\left(26^{\circ}-46^{\circ}\right.$ API) in the Cuyama basin. Oil generation probably occurred in deep parts of the basins and migrated upstructure to adjacent structural and stratigraphic traps. Known traps are faulted anticlines and homoclines, sandstone pinchouts, permeability barriers, and overlap-truncation stratigraphic traps. Impermeable shale forms adequate seals in much of the Neogene sequence. Average drilling depths to the top of reservoir zones range from 1,900 to $5,800 \mathrm{ft}$.

About 1,000 exploratory wells have been drilled in the play, and production dates back to the 1940's, with all six major (>1 MMBO) fields discovered between 1947 and 1959. Of these fields, one (the San Ardo field) has cumulative production plus proven reserves exceeding $500 \mathrm{MMBO}$, one field is in the range of 100-500 MMBO, one other field is in the range of $10-100 \mathrm{MMBO}$, and the remaining three fields are in the range of 1-10 MMBO. Eleven smaller fields have cumulative production plus proven reserves in the range of 0.1-1.0 MMBO. Future resource potential in the play is fair to good. 


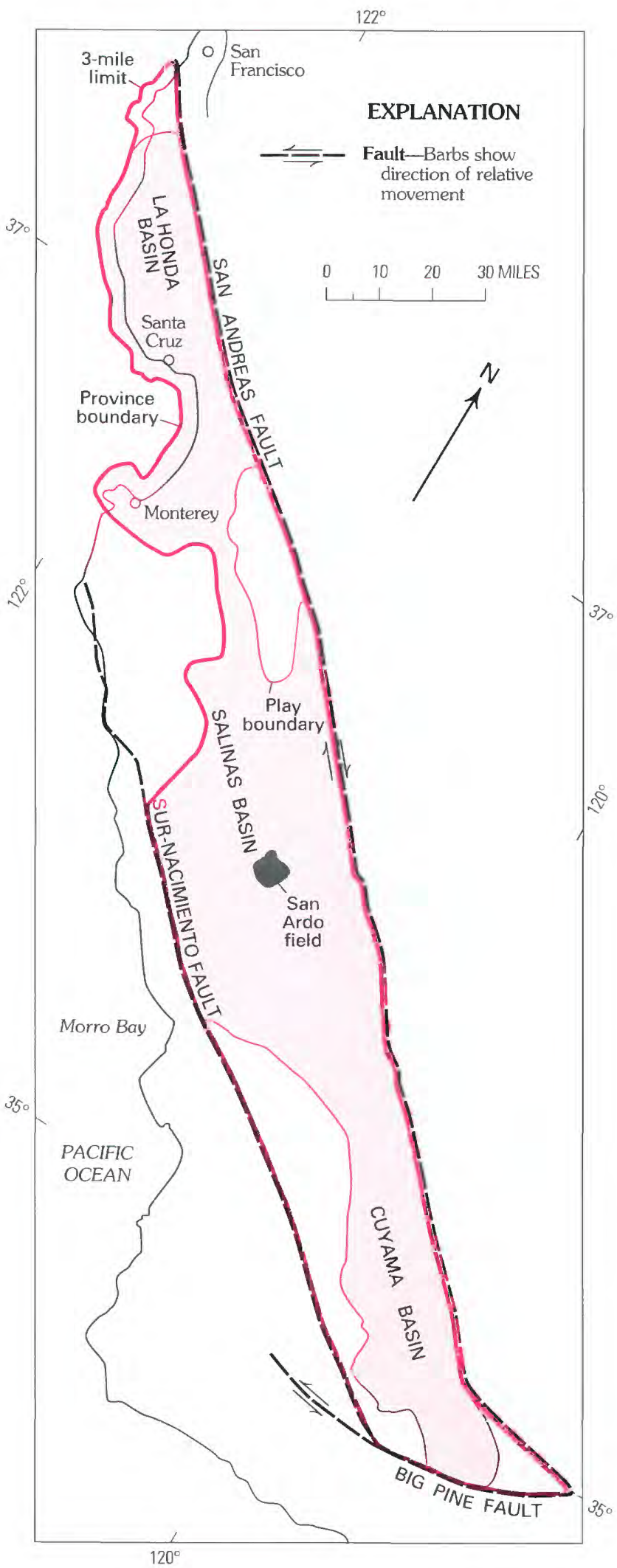

Figure 59. Map of Neogene play (078-020).

OIL AND GAS PLAY DATA

PLAY NEOGENE

PROVINCE CENTRAL COASTAL BASINS CODE 02-078-020

Play attributes

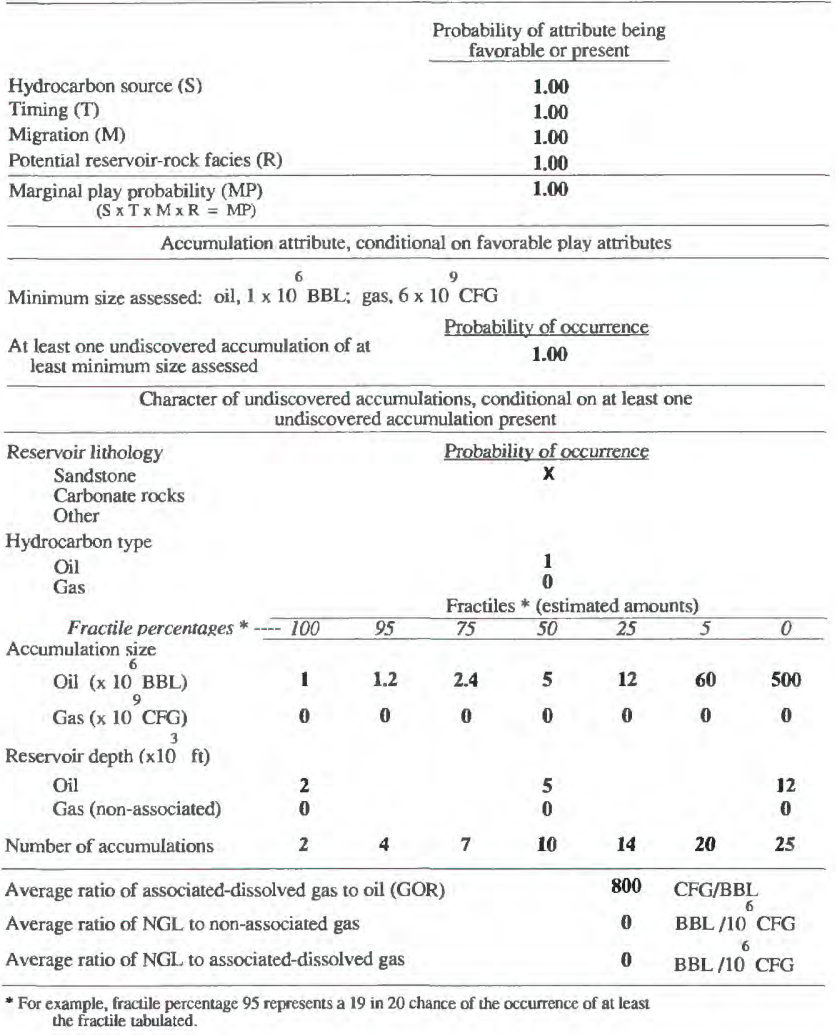




\title{
SONOMA-LIVERMORE BASINS PROVINCE (079)
}

\author{
By Hugh McLean
}

\section{INTRODUCTION}

This northwest-trending province is a composite of three Tertiary basins, Sonoma, Orinda, and Livermore, that lie east and north of the San Francisco Bay area. San Pablo Bay separates the Sonoma basin on the north from the Orinda and Livermore basins to the south and east. The western boundary of the province is the Hayward-Tolay fault for the Sonoma and Orinda basins, with the Sunol-Calaveras fault separating the Orinda and Livermore basins. The eastern province boundary is the western flank of the Sacramento Basin province (073). The province is about $100 \mathrm{mi}$ long and from 10 to $12 \mathrm{mi}$ wide.

Several small hydrocarbon accumulations are known in the province. The Petaluma oil and gas field was discovered in 1926 in the Sonoma basin. This field, now shut-in, produced a total of 14,000 BO and 1.3 BCFG from Pliocene strata (fig. 60) and volcanic units at a depth of 1,200 ft. Deeper drilling through Eocene rocks has revealed only minor oil and gas shows. Few wells have been drilled in the Orinda basin, all with negative results. In the Livermore basin, exploratory drilling resulted in the discovery of the Livermore oil field in 1967, which produces from Tertiary and Upper Cretaceous reservoir rocks at a depth of $2,000 \mathrm{ft}$ and is located on a folded and faulted anticlinal nose. Cumulative production to the end of 1986 from the field was $1.57 \mathrm{MMBO}$. The Hospital Nose gas field is now abandoned after producing $14 \mathrm{MMCFG}$. One play was individually assessed in the province, the Livermore Structure play. 
REGION 1, ALASKA; REGION 2, PACIFIC COAST

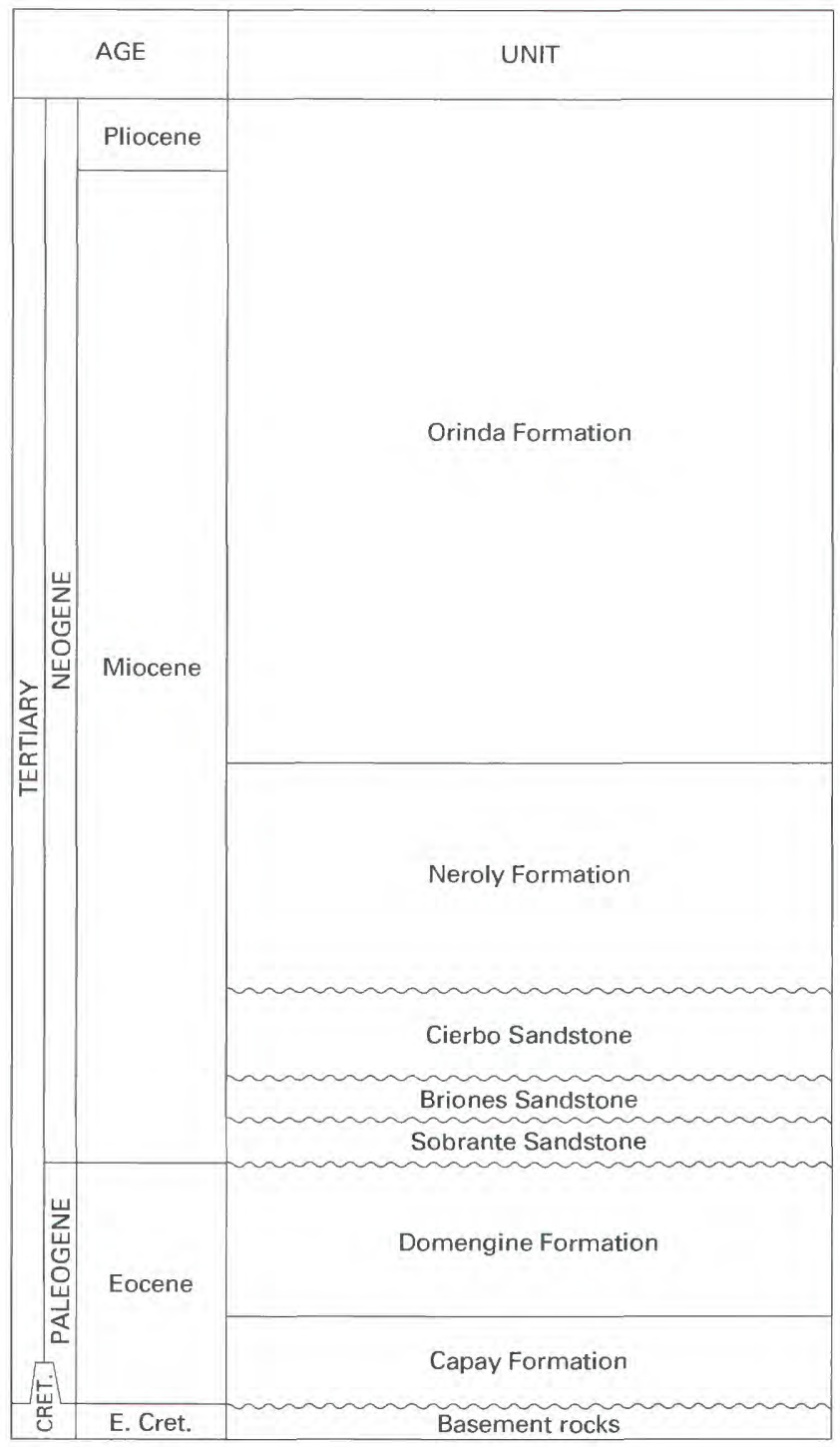

Figure 60. Generalized stratigraphic column for Livermore basin part of Sonoma-Livermore Basins province (079). Wavy line, unconformable contact. 


\section{LIVERMORE STRUCTURE PLAY (020)}

The Livermore Structure play, limited to the Livermore basin part of the SonomaLivermore Basins province, contains anticlinal and possible fault-block traps in clastic reservoirs of late Miocene, Pliocene, and Pleistocene age. The play is about $180 \mathrm{mi}^{2}$ in extent (fig. 61). The Livermore basin is bounded on the west by the Sunol-Calaveras fault and on the north, east, and south by nonprospective pre-Tertiary rocks. This basin contains more than $20,000 \mathrm{ft}$ of folded and faulted Neogene sedimentary fill, and may have formed as the result of wrench faulting on strike-slip faults.

Known reservoir rocks are shallow-marine siliciclastic sandstone beds in the upper Miocene Cierbo and Briones Sandstones (fig. 60). Porous and permeable sandstone beds probably exist in overlying Pliocene strata as well. Total reservoir thicknesses probably range from $50 \mathrm{ft}$ to as much as $200 \mathrm{ft}$.

Source rocks are marine mudstone and shale beds that are interbedded with Neogene sandstone and conglomerate as well as Upper Cretaceous and Paleogene pelitic strata that unconformably underlie the Neogene fill. Oil and gas generation and migration probably occurred in late Pliocene or Pleistocene time, as the basin deepened and was folded by right-slip wrench faulting, which continues to the present time. Presumably the same source rocks in the play generated both oil and dry gas.

Potential traps include those on anticlines and in the hanging-wall fault blocks of adjacent, parallel high-angle faults. Adequate seals are formed by numerous interbedded shale beds and tuffaceous strata in the Neogene section. Drilling depths range from 1,000 to $15,000 \mathrm{ft}$ or more.

Drilling was originally stimulated by oil seeps known since the early 1800 's. More than 55 wells have been drilled in and around the Livermore oil field, the only oil discovery in the play. During 1986, the Livermore field's 11 productive wells averaged 6 barrels of oil per well per day. One well drilled in the early 1950's, located on a structural nose $3 \mathrm{mi}$ southwest of the oil field, discovered a small accumulation of natural gas that became known as the Hospital Nose gas field. A total of 14,183 MCFG was produced from rocks considered to be economic basement. The well was later abandoned as subcommercial. Future potential of the play is low and limited by the complex structure and rapid facies changes in the Neogene section. 


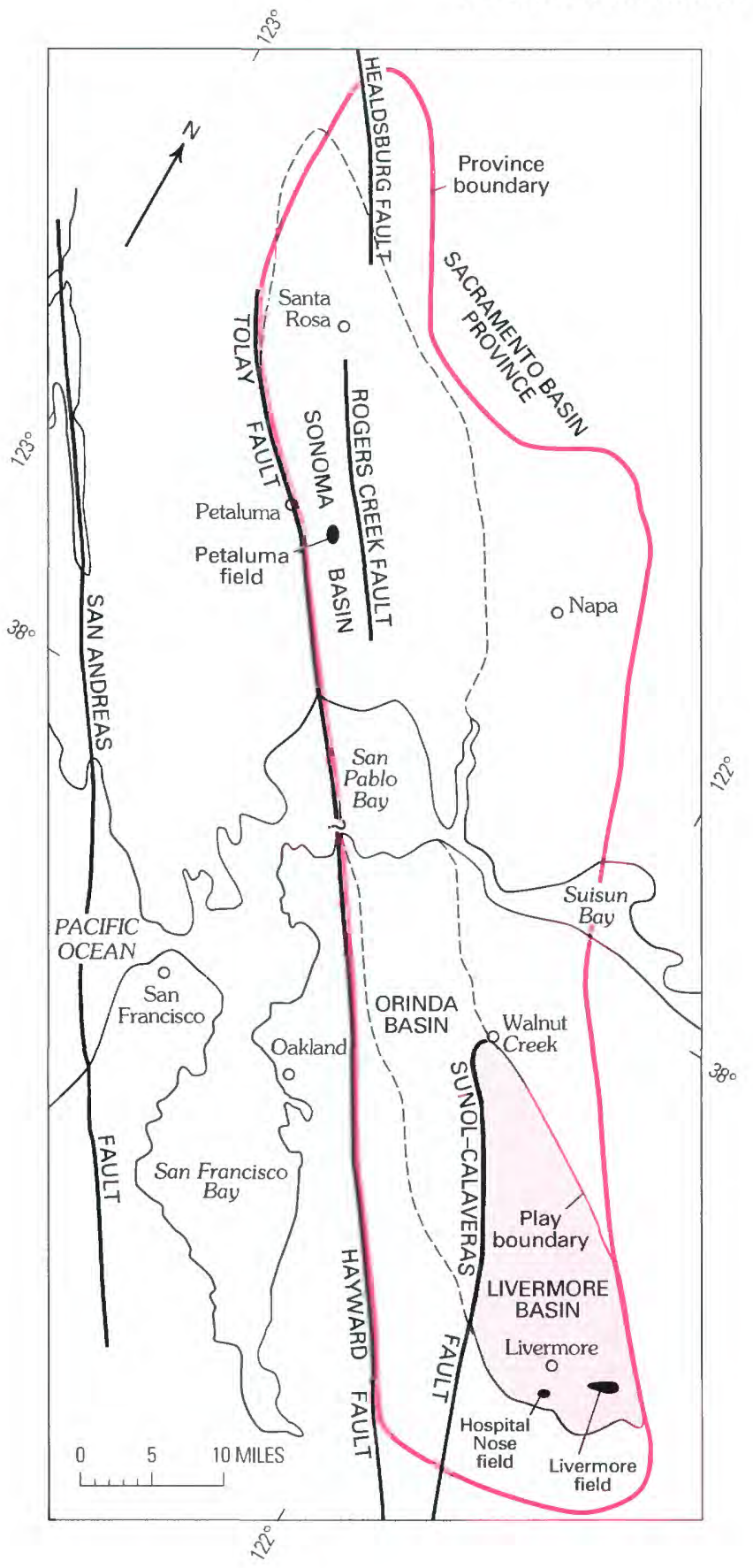

Figure 61. Map of Livermore Structure play (079-020). Fault queried where extent uncertain.

OIL AND GAS PLAY DATA

PLAY LIVERMORE STRUCTURE

PROVINCE SONOMA-LIVERMORE BASINS

Play attributes

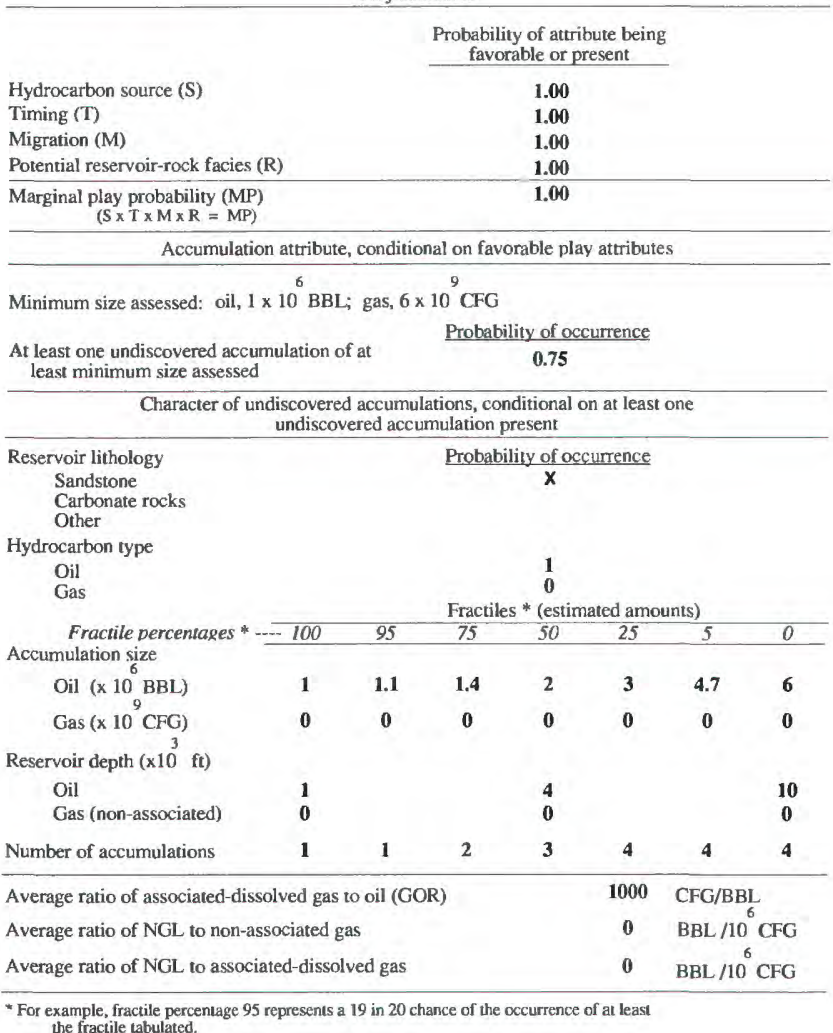




\title{
HUMBOLDT BASIN PROVINCE (080)
}

\author{
By Hugh McLean
}

\section{INTRODUCTION}

The Humboldt Basin province is located along the northwestern coast of California, and is transected by the northwesterly flowing Eel River. The province encompasses most of the onshore extent of the onshore-offshore Eel River basin. This forearc basin, 90 percent of which lies offshore, is located at the structurally complex junction of the North American, Gorda, and Pacific crustal plates. Two Neogene depositional sequences, totaling about $15,000 \mathrm{ft}$ of mostly marine deposits, constitute the basin fill (fig. 62). The present Eel River basin, a remnant of a more extensive basin, is segmented by rising anticlines that are underlain by active thrust and high-angle reverse faults. Thrust faults and shear zones bound the onshore extent of the basin.

The onshore Eel River basin (Humboldt Basin province) has been productive of gas since 1937. Of the many structures tested, only the Tompkins Hill and Table Mountain anticlines are gas-bearing. The Tompkins Hill field produces commercial amounts of gas at depths ranging from 2,000 to $5,000 \mathrm{ft}$. The Table Bluff field is subcommercial. Cumulative production from these fields to the end of 1986 was 89.7 BCFG. One play was individually assessed in the province, the Neogene Structure play. 
REGION 1, ALASKA; REGION 2, PACIFIC COAST

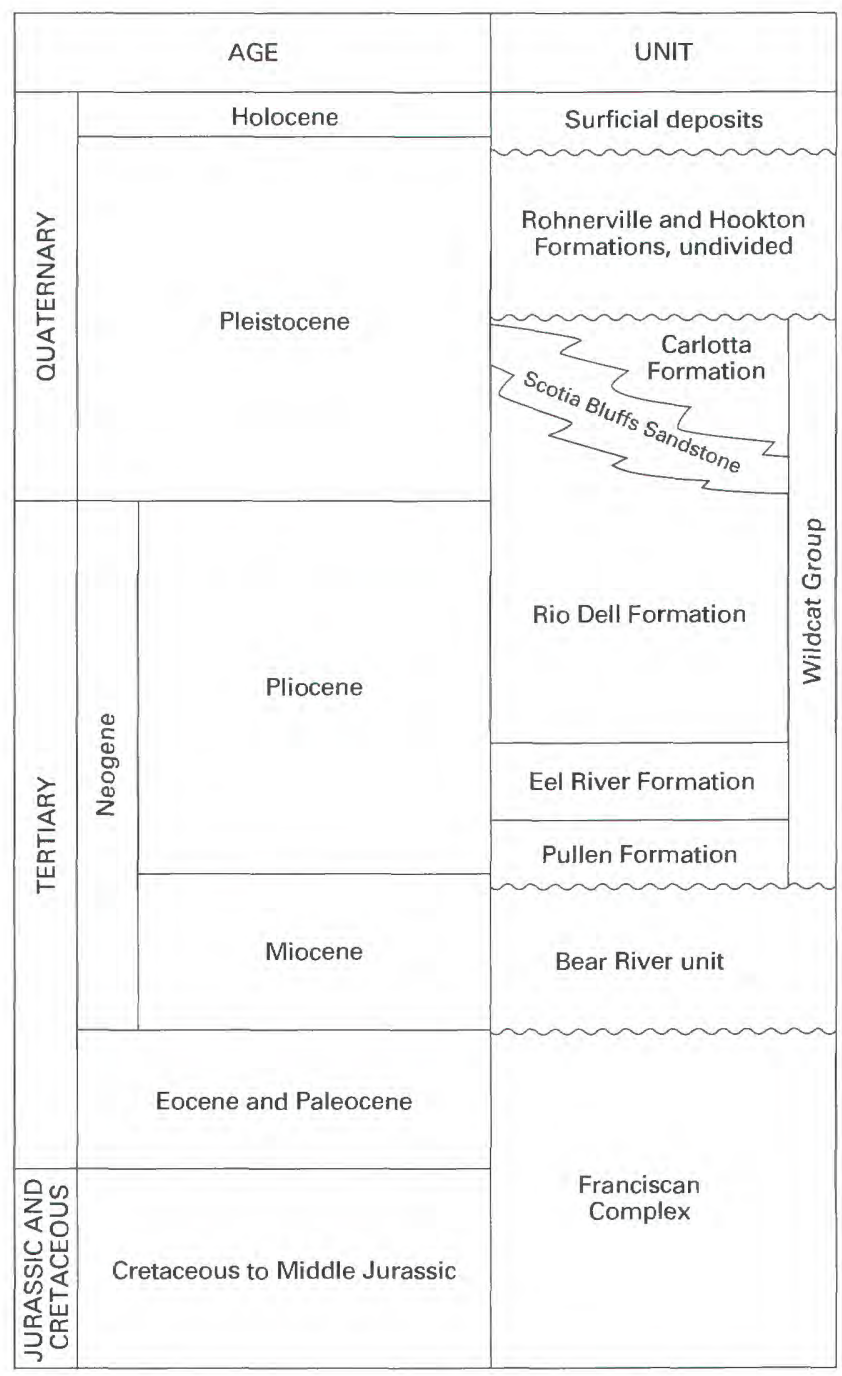

Figure 62. Generalized stratigraphic column, Humboldt Basin province (080). Wavy line, unconformable contact. 


\section{NEOGENE STRUCTURE PLAY (020)}

The play involves anticlinal traps in folded lower Miocene to Pleistocene clastic reservoirs. The onshore part of the play, including State waters, covers an area of approximately $225 \mathrm{mi}^{2}$ (fig. 63). The south and east edges of the Humboldt Basin province are faulted against economic basement rocks, whereas to the north the basin thins by onlap onto basement, and to the west the basin extends into State waters.

Dry gas is presently being produced from turbidite sandstone reservoirs interbedded with siltstone and mudstone in the Pliocene Rio Dell Formation (fig. 62). Porosity in the sandstone reservoirs may be as high as 25 percent. Reservoir intervals several hundred feet thick in the Tompkins Hill gas field produce between depths of 2,000 and $4,500 \mathrm{ft}$.

Source rocks are organic-rich shale and mudstone interbedded with the sandstone reservoirs. Other potential source beds include Miocene shale units whose total organic carbon contents range from 0.56 wt. percent to 1.39 wt. percent. Additional source rocks may exist in turbidite deposits of the Franciscan Complex, which unconformably underlies the Neogene basin fill. Gas generation and migration probably occurred in Pliocene or early Pleistocene time when the major anticlines (Table Bluff, Grizzly Bluff, and Tompkins Hill) were formed.

Anticlinal four-way closure forms the trap in the Tompkins Hill field, which is the main producing field; some of the closure may also involve fault blocks and stratigraphic pinchouts. Structural closure on the Tompkins Hill anticline is approximately $1,600 \mathrm{ft}$. Seals are provided by interbedded shale and mudstone.

The first discovery in the province was the Tompkins Hill gas field in 1937. This field has produced $89.6 \mathrm{BCFG}$ through 1986 . The gas is composed of 98 percent methane and is produced from 39 wells. Flow rates of gas in two other fields have been subcommercial, although exploration in the general area of these fields continues to the present. The Humboldt Basin province is currently in a mature stage of exploration and has a low future potential for undiscovered gas in structural traps; gas accumulations in stratigraphic traps remain as possible exploration targets. 


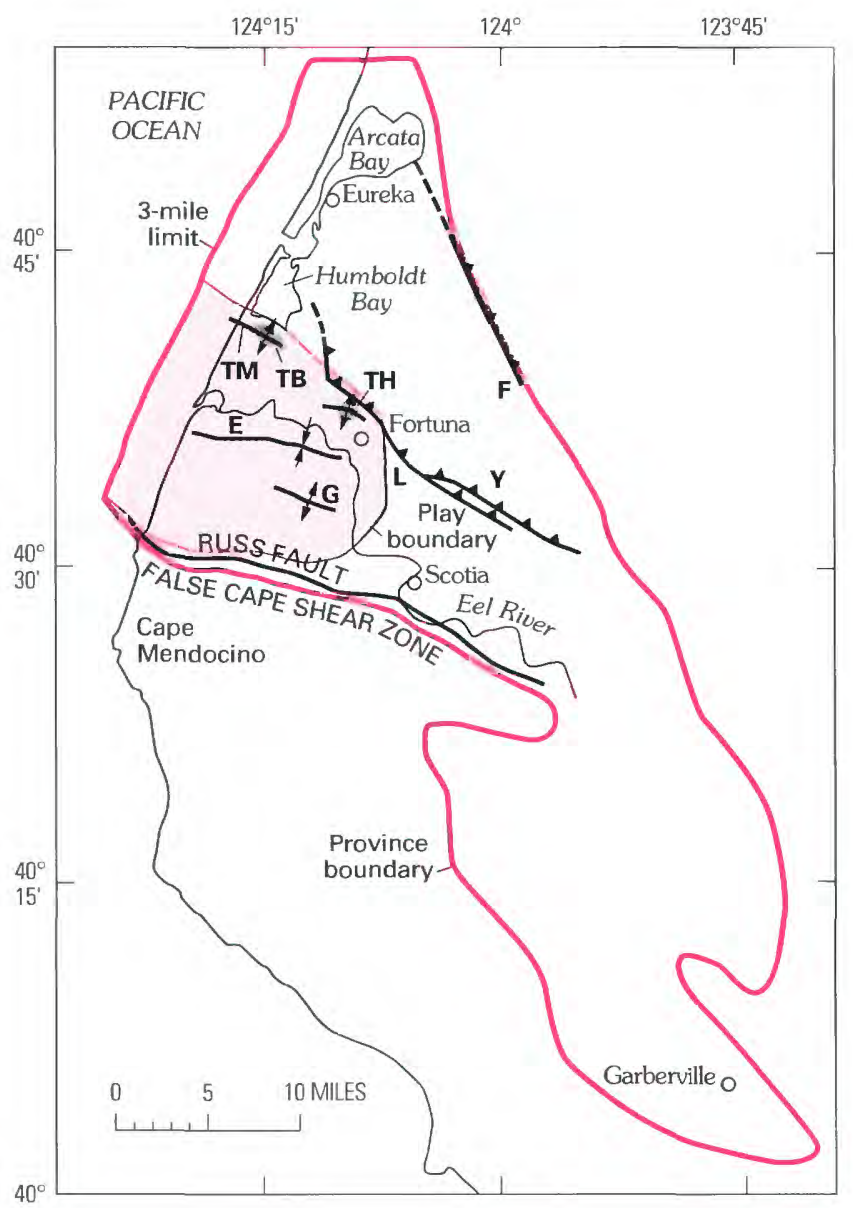

\section{EXPLANATION}

\begin{tabular}{|c|c|c|c|}
\hline גــــ & $\begin{array}{l}\text { Thrust fault-Dashed } \\
\text { where inferred; sawteeth }\end{array}$ & $f$ & Anticline \\
\hline $\mathbf{F}$ & & $\mathrm{TM}$ & $\begin{array}{l}\text { Table Mountain } \\
\text { anticline }\end{array}$ \\
\hline $\mathbf{Y}$ & & G & $\begin{array}{c}\text { Grizzly Bluff } \\
\text { anticline }\end{array}$ \\
\hline L & $\begin{array}{l}\text { Little Salmon thrust } \\
\text { fault }\end{array}$ & $\operatorname{san}$ & Gas field \\
\hline+ & Eel River syncline & $\begin{array}{l}\mathrm{TB} \\
\mathrm{TH}\end{array}$ & $\begin{array}{l}\text { Table Bluff gas field } \\
\text { Tompkins Hill gas } \\
\text { field }\end{array}$ \\
\hline
\end{tabular}

Figure 63. Map of Neogene Structure play (080-020).

OIL AND GAS PLAY DATA

PLAY NEOGENE STRUCTURE PROVINCE HUMBOLDT BASIN

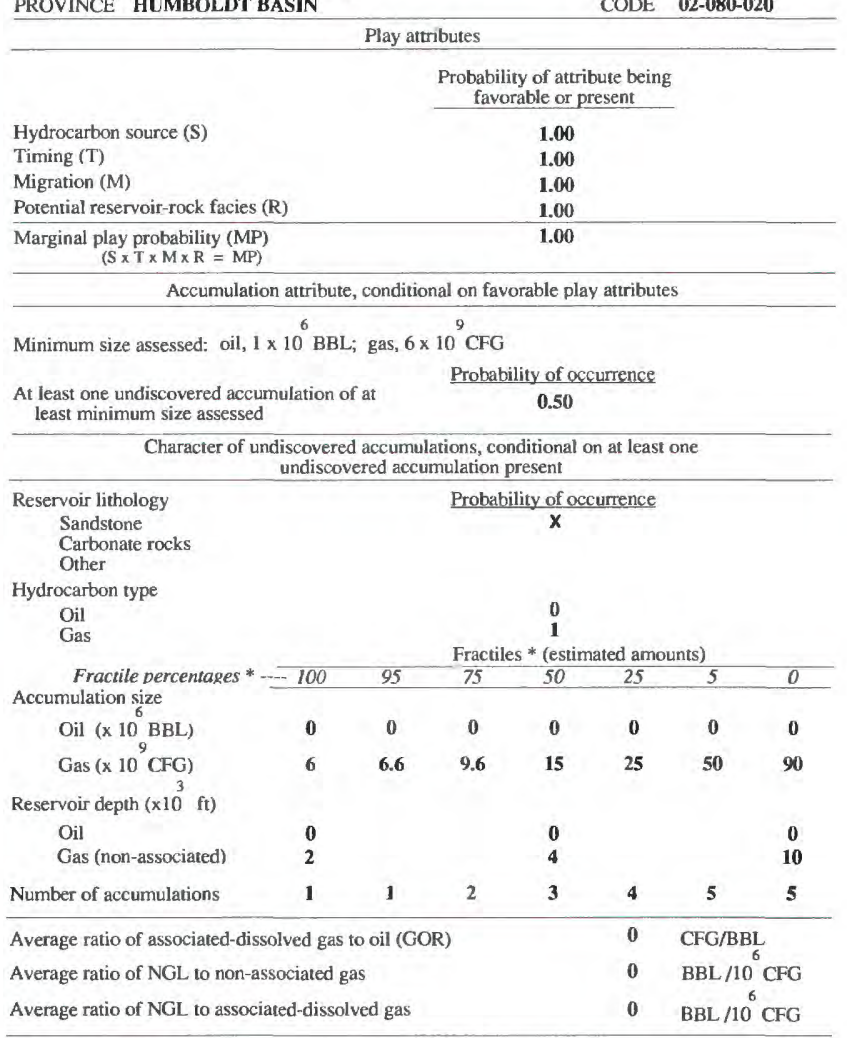

- For example, fractile percentage 95 represents a 19 in 20 chance of the occurrence of at least 


\title{
EASTERN OREGON-WASHINGTON PROVINCE (081)
}

\author{
By Marilyn E. Tennyson \\ INTRODUCTION
}

The province encompasses all of Oregon and Washington east of the High Cascades, as well as the North Cascades and the area immediately west of the North Cascades. Paleozoic and Mesozoic sedimentary, volcanic, and intrusive rocks within the province record a complex history of terrane accretion and continental margin arc tectonism during Mesozoic time. Widespread, locally very thick but discontinuous Paleogene fluvial sedimentary sequences were deposited during and following an Eocene episode of volcanism and transtensional deformation. Miocene flood basalt overlies these Paleogene rocks on the Columbia Plateau, whereas to the west, they are largely covered by Oligocene to Quaternary arc-associated volcanic and volcaniclastic rocks of the Cascades (fig. 64).

Production in the province has been exceedingly limited; from the 1920's to the 1940's a small gas field (Rattlesnake Hills) in southern Washington produced an estimated 1.3 BCF from sedimentary interbeds within Miocene flood basalt. Exploration has been sporadic. In north-central Oregon, a number of wells have been drilled either through Miocene basalt into underlying sedimentary rocks or directly into Mesozoic or Paleogene rocks exposed in windows in the basalt cover. A low but persistent level of interest has continued in the part of the province just south of the Canadian border and west of the North Cascades; the interest has focused on Mesozoic marine and Tertiary nonmarine sedimentary rocks. No discoveries have been made in either of these areas. During the 1980's, several important test wells were drilled in the northwestern Columbia Plateau. They demonstrated the presence of thick lower Tertiary nonmarine sedimentary sequences beneath the basalt, and gas shows were present in almost all of the wells. Some drillstem tests were run, but the amount of gas present was not commercial. No new wells have been drilled since the late 1980 's. The only play individually assessed was the sub-basalt Northwestern Columbia Plateau play. 
REGION 1, ALASKA; REGION 2, PACIFIC COAST

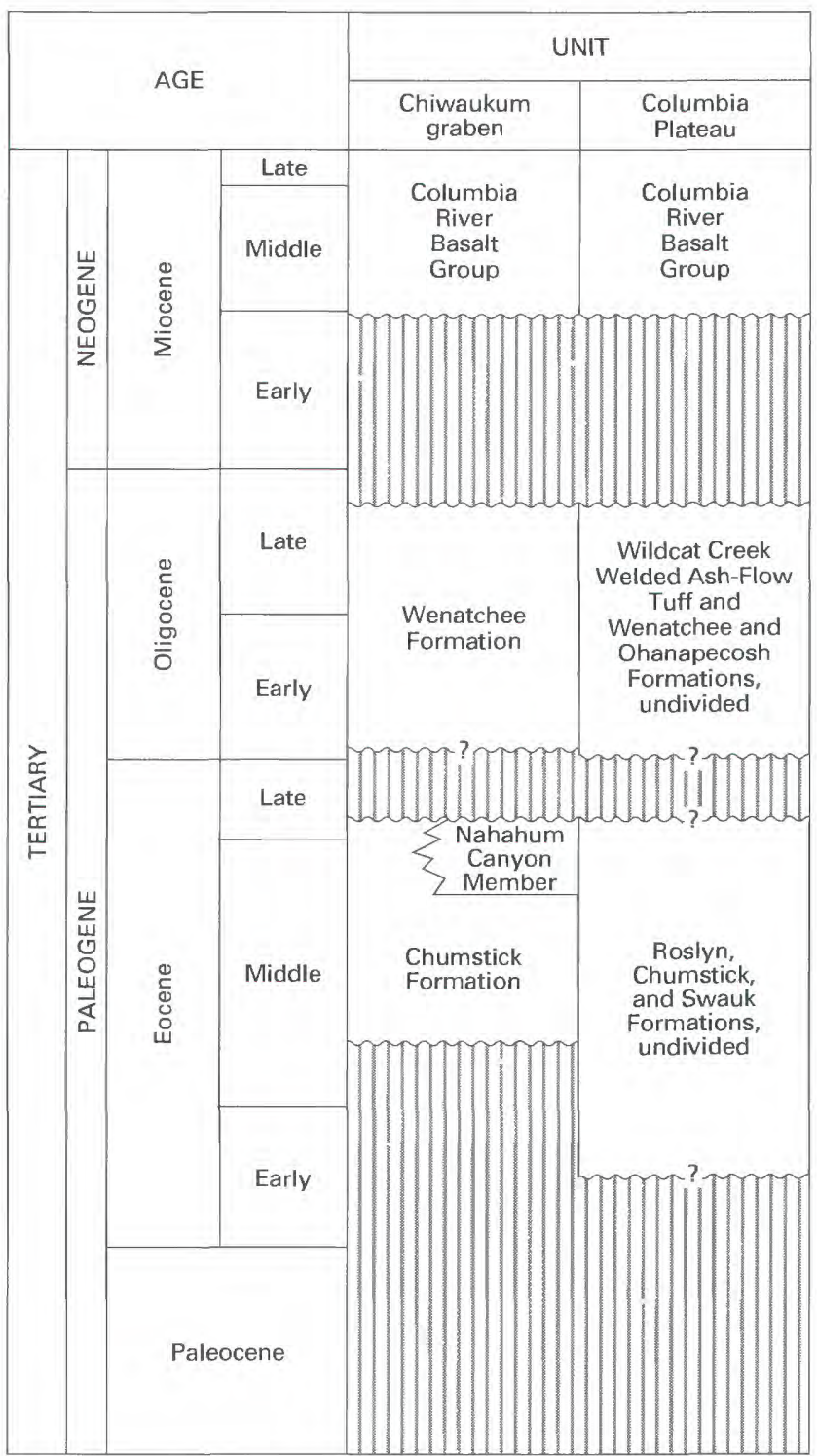

Figure 64. Generalized stratigraphic column, Eastern Oregon-Washington province (081). Vertical line pattern, hiatus. Wavy line, unconformity; queried where position or extent uncertain. 


\section{NORTHWESTERN COLUMBIA PLATEAU PLAY (020)}

This gas play coincides with, and is characterized by the inferred extent, beneath the Miocene Columbia River Basalt Group, of a 4,000-20,000-ft-thick sequence of lower Tertiary fluvial and lacustrine sedimentary rocks, deposited mostly in fault-controlled basins and interbedded with volcanic and volcaniclastic rocks. The boundaries of the play are somewhat conjectural, as they depend on the inferred presence of the sedimentary rocks. The northeastern boundary is the projection of the Entiat fault (the northeastern boundary of the Chiwaukum graben) beneath the basalt. The southwestern margin is the approximate projection of the southeast-trending faults at the south end of the Straight Creek fault. The northern and southern margins are somewhat arbitrary and consist of the northern limit of the basalt and the Columbia River respectively. The play is about $125 \mathrm{mi}$ long and $60 \mathrm{mi}$ wide (fig. 65).

Potential reservoirs are of poor to fair quality. They consist of arkosic fluvial sandstone units of the Eocene Swauk, Chumstick, and Roslyn Formations, and the Oligocene Wenatchee Formation (fig. 64). Marginally adequate porosity (up to about 15 percent) has been reported in sandstone from three of the wells that penetrated this section, although the Chumstick and Wenatchee Formations have excellent porosity and permeability in outcrops near the edge of the basalt. Zeolitization is widespread in outcrops of the Chumstick Formation and probably detracts from permeability in the subsurface as well.

Potential source rocks are lacustrine and fluvial shale units in the Swauk and Chumstick Formations and possibly coal sequences in the Roslyn Formation (fig. 64). Reported total organic carbon values from outcrops are 0-6 percent (up to 17 percent in the coal-bearing Roslyn Formation). Organic matter is mostly Type III. Vitrinite reflectance values $(0.24-1.38)$ in exposed rocks indicate that maturity is probably adequate beneath the basalt, as do data from subsurface samples. Maturation of the most likely source rocks probably took place during Miocene burial by $5,000-13,000 \mathrm{ft}$ of basalt, as suggested by both Lopatin modeling and by the presence of marginally mature sedimentary interbeds in the lower part of the basalt sequence. Gas shows were common in several wells drilled into sub-basalt sedimentary rocks.

Potential traps consist of large, young anticlines involving basalt as well as prebasalt structures. Seals consist of shale interbeds in the fluvial sequences or possibly basalt flows. Drilling depths required to penetrate beneath the basalt range from about 5,000 to $13,000 \mathrm{ft}$.

The only production in the province is from the Rattlesnake Hills field, reservoired in sandstone interbeds in basalt $(700-1,200 \mathrm{ft}$ depth). This field produced about 1.3 BCF of possibly biogenic gas during the 1920's-1940's. Eight deep exploratory wells have been drilled since the 1950's. Several of these were drilled to sub-basalt depths of $6,000-11,000 \mathrm{ft}$ (total depths to $17,518 \mathrm{ft}$ ), proving the presence of at least $11,000 \mathrm{ft}$ of sedimentary rocks. Significant subcommercial shows (5-6 MMCFGPD, and condensate) were encountered in one well; most of the wells had gas shows. The play's future potential for gas is considered to be minor.

OIL AND GAS PLAY DATA

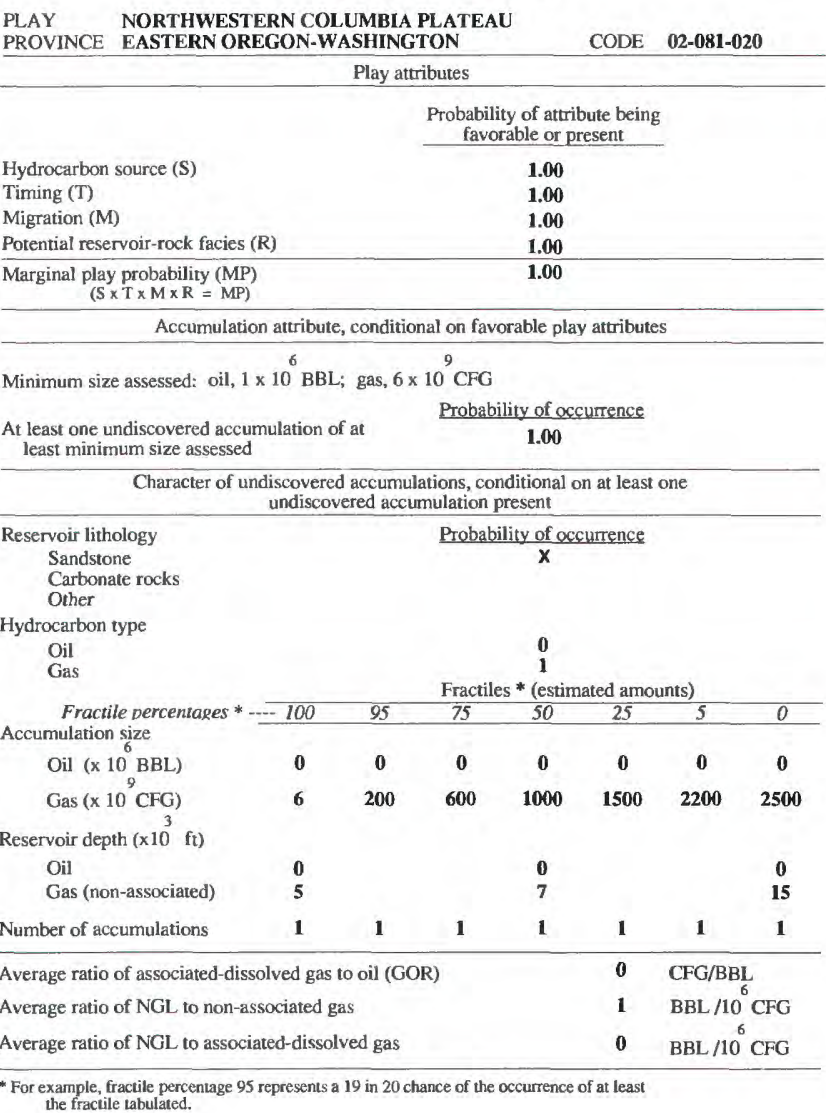


REGION 1, ALASKA; REGION 2, PACIFIC COAST

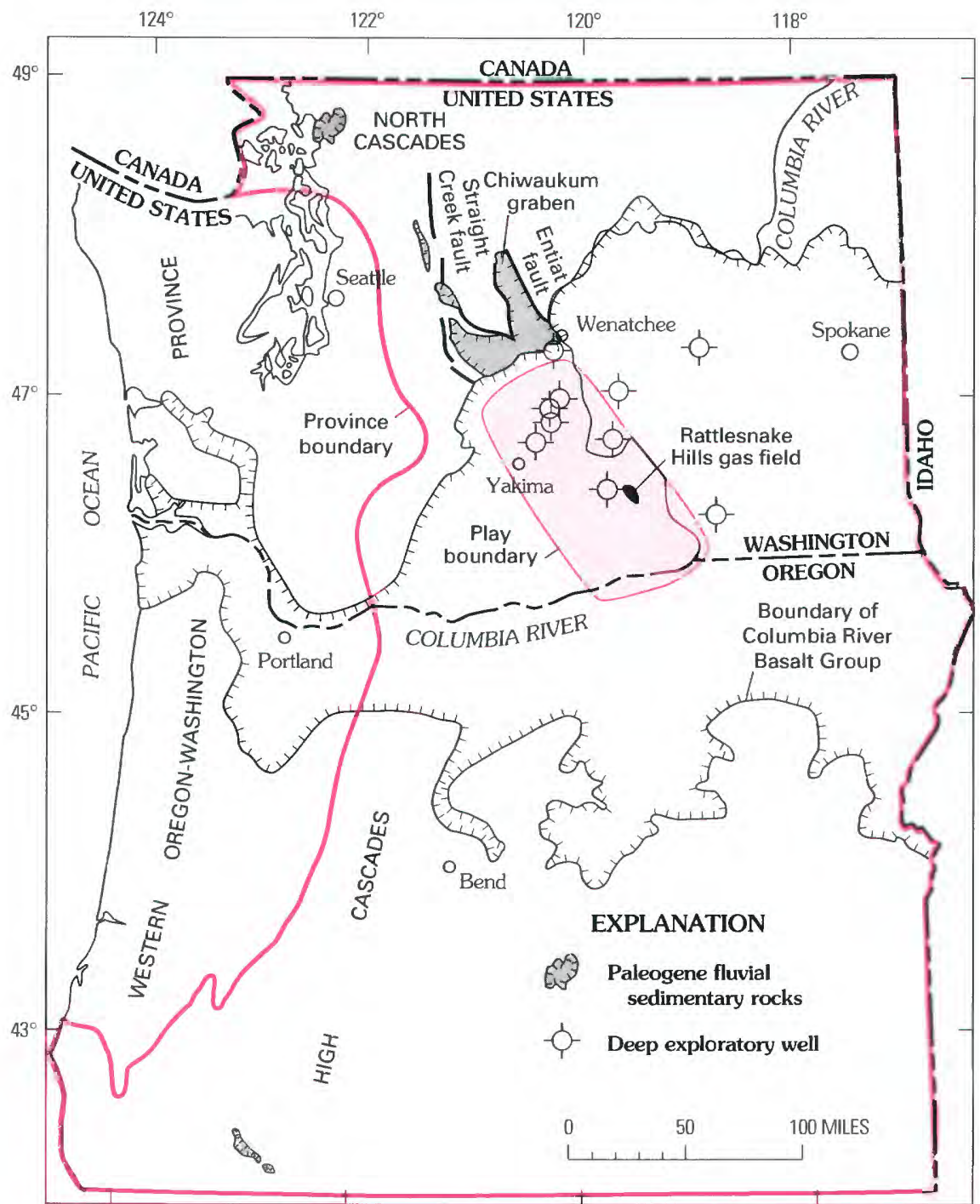

Figure 65. Map of Northwestern Columbia Plateau play (081-020). 


\title{
EASTERN CALIFORNIA PROVINCE (081A)
}

\author{
By Harry E. Cook
}

The province is essentially a composite of nine geomorphic subprovinces encompassing about two-thirds of the State of California (fig. 66). The subprovinces represent a collage of diverse basins and basin types that evolved in response to a number of geologic events. These events ranged from the initial passive-margin rifting and development of the western margin of North America during the late Proterozoic and early Paleozoic, to the basin-and-range structural framework in the Cenozoic. The only hydrocarbon shows reported from abandoned wells occur in three subprovinces, the Cascade Modoc Plateau, Coast Ranges, and Peninsular Range. About 200 wildcat wells have been drilled in these three areas, most of them in the Peninsular Range subprovince. Because of intensive tectonism, plutonic activity, a high degree of metamorphism affecting Paleozoic rocks, and a minimal thickness of Mesozoic strata and limited areas of marine Tertiary rocks, the province is estimated to have a negative future potential for undiscovered oil or gas. Therefore, no plays were defined and no assessment of resources was done. 
REGION 1, ALASKA; REGION 2, PACIFIC COAST

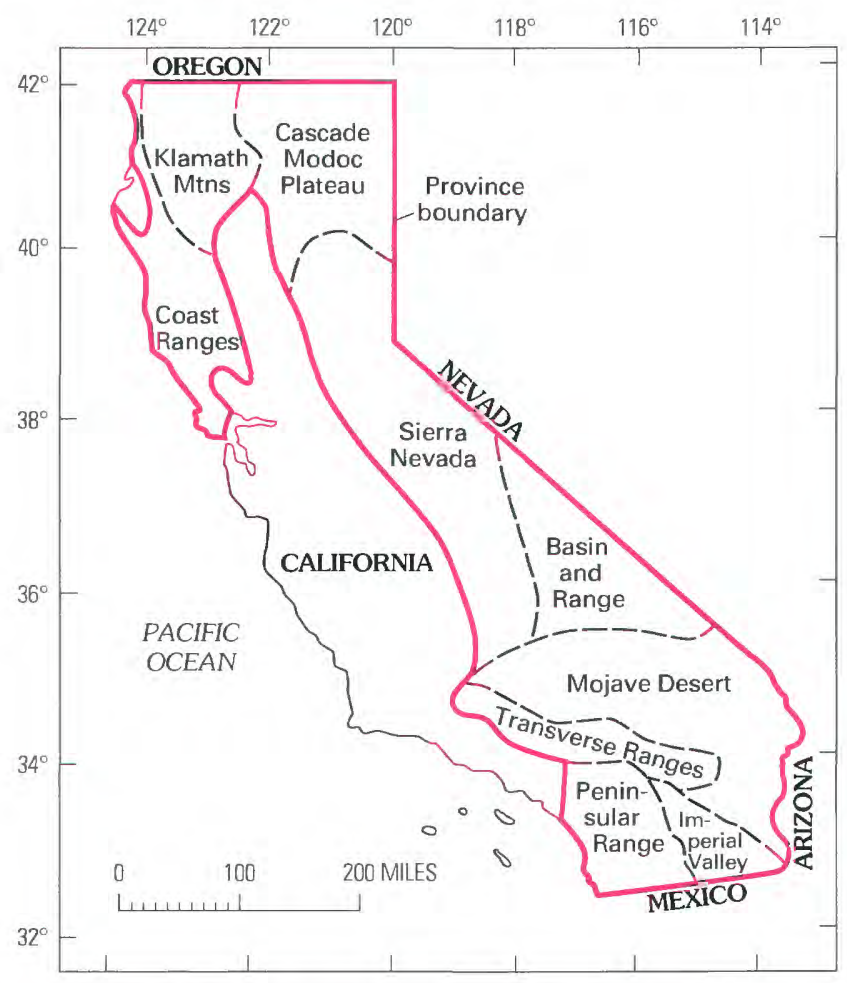

Figure 66. Map of Eastern California province (081A). Dashed line, boundary of subprovince. 


\section{SELECTED REFERENCES}

\section{Region 2. Pacific Coast}

Western Oregon-Washington province (072)

Stanley, R.G., 1991, Geologic basis for petroleum resource assessment of onshore western Oregon and Washington (Province 72): U.S. Geological Survey Open-File Report 88-450-X, 29 p.

Sacramento Basin province (073)

Beyer, L.A., 1989, Summary of geology and petroleum plays used to assess undiscovered petroleum resources of Sacramento Basin Province, California: U.S. Geological Survey Open-File Report $88-450-0,64$ p.

San Joaquin Basin province (074)

Beyer, L.A., and Bartow, J.A., 1988, Petroleum plays and summary of geology and petroleum development used to assess undiscovered recoverable petroleum resources of San Joaquin Province, California: U.S. Geological Survey Open-File Report 87-450-Z, 80 p., 4 plates.

Los Angeles Basin province (075)

Beyer, L.A., 1988, Summary of geology and petroleum plays used to assess undiscovered petroleum resources of Los Angeles Basin Province, California: U.S. Geological Survey Open-File Report $88-450-\mathrm{L}, 62$ p.

Ventura Basin province (076)

Keller, M.A., 1988, Geologic basis for the assessment of undiscovered oil and gas resources of the Ventura basin province, California, 1987 National Assessment: U.S. Geological Survey OpenFile Report 87-450-M, 39 p.

Santa Maria Basin province (077)

Isaacs, C.M., in press, Petroleum geology of the Santa Maria basin, California, as a basis for resource assessment: U.S. Geological Survey Open-File Report 89-450-C.

Central Coastal Basins province (078)

Isaacs, C.M., in press, Petroleum geology of the Central Coastal basins, California, as a basis for resource assessment: U.S. Geological Survey Open-File Report 89-450-D.

Sonoma-Livermore Basin province (079)

McLean, Hugh, 1988, Federal Lands Assessment Program-Sonoma and Livermore Basins, California (Province 79): U.S. Geological Survey Open-File Report 87-450-J, 9 p.

Humboldt Basin province (080)

McLean, Hugh, 1988, Federal Lands Assessment Program-Eel River (Humboldt) Basin, California (Province 80): U.S. Geological Survey Open-File Report 87-450-I, 8 p.

Eastern Oregon-Washington province (081)

Tennyson, M.E., and Parrish, J.T., 1988, Review of geologic framework and hydrocarbon potential of eastern Oregon and Washington: U. S. Geological Survey Open-File Report 87-450-O, 41 p.

Eastern California province (081A)

Cook, H.E., 1988, National Petroleum Assessment-Eastern California (Province 81A): U.S. Geological Survey Open-File Report 87-450-K, 50 p. 
Table 2. Region 2, Pacific Coast-Estimates of undiscovered recoverable conventional oil, gas, and natural gas liquids (NGL) in onshore provinces and adjacent State waters, by play.

[Province and Region totals are given. Mean value totals may not be equal to the sums of the component means because numbers have been independently rounded. Fractile values $\left(F_{95}, F_{5}\right)$ are not additive and represent estimates with a 19 in 20 chance and a 1 in 20 chance, respectively, of at least these tabulated estimates. Gas includes both nonassociated and associated-dissolved gas. Negl., negligible quantity; -, no estimate]

\begin{tabular}{|c|c|c|c|c|c|c|c|c|c|c|}
\hline & \multicolumn{3}{|c|}{$\begin{array}{c}\text { Crude oil } \\
\text { (Millions of barrels) }\end{array}$} & \multicolumn{3}{|c|}{$\begin{array}{c}\text { Total gas } \\
\text { (Billions of cubic feet) }\end{array}$} & \multicolumn{3}{|c|}{$\begin{array}{c}\text { NGL } \\
\text { (Millions of barrels) }\end{array}$} \\
\hline & & $F_{95}$ & $F_{5}$ & Mean & $\overline{F_{95}}$ & $F_{5}$ & Mean & $F_{95}$ & $F_{5}$ & Mean \\
\hline \multicolumn{11}{|c|}{072 Western Oregon-Washington } \\
\hline 020 & Tertiary Gas & 0.0 & 0.0 & 0.0 & 793.5 & $3,979.5$ & $2,003.8$ & 0.0 & 0.0 & 0.0 \\
\hline \multirow[t]{2}{*}{330} & Gas $<6 \mathrm{BCF}$ & 0.0 & 0.0 & 0.0 & 74.9 & 311.4 & 167.8 & 0.0 & 0.0 & 0.0 \\
\hline & Province total & 0.0 & 0.0 & 0.0 & 867.9 & $4,291.1$ & $2,171.6$ & 0.0 & 0.0 & 0.0 \\
\hline \multicolumn{11}{|c|}{073 Sacramento Basin } \\
\hline 020 & Paleocene-Eocene & 0.0 & 0.0 & 0.0 & 158.1 & 735.7 & 380.4 & 0.2 & 0.7 & 0.4 \\
\hline 030 & Starkey-Winters & 0.0 & 0.0 & 0.0 & 292.4 & 984.7 & 574.4 & 0.3 & 1.0 & 0.6 \\
\hline 040 & Guinda-Kione-Forbes & 0.0 & 0.0 & 0.0 & 174.9 & $1,244.0$ & 557.3 & 0.0 & 0.0 & 0.0 \\
\hline \multirow[t]{2}{*}{330} & Gas $<6 \mathrm{BCF}$ & 0.0 & 0.0 & 0.0 & 162.3 & 400.5 & 264.8 & 0.2 & 0.4 & 0.3 \\
\hline & Province total & 0.0 & 0.0 & 0.0 & 763.0 & $3,373.6$ & $1,776.8$ & 0.6 & 2.1 & 1.2 \\
\hline \multicolumn{11}{|c|}{074 San Joaquin Basin } \\
\hline 020 & Southern Post-Miocene & 22.5 & 100.3 & 52.6 & 30.4 & 161.6 & 79.8 & 0.8 & 3.4 & 1.8 \\
\hline 030 & Southwest Upper Miocene & 60.8 & 460.0 & 202.1 & 97.3 & 736.0 & 323.3 & 3.9 & 29.4 & 12.9 \\
\hline \multirow[t]{2}{*}{040} & Miocene Fractured & & & & & & & & & \\
\hline & Diatomaceous & 143.4 & 631.3 & 333.0 & 215.1 & 946.9 & 499.5 & 4.1 & 18.0 & 9.5 \\
\hline 050 & Southeast Eocene-Pleistocene & 41.5 & 230.7 & 112.1 & 20.8 & 115.4 & 56.1 & 0.3 & 1.7 & 0.8 \\
\hline 060 & East Pre-Pliocene & 97.5 & 500.3 & 249.7 & 441.1 & $1,841.1$ & 990.3 & 44.9 & 295.7 & 135.7 \\
\hline 070 & West Pre-Upper Miocene & 172.6 & $1,224.7$ & 549.0 & 362.4 & $2,571.8$ & $1,152.8$ & 24.6 & 174.9 & 78.4 \\
\hline 080 & Northern Pre-Pliocene & 0.8 & 21.4 & 7.9 & 31.9 & 171.9 & 84.4 & Negl. & 0.9 & 0.3 \\
\hline 320 & Oil <1 MMB & 16.3 & 41.5 & 27.1 & 29.3 & 74.8 & 48.7 & 0.0 & 0.0 & 0.0 \\
\hline \multirow[t]{2}{*}{330} & Gas $<6 \mathrm{BCF}$ & 0.0 & 0.0 & 0.0 & 22.2 & 60.6 & 38.4 & 1.1 & 3.0 & 1.9 \\
\hline & Province total & 547.7 & $3,214.7$ & $1,533.4$ & $1,227.0$ & $6,693.2$ & $3,273.2$ & 79.4 & 527.2 & 241.4 \\
\hline \multicolumn{11}{|c|}{075 Los Angeles Basin } \\
\hline 020 & Northwest Shelf & 3.4 & 49.1 & 17.9 & 2.4 & 35.3 & 12.9 & 0.1 & 1.8 & 0.7 \\
\hline 030 & North Flank & 55.2 & 336.5 & 158.5 & 99.4 & 605.7 & 285.4 & 3.3 & 20.0 & 9.4 \\
\hline 040 & Central and Northeast & 171.2 & 984.9 & 473.0 & 171.2 & 984.9 & 473.0 & 12.0 & 68.9 & 33.1 \\
\hline \multirow[t]{2}{*}{320} & Oil <1 MMB & 13.8 & 49.4 & 28.2 & 16.6 & 59.3 & 33.8 & 0.0 & 0.0 & 0.0 \\
\hline & Province total & 241.7 & $1,421.7$ & 677.7 & 287.9 & $1,686.7$ & 805.1 & 15.3 & 90.8 & 43.2 \\
\hline \multicolumn{11}{|c|}{076 Ventura Basin } \\
\hline 020 & Neogene & 122.0 & $1,048.7$ & 442.9 & 219.5 & $1,887.7$ & 797.2 & 10.5 & 90.6 & 38.3 \\
\hline 030 & Paleogene & 70.4 & 546.3 & 237.9 & 153.8 & 941.6 & 442.9 & 4.0 & 24.6 & 11.6 \\
\hline 320 & Oil <1 MMB & 12.1 & 34.5 & 21.5 & 20.5 & 58.6 & 36.5 & 0.0 & 0.0 & 0.0 \\
\hline \multirow[t]{2}{*}{330} & Gas $<6$ BCF & 0.0 & 0.0 & 0.0 & 11.3 & 38.0 & 22.2 & 0.0 & 0.0 & 0.0 \\
\hline & Province total & 202.4 & $1,630.0$ & 702.3 & 398.2 & $2,931.3$ & $1,298.8$ & 14.5 & 115.3 & 49.9 \\
\hline \multicolumn{11}{|c|}{ 077 Santa Maria Basin } \\
\hline 020 & Neogene & 115.4 & 452.5 & 249.1 & 103.8 & 407.3 & 224.2 & 6.2 & 24.4 & 13.5 \\
\hline \multirow[t]{2}{*}{320} & Oil <1 MMB & 11.3 & 38.0 & 22.2 & 10.2 & 34.2 & 20.0 & 0.0 & 0.0 & 0.0 \\
\hline & Province total & 126.6 & 490.6 & 271.3 & 114.0 & 441.5 & 244.2 & 6.2 & 24.4 & 13.5 \\
\hline \multicolumn{11}{|c|}{078 Central Coastal Basins } \\
\hline 020 & Neogene & 48.1 & 703.4 & 256.5 & 38.5 & 562.7 & 205.2 & 1.2 & 16.9 & 6.2 \\
\hline \multirow[t]{2}{*}{320} & Oil <1 MMB & 5.0 & 13.1 & 8.4 & 4.0 & 10.5 & 6.8 & 0.0 & 0.0 & 0.0 \\
\hline & Province total & 51.4 & 718.6 & 265.0 & 41.1 & 574.8 & 212.0 & 1.2 & 16.9 & 6.2 \\
\hline
\end{tabular}


Table 2. Region 2, Pacific Coast-Estimates of undiscovered recoverable conventional oil, gas, and natural gas liquids (NGL) in onshore provinces and adjacent State waters, by play-Continued.

\begin{tabular}{|c|c|c|c|c|c|c|c|c|c|c|}
\hline & & \multicolumn{3}{|c|}{$\begin{array}{c}\text { Crude oil } \\
\text { (Millions of barrels) }\end{array}$} & \multicolumn{3}{|c|}{$\begin{array}{c}\text { Total gas } \\
\text { (Billions of cubic feet) }\end{array}$} & \multicolumn{3}{|c|}{$\begin{array}{c}\text { NGL } \\
\text { (Millions of barrels) }\end{array}$} \\
\hline & & $\mathrm{F}_{95}$ & $F_{5}$ & Mean & $\mathrm{F}_{95}$ & $\mathrm{~F}_{5}$ & Mean & $F_{95}$ & $\mathrm{~F}_{5}$ & Mean \\
\hline \multicolumn{11}{|c|}{079 Sonoma-Livermore Basins } \\
\hline 020 & Livermore Structure & 0.0 & 11.3 & 4.5 & 0.0 & 11.3 & 4.5 & 0.0 & 0.0 & 0.0 \\
\hline \multirow[t]{2}{*}{320} & Oil < 1 MMB & 0.0 & 0.0 & Negl. & 0.0 & 0.0 & 0.0 & 0.0 & 0.0 & 0.0 \\
\hline & Province total & 0.0 & 11.3 & 4.5 & 0.0 & 11.3 & 4.5 & 0.0 & 0.0 & 0.0 \\
\hline \multicolumn{11}{|c|}{080 Humboldt Basin } \\
\hline 020 & Neogene Structure & 0.0 & 0.0 & 0.0 & 0.0 & 97.3 & 26.8 & 0.0 & 0.0 & 0.0 \\
\hline \multirow[t]{2}{*}{330} & Gas $<6$ BCF & 0.0 & 0.0 & 0.0 & 4.4 & 12.8 & 8.0 & 0.0 & 0.0 & 0.0 \\
\hline & Province total & 0.0 & 0.0 & 0.0 & 5.1 & 102.8 & 34.7 & 0.0 & 0.0 & 0.0 \\
\hline \multicolumn{11}{|c|}{081 Eastern Oregon-Washington } \\
\hline 020 & Northwestern Columbia Plateau & 0.0 & 0.0 & 0.0 & 392.1 & $2,261.3$ & $1,085.2$ & 0.4 & 2.3 & 1.1 \\
\hline \multirow[t]{2}{*}{330} & Gas $<6 \mathrm{BCF}$ & 0.0 & 0.0 & 0.0 & 35.5 & 130.9 & 73.8 & 0.0 & 0.0 & 0.0 \\
\hline & Province total & 0.0 & 0.0 & 0.0 & 426.4 & $2,392.9$ & $1,159.0$ & 0.4 & 2.3 & 1.1 \\
\hline \multicolumn{2}{|c|}{ 081A Eastern California } & - & - & - & - & - & - & - & - & - \\
\hline & REGION TOTAL & $1,499.4$ & $6,609.5$ & $3,484.9$ & $5,462.7$ & $19,182.0$ & $11,010.5$ & 138.4 & 721.9 & 358.5 \\
\hline
\end{tabular}





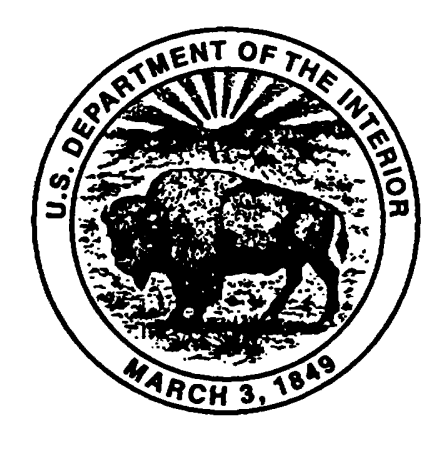

